BUDAPESTI CORVINUS EGYETEM

KÖZGAZDASÁGTUDOMÁNYI DOKTORI ISKOLA

Keresztély Tibor

\title{
AZ EU-TRANSZFEREK FELHASZNÁLÁSÁNAK EREDMÉNYESSÉGE ÉS MAKROGAZDASÁGI HATÁSAI
}

PhD értekezés

Budapest, 2013. február 


\section{Tartalomjegyzék}

BEVEZETÉS 3

1 AZ EU-TRANSZFEREK SZERKEZETE ÉS KÖZVETLEN MAKROGAZDASÁGI HATÁSAI .. 10

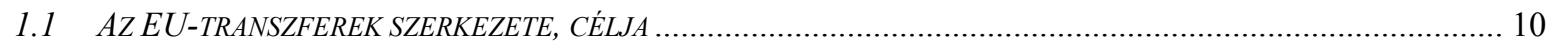

1.2 A MAGYARORSZÁGRA ÉRKEZŐ TRANSZFEREK VÁRHATÓ SZERKEZETE …………………………………..... 12

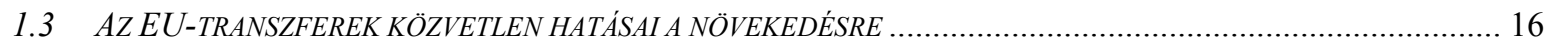

2 AZ EU-TRANSZFEREK MAKROGAZDASÁGI HATÁSVIZSGÁLATÁNAK NEMZETKÖZI ÉS

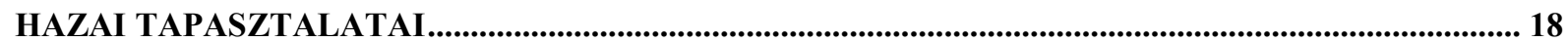

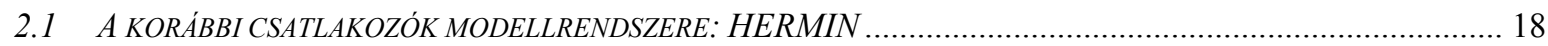

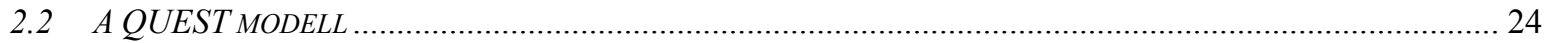

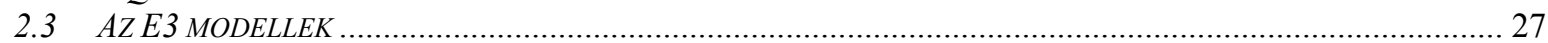

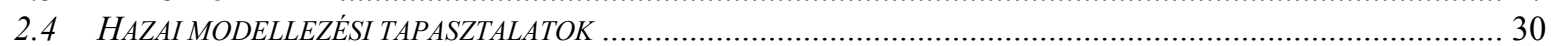

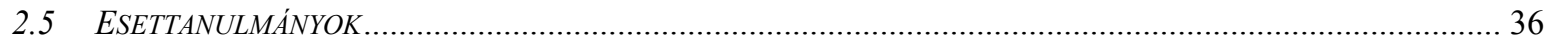

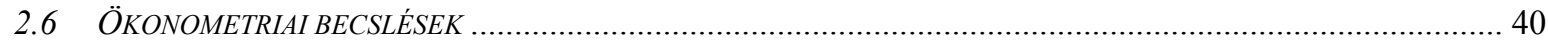

3 HOSSZÚ TÁVÚ MODELLEK ELMÉLETI ALAPJAI ÉS A NEMZETKÖZI MODELLÉPÍTÉSI

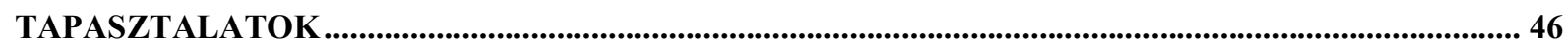

3.1 AZ ENDOGÉN NÖVEKEDÉSI ELMÉLETEK HELYE A KÖZGAZDASÁGI ELMÉLETEK TÖRTÉNETÉBEN …….............. 47

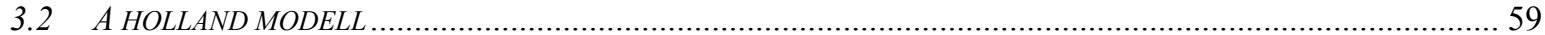

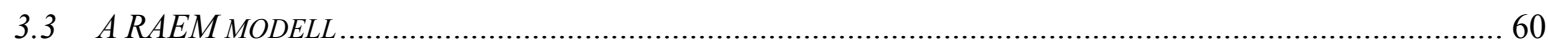

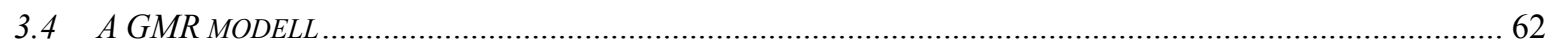

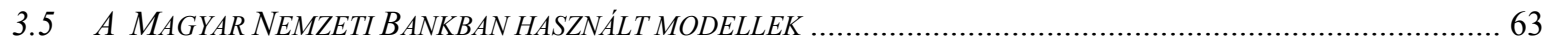

4 A HATÁSVIZSGÁLATHOZ ALKALMAZOTT MODELL BEMUTATÁSA........................................... 66

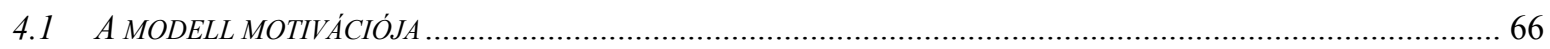

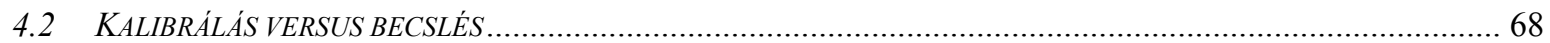

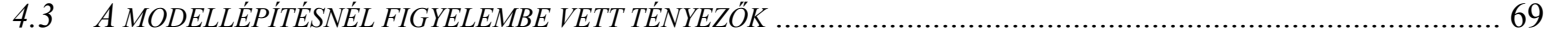

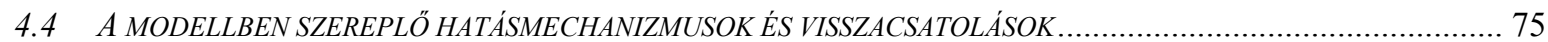

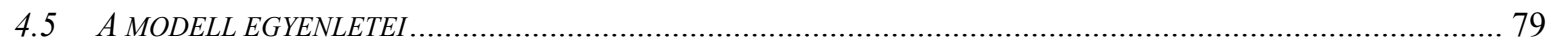

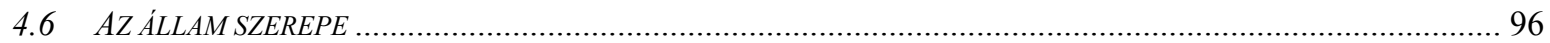

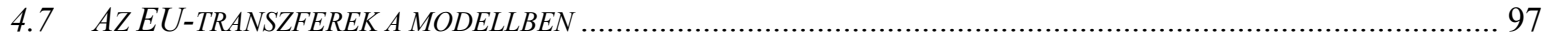

5 AZ EU-TRANSZFEREK FELHASZNÁLÁSI SZERKEZETÉNEK MAKROGAZDASÁGI

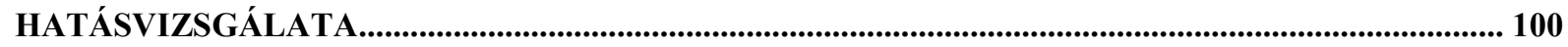

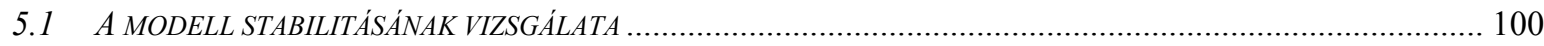

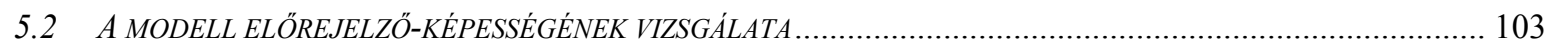

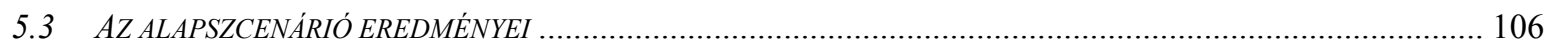

5.4 A „HATÉKONYABB KIADÁSI SZERKEZET” SZCENÁRIÓ FELTÉTELRENDSZERE ÉS EREDMÉNYEI....................... 118

$5.5 \quad A$,KEVESEBB EU-FORRÁS” SZCENÁRIÓ FELTÉTELRENDSZERE ÉS EREDMÉNYEI ...................................... 120

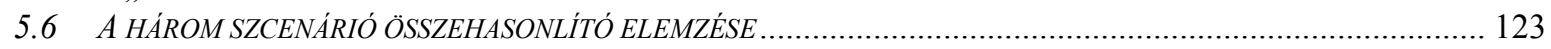

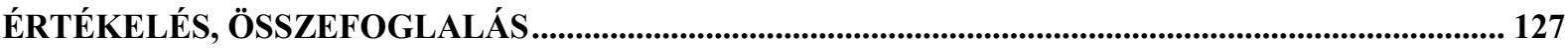

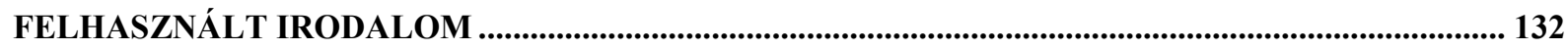

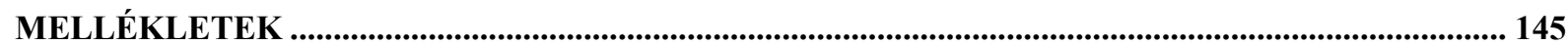




\section{Bevezetés}

Az EU csatlakozás egyik nagy reményekkel várt eredménye volt az EU támogatási csatornáinak megnyílása az új tagállamok felé. Bár a 2004-ben taggá vált országok esetében jelentős eltérés mutatkozott a transzferek mennyiségében illetve a GDP-hez viszonyított arányában, egyöntetü volt a vélemény, miszerint ezek a pénzek jelentősen hozzájárulhatnak a közlekedési és humán infrastruktúra valamint az állami intézményrendszer fejlesztéséhez, és általában is elősegítheti gazdasági fejlődést, gyorsíthatja az érintett országok felzárkózását.

Egyre fontosabbá válik az a kérdés, hogy az EU által nyújtott támogatások mekkora szerepet játszanak a tagállamok felzárkózási folyamatában, mennyiben járulnak hozzá a gazdasági növekedéshez. Ennek a kérdésnek igen nagy jelentősége van Magyarország szempontjából is, hiszen a csatlakozás óta jelentős mértékű uniós forrásban részesülünk, amely - megfelelő felhasználás esetén - segíthet egy magasabb növekedési pályára lépésben, elősegítheti a felzárkózást a fejlettebb EU tagállamokhoz. Mindez azért is kiemelkedő jelentőségű, mert a rendszerváltás után két évtizeddel Magyarországon még mindig meglehetősen alacsony szintü tőke akkumulációja, így a hazai gazdaság tartósan rá van szorulva a külső forrásokra. Fontos tehát a rendelkezésre álló szűkös erőforrások hatékony elosztása, ami eddig sajnálatos módon nem volt erőssége a magyar gazdaságpolitikának. Ebből a szempontból lakmuszpapírként tekinthetünk az uniós transzferekre, ugyanis ha sikerül megfelelnünk a felhasználással kapcsolatos szigorú elvárásoknak, vagyis nagy arányban tudjuk lehívni és képesek vagyunk hatékonyan elkölteni ezeket az összegeket, akkor reménykedhetünk abban, hogy általánosságban is javul a beruházási döntések hatékonysága és átláthatósága.

Az Európai Uniótól kapott támogatások számos csatornán keresztül befolyásolhatják egy ország hosszú távú gazdasági növekedését. A pénzügyi támogatások keresletnövelő hatása ösztönzi a gazdaságot, a fizikai infrastruktúra javítása ösztönzi a kereskedelmet, vonzza a beruházásokat, ezáltal a gazdasági hatékonyság emelkedik. Az EU-tól kapott tőketranszferek bővítik a beruházásokat, növelik a vállalkozások versenyképességét, ezáltal a GDPnövekedésre is ösztönzőleg hatnak. A humántőke fejlesztését szolgáló programok növelik a foglalkoztatást, ami önmagában nagyobb hozzáadott-értéket eredményez, továbbá ezzel együtt növekszik a vásárlóerő is, ami tovább élénkíti a gazdaságot. A kutatásra és fejlesztésre, valamint az információtechnológiára adott támogatások hosszabb távon eredményezik a 
versenyképesség javulását. A támogatások nagyságán túl az optimális felhasználási szerkezetnek legalább akkora szerepe lehet a felzárkózás elősegítésében, vagyis hogy megfelelő mértékben fordítják-e produktív területekre, mint például a kutatás-fejlesztésre és a humántőke támogatására.

Dolgozatom fó célja, hogy választ kapjunk arra a kérdésre, mennyiben segítik az Európai Uniótól kapott támogatások egy ország gazdasági fejlődését, illetve javítja-e Magyarország felzárkózási esélyeit a felhasznált transzferek összegének növekedése és a támogatások összetételének átalakítása. Kutatási hipotézisem értelemszerüen az volt, hogy létezik ilyen hatás, azaz a ténylegesen lehívott EU-transzferek mennyisége illetve azok szerkezete befolyásolja a növekedési pályát. Eredményeim megerősítik ezt a feltételezést, ugyanakkor a hatás mértéke valamivel kisebb az általam előzetesen reméltnél.

Célom volt az is, hogy a fenti kérdésre adott válasz egy arra alkalmas modellel végzett számítások eredményeként szülessen meg. Az említett hatások modellezéséhez az endogén növekedési elméletek kínálják a legmegfelelöbb keretet, azokban ugyanis épp az EUtranszferek által érintett tényezők jelentik a technológiai haladás és a humántőke növekedésének legfontosabb magyarázó változóit.

Az endogén növekedéselméletek a 80-as években jelentek meg, és főként a solow-i modell azon feltételezésének kritikájaként fogalmazódtak meg, miszerint a technikai fejlődés külső adottságként jelenik meg a gazdaság számára. Romer [1986] ezt olyannyira tagadja, hogy bevezeti a „technológiai közgazdaságtan” fogalmát, ${ }^{1}$ melynek fókuszában olyan fogalmak állnak, mint a beruházás, az innováció és a humántőke. Romer szerint ugyanis elsősorban ezek a tényezők határozzák meg a gazdasági növekedés lehetőségeit. Mindehhez azt is hozzáteszi, hogy a kibocsátás a tőkének nem csökkenő, hanem növekvő hozadékú függvénye.

Az egzogén növekedési modellekkel szemben megfogalmazott legfontosabb kritika, hogy nem magyarázzák az országok közti fejlettségbeli különbségeket, vagyis a tartósan eltérő növekedési ütem forrását. Az endogén növekedési modellek ezzel szemben a technológiai fejlődést endogenizálják, ebben az új keretben ugyanis bizonyos gazdaságpolitikai intézkedések (például $\mathrm{K}+\mathrm{F}$, vagy humántőke támogatása) befolyásolják a gazdaság hosszú

\footnotetext{
${ }^{1}$ Lásd még: Móczár [2008]
} 
távú növekedési rátáját. Romer szerint a neoklasszikus modell másik gyenge pontja, hogy csak az eltérő egyensúlyi pályákon való haladást képes kezelni, így nem tud magyarázatot adni arra, hogy az egyik pályáról hogyan tér át a gazdaság a másikra. Erre szintén megoldást ad az új modell a folyamatos technikai fejlődés középpontba állításával. A növekedésnek ez a magyarázata tehát nem egyensúlyi megközelítés, hanem arra keres magyarázatot, hogy a gazdaság hogyan viselkedik ezen egyensúlyi állapotok között. Ennek a megközelítésnek egyik legnagyobb előnye, hogy ezáltal modellezhetőek a gazdaságot érő sokkok és a gazdaságpolitikai intézkedések hatásai. ${ }^{2}$

Az endogén modellek egyik legismertebbje Rebelo [1991] AK-modellje. Rebelo egyrészt állandó skálahozadékot feltételez, másrészt a tőkeállományt tágan értelmezi, mind a fizikai, mind a humántőkét tartalmazza. Eszerint a tőkeállomány állandó ütemben növekszik, és a gazdaság növekedési ütemének nagysága egyenesen arányos a megtakarítási ráta és a termelésiszint-tényező nagyságával, illetve fordítottan arányos a népességnövekedési ütemmel. Ebből következően létezhet a gazdaságoknak hosszú távon pozitív növekedési üteme, valamint nem szükségszerü, hogy a gazdaságok azonos növekedési ütemhez tartsanak. Azért sem valósul meg abszolút konvergencia, mert ha a skálahozadék konstans, akkor a fenti egyenlőségből zéró konvergencia adódik.

Romer ezzel szemben a termelésben növekvő skálahozadékot feltételez. A növekvő hozadék azonban csak a gazdaság egészére jellemző, az egyes vállalatok továbbra is csökkenő hozadék mellett termelnek. A termelési függvényben kétfajta tőkeállományt különít el, az egyik a vállalat döntései által befolyásolható saját tőkeállomány, a másik pedig kívülről adott aggregált tőkeállományt jelent, amelyet önmagában egyetlen vállalat sem képes befolyásolni. Ez utóbbi nagyságát olyan tényezők befolyásolják, mint a humántőkével vagy az információval való ellátottság mértéke a gazdaságban. Minél nagyobb ezen aggregált tőkeállomány nagysága, annál több vállalat müködhet a piacon, annál könnyebben terjed el egy technológiai újítás és annál hatékonyabban képesek az egyes termelők működtetni saját vállalatukat. Romer ennek elsődleges forrásaként a kutatás-fejlesztést jelöli meg. Egyetlen vállalat számára azonban a $\mathrm{K}+\mathrm{F}$ beruházások csökkenő hozadékúak a termelésre vonatkozóan. Mivel azonban az új találmányok „fogyasztásából” senki nem zárható ki, ezért ezek pozitív externális forrást jelentenek a többi vállalat számára. Romer szerint mindezek

\footnotetext{
${ }^{2}$ Az endogén növekedéselméletről részletesebben lásd még: Aghion - Howitt [1998] vagy Meyer [1995]
} 
következtében a tőkeállomány növekedésével a beruházási ráta és a tőkemegtérülési ráta is növekszik, így nem szükségszerü a gazdasági konvergencia bekövetkezése, sőt a fejlett gazdaságok akár hosszabb távon is gyorsabban növekedhetnek, mint a kevésbé fejlettek.

Az endogén növekedési elmélet másik alapkövének Lucas [1988] munkája tekinthető. Ö veti fel azt a problémát a neoklasszikus modellel kapcsolatban, hogy a felzárkózás már csak azért sem következik be automatikusan, mert a neoklasszikus elmélettel szemben a tényezőárak nem egyenlítődnek ki, így a tőke nem áramlik feltétlenül a fejlett országokból a fejletlenekbe. Utóbbit azzal is magyarázza, hogy a fejlett országok humántőkében gazdagabbak, azaz munkásaik képzettebbek, mint a fejletlen országokéi. Ennek következtében ugyanis akár el is tünheta fejlett és kevésbé fejlett gazdaságok tőkemegtérülési rátája közötti különbség.

Lucasnál jelenik meg először az úgynevezett Teljes Tényező Termelékenység (Total Factor Productivity, TFP) fogalma. A TFP lényegében a Cobb-Douglas termelési függvényben szereplő szorzótényező: ${ }^{3}$

$$
Y=T F P \cdot K^{\alpha} \cdot L^{1-\alpha}
$$

Ebben a megközelítésben az endogén növekedéselmélet a TFP alakulását magyarázza. Eszerint a technikai fejlettséget részben meghatározó TFP növekedéséért jelentős részben az állam felelős. Ez alatt azt értjük, hogy a kormány gazdaságpolitikája mennyire támogatja a technikai haladást, azaz fejleszti-e kellőképpen a fizikai és humán infrastruktúrát, valamint az oktatást, segíti-e a kutatást-fejlesztést. Ha igen, akkor a TFP gyorsabban növekedhet, ekkor tehát erőteljesebb endogén technikai fejlődésről beszélünk.

Az endogén növekedéselmélet megjelenése óta már elég idő telt el ahhoz, hogy mértéktartó gyakorlati eredmények is szülessenek a témában. Jones [1995] szerint az elméletből az következne, hogy permanens gazdaságpolitikai változások esetén a GDP növekedési ütemének is permanensen kellene változnia. Ezzel szemben az amerikai gazdaság adatait elemezve arra az eredményre jut, hogy például a beruházási ráta tartós megemelkedése nincs hatással a hosszú távú növekedésre. Következtetéseiben általánosságban is kritizálja a növekedési modelleket, és kijelenti, hogy csak azok a modellek tekinthetők megfelelőnek,

\footnotetext{
${ }^{3}$ Lucas eredetileg a humántőkét a munka szorzótényezőjeként szerepeltette, lényegében úgy tekintette, mint egy olyan tényezőt, amely növeli az effektív munkafelhasználást. Az újabb megközelítésekben a humántőke egyre gyakrabban a TFP-ben jelenik meg.
} 
amelyekben olyan mechanizmusok szerepelnek, amelyek magyarázatul szolgálnak a vártnál kisebb elmozdulásokra. Li [2002] újra megvizsgálta, hogy hat-e az amerikai beruházási ráta a hosszú távú növekedésre, és Jonesszal ellentétben azt az eredményt kapta, hogy szignifikánsan javítja a növekedési kilátásokat a beruházások tartós megemelkedése.

Barro és Sala-i-Martin [1995] egy egész könyvet szentel a gazdasági növekedés témakörének. Művükben részletesen bemutatják az endogén növekedési modellek különböző változatait, majd számos becslési eredményt közölnek. Megállapítják, hogy a világ mindhárom fejlett régiójában hosszú távon egyaránt érvényesül a béta és a szigma konvergencia is. Előbbi a fejletlenebb régiók illetve tagállamok fokozatos felzárkózását, utóbbi a valamennyi régió között mért szóródás csökkenését jelenti. Fontos tanulság, hogy a válságok általában átmenetileg megakasztják a konvergencia folyamatokat, ugyanakkor a hosszú távú folyamatokra ritkán vannak hatással. Erre példa az 1973-as olajársokk, aminek hatására az Egyesült Államokban és az Európai Unióban is újra növekedni kezdtek a regionális különbségek. Speciális a helyzete Japánnak, ahol a 30-as években érvényesült ugyan a béta konvergencia, viszont az erőteljes fegyverkezési program következtében a prefektúrák fejlettségi szintje között mért szóródás jelentősen növekedett. A központi források jelentős része ugyanis ekkoriban abba a néhány régióba irányult, amelyek jelentős hadipari potenciállal bírtak. A második világháborút követően minden magváltozott, Japán aktív és sikeres gazdaságfejlesztési programot valósított meg, az erre szánt pénzek hatékony elosztása gyors konvergenciát és több évtizedes prosperitást eredményezett. Az Egyesült Államokban az 1960-as évektől léteznek olyan szövetségi transzferek, amelyekkel kifejezetten a kevésbé fejlett tagállamokat támogatják. A szerzőpáros modellszámításai során arra az eredményre jutott, hogy ezen támogatások érdemben javították a szigma konvergenciát, vagyis nélkülük nagyobbak lennének az államok közötti különbségek. Barro és Sala-i-Martin eredményei a saját kérdésfelvetésem szempontjából is értelmezhetőek, hiszen azt mutatják, hogy az aktív közösségi politika segítheti a kevésbé fejlett térségek felzárkózását.

Krugman [1991] a gazdasági fejlődés regionális vetületeit helyezi előtérbe. Elmélete szerint egy adott gazdasági egységen ${ }^{4}$ belül bizonyos körülmények között ${ }^{5}$ automatikusan kialakul

\footnotetext{
${ }^{4}$ Ez lehet kis ország, nagy ország vagy akár makrorégió (pl. EU).

5 Ezek a feltételek elsősorban a tényezőárakra, a regionális piac méretére és a versenyhelyzetre vonatkoznak.
} 
egy fejlettebb és egy fejletlenebb régió. Az amerikai helyzetnek megfelelően Krugman az elöbbit északnak, utóbbit délnek nevezi, de gyakran találkozhatunk a központ és periféria megnevezésekkel, ami inkább az európai viszonyokkal adekvát. Meyer [2005] felhívja a figyelmet, hogy Krugman rendszerében akár csekély elmozdulások is elegendőek lehetnek a feltételrendszerben ahhoz, hogy a divergenciát konvergencia váltsa fel. Vagyis ahogy mintegy magától kialakult a fejlett és fejletlen régió, ugyanúgy visszájára is fordulhat ez a folyamat. Mivel el kell fogadnunk azt a tényt, hogy Magyarország az EU-n belül perifériának minősül, a hazai gazdaságpolitika kiemelt céljai között kell szerepelnie annak, hogy az említett feltételek kedvező irányba változzanak, és folytatódhasson a magyar gazdaság felzárkózása. Ebben az értelemben az általam alkalmazott modell is tartalmaz regionális elemeket: egyrészt elfogadja a magyar gazdaság perifériális jellegét, másrészt az egyenletek között hangsúlyosan jelennek meg a tényezőárak, utóbbiakat Krugman is kiemelten kezeli.

Kuznets [1955] és Williamson [1965] az országokon belüli regionális egyenlőtlenségekre fókuszálnak, és hangsúlyozzák, hogy a felzárkózás kezdeti szakaszában általában növekednek a régiók közötti különbségek. A későbbiekben már fontos cél lehet a regionális differenciák csökkentése, azonban a kezdeti stádiumban ez a törekvés visszavetheti a gazdasági növekedést, lelassíthatja a felzárkózási folyamatot. Az újonnan csatlakozott EU tagállamok többsége az uniós átlaghoz történő felzárkózási pályájának kezdetén tart, így a megfontolt regionális politikának fontos szerepe van a sikeres gazdasági felzárkózásukban.

Az endogén növekedéselméletek tehát feloldják azt a feltevést, hogy a hosszú távú egyensúlyi növekedési pályának a meredekségét egzogén módon csak a technikai haladás befolyásolja. Ehelyett a technikai haladás is endogén módon jelenik meg. Különböző elméletek másnak a függvényeként fejezik ezt ki, de azzal, hogy megnyílik a lehetőség a fejlődés elősegítésére, új helyzet áll elő. Míg a neoklasszikus elméletnél a gazdaságpolitikának nem volt kiemelkedő szerepe a gazdasági fejlődésben - elsősorban az intézményi keretek megteremtése volt a legfontosabb cél, - az endogén növekedéselméletek alapján viszont már befolyásolható a hosszú távú növekedési ütem is.

Az előzőekben áttekintett endogén növekedési modellek a technikai haladásra helyezik a hangsúlyt a hosszú távú gazdasági növekedés magyarázatában, vagyis a kutatás-fejlesztés és infrastruktúra fejlesztése, támogatása a hosszú távú felzárkózás alapja. Így ennek alapján elmondható, hogy az EU-transzferek, mivel alapvetően ezeket a területeket célozzák meg, 
jelentős mértékben hozzájárulhatnak a gazdasági növekedéshez, gyorsíthatják a felzárkózási folyamatot. Ezért éreztem fontosnak, hogy a dolgozatomban ezt a kérdéskört járjam körül, hiszen hazai viszonylatban óriási összegekről van szó, így nagyon értékes információforrást jelenthetnek a témával kapcsolatos empirikus eredmények.

Disszertációm felépítése a következő. A bevezetést követően rövid elméleti áttekintés következik arról, hogy milyen csatornákon keresztül hathatnak az EU-transzferek a hosszú távú növekedésre. Ebben a fejezetben tekintem át az Európai Unió támogatási rendszerét is, szó lesz továbbá a Kohéziós és Strukturális Alapok szerkezetéröl, céljairól, alapvető jellemzőiröl. Külön hangsúlyt fektettem a magyar vonatkozásokra, a következő programozási időszakra vonatkozó magyarországi célkitüzések és intézkedések bemutatásával. A második fejezet a EU-transzferek makrogazdasági hatásvizsgálatával kapcsolatos irodalmat dolgozza fel. Ezek közül az egyik irány makrogazdasági modellek segítségével próbálja számszerüsíteni a különböző hatásokat. Az értékelési technikák másik csoportja ennél egyszerübb módszertant alkalmazva ökonometriai becslésekkel illetve esettanulmányokkal igyekszik megválaszolni ugyanezt a kérdést. A két módszer egymás mellett és egymást kiegészítve létezik, sok esetben ugyanis egy néhány egyenletes modell célzottabb és pontosabb eredményt ad, mint a sokegyenletes makromodellek. A disszertáció második fele saját eredményeket tartalmaz, melyek alapja egy hosszú távú makroökonómiai modell. Ezért a dolgozat harmadik fejezete az ezzel kapcsolatos tapasztalatokba enged bepillantást. A következő fejezet tartalmazza az alkalmazott modell leírását, melyet az ötödik fejezetben a modell elörejelző-képességének empirikus elemzése és a szcenárióelemzés eredményei követnek. Először az alapváltozatot mutatom be, melyet egy reális makropályának tekintek. A külső és belső feltételrendszer megváltoztatásával alakulnak ki az alternatív makropályák, amelyek elemzésével közelebb kerülünk az EU-transzferek makragazdasági hatásainak megértéséhez. Végül a disszertációm végén összefoglalom a főbb kutatási eredményeimet. 


\section{Az EU-transzferek szerkezete és közvetlen makrogazdasági hatásai}

\subsection{Az EU-transzferek szerkezete, célja}

Az EU egyik kiemelt célja a tagországok gazdasági fejlődésének elösegítése, valamint a kevésbé fejlett régiók, tagországok felzárkózásának támogatása, az eltérő fejlettségi szintek kiegyenlítése - ezáltal a gazdasági és társadalmi kohézió erősítése. A kohéziós politika számára 2007-töl rendelkezésre álló pénzügyi eszközök a strukturális alapok (az Európai Regionális Fejlesztési Alap és az Európai Szociális Alap) és a Kohéziós Alap, melyek működtetése során tőketranszfereket nyújt az előbb említett célok eléréséhez. Az ezt megelőző időszakban a Strukturális Alapokon és a Kohéziós Alapon túl a közösségi kezdeményezések is rendelkezésre álltak a regionális politika eszközeiként. További változás, hogy 2007-ig a Strukturális Alapokon belül müködtek a közös agrárpolitikához, illetve a közös halászati politikához kapcsolódó finanszírozási eszközök is, melyek azonban leválasztásra kerültek és létrejött az Európai Mezőgazdasági és Vidékfejlesztési Alap, valamint az Európai Halászati Alap.

Az alapok két fő csoportjának jellege és célja hasonló, azonban különböznek abban, hogy míg a strukturális alapokat regionális szinten osztják szét, addig a kohéziós alapokból tagországok részesülhetnek. A strukturális alapok továbbá nem különálló projekteket támogatnak, hanem regionális szintü, összetettebb programrendszereket finanszíroznak, a kohéziós alapokból pedig van lehetöség egy-egy önálló - általában infrastrukturális vagy környezetvédelmi projekt finanszírozására. További eltérés figyelhető meg a finanszírozás szerkezetében is: a strukturális alapok esetében a társfinanszírozásnak sokkal nagyobb szerepe van, mint a kohéziós alapoknál, vagyis a támogatásban részesülő régiónak vagy tagországnak magának is hozzá kell járulnia bizonyos mértékü önrésszel az adott program megvalósításához. Ez a sajátrész-arány korábban a strukturális alapok esetében általában 30-50 százalék körül alakult, míg a kohéziós alapoknál minimum 20 százalék volt. A következö, 2007-2013-as programozási időszakban ez kis mértékben megváltozik, mindkét támogatási forma esetében 15 százalékra csökken a minimális saját hozzájárulás, azonban a konkrét értékek programonként eltérőek lehetnek. 
A társfinanszírozáshoz kapcsolódóan érdemes megemlíteni az addicionalitás elvét, amely elöírja, hogy milyen minimális szintü, nem uniós forrásból megvalósítandó állami, fejlesztési beruházásokat szükséges megvalósítania az adott tagállamnak, ezáltal biztosítja, hogy az uniós források ne szorítsák ki az adott tagország egyéb állami beruházásait. Ennek kezelését 2007-től nagymértékben szigorítják, ugyanis ettől kezdve az addicionalitási kiadási célok nem teljesítése esetében a fogadó ország köteles a költségvetési periódust követően a kapott uniós támogatásokat visszafizetni.

Az előző, 2000-2006-os kohéziós politikai program keretében több mint 250 milliárd euró értékü támogatást (1999-es árakon számolva) nyújtottak három támogatási forma keretében: Strukturális Alapok, Kohéziós Alap és a Közösségi kezdeményezések [IBO, 2001]. ${ }^{6}$ Ezek közül a legnagyobb költségvetéssel rendelkező támogatási forma a Strukturális Alapok, amely 195 milliárd eurót biztosított a támogatások finanszírozására.

Ebben a programozási időszakban a strukturális alapoknak három célkitüzésük volt, melyek közül az egyik a fejlődésben elmaradott régiók támogatása, strukturális átalakulásának elősegítése (azok a régiók jogosultak, ahol az egy főre jutó vásárlóerő-paritáson mért GDP nem éri el az uniós átlag 75 százalékát). A Strukturális Alapok teljes összegének 70 százaléka ennek az első célkitűzésnek a teljesülését segítette elő. A második célkitűzés a strukturális problémákkal, gazdasági és szociális átalakulás nehézségeivel küzdő területek esetében a gazdasági és társadalmi átmenet elősegítése. A harmadik célzott terület pedig a foglalkoztatási, oktatási és szakképesítési rendszereket modernizáló programok támogatása volt.

A Kohéziós Alap létrehozásáról a Maastrichti Szerződés rendelkezett, a Közösség legelmaradottabb tagállamainak felzárkózását támogatja a monetáris unióra történő felkészülés időszakában. Célkitüzése a gazdasági és társadalmi kohézió erősítése, és a különböző régiók közti fejlettségbeli különbségek csökkentése. A kohéziós alapokból származó forrásokra azon EU tagországok jogosultak, ahol vásárlóerő-paritáson számított egy főre eső GNP nem éri el a közösségi átlag 90 százalékát.

\footnotetext{
${ }^{6}$ A tanulmány letölthető az Európai Bizottság hivatalos honlapjáról.
} 
A 2007-2013 közötti időszakban az Európai Regionális Fejlesztési Alap, az Európai Szociális Alap és a Kohéziós Alap három új célkitűzéshez járul hozzá7. A konvergencia célkitüzés hasonló a 2002-2006-os időszak első célkitűzéséhez, célja a legelmaradottabb országok és régiók felzárkóztatásának elősegítése, és 17 tagországban összesen 84 régiót érint (továbbra is azok a régiók tartoznak ide, ahol az egy före jutó vásárlóerő-paritáson mért GDP nem éri el az uniós átlag 75 százalékát). A második célkitüzés a regionális versenyképesség és foglalkoztatás növelése azokban az országokban, melyek nem tartoznak a konvergencia célkitüzés alá. A harmadik az európai területi együttmüködés célkitüzés, amely a közös helyi és regionális kezdeményezések által tovább erősíti a határokon átívelő együttmüködést.

\subsection{A Magyarországra érkezö transzferek várható szerkezete}

A 2007-2013-as tervezési időszakban a kohéziós politika keretében Magyarország 25,3 milliárd euró uniós forrásra jogosult, míg hozzájárulása 4,4 milliárd eurót tesz ki. Az összeg a Nemzeti Stratégiai Referenciakeret szerint használható fel, melyet az Európai Bizottság hagyott jóvá. A nemzeti stratégiai referenciakeretek célja, hogy a tagállamok gazdaságának modernizálására irányuló intézkedéseket tartalmazó általánosabb nemzeti programokat összekapcsolják a gazdasági növekedést és a munkahelyteremtést szolgáló lisszaboni stratégiával.

A magyar hatóságok a Nemzeti Stratégiai Referenciakeretben ismertetik, hogy mire fogják fordítani azt a 25,3 milliárd euró összegü európai uniós támogatást, melyet a következő hét év során az ország régióiban a növekedés és a munkahelyteremtés elősegítésére kapnak. A magyar nemzeti stratégiai referenciakeret pontjairól (köztük a prioritásokról, az indikatív éves elkülönítésekről és az operatív programokról) szóló európai bizottsági határozat kiadásával az elfogadási eljárás a végéhez ért. ${ }^{8}$

Magyarország a 2007-2013-as programozási időszakban az EU kohéziós politikájának keretében kapott 25,3 milliárd eurós támogatást a stratégiai dokumentumban meghatározott keret szerint használhatja fel. A lisszaboni menetrend célkitűzéseit szem előtt tartva a magyar

\footnotetext{
${ }^{7}$ Forrás: www.euvonal.hu.

${ }^{8}$ Az erről szóló jelentés az Európai Unió hivatalos internetes oldalán, a www.europa.eu címen érhető el.
} 
fejlesztési stratégia átfogó célkitűzései között a fenntartható fejlődés és a foglalkoztatottság növelése szerepel. A fenntartható növekedést olyan, a versenyképesség javítását célzó célkitüzések megvalósításával próbálják elérni, mint a tudásalapú gazdaság megerősítése, az üzleti környezet fejlesztése és gazdasági alapjának kiszélesítése. A cél az, hogy 2015-ig a vállalkozások által termelt hozzáadott érték 10 százalékkal növekedjen.

A foglalkoztatottság növelése az Európai Unió legfontosabb céljai közé tartozik. Ennek megvalósításához a munkaerőpiac mindkét oldalán meg kell tenni a szükséges lépéseket. Egyrészt a humántőke fejlesztése és a munkaerőpiaci aktivitás fokozása bővíti a munkaerőkínálatot, másrészt a munkahelyteremtés ösztönzése és a munkaerőpiaci környezet fejlesztése hozzájárul a munkaerő-kereslet növekedéséhez.

A Nemzeti Stratégiai Referenciakeret célja, hogy 2015-ig 4 százalékkal növekedjen a közszférán kívül dolgozók létszáma. A magyar nemzeti stratégiai referenciakeret hangsúlyozza, hogy a kohéziós politika milyen fontos szerepet tölt be a nyugdíjrendszer, a társadalom- és egészségbiztosítási rendszer, valamint az oktatás szerkezeti reformjainak támogatása terén. Emellett a következő programozási időszakban Magyarországnak egyértelmű prioritásként kell kezelnie az Európai Unió környezetvédelmi - különösen a szennyvízzel és az ivóvízzel kapcsolatos - jogszabályainak nemzeti jogba való átültetésével kapcsolatos határidők betartását. A közlekedési szektorban is fontos beruházásokat kell megvalósítani, melyek célja, hogy javuljon az ország nemzetközi megközelíthetősége, a vasúti és közúti beruházások által pedig javuljon a régiók megközelíthetősége.

A stratégia másik célja, hogy a magyarországi régiók közti egyenlőtlenségek problémájára megoldást találjon. A kiegyensúlyozott területfejlesztés a regionális növekedés központjainak fejlesztésével, a vidékfejlesztéssel, valamint a fejletlen kistérségek felzárkóztatásával valósítható meg. A Nemzeti Stratégiai Referenciakeret célkitűzései hat tematikus illetve területi prioritás, valamint 15 operatív program köré csoportosulnak. A prioritások között szerepel a gazdasági fejlődés, a társadalmi megújulás, a közlekedés fejlesztése, a környezet és az energia problémája, a területfejlesztés és az államreform.

A Nemzeti Stratégiai Referenciakeret felállítása során a tagállamoknak figyelembe kell venniük a 2007-2013-as időszakra vonatkozó közösségi iránymutatásokat, melyek különös hangsúlyt fektetnek az innovációra, a kutatásra és a technológiai fejlesztésre, az információs 
társadalomra, a környezetvédelemre, a megújuló energiaforrásokra és a munkahelyteremtésre. A Nemzeti Stratégiai Referenciakeret emellett szorosan kapcsolódik az egyes tagállamok nemzeti reformprogramjaihoz, melyek meghatározzák a munkahelyteremtésröl és növekedésről szóló lisszaboni stratégia célkitüzéseinek megvalósításához szükséges intézkedéseket.

Az EU-transzferek célkitüzésein túl fontos megemlíteni a támogatások felhasználási szerkezetének alakulását is. Az ezzel foglalkozó tanulmányok (például Bradley - Morgenroth [2004]) a beérkező transzfereket három fő csoportba sorolják: infrastrukturális beruházások, humántőke fejlesztése és a termelő szektornak nyújtott támogatások. A Magyarországra vonatkozó, múltbeli megoszlás a következő: az alapok 63 százalékát infrastrukturális beruházásokra, 17 százalékát humántőke-beruházásokra, 20 százalékát pedig termelő vállalatoknak nyújtott támogatásokra fordították a 2004-2006-os időszak során.

A támogatások elmúlt két programozási időszakra vonatkozó, előbb említett területek közti megoszlását az EU15 országok esetében az 1. számú táblázat szemlélteti: 
Strukturális Alapok elosztása az EU15 országokban az első célkitüzés keretein belül

\begin{tabular}{|c|c|c|}
\hline & 1994-1999 & $2000-2006$ \\
\hline Infrastruktúra & 29,8 & 41,3 \\
\hline Közlekedés & 15,7 & 19,8 \\
\hline Információ- és kommunikációtechnológia & 1,6 & 3,5 \\
\hline Energetika & 2,3 & 1,2 \\
\hline Környezetvédelem és vízügy & 7,5 & 12,8 \\
\hline Egészségügy és szociális ellátás & 1,7 & 3,9 \\
\hline Egyéb & 1,1 & 0 \\
\hline Emberi erőforrások & 24,5 & 23,1 \\
\hline Oktatás & 6,9 & $\mathrm{n} / \mathrm{a}$ \\
\hline Felnőttképzés & 17,4 & $\mathrm{n} / \mathrm{a}$ \\
\hline Egyéb & 0,2 & $\mathrm{n} / \mathrm{a}$ \\
\hline Versenyképes környezet & 41 & 33,8 \\
\hline Ipar és szolgáltatások & 19,9 & 11,4 \\
\hline Kutatás-fejlesztés, innováció & 3,5 & 6 \\
\hline Mezőgazdaság, vidékfejlesztés, halászat & 15,2 & 13,7 \\
\hline Turizmus & 2,4 & 2,7 \\
\hline Egyéb & 4,7 & 1,8 \\
\hline Összesen & 100 & 100 \\
\hline
\end{tabular}

Forrás: European Commission [2001]: Second report on economic and social cohesion, European Commission [2004]: Third report on economic and social cohesion

Látható, hogy a Strukturális Alapokat figyelembe véve a támogatási struktúra 2000-2006-ra eltolódott az infrastruktúra irányába, a humán erőforrás támogatottsági aránya pedig csökkent. Ennek az egyik oka, hogy egyre nagyobb hangsúlyt kapnak a telekommunikációs és információtechnológiai fejlesztések valamint a környezetvédelmi beruházások. A másik ok, hogy a Strukturális Alapok sokkal hatékonyabban kerülnek felhasználásra a nagyobb projektek esetében - ilyenek például az infrastrukturális beruházások -, ezzel szemben a kisebb és összetettebb projektek esetén - mint például a humántőkébe történő befektetések -, általában gyengébb a megtérülés ${ }^{9}$.

\footnotetext{
${ }^{9}$ Lásd: European Commission [2004]
} 
Ez alapján Magyarországra vonatkozóan is levonható az a következtetés, hogy a következő időszak folyamán egyre fontosabbá válik a környezetvédelem támogatása, és a technológiai fejlesztéseknek is egyre növekvő szerepe lesz, így a 2007-2013-as időszakot követően a támogatás szerkezetében további, az infrastruktúra irányába történő eltolódás várható.

Az éppen futó, 2007-2013-as programozási időszakra vonatkozóan sajnos még előzetesen sem érhetők el hivatalos adatok. Mindez nem meglepő annak fényében, hogy az egyes tagállamoknak van bizonyos mozgásterük az aktuális arányok kialakításában, és a válság éveiben törekszenek is a változtatásokra. Ennek fényében arra lehet számítani, hogy elötérbe kerülnek a gazdaságélénkítő és munkahelyteremtő programok a csak hosszabb távú előnyökkel kecsegtető infrastrukturális beruházásokkal szemben.

A 2013 utáni időszakra vonatkozóan még nem véglegesek az EU pénzügyi alapjaival kapcsolatos elképzelések. Ebböl adódóan jelenleg nem tudhatjuk pontosan, hogy milyen nagyságú és szerkezetü támogatási kerettel számolhatunk a következő évtized második felében. Bizonyos folyamatok azonban valószínüsíthetőek, és ennek megfelelően alakítottuk ki várakozásainkat, illetve ebből adódóan a hatásvizsgálatokhoz tartozó külső feltételrendszert. Eszerint egyrészt arra számítunk, hogy a 2014-2020-as programidőszakban sem szünnek meg a támogatások, Magyarország várhatóan továbbra is nettó haszonélvezője lesz a közös európai költségvetésnek. A transzferek értéke azonban várhatóan csökkenni fog. Másrészt arra is számítani kell, hogy a már megindult szerkezeti változások folytatódnak, nagy valószínüséggel tovább csökken a mezőgazdasági szubvenciókra költött összegek aránya, növekszik viszont az infrastrukturális támogatások aránya, azon belül elsősorban a környezetvédelem és az információtechnológia lehetnek a leginkább kedvezményezett területek.

\subsection{Az EU-transzferek közvetlen hatásai a növekedésre}

A dolgozatomban elsősorban az Európai Uniótól kapott támogatások közvetett, azaz a TFP-n keresztül megvalósuló hatásaira koncentrálok, azonban az EU-transzferek számos csatornán keresztül közvetlenül is befolyásolhatják egy ország hosszú távú gazdasági növekedését. 
A pénzügyi támogatások keresletnövelö hatása önmagában is ösztönzi a gazdaságot, a pénzek döntő hányadát ugyanis helyben költik el, ami javítja a vállalkozások értékesítési lehetőségeit. A fizikai infrastruktúra javítása ösztönzi a kereskedelmet, vonzza a beruházásokat, így hozzájárul a gazdasági hatékonyság fokozásához. Elsősorban az újonnan csatlakozott tagországoknál figyelhető meg, hogy elégtelen vagy nem megfelelő minőségü vasúti és közúti kapacitás komoly gátjává válhat a fejlődésnek. Az EU-tól kapott tőketranszferek bővítik a beruházásokat, növelik a vállalkozások versenyképességét, ezáltal a GDP-növekedésre is jótékony hatással vannak.

A humántőke fejlesztését szolgáló programok növelik a foglalkoztatást, ami önmagában nagyobb hozzáadott-értéket eredményez. Ezzel együtt növekszik a vásárlóerő is, ami tovább élénkíti a gazdaságot. Ez utóbbi hatás jelentkezik a jövedelempótló támogatások esetében is, bár azok közvetlenül nem jelentenek produktív beruházásokat. A kutatásra és fejlesztésre, valamint az információtechnológiára adott támogatások hosszabb távon eredményezik a versenyképesség javulását, ezen a téren az egész uniónak komoly lemaradása van a világ többi gazdasági centrumához képest.

A környezetvédelemre fordított kiadások előnyei is csak hosszú távon jelentkeznek, ráadásul közvetlen, számszerüsíthető nyereség helyett ebben az esetben a későbbi magasabb költségek elkerülése jelenti a(z implicit) hasznot. Ez azonban nem lebecsülendö, több évtizedes távlatban a halmozódó környezeti károk - ökológiai szakértők egybehangzó állítása szerint jelentősen visszavethetik az akkori gazdasági fejlődést.

Fontos megemlíteni azt is, hogy az uniós transzferek felhasználásának hatékonysága illetve eredményessége, és ebből adódóan azok hatása a hosszú távú növekedésre nagymértékben függ a fogadó ország intézményrendszerétől. A témáról kiváló áttekintést ad Perger [2009]. Tanulmányában nem csak a környező országok intézményi megoldásait mutatja be, hanem a tanulságok levonásával egyidejüleg javaslatot tesz a hazai intézményrendszer átalakítására is. 


\section{Az EU-transzferek makrogazdasági hatásvizsgálatának nemzetközi és hazai tapasztalatai}

Az Európai Unió kohéziós politikája hatékonyságának vizsgálatára alapvetően három típusú értékelési módszer létezik: esettanulmányok, ökonometriai becslések, valamint modellszimulációk [Ederveen, 2002a]. Az EU által nyújtott tőketranszferek konvergenciára gyakorolt hatásáról a különböző tanulmányok nem adnak egységes képet. A kirajzolódó kép már csak azért sem lehet teljesen egyértelmü, mert az említett értékelési módszerek különböző előnyökkel és hátrányokkal bírnak, sőt az általuk megválaszolható konkrét kérdések sem mindig azonosak. Az esettanulmányok például általában pontos képet adnak egy adott projekt jellemzőiről vagy a megvalósítás menetéről, azonban sokkal kevésbé alkalmasak az alapok hatásainak számszerüsítésére, illetve régiós vagy országszintü következtetések levonására. Ezért mindhárom módszer legfontosabb eredményeit áttekintem. A modellszimulációkat a többi módszernél nagyobb terjedelemben tárgyalom, ugyanis a dolgozat későbbi részeinek szempontjából azok jóval relevánsabbak.

\subsection{A korábbi csatlakozók modellrendszere: HERMIN}

A HERMIN modellcsalád kifejlesztésének legfőbb célja az volt, hogy modellezhetővé váljon az Európai Unióban közösségi támogatást kapó periférikus régiók gazdasági fejlődése, és segítségével elemezni lehessen a támogatásoknak a gazdaság kínálati oldalára való hatását. Ennek megfelelően a modellek kiemelten foglalkoznak a külkapcsolatokkal, valamint a jövedelemáramlásokkal. A modellrendszer további célja az Európai Unióhoz később csatlakozott országok gazdaságának modellezése a csatlakozás előtt és azt követően.

Az első HERMIN modellt Bradley, Wealan és Wright [1995] dolgozta ki az ír gazdaság elemzésére. Ennek alapján készítette el Herce és Sosvilla-Rivero [1995] a modell spanyol változatát, majd Modesto és Neves [1995] alakította ki a portugál gazdaságra alkalmazott HERMIN modellt. A későbbiekben egyre szélesebb körben adaptálták az említett szerzők eredményeit, mára közel egy tucat HERMIN modell készült el, többek között Görögországra, Csehországra, Szlovéniára és Romániára. A legfrissebb a magyar HERMIN modell, amely jelenleg tesztelés alatt áll. Bradley számos tanulmányban alkalmazta a nevéhez köthető 
módszereket, az egyik legfontosabb kutatási területe az uniós transzferek makrogazdasági hatásainak vizsgálata. ${ }^{10}$

Amikor a korábban EU-perifériának számító országok (Írország, Spanyolország, Portugália és Görögország) az unióhoz csatlakoztak, sok szempontból hasonló helyzetben voltak, mint a később csatlakozott közép-európai államok. Ennek köszönhetően a modell támpontot adott a magyar gazdaságra vonatkozó modell kialakításában, továbbá segítséget nyújtott az adathiány miatt nem becsülhető paraméterek meghatározásához.

A HERMIN modellekben a kínálati oldalon az egyéb modellekben megszokott Cobb-Douglas típusú termelési függvény helyett egy Leontieff-típusú függvény szerepel, ahol a hangsúly nem a hazai tényezőárakon van, hanem a technológia alakulásán és a világpiaci relatív faktorárakon. ${ }^{11}$

A termelö szektor tradable és non-tradable szektorra válik szét, mivel a külgazdasági változások közvetlenül a tradable szektorban csapódnak le, és hatásuk ezután, közvetve jelentkezik a non-tradable szektorban, ezenkívül a tradable szektor termelése a világkereslet függvénye, míg a non-tradable szektor termelése a hazai kereslet által meghatározott. Az állami szektor is különválik a többitől, mivel itt a gazdasági döntések főleg politikai célok alapján történnek.

A tradable szektor modellezésénél érdemes figyelembe venni az ír gazdaságra felállított modelleket, mivel - hasonlóan hazánkhoz - Írországban is a szektor termelésének jelentős részét a megtelepedett, nagyrészt exportra, intermediare termékeket előállító multik adják.

A modellépítés célja, a korábban létező makromodellek (pl. HERMES) és a legújabb ökonometriai eredmények felhasználásával, egy növekedésorientált modell létrehozása volt. A modell azért erősen növekedésorientált, mert célja az EU csatlakozással a gazdaságot érő hosszú távú kínálati sokkok (pl. strukturális reformok, infrastruktúrafejlesztési támogatások stb.) elemzése. A modellbe némi dinamikát visz, hogy a termelési függvényben a termelési tényezők iránti szükséglet a tényezők késleltetett értékeitől is függ. A versenyképesség

\footnotetext{
${ }^{10}$ Lásd: Bradley-Morgenroth-Untiedt [2003] és Bradley-Morgenroth [2004]

${ }^{11}$ Lásd: Bradley-Modesto-Rivero [1995]
} 
alakulása miatt kiemelkedően fontos a munkabérek alakulása, mivel a versenyképességet meghatározó tényezők közül ezek a leginkább volatilisek.

A kínálati oldalon a termelési függvény szerint a hozzáadott érték két tényező, a munka és a tőke függvénye. A technikai fejlődést egzogén trendként vették figyelembe, és hosszú távon feltételezik az állandó volumenhozadékot.

A keresleti oldalon, mivel az empirikus kutatások szerint a felzárkózó országaiban a háztartások többsége likviditáskorláttal küszködik ${ }^{12}$, a fogyasztási függvény legföbb magyarázó változója a rendelkezésre álló jövedelem. A beruházások alakulása a relatív tényezőárak és (a megtakarítási határhajlandóságon keresztül) a kibocsátás függvénye.

A modellben a várakozások autoregresszívek, azaz a szereplök az eddigi trendeket vetítik ki a jövőbe. Ez a modell egyik gyenge oldala, mert emiatt a döntéshozók reakciói a gazdaságpolitikai, vagy egyéb változásokra elkésettek a valós helyzethez képest, amit a racionális várakozások elméletének felhasználásával lehetne orvosolni.

A HERMIN modell a legfőbb strukturális jellemzőkre koncentrál a kohéziós típusú gazdaságoknál az alábbi tényezőket figyelembe véve:

- a gazdasági nyitottság foka, a világkereskedelemnek való kitettség, és a külső és belső sokkokra való reakció,

- a kereskedelmi és nem-kereskedelmi szektor relatív mérete és jellemzői, fejlődésük, termelési technológiájuk és strukturális változásaik,

- az árak és bérek meghatározódásának mechanizmusa,

- a munkapiac müködése és rugalmassága a nemzetközi és régiók közti migráció lehetséges szerepével,

- az állami szektor szerepe és az államadósság felhalmozódásának lehetséges következményei, valamint az állami és magánszektor közti kölcsönhatás a gazdaságpolitikában.

\footnotetext{
${ }^{12}$ Ennek okai között többek között a pénzügyi rendszer fejletlenségét és az infláció miatti magas kamatokat szokták megemlíteni
} 
Ennek megfelelően a HERMIN alapmodellje négy szektorból áll, ezek a termelés, a piaci szolgáltatások, a mezőgazdaság és a kormányzati szolgáltatások. A dezaggregálásnak ez a szintje minimálisan szükséges a föbb szektorális változások azonosítására a felzárkózó gazdaságok esetében a Strukturális Programok időszaka alatt. A modell három fő részből, a kínálati, a keresleti és a jövedelem-újraelosztási blokkból áll.

A konvencionális keynesi mechanizmusok rövid távon minden HERMIN modellnek szerves részét képezik. A kiadási és jövedelemelosztás alkomponensek generálják a standard bevételkiadási mechanizmusokat. Azonban a modellnek vannak neoklasszikus jellemzői is, főleg a kínálati oldallal kapcsolatban. Ezért a termelésben az output nem egyszerüen keresletvezérelt, hanem befolyásolhatja az ár és a költség, mint versenyképességi tényező, ahol a vállalatok a minimális költségü területeket keresik a termeléshez [Bradley és Fitz Gerald, 1998]. Ehhez adódnak hozzá a tényezőkeresletek a termelésben és piaci szolgáltatások, amelyek a CES termelési függvény korlátainak használatából származnak, melyben a tőke/munka arány érzékeny a relatív tényezőárakra. A strukturális Philips-görbe mechanizmus beépítése a bértárgyalásokba további relatív ár-hatásokat vezet be.

A modell három módszert alkalmaz a GDP mérésére: az output alapú, a kiadás alapú és a bevétel alapú módszert. Kibocsátási alapon a HERMIN a GDP-t négy fő szektorba dezaggregálja, ezek a termelési, a piaci szolgáltatások, a mezőgazdasági és a kormányzati szektor. A kiadási oldalon a HERMIN a GDP-t öt elemre dezaggregálja: magánfogyasztás, közfogyasztás, beruházások, állományváltozások és a nettó kereskedelmi mérleg. Végül a nemzeti bevétel az output oldalon határozódik meg, privát és közszektorra osztható.

A kibocsátás minden elemét modellezik, ezért a kibocsátás-kiadás azonosság által reziduális elven meghatározható a nettó kereskedelmi hiány/többlet. Végül a modellben lévő egyenletek viselkedési és azonossági egyenletekre oszthatók. Előbbi esetében, a közgazdasági elméletet és az adatokhoz történő kalibrálást arra használják, hogy definiálják az összefüggéseket. Az azonosságok esetében a nemzeti számlák logikáját követik, de fontos következménye van a modell viselkedésére vonatkozóan is.

A szokásos makroökonómiai kapcsolatok modellezésén túl, a regionális modellezésnek egy fontos szempontja az, hogy számba kell venni a spillover hatásokat, az összekapcsolódásokat és az elszivárgásokat, amelyek nemzeti szinten kevésbé fontosak, de jelentős hatásuk lehet 
regionális szinten. Ez különösen fontos a strukturális alapok elemzéséhez, mivel ilyen beruházások valószínủleg nagymértékü, régiók közti kereslet és kínálati spillover-eket hoz létre. Például, egy beruházásnak hatása lehet a munkaerőpiacra azáltal, hogy többletfoglalkoztatást generál. Természetesen az egyének ingázhatnak régiós határokon keresztül, vagy még akár el is költözhetnek munkahely-találás érdekében. Így a beruházás hatással lehet a munkaerőre azáltal, hogy migrációt és ingázást idéz elő. Ezek a munkaerőpiaci hatások már beépültek számos már létező makrogazdasági modellbe, például a keletnémet modellbe. ${ }^{13}$

A HERMIN modellek jellemzően mintegy 250 egyenletet tartalmaznak, amelyek nagy része a modell átláthatóságának növelését, illetve a szimulációk és a gazdaságpolitikai elemzések segítését szolgálják. A modell lényegi részét a kb. 20 viselkedési egyenlet adja, melyeket kalibrálást követően kerülnek a modellbe. Ilyen például a GDP keletkezése, vagy a tényezőkereslet rendszere a termelésben és a szolgáltatások piacán. A többi egyenlet becslésénél a rendelkezésre álló adatok rövidsége miatt csak a legkisebb négyzetek módszere (OLS), illetve a maximum likelihood (ML) módszer került alkalmazásra, de ha a későbbiekben sikerül megfelelő segédváltozókat találni, akkor tervezik az instrumentális változók módszerének alkalmazását. A modell Winsolve nevű programcsomag segítségével szimulálható. A sokkok elemzése illetve az outputok más eredményekkel történő összevetése után a struktúra újra becsülhető, amennyiben szabálytalan viselkedési minták alakulnának ki.

2003-ban az eredeti négyszektoros HERMIN új változata is elkészült, amely már magában foglalja a modell-konzisztens várakozásokat, és arra is alkalmassá vált, hogy tesztelni lehessen vele az „expansionary fiscal contraction”"14 hipotézisét. A HERMIN modellezési projekt a közelmúltban inkább extenzíven, mint intenzíven fejlődött. A hangsúly ugyanis azon volt, hogy ugyanazt az alapmodell-struktúrát az országok egyre növekvő csoportjára terjesszék ki. Csak Észtország és Lengyelország esetében jutott el a munka abba a fázisba, hogy megengedte a modellezés „mélyítését”, azaz elmozdulást a szektorális dezaggregáció irányába. Később dől el, hogy a közép-kelet-európai országok modellezői túllépnek-e az

\footnotetext{
${ }^{13}$ Lásd: Bradley et al. [2003]

${ }^{14}$ Ennek lényege, hogy a hipotézis szerint a fiskális megszorítás bizonyos esetekben növelheti a GDP-t. Részletesebben lásd: Kotosz [2006] vagy Barry-Devereux [2003]
} 
alapvető HERMIN modellen, hogy így a régiót közvetlenebbül érintő speciális kérdéseke is válaszokat lehessen adni.

HERMIN modellek azonban nem csak azért készülnek, hogy tanulmányozni lehessen bizonyos gazdasági struktúrákat. Legfőbb hasznuk abban rejlik, hogy képesek vizsgálni olyan mechanizmusokat, melyeken keresztül az EU Strukturális Alapjai kifejtik esetleges kedvező hatásukat.

A HERMIN modellel végzett ex-post szimulációk alapján számszerüsíthető a már megvalósult programok potenciális hatása ${ }^{15}$ is. Az 1994-1999-es tervezési időszakban felhasznált transzferek hatását Görögországra, Spanyolországra, Portugáliára, Írországra, Kelet-Németországra és Észak-Írországra vonatkozóan számszerüsítették. A szimulációk eredményeit egy olyan alappályához viszonyították, melyben azt feltételezték, hogy semmilyen támogatás nem érkezett az Európai Unióból. A modell alapján az említett időszakban a strukturális támogatások hatása Portugáliában és a kelet-német régióban volt a legjelentősebb, a GDP szintje az 1999-re 4-5 százalékkal haladta meg az alappálya esetén kialakuló szintet. Görögország és Írország esetében mérsékeltebb hatás mutatkozott, 2-3 százalék körüli GDP-többletet eredményeztek az adott időszakban beérkező támogatások. A spanyol és északír régiók esetében pedig csekély, mindössze 1,2-1,4 százalékos a kibocsátásitöbblet a szimulációk eredményei szerint. A beáramló transzferek következtében a foglalkoztatottság szintje is emelkedett az alapváltozathoz képest, a munkanélküliségi ráta pedig valamelyest csökkent.

A 2004-ben rendelkezésre álló információk alapján a HERMIN modellek segítségével elkészítették az egyes országokra vonatkozó előrejelzéseket 2007-13-as pénzügyi tervezési időszakra is ${ }^{16}$. A szimuláció eredményei alapján Magyarországon 2013-ra az alapok által finanszírozott projektek addicionális hatására a GDP szintje 8,4 százalékkal emelkedhet. A fizikai infrastruktúra több mint 35 százalékkal nő, a humántőke viszont csak 7,5 százalékkal. A foglalkoztatottság szintje 4,5 százalékponttal lehet magasabb a periódus végére, ami 157 ezer fős bővülést jelentene. Ezen belül a szolgáltató szektor foglalkoztatottsági szintje erősebben emelkedik mint az ipari ágazatoké. A strukturális alapok hatásának köszönhetően a

\footnotetext{
${ }^{15} \mathrm{Az}$ ismertetett eredmények Economic and Social Research Institue [2002] tanulmányban jelent meg, az Európai Bizottság honlapján elérhetö: ec.europa.eu

${ }^{16}$ Lásd Bradley és Morgenroth [2004] ex-ante szimulációit.
} 
termelékenység szintje a két szektorban azonosan átlagosan 4 százalékkal lesz magasabb a tervezési periódus végére. Míg a fogyasztás szintje 5,9 százalékkal, a beruházásé több mint 41 százalékkal emelkedik 2013-ra. A hosszabb távú hatások alapján a GDP szintje 2020-ra 4 százalékkal lenne magasabb, mint az alapszcenárióban, a foglalkoztatottság azonban a 2013 utáni időszakban már nem haladja meg az alapváltozatban jelzett szintet. A mai olvasó számára rendkívül optimistának tünő eredmények védelmében szól, hogy 7-8 évvel ezelőtt a kutatók még nem sejthették, hogy 2008-ban egy évekig elhúzódó pénzügyi válság alakul majd ki, aminek hatásai épp az Európai Unió tagállamait, és azon belül a térségünket sújtják majd a legerősebben. És bár a saját számításaim a fenti eredményeknél jóval kisebb hatásokat valószínüsítenek, figyelemre méltó, hogy azok iránya és egymáshoz viszonyított nagyságrendje nem változott.

\subsection{A QUEST modell}

A QUEST modell kialakításakor megfogalmazott legfőbb cél az volt, hogy általa elemezhetővé a maastricht-i kritériumoknak történő megfelelés hatásai a növekedésre és a foglalkoztatottságra, valamint a fiskális konszolidációk és strukturális reformok hosszú távú hatásai Európában. A konkrét hatásvizsgálatok kiterjedtek a monetáris politika fiskális következményeire, a különböző adóreformok és ÁFA harmonizációk makroökonómiai hatásaira, a Transzeurópai Közlekedési Hálózat foglalkoztatottsági és növekedési eredményeire, Spanyolország, Portugália, Görögország és Írország esetében pedig a Strukturális Alapok hatásaira.

A QUEST egy erős mikroökonómiai megalapozottságú globális makroökonómiai modell, amely egy jól specifikált kínálati oldalt tartalmaz, lehetővé téve az infrastruktúrába és humántőkébe történő beruházások produktív hatásainak modellezését. A háztartások és a vállalatok viselkedési egyenletei a hasznosság illetve a profit intertemporális optimalizálásának eredményeként adódnak. A modell képes a magánszektor fiskális támogatásokra adott reakcióinak megjelenítésére, melyek között gyakran megjelenik a kiszorítási hatás is. ${ }^{17}$

17 Azaz a modell számol azzal a lehetőséggel, hogy a közösségi kiadások kiszoríthatnak bizonyos magánberuházásokat. 
A modell a neoklasszikus-keynesi szintézisen alapul, ami a dinamikus általános egyensúlyi modellek merevségeit kapcsolja össze a keynes-i ragadóssággal. A modell dinamikus válaszreakciói hangsúlyozottan figyelembe veszik a kiigazítási költségek létezését. A gazdaság kínálati oldalát neoklasszikus kínálati függvénnyel írják le, ami azt eredményezi, hogy az egyensúlyi növekedési pálya az egzogén technikai haladás és a népesség növekedési üteme által meghatározott.

A modell szerint hosszú távon a vállalatok nem tökéletesen versenyzők, hanem monopolisztikus versenyben vesznek részt, ezért hosszú távon is lehet árrésük a határköltségen felül. Ennek következtében a gazdasági aktivitás szintje alacsonyabb lesz a tökéletes versenyt feltételező modellhez képest. A modell rövid távú viselkedését a hagyományos keynes-i jellemzők befolyásolják, vagyis a bérek és az árak nem tökéletesen rugalmasak, a fogyasztás esetében létezik likviditási korlát, továbbá a beruházási aktivitás és munkaerő-állomány változtatása kiigazítási költségekkel jár.

A reálkamatláb és a reálárfolyam endogén módon határozódik meg a modellben, a monetáris politikát pedig a Taylor-szabály ${ }^{18}$ határozza meg. A kohéziós politika kezdeti kedvező eredményei mérséklődhetnek a tőkeállomány növekedésével párhuzamosan, aminek oka a már említett kiszorító hatás érvényesülése. A hosszú távú növekedési többlet meghaladja a rövid távú keresleti hatásból adódó növekményt, és a transzferek felhasználásából adódó növekedési többlet a támogatási perióduson túl is érzékelhető marad.

A QUEST egy részben becsült modell, ugyanis a közvetlenül nem becsülhető egyenleteket az empirikus irodalomban rendelkezésre álló eredmények felhasználásával készítették. Az egyes országokra alkalmazott paraméterrendszerek között jelentős különbségek lehetnek, föleg a kereskedelmi kapcsolatok iránya és intenzitása, az importrészesedések, valamint a nemzeti számlákban megjelenő jövedelmi részesedések területén.

A strukturális paraméterek egységesek valamennyi országban, de az intézményi különbségeknek fontos szerepe van. A régi és új tagállamok közti legföbb különbség a nyitottság fokában van, az új tagországokban ugyanis általában magasabb az export és az

\footnotetext{
${ }^{18}$ Kamatszabály, melyben az optimális kamat az inflációs célkitűzéstől való eltérés és a reálkibocsátás trendtől való eltérésének függvényeként alakul.
} 
import aránya a GDP-hez viszonyítva, így sokkal inkább kitettek a külső konjunktúra ingadozásainak. További különbség, hogy ezekben az országokban az unión belüli külkereskedelem aránya igen lényegesen meghaladja a régi tagállamok átlagát.

A kohéziós programokhoz kapcsolódó támogatások kormányok közti transzferként jelennek meg a modellben. További feltevés, hogy ezek a transzferek a régi tagállamokat terhelik erőteljesebben, és az elmaradottabb régiók több támogatást kapnak, mint amennyit befizetnek. A kohéziós politika esetében teljesülnie kell az addicionalitás és a társfinanszírozás elvének. Az addicionalitási kritérium megköveteli, hogy a Strukturális Alapok a hazai finanszírozású kiadásokat egészítsék ki, és ne helyettesítsék azokat. A társfinanszírozás szabálya pedig azt jelenti, hogy saját forrásokkal is ki kell egészíteni az EU által nyújtott támogatásokat.

Veld [2007] ismerteti a 2007-2013-as programozási időszak kohéziós politikai programjaira vonatkozó szimulációs eredményeket. A QUEST modellel végzett számítások az új tagállamok esetében azt mutatják, hogy a pótlólagos kiadásoknak azonnali keresleti oldali hatása van a fogadó országok esetében, és ez a hatás halmozódik az ezt követő időszakban. A további kiadások megnövelik a fogyasztás szintjét, és a magasabb permanens jövedelem növekvő kiadásokhoz vezet. Bár a kormány közvetlen támogatásokkal ösztönzi a vállalati szektor beruházásait, a szimuláció első éveiben mégis érvényesül a magánberuházásokat kiszorító hatás, és csak a későbbi években éri el a vállalati beruházások összege az alappályában szereplő értéket. A további kiadások magasabb inflációhoz vezetnek, a kamatlábra növekvő nyomást gyakorolnak, és mindez a szimuláció első éveiben jelentős reálfelértékelődéshez vezet.

A kibocsátástöbblet fokozatosan növekszik, ahogy a kínálati oldali hatások erősödnek, és az output átlagosan több mint 5 százalékkal bővül az alappályához képest az új tagországok esetében. Ennek a növekménynek a nagy része permanens, a kohéziós politikai programok lezárulása után több mint 4 százalékkal magasabb szinten marad a GDP az alapváltozathoz képest. Az első években a keresletbővülésnek köszönhetően növekszik a foglalkoztatás, azonban ez a hatás ezt követően érezhetően csökken, ahogy a termelékenységjavulás következtében emelkedni kezdenek a reálbérek. 
A QUEST modellel a 2000-2006-os pénzügyi tervezési időszakra vonatkozóan is végeztek ex-ante szimulációt ${ }^{19}$, az akkori négy kohéziós országra vonatkozóan. Az eredmények azt mutatták, hogy a transzferek hatása sokkal kisebb a más modellek által becsült értékeknél. Ez elsősorban a szereplők várakozásaival, előretekintő viselkedésével, a hosszú távú reálfelértékelődéssel és a magánberuházásokat érő kiszorítási hatással magyarázható.

Érdekesség, hogy Varga - in 't Veld [2011] másfél évtizeddel később a modell legújabb változatával, a QUEST III segítségével végzett ugyanerre az időszakra - immár utólagos számításokat a Kohéziós Alapok hatásaira vonatkozóan. Fontos hangsúlyozni a feltételrendszerek közötti különbségeket. A későbbi szerzők már tudták, hogy időközben megvalósult az EU keleti bővítése, így sokkal több tagállam részesedett az uniós forrásokból. Az elosztási elvek is átalakultak, a korábban feltételezettnél gyorsabban csökkent a mezőgazdasági támogatások súlya, és több jutott a kohéziós és strukturális politikákra. Ezek után nem meglepő, hogy a számítások eredménye is eltérő, az új adatok szerint ugyanis a kohéziós transzferek a korábban becsültnél jelentősebb növekedési nyereséget eredményeztek. A szerzők ugyanakkor kiemelik, hogy ebben meghatározó szerepe volt annak, hogy az egységes európai piac létrejöttével számos területen vált lehetségessé méretgazdaságosság kihasználásával javítani a gazdaság hatékonyságát és versenyképességét.

\subsection{Az E3 modellek}

A makromodellezés fontos irányzatát képviselik az E3-típusú modellek, azaz amelyek együtt modellezik a makrogazdaságot, a környezetet, és ennek megfelelöen viszonylag részletes módon ábrázolják a környezetkárosításban kiemelt szerepü energiaszektort (EconomicsEnvironment-Energy). Az E3 modellezés alapeszméje az, hogy nem lehet hosszú távú hatásokat reálisan elemezni, illetve elörejelezni a környezeti hatások figyelembe vétele nélkül. Ezeknek a hatásoknak a reális elörejelzése azonban azt is igényli, hogy a termelést és felhasználást viszonylag dezaggregáltan kezeljék, ami föleg hosszú távú modellek esetében jelentős technikai problémákat vet fel a megoldhatóság szempontjából. A másik fő nehézség abban áll, hogy a környezeti hatásokat nemzetközi szinten is kell követni, ami olyan modellek megalkotását kívánja, amely külön blokkokként kezeli az egyes nemzetgazdaságokat, és azok

\footnotetext{
${ }^{19}$ Roeger [1996]: Macroeconomic evaluation of the effects of CSF with QUEST II
} 
kölcsönhatásait is leírja. Az ilyen modelleket éppen ezért többnyire nemzetközi együttmüködések révén fejlesztik és alkalmazzák. A környezeti hatások közül a modellek kiemelten az üvegházhatású gázok kibocsátását követik, amelyekre az európai országok konkrét vállalásokat tettek, és amelynek alakulására az energiatermelésnek és felhasználásnak kiemelt szerepük van. Az EU-ban ismert modellek közül kettőt emelünk ki: az egyik az elsősorban görög koordinációval (National Technical University of Athens) kifejlesztett GEM-E3 modell (General Equilibrium Model for Energy-Economy-Environment interactions), a másik a Cambridge Econometrics által kifejlesztett és gondozott E3ME modell (Energy-Environment-Economy Model for Europe). Valójában modellcsaládokról beszélhetünk, mivel a konkrét alkalmazások sokrétüek, és ezeknek megfelelően szükség szerint alakítják a modelleket.

$G E M-E 3^{20}$

A GEM-E3 modell fejlesztésében és alkalmazásában magyar kutatók, így a Budapesti Corvinus Egyetem munkatársai is részt vesznek, elsősorban a sevillai székhelyü európai kutatóintézet, a Joint Research Center - Institute for Prospective Technological Studies kutatási tevékenységének részeként.

A GEM-E3 egy számszerüsített, több nemzetgazdaság müködését és kölcsönhatásait leíró általános egyensúlyi modell, amely a tulajdonosi szektorok (gazdasági szereplők) termelési és fogyasztási viselkedését követi. A szereplők összhasznaikat, illetve hasznossági függvényeiket maximalizálják a költségvetési korlátaik figyelembe vételével. A modell walras-i értelemben vett piactisztító egyensúlyi árakat határoz meg a termékekre, szolgáltatásokra, tőkejavakra és a munkaerőre. A modell endogén módon veszi figyelembe az ágazatok közötti kapcsolatokat, az egyes országok közötti kereskedelmet, a technikai haladást, a tőkefelhalmozást, követi a főbb stock és flow mutatók alakulását, valamint a várakozások hatásait. Mint endogén növekedési modell, a technikai haladást a kínálat meghatározásában szerepet játszó Total Factor Productivity révén ábrázolja. Erre a kutatás-fejlesztéshez köthető tőkeállomány szintje hat, de szupranacionális jellege miatt a kölcsönhatásokat is, azaz a technológia megújulásához hozzájáruló kereskedelemi tevékenységet is figyelembe veszi. A modell alkalmas arra, hogy az állami beavatkozások, illetve fiskális politika hatásait

\footnotetext{
${ }^{20}$ Lásd: National Technical University of Athens: The GEM-E3 model reference manual
} 
elemezze, továbbá rendelkezik egy opcionálisan alkalmazható monetáris részmodullal is. Outputként adódik az energiamérleg, meghatározhatók a kibocsátások, illetve a szükséges kibocsátás-csökkentések, az egyes országok ÁKM-tábláinak előrevetítései, a főbb makrogazdasági növekedési és egyensúlyi mutatók alakulása stb. Minden országra szimultán határozódnak meg az egyensúlyi árak, és ennek megfelelően adódnak az egyes országok külkapcsolatai.

A fenti tulajdonságoknak köszönhetően a modellt az EU számos igazgatósága fel tudja használni a döntés-elökészítésben (az ipar-, adózási és környezeti politikai koncepciók kialakításában, valamint a kutatás és fejlesztés támogatásában). A GEM-E3-nak fontos szerepe van az uniós szintü és az országokon belüli forráselosztás és közfinanszírozás megtervezésében. A modell különféle alternatív formában is alkalmazható, ezeket a különböző lezárási lehetőségek biztosítják. Így például alkalmassá tehető egyetlen nemzetgazdaság elkülönült modellezésére is, a tőkemobilitás figyelembe vételére vagy kizárására, integrált vagy szegmentált piacok ábrázolására, rögzített vagy szabadon alakuló fizetési mérleg, munkaerő-kínálat és államháztartási hiány alkalmazására, kibocsátási korlátok figyelembe vételére, az IS-LM mechanizmus modellezésére, tökéletes verseny, vagy monopóliumok ábrázolására.

$E 3 M E^{21}$

Az E3ME modellt elsősorban különféle szcenáriók elemzésére alkalmazzák. A modell alkalmas a környezeti adók és szabályozás hatásainak modellezésére. Különféle input sokkok esetén vizsgálhatók a modell változóira való hatások. Így például modellezhetők a szabályozásbeli változások, vagy valamely mutató (pl. energiaárak) hirtelen megváltozásának hatásai, az ezekre való érzékenység számszerüsítése akár ex post, akár ex ante módon. Mint ilyen, az E3ME is döntéselőkészítésre alkalmas modell.

A modell az ESA95 kategóriáinak megfelelő változókat használ, és részletesen ábrázolja a munkapiaci folyamatokat. Az egyes országokra, azon belül pedig az egyes ágazatokra vonatkozó modellegyenletek ökonometriai becsléseken alapulnak. A modell adatbázisa kb. 40

\footnotetext{
${ }^{21}$ Lásd: Pollitt, H. - Chewpreecha, U. - Summerton, Ph. [2007]
} 
éves idősorokat tartalmaz (elsősorban az OECD, az International Energy Agency és az Eurostat adatait használják), ami természetesen korlátozza az alkalmazhatóságát, hiszen nem minden országra állnak rendelkezésre ilyen hosszú, homogénnek tekinthető idősorok. A modell dezaggregált, 42 ágazatot különböztet meg, a 13 réteget elkülönítő lakossági fogyasztást pedig 43 kategóriára bontja. Részletesen ábrázolja az energetikai célú felhasználásokat és az ezekhez tartozó különféle környezetkárosító kibocsátásokat is. A technológiai fejlődést endogén módon ábrázolja, amely lényegében a $\mathrm{K}+\mathrm{F}$ ráfordításoktól, illetve a technológiai haladást szolgáló múltbeli és aktuális beruházások szintjétől függ.

Az E3ME outputja magában foglalja a GDP felhasználási aggregátumait, az ágazati outputokat, a környezetkárosító kibocsátásokat, a munkaerő-piaci jellemzőket ágazatonként, a fogyasztói árakat, a jövedelemelosztási jellemzőket, valamint az energiaszektor legfontosabb jellemzőit országonként és a vizsgált országcsoportra globálisan. A modell ugyan hosszabb távra is elöre tud jelezni, de, mivel a modellösszefüggések idősoros (ökonometriai) becsléseken alapulnak, a struktúra valószínű változásai miatt az előrejelzések csak rövid, vagy középtávon tekinthetők relevánsnak.

\subsection{Hazai modellezési tapasztalatok}

Hosszú távon nemcsak az aktuális input-kombinációkban és a szinteken történő változások, de a földrajzi elosztása ezeknek az inputoknak szintén változik, és ez meg kell, hogy jelenjen, mint makroökonómiai jelenség. Marshall óta a közgazdászok tudatában vannak a térbeli externáliák termelésben játszott szerepével. A térbeli struktúrák makroökonómiai szerepe nemcsak elméleti jelentőséggel bír, mert a gazdaságpolitika alakításában is potenciálisan nagy jelentősége van. (Ennek példája az EU-ban folyó vita a Strukturális Alapok egyes tételeinek elosztásáról.)

A Varga és Schalk [2004] által kifejlesztett EcoRET egy olyan ökonometriai modell, melynek egyedi tulajdonsága, hogy beépíti a területi struktúrát a tradicionális makroökonómiai modellekbe a technológiai változások regionális blokkjai által. Segítségével a regionális pénzügyi támogatások elosztásának makroökonómiai hatásait lehet szimulálni. 
A modell létrejöttének hátterében az állt, hogy a makroszintü szabályozásba a regionális folyamatokat addig nem tudták integrálni. Az EcoRET modell a technológiai változást regionális dimenzióban vizsgálja, mivel annak meghatározó szerepe van az innováció terjedésében. A modell elméleti alapját az ún. új gazdaságföldrajz, a technológiai fejlődés és a tudásátszivárgások elméletei alkotják.

\section{A modell föbb tulajdonságai}

Feltételezzük, hogy a cégek költségminimalizáló magatartást követnek. Döntenek egy bizonyos output-növekedésről minden egyes időszakban, és minimalizálják a növekmény előállításának költségét. A cégek termelési függvénye vintage-capital formájú, melyben a tőkét egy putty-clay-nek tekintik, mely feltételezhetően egy ex-ante helyettesítés a tőke és a munkaerő között, de vannak rögzített ex-post részek, miután a tőkét beépítették. A termelés inputjai a tőke, munka és technológia. A munka- és a tőkekereslet levezethető a költségminimalizálásból. A kibocsátás függ a hazai és a külföldi kereslettől, éppúgy, mint a termelési költségektől, mint pl. a munkaköltség, a tőkehasználati költség és a technológia szintje. A munka és a tőke magasabb költsége megnöveli a termelési költségeket, míg a technológiai fejlődés csökkenti azokat. A munkások és a cég közötti egyezkedés határozza meg a béreket. A javak piacairól feltételezzük, hogy nem kompetitívek, ennek következtében a végtermékek ára áll az egységnyi tőke- és munkaköltségből plusz árrés. A végső kereslet függ a háztartások rendelkezésre álló reáljövedelmétől és az átlagos fogyasztási hajlandóságtól, a kormányzati kereslet egzogén a modellben.

\section{Földrajzi és technológiai fejlödés}

A legfőbb különbség az EcoRET és más makroökonómiai modellek között az, hogy a kínálatoldali kapcsolatokban képes a technológiát magyarázó változóként megjeleníteni. A technológiai változások adekvát modellezése igényli a térbeli dimenziók beépítését.

A technológiai fejlődés modellezéséhez történő közelítés fogalmi alapja az új gazdaságföldrajzi irodalomból, innovációs rendszerek irodalmából és az „új” endogén növekedéselméletből vezethető le. Az innovációs rendszerek irodalma hangsúlyt fektet arra, hogy az innováció rendszereinek, szereplőinek, kollektív cselekvésének eredménye a 
technológiai fejlődés. Egy innovációs rendszer nemcsak kutatási részlegekkel rendelkező innovatív vállalatok, beszállítók és vevők hálózatát foglalja magában, de számos intézményi tényezőt is, mint például egy közpénzből finanszírozott kutatás, vagy az iskoláztatás nemzeti rendszere, képzési és pénzügyi rendszerek. A térbeli közelség hozzájárulhat a tudás áramlásának elősegítéséhez az innovációs-rendszerek szereplői között.

Egy specifikus jellemzője a tudás közvetítésének megmagyarázza ezt a megfigyelést. A tudás mindig magában foglal egy bizonyos mértékü hallgatólagosságot, amely általában nagyon magas, amikor a tudás a fejlesztés szakaszában van. Ez a típusú tudás az, ami potenciálisan a legfontosabb az innovációban. A tudás térbeli átadásának hatékonysága közvetlenül köthető a kodifikáláshoz: míg a kodifikált tudás könnyen mozog nagy távolságokban is írásos formában (pl. tudományos értekezések, publikációk), a hallgatólagos tudás átadása sokkal komplexebb, a kommunikáció nem írásbeli formáira támaszkodik, amely személyes kapcsolatokat igényel.

Ha a tudás nem egyformán elérhető a tér minden pontján, a tudás létrejöttének helye és a tudás szétszóródásának jellemzői egy lényeges elemmé válhatnak abban, hogy megértsük a gazdasági növekedést. Ez megmagyarázza a mértékét annak, hogy melyik tudás-áramlások vannak földrajzi hatások közé szorítva, és ez különös figyelmet kapott a legújabb közgazdasági irodalomban. Nyilvánvalóvá vált az Egyesült Államok és Európa alapján az, hogy a tudás áramlása relatív szük földrajzi határok közé esik.

A technológiai változás az EcoRET modellben a tudástermelésen alapul. Ez alapján az új technológiák létrehozásának hatékonyságát nagymértékben befolyásolja a tudásátszivárgás. Feltétele, hogy a teljes tudásállomány hozzáférhető legyen földrajzi korlátozások nélkül.

\section{A modell struktúrája}

Az EcoRET négy fő blokkból áll. Az első a kínálati oldal blokk, amely tartalmazza a munkapiacot, megjeleníti az üzleti szektor tevékenységeit, kiemelve a termelést, termelékenységet, beruházást, foglalkoztatottságot, munkanélküliséget, termelési költségeket és az inflációt. A második a kereslet oldali blokk, amely meghatározza a legfontosabb magatartási kapcsolatot a háztartások, fogyasztás és a többi keresleti tényező között (kormányzati kiadások, külkereskedelem stb.) reál és nominál értékben. A harmadik a jövedelemelosztási blokk, amely meghatározza a magán és kormányzati jövedelmet (munka- 
és tőkejövedelem, profit), és a transzfereket a háztartások és a kormányzat között (adók, szociális juttatások és egyéb transzferek a szektorok között). A negyedik pedig a teljes tényező termelékenység blokk (TFP): a TFP regionális szintjén történő változásokat modellez - ez a regionális TFP szinten változik mint bizonyos tudáshoz köthető változók függvénye, úgy, mint ahogy a CFS méri például a fizikai infrastruktúra és az emberi tőke támogatását.

A hangsúly az EcoRET-nek azon elemein van, amelyek lehetővé teszik a makroökonómiai változókra való földrajzi hatás tanulmányozását. Ezek tartalmazzák a kínálat oldali technológiai hatásokat, a technológiai változás regionális modelljét, a főbb egyenleteket, amelyek hordozzák a makroökonómiai változókra való technológiai hatást, és tartalmazzák a kapcsolatot a regionális technológiai blokk és a makroökonómiai blokk között.

\section{Kinálat oldali hatások a technológiai fejlödésre}

A technológiai fejlődést a TFP tükrözi. Legújabb ökonometriai kutatások nyugat-német és USA-beli régiókra vonatkozóan mutatják, hogy az ipari struktúra, a tőkeállomány kora, agglomerációs hatások, innovációs potenciál, infrastruktúra és emberi erőforrások (a munkaerő képzettsége) mind kapcsolódnak a TFP-hez. Így az alapinfrastruktúrára és humánerőforrásokra fordított közkiadások növelik a tőke termelékenységét, és a munkaerő hatékonyságát, ezáltal növelve a TFP-t. Ez úgy működik, mintha a vállalatok hatékonyabb tőkét használnának költség nélkül, vagy pedig a felhasznált input-tényezők elérhetők lennének alacsonyabb termelési költségek mellett. Ezeket összekombinálva ezek a hatások növelik a versenyelőnyt, ami odavezet, hogy nő Magyarország vonzereje, ezáltal az FDI, és így felgyorsul a gazdasági növekedés.

A foglalkoztatásra való hatás nem egyértelműen következik belőle, bár a kibocsátásra való hatásnak és a jövedelmi hatásnak elegendően nagynak kell lennie, hogy ellensúlyozni tudja a csökkenő foglalkoztatottságot. A növekedésre való hatása egyértelmüen pozitív. A megközelítés előnye az, hogy megfelelő módon ragadja meg a csatornákat, amin keresztül még az ideiglenes kínálat oldali orientációjú programoknak is megvan a kívánt tartós hatása. Egy ideiglenes pénzügyi támogatás megnöveli a TFP-t, és javítja a termelékenységet, és megnöveli az egy före eső jövedelmet egy tartósan magas szintre, míg a keynesiánus kereslet oldali hatás a kibocsátásra és jövedelemre nem bizonyul tartósnak. 
Az EcoRET fejlesztésének és gyakorlati alkalmazásának lényeges eleme volt egy olyan változónak a létrehozása, amelyik méri a technológiai változást. A tőkében, munkában és technológiában történt változások gazdasági növekedésre való hatásának elkülönítése után a technológia szintjét reziduálisként mérik a másik két termelési tényező hatásának figyelembe vétele után. Ezt a reziduumot TFP-nek hívják. A regionalizált technológiai változás modelljének választása azt mutatja, hogy a TFP értékek minden egyes térbeli egységre számszerüsítve vannak. A technológiában történt változások TFP növekedési rátával mérhetőek.

A technológiai egyenlet a Romer-féle technológiai változáson alapul. A romeriánus modellben a teljes tudásállományról azt feltételezik, hogy mindenféle földrajzi akadály nélkül hozzáférhető, bár a legújabb empirikus tudásátszivárgásról szóló irodalom elegendő ellenbizonyítékot szolgáltat. Egy jelentős része a tudásáramlásoknak térben korlátok közé szorul a nagymértékü hallgatólagosságnak köszönhetően, ami az új tudományos-technológiai tudásban figyelhető meg.

A regionális technológiai egyenlet becslése az 1998-2002 közötti időszakra és az összes magyarországi megyére vonatkozó adatokon alapul. Az empirikus modell a következő alakban írható föl:

TFPGR $=-20,90+0.001895 * \mathrm{KNAT}(-2)+1.51 \mathrm{E}-0.6 * \mathrm{RD}+0.065393 * \mathrm{KIMP}+1.93 \mathrm{E}-$ 0.6*INFRAINV + 3.79E-0.6*HUMCAPINV - 0.259222*DUM98 + 0.081378*DUMGY,

ahol TFPGR a TFP éves növekedési rátája, KNAT a rendelkezésre álló technológiai tudás (földrajzi korlátozás nélkül hozzáférhető), RD a kutatás-fejlesztésre költött magán és állami kiadások összege (ráfordított pénzösszegben mérve), KIMP az importált technológiák (az FDI aránya a teljes magánberuházásokhoz), INFRAINV a fizikai infrastruktúrába történő beruházás, HUMCAPINV pedig a humántőkébe történő befektetés.

A becsült helyi RD paraméter következetesen szignifikáns és nagysága mindvégi stabil a modellben. Ez azt mutatja, hogy még a technológiai import és földrajzilag nem korlátozott 
hazai tudásáramlás figyelembevétele után is a helyi tudásátszivárgások valóban szerepet játszanak a technológiai változásban.

A helyhez kötött tudásátszivárgások viszonylag kis hatása nem meglepö, tekintettel a $\mathrm{K}+\mathrm{F}$ kiadások viszonylag alacsony részesedésére a magyar GDP-n belül és a tényre, hogy az ország innovációs rendszere még mindig átmeneti.

Az igényes módszerek, amelyeket gyakran használnak ökonometriai becslésekhez és hipotézisvizsgálathoz, vagy nem megfelelőek vagy megvalósíthatatlanok voltak az alacsony számú rendelkezésre álló megfigyelés következtében. Ezért néhány viselkedési egyenlet parametrizálása az indirekt kalibrálás módszerével kellett, hogy történjen.

A technológiával összefüggö föbb makroökonómiai egyenletek

Feltételezés, hogy a vállalatok döntése a termelés szintjéről és helyéről a keresleti tényezőktől és a költségfeltételektől függ. A kínálati oldalon minden tényező a termelési költségek befolyásolásán keresztül hatással van a hazai cégek tőke-és munkakeresletére és ezáltal a termelés szintjére is.

\section{A TFP blokk összekapcsolása az EcoRET többi részével a gazdasági szimulációk során}

Az EcoRET makroökonómiai blokkjai időtartamon becsültek, míg a TFP blokk regionalizált. Éppen ezért a különböző regionális szintű gazdaságpolitikai lépések által okozott TFP növekedési ráta változások összekapcsolása az EcoRET többi részével bizonyos kihívást jelentett. A probléma megoldásában az agglomeráció és technológiai változás terén végzett elméleti és empirikus kutatásokra támaszkodtak. A technológiai fejlődés és az agglomeráció között pozitív kapcsolat áll fenn.

A TFP blokkban kiszámolható a TFP növekedési rátában történt változás, amely a gazdaságpolitikai beavatkozások következménye az egyes megyékben. Az agglomerációs hatásnak a technológiai változásban történő figyelembevétele miatt a kapott értékeket súlyozták a regionális foglalkoztatottság változójával, amely tükrözi a régió gazdasági méretét. A regionális TFP blokk egy rendkívül jó becslést ad az EcoRET makroökonómiai blokkjából becsült nemzeti TFP növekedési rátára vonatkozóan. A regionális 
foglalkoztatottsággal súlyozott TFP növekedési ráták igen jó közelítést adtak a nemzeti TFP szintekre.

A 2004-es évre a nemzeti TFP szintet a következő módon számolták:

$\mathrm{TFP}=\mathrm{TFP}_{-1} \mathrm{e}^{\mu} \mathrm{e}^{\mathrm{DNTFPGR}}$,

ahol a TFP a nemzeti TFP szint, $\mu$ a makroökonómiai blokkban szereplő technológiai növekedési ráta becsült szintje, és DNTFPGR pedig a nemzeti TFP növekedési rátájában történő változás (a regionális TFP növekedési ráták súlyozott átlagaként számolva).

Így a fenti a kulcsegyenlet a TFP blokk és a modell többi részének összekapcsolásában. A szimulált új nemzeti TFP érték a fenti egyenletben átvezeti a TFP blokk eredményeit a makroökonómiai blokkba.

Összegzés

A makroökonómiai teljesítményre való földrajzi hatások a közgazdaságtan legfrissebb kutatási területéhez tartoznak. Az új gazdaságföldrajz megjelenésével és ennek az endogén gazdasági növekedéssel történő integrálásása felé tett első lépésekkel a lehetőség a gazdaságot érő földrajzi hatások kutatására jelentősen növekedett.

\subsection{Esettanulmányok}

Az esettanulmányok többsége abból indul ki, hogy a kohéziós politika legfontosabb célja, hogy elősegítse a regionális konvergenciát az unión belül. Ugyankor a kiszorítási hatás, gyenge elosztási hatékonyság, és a járadékvadászat csökkenthetik, vagy teljesen meg is szüntethetik ezt a pozitív hatást. Ennek megfelelően igen gyakori annak az alapkérdésnek a vizsgálata, hogy a kohéziós politika valóban képes-e a régiók közti jóléti különbségek csökkentésére. A válaszok természetesen eltérőek, és azt sem szabad elfelejteni, hogy egy rövidebb lélegzetvételü elemzés csak néhány mutatóra támaszkodhat a fenti kérdés megválaszolásakor.

Számos esettanulmány született, melyekben egy-egy projektet értékeltek. Néhány közülük a támogatások elköltésének módjára helyezte a hangsúlyt, mások a makrogazdasági 
következményeket vizsgálták. Az esettanulmányokról jó áttekintést ad Ederveen [2002] Funds and Games címü tanulmánya, a továbbiakban ezek közül is ismertetünk néhányat.

Huggins [1998] tanulmánya a második célkitűzés keretein belül Dél-Wales-ben végrehajtott programok sikerességét mutatja be. Részletes leírást tartalmaz a régió társadalmi-gazdasági helyzetéről, a kohéziós politika által finanszírozott programokról stb. A kohéziós politikai programokat a megteremtett munkahelyek száma és a megépített utak hossza segítségével értékelte.

Lolos [1998] az 1980-as és 1990-es évek makrogazdasági és strukturális politikájának eredményességét vizsgálta Görögország és Portugáliára vonatkozóan, és arra az eredményre jutott, hogy a kohéziós politika Portugáliában sokkal eredményesebb volt.

Az Európai Bizottság 1999-es tanulmányában ${ }^{22}$ a kohéziós politika pozitív hatásáról számolt be. A kohéziós alap programjai, melyeket értékeltek, szignifikánsan járultak hozzá a gazdasági növekedéshez és a foglalkoztatottság emelkedéséhez egyaránt.

Ernst\&Young [1996] egy kutatást végzett a második célkitűzés alá eső régiókra vonatkozóan az 1989-93-as kohéziós politikai programok hatásainak értékelésére. Eredményeik alapvetően esettanulmányokon alapulnak, melyek a projektet támogatóival készített interjúkat is tartalmaznak. Mivel erre a célkitüzésre nyújtott támogatások elsősorban arra irányultak, hogy a munkapiaci strukturális változások miatt megszünő munkahelyek helyett újakat teremtsenek - és így a hajógyárak, bányák bezárása következtében munkanélkülivé váló embereknek újra munkát biztosítsanak -, ezért a támogatások hatását a foglalkoztatottsággal lehet mérni. Méréseik alapján 6 milliárd euró, mely a második célkitüzés keretében érkezett a közösségi forrásokból, mintegy bruttó 850 ezer állást teremtett, ami nettó 450 ezer munkahelyet jelentett. A különbség a nemzeti regionális támogatások kiszorulásának és a nem támogatott vállalatok és foglalkoztatottak kiszorításának tulajdonítható. A hazai társfinanszírozást is hozzáadva az egy létrehozott új munkahelyre eső költség 42 ezer euró. A munkanélküliség pedig 0,8 százalékponttal lett alacsonyabb, mintha nem érkezett volna támogatás. Az Európai Bizottság $^{23}$ [2001] szintén felbecsülte ezeket, és arra a megállapításra jutottak, hogy 1994-96-

\footnotetext{
${ }^{22}$ European Commission [1999]: Better management through evaluation, Mid-term review of Structural Funds programmes: Objectives 1 and 6.

${ }^{23}$ European Commission [2001]: Working for the regions, Europe on the move.
} 
os periódusban 33 ezer euróba került egy munkahely létrehozása, míg az 1997-99-es időszakban 24 ezerbe.

Spiridonovs [2011] az uniós támogatással megvalósult infrastrukturális beruházások eredményességét vizsgálta. Elemzésében 88 lettországi projektet vizsgált meg, amelyek többsége az ivóvízellátáshoz vagy a szennyvízkezeléshez kapcsolódó közösségi beruházás. A szerző felhívja a figyelmet arra, hogy mennyire nehezen számszerüsíthető az ilyen programok hatékonysága vagy fenntarthatósága. Cikkében végül egy olyan mérőszámot javasol, melynek alapja az, hogy hogyan alakul az adott közszolgáltatásra a háztartások által fordított kiadás az összes háztartási kiadás százalékában. Amennyiben ez csökken, úgy a mutatószám a hatékonyság illetve a fenntarthatóság javulását jelzi. Az eredmények azt mutatják, hogy a projektek befejezését követő években a vizsgált programok átlagában ez a mutató kedvező irányba mozdult, azaz eredményesnek tekinthetők a megvalósult beruházások.

Koschatzky és Stahleckker [2010] a regionális politikával kapcsolatos új kihívásokra hívja fel a figyelmet, elsősorban az innovatív gazdasági környezet megteremtésére fókuszálva. Az esettanulmány két német tartomány, Szászország és Bajorország innovációs stratégiáját hasonlítja össze. A szerzők kiemelik, hogy két gyökeresen eltérő helyzetben lévő régióról van szó: míg Szászországra - a kelet-német tartományok egyik pozitív példájaként - a fokozatos felzárkózás és a sikeres kovergencia a jellemző, addig Bajorország Németország egyik leggazdagabb és leginnovatívabb tartománya. Ebből adódóan a lehetséges források köre is különböző. Szászország elsősorban az unió kohéziós alapjaiból jogosult számottevő forrásokra, Bajorország pedig a lisszaboni stratégia keretében számíthat - jóval kisebb összegü - támogatásokra. A német szerzőpáros megállapítja, hogy mindkét régió sikeres innovációs politikát folytatott az elmúlt években, ami elsősorban azzal magyarázható, hogy a helyi döntéshozók megfelelő ,policy mix”-et alkalmaztak, azaz a helyi sajátosságok figyelembe vételével alakították ki a regionális, illetve azon belül az innovációs politikájukat.

Néhány kutató azon a véleményen volt, hogy az egyéni projekteket egy regionális gazdasági modellbe illesztve az externális hatásokat jobban számszerüsíteni lehet. Venables és Gasiorek [European Commission, 1999] ${ }^{24}$ ezért egy olyan általános egyensúlyi modellt hoztak létre, amelyben több régió szerepel, melyeket egy közlekedési hálózat kapcsol össze. A modell

\footnotetext{
${ }^{24}$ European Commission [1999]: The socio-economic impact of projects financed by the
} 
elméleti alapjául az új gazdasági földrajz szolgált. Hat projektet vizsgáltak Spanyolország, Portugália, Görögországban és Írországban, és arra a következtetésre jutottak, hogy a kohéziós politika keretein belül nyújtott uniós támogatások jelentős regionális gazdasági előnyökhöz vezetnek, melyeket az agglomerációs externáliákból adódó növekvő skálahozadékot okoznak.

Számos szerző szkeptikus volt az alapok hatásával kapcsolatban. Bachtler és Turok [1997] több szakértővel közösen készítettek egy esettanulmányokat tartalmazó könyvet, melyben összesítették tapasztalataikat a kohéziós támogatásokról, különböző országokra és régiókra egyaránt. Véleményük szerint a hatásokat igen nehéz számszerüsíteni, de nagyon valószínűnek tartják, hogy azok mértéke elhanyagolható volt.

Bachtler és Taylor [1996] pedig az EU intézmények projektértékelésein alapuló kutatást végeztek, az 1994-99-es programozási időszakra vonatkozóan. Az eredményeket nem számszerüsítették, azonban több kritikus észrevételük is volt: a projektek gyakran mellőzik a racionalitást, továbbá nehéz az EU kohéziós politikája által támogatott stratégiát a szélesebb gazdaságpolitikai környezettel összhangba hozni, továbbá az elosztási rendszer túlságosan bonyolult, ezért nem elég hatékony.

Kamps, Leiner-Killinger és Martin [2009] a kohéziós politika ciklikus hatásait vizsgálta. Cikkükben részletesen megvizsgálják az új tagállamok és a korábban nagymértékben támogatott országok (Görögország, Spanyolország, Portugália, Írország) közötti különbségeket a felhasznált transzferek mennyisége és szerkezete szempontjából. Megállapítják, hogy számos új tagállamban annak ellenére túlfütötté vált a gazdaság a válság előtti időszakban, hogy lényegesen kevesebb EU forráshoz jutottak, mint a fejletlenebb régi tagállamok a 90-es években. Elsősorban a munkabérek túlzott növekedése okozta a problémákat a balti államokban és Romániában, míg Lengyelországban és Szlovákiában az inflációs ráta emelkedett a kívánatos szint fölé. Mindezeket figyelembe véve a szerzők azt javasolják, hogy az uniós támogatások felhasználása során - változatlanul fenntartva, hogy a legfontosabb cél a gazdasági konvergencia - célszerü rövid- és középtávú stabilizátorként is használni azokat. Azaz a gyors növekedés időszakában célszerű előtérbe helyezni azokat a 
programokat, melyek nem növelik számottevően a hazai keresletet, míg a gazdasági ciklus leszálló ágában érdemes keresletösztönző projekteket indítani.

Dumciuviene [2009] kiemeli, hogy az EU-transzferek alapvetően szupranacionális döntések eredményeként kerülnek a kedvezményezettekhez. Megállapítja ugyanakkor azt is, hogy ezek csak akkor lehetnek hatékonyak, ha a nemzeti gazdaságpolitikák is segítik a pozitív hatásokat. Ezek közül elsősorban olyan nem-pénzügyi elemeket jelöl meg, mint a munkaerő-piaci szabályozás vagy a beruházási környezet. Ugyanakkor fontosnak tartja a $\mathrm{K}+\mathrm{F}$ kiadások növelését is, ami összehangolt nemzeti és nemzetek feletti döntéshozatalt igényel. A szerző két évvel későbbi cikkében ${ }^{25}$ a regionális különbségek csökkentésének fontossága mellett érvel. Megállapítja, hogy bár az uniós támogatások jelentősen hozzájárultak Litvánia gyors felzárkózásához a 2004-2006 közötti időszakban, eközben csökkent a foglalkoztatottság, és erősödtek a munkaerőpiac strukturális feszültségei, mindez pedig rontja a hosszú távú növekedési potenciált. Ennek okát a területi egyenlőtlenségek növekedésében látja, ami szerinte a Strukturális Alapok forrásainak a korábbiaktól eltérő szerkezetü felhasználásával orvosolható. Értékelése szerint a mezőgazdaság és az építőipar nagyobb arányú támogatása adhatna lendületet a leszakadó térségek gazdaságának.

\section{6 Ökonometriai becslések}

Általánosságban elmondható, hogy a modellszimulációk az alapok potenciális hatását számszerüsítik, míg az ökonometriai tanulmányok a tényleges hatás becslésére alkalmasak. Ennek megfelelően a modellek szerint a strukturális támogatások szignifikánsan és pozitívan hatnak a keretbe bevont országok gazdasági növekedésére, erőteljesen segítve a konvergenciát. Az ökonometriai becslések szerint azonban az alapok hatása jó esetben is csak elhanyagolható volt a múltban, sőt nemegyszer a konvergenciára gyakorolt negatív hatást mutatnak ki.

Az ökonometriai tanulmányok két csoportra oszthatók: vannak, amelyek indirekt bizonyítékokat keresnek a kohéziós politika növekedésre gyakorolt hatására vonatkozóan, másik csoportba pedig azok kerülnek, melyek közvetlenül mérik annak nagyságát, hogy a

\footnotetext{
${ }^{25}$ Lásd: Dumciuviene [2011]
} 
kohéziós támogatások mekkora részben járultak hozzá a növekedéshez. Az ex-post ökonometriai elemzések kiegészítik a modellszimulációkat, melyek ex-ante elörejelzéseket adnak hatások értékelésére. Az irodalomban fellelhető ökonometriai tanulmányok többségéről elmondható, hogy általában egyetlen regressziós egyenletet becsülnek, melynek magyarázó változói között szerepeltetik az uniós transzferek mértékét is.

Több ökonometriai tanulmány közvetlenül méri a támogatások hatását a gazdasági növekedésre. Néhány közülük a konvergenciára vonatkozó hipotézis teljesülését igazolta. Fayolle és Lecuyer [2000] az 1986-96-os periódusra vizsgálta az európai régiók gazdasági növekedését. A régiók gazdasági teljesítménye és az uniós forrásokhoz történő hozzáférés közti korrelációt vizsgálták, majd regressziót becsültek, amelyet kiegészítettek az egyes országokat jelentő dummy változókkal. Eredményeik alapján a kohéziós politika hatással volt a gazdasági teljesítményre, azonban ez a hatás nagy mértékben függött attól, hogy az adott régió melyik országhoz tartozott. Fuente [2002] hasonló kérdéskört elemzett, de jóval szükebb kontextusban: csak a kohéziós támogatások hatását vizsgálta az első célkitüzés alá eső spanyol régiókban az 1994-99-es időszakra vonatkozóan. Egy becsült, kínálatorientált modellt alkalmazott regionális és panel adatokra. Eredményei alapján Spanyolországban jelentős hatása volt az Európai Unióból érkező transzfereknek, hatásukra a kibocsátás éves növekedési ütemét mintegy egy százalékponttal emelkedett, a foglalkoztatottság üteme pedig 0,4 százalékkal lett magasabb évente a vizsgált periódusban. Az 1994-2000 időszakot tekintve mintegy 300 ezer új munkahely jött létre, és a gazdaságilag elmaradott (és ezáltal nagyobb támogatásban részesülő) régiók lemaradása mintegy 20 százalékkal mérséklődött az ország többi részéhez viszonyítva.

Garcia-Solanes és Maria-Dolores [2001] egy standard neoklasszikus növekedési egyenletet becsültek, ahol a GDP növekedési ütemét az egy före jutó GDP induló szintje és a kohéziós támogatások egy före eső értéke magyarázta. Számításaik során gyenge, de szignifikáns kapcsolatot találtak a transzferek mennyisége a növekedés üteme között. Cappelen et al. [1997] ezzel szemben egy adott régió gazdasági fejlődősének alakulását alapvetően a technológiai ugrásokkal magyarázzák. A technológiai ugrások három tényezővel függenek össze: az innovációs tevékenységgel, a máshol kifejlesztett technológiák kihasználásának lehetőségével - ezt nevezik a szerzők diffúziónak - és azon képességekkel, melyek lehetővé teszik e lehetőségek kihasználását. Erre az elméleti bázisra építkezve becsülték modelljüket, melyet az 1980-97 közötti időszakra futtattak. Eredményeik alapján az Unió regionális 
támogatásainak pozitív hatása az első periódusban sokkal kisebb volt, mint 1989-97 között. Egy kisebb mintán is megismételték az előző becslést, mely nem tartalmazta Görögországot, Spanyolországot és Portugáliát. Ekkor az 1980-as évekre vonatkozóan nem jelentkezett pozitív hatás, a két periódusbeli hatás közti különbség pedig nagyobbnak bizonyult, mint az első esetben.

Boldrin és Canova [2001] vizsgálataik alapján arra a megállapításra jutottak, hogy az EU regionális politikája és a gazdasági növekedés ösztönzése között csak igen gyenge a kapcsolat. Szerintük a sikeres bővítési folyamatok érdekében a regionális támogatási rendszer felülvizsgálata és átalakítása szükséges, mert jelenleg a strukturális és kohéziós alapok olyan céloknak alárendelten müködtek, melyeknek nem elsődleges célja a gazdasági növekedés és konvergencia elősegítése. Stoianov [2003] szintén pesszimista képet vázol a strukturális és kohéziós alapok várható hatásairól. Szerinte több tényező is rontja az uniós támogatások hatékonyságát. Egyrészt a források egy részét közösségi fogyasztásra fordítják beruházások helyett, ami gyakran összefügg az addicionalitás elvének megsértésével: a régiók és a tagállamok kormányzatai hajlamosak elhanyagolni egyéb beruházásaikat, és a felszabaduló forrásokat közvetlen fogyasztásra költeni. Másrészt a vitathatatlanul hasznos beruházásoknak is lehetnek negatív hatásaik. Például az infrastruktúra fejlesztése nemcsak az adott régió exportlehetőségeit bővíti, hanem a külpiaci versenytársak helyzetét is megkönnyíti, és így akár csökkentheti is a helyi iparágak versenyképességét. A szerzők szerint előfordulhat az is, hogy minden jó szándék ellenére sem optimális szerkezetben történik a beruházási projektek kiválasztása. Gyakori jelenség a helyi és regionális vezetők alkalmatlansága, járatlansága a nagyobb projektek költség-haszon elemzésében, lebonyolításában. Továbbá az elmúlt időszakban gyakran tapasztaltak értékelési torzítást a költség-haszon elemzésekben, ugyanis a régiók az adott projekt megvalósításában érdekeltek, így hajlamosak az előnyök felülbecslésére és a költségek alultervezésére. A támogatások negatív hatása lehet az is, hogy bizonyos esetekben csökkentik a munkaerő mobilitását, mert mérsékelhetik az adott régióból történő elvándorlási hajlamot. A szerző kitér az Európai Unió 2004-es bővítése előtt támogatott tagországok (föleg Görögország, Spanyolország, Portugália), illetve az újonnan csatlakozott kelet-közép-európai országok közötti különbségekre is. Az utóbbi térségben nagyobbak a regionális egyenlőtlenségek, a nemzeti regionális fejlesztési politikák pedig meglehetősen fejletlenek. További különbség adódik a földrajzi elhelyezkedésből: a korábbi kohéziós országok a gazdaságilag fejlettebb tagállamokhoz képest inkább periferikus elhelyezkedésűek, míg az újonnan csatlakozott államok közelebb vannak a centrumhoz. Ebből 
következően az előbbiek esetében a jelentősebb közlekedési infrastrukturális beruházások elsősorban a centrum gazdasági vérkeringésébe történő minél erősebb bekapcsolódás tették lehetővé, míg az újonnan csatlakozott országok esetében a hasonló beruházások egyben fokozzák az unió többi régiója által az adott térségre gyakorolt kompetitív nyomást is. ${ }^{26}$ Farole et al [2009] is hangsúlyozzák a gazdaságföldrajzi adottságok és ezzel összefüggésben a szállítási költségek jelentőségét a kohéziós politika sikerességében, ugyanakkor felhívják a figyelmet az egyéb kereskedelmi költségek hatásaira az uniós támogatások hatékonyságát illetően, és ebben a vonatkozásban is kiemelkedő jelentőséget tulajdonítanak az intézményrendszer hatékonyságának.

Ederveen et al. [2003] meglehetősen szkeptikus a strukturális alapok növekedésre gyakorolt hatásait illetően. A szerzők szerint a kedvező hatások a legtöbb esetben azért nem jelentkeznek, mert az egyes tagállamokban elégtelenül müködnek az uniós támogatásokat kezelő intézmények. A sikeres abszorpció feltételeként említik még a külkereskedelmi nyitottságot és az alacsony a korrupciós indexet. Ederveen és szerzőtársai az addicionalitás teljesülését is vizsgálták az 1989-93 közötti periódusra. Eredményeik alapján 1 euró közösségi támogatás 17 cent olyan nemzeti regionális fejlesztési beruházást szorít ki, ami egyébként (a közösségi támogatás hiányában) megvalósult volna. Az Európai Bizottság [2004] jelentése alapján azonban teljesült az addicionalitás elve az 1994-2006-os periódusban az uniós tagországok esetében. Az eltérés oka lehet egyrészről, hogy különböző időszakokra vonatkozó számításokról van szó, másrészt az addicionalitás fogalmának eltérő alkalmazása. Ederveen et al. [2006] újabb számításokkal támasztják alá korábbi véleményüket, miszerint az EU kohéziós politikája alapvetően hatékonytalan, és alkalmatlan a szegényebb tagállamok konvergenciájának elősegítésére. Bradley és Untiedt [2008] azonban vitába száll ezzel a véleménnyel, azzal érvelve, hogy az Ederveen és társai által alkalmazott keresztmetszeti és panel egyenletek rosszul specifikáltak, az általuk használt adatbázis nem megfelelő, sőt az egész módszertan alkalmatlan a feltett kérdések megválaszolására. Dall'erba et al. [2009] térökonometriai modellt alkalmaztak, és számítási eredményeik Ederveenék álláspontját erősítik meg. A szerzők ezt elsősorban a növekvő skálahozadékok jelenlétével magyarázzák ilyen körülmények között ugyanis kifizetődőbb a nagyobb és fejlettebb régiókba invesztálni. Ugyanakkor azt is megemlítik, hogy még számos potenciális magyarázó változó alkalmazása

\footnotetext{
${ }^{26}$ Boldrin és Canova [2001] és Stoianov [2003] tanulmányát idézi még: MNB [2006].
} 
jöhet szóba ilyen és hasonló modellek alkalmazásakor, tehát csak a későbbi kutatások eredményeként lehet majd igazán megbízható eredményekre számítani.

Percoco [2005] az olaszországi elmaradott régiókra vonatkozóan becsülte meg az 1994-99-es támogatási időszakban beérkező alapok növekedésre gyakorolt hatásait, Fuente [2002] kínálat-oldali megközelítését átvéve. A Strukturális Alapok kiadási következtében jelentős volatilitás volt megfigyelhető a vizsgált hat régió növekedési ütemében. Az alapok 1994-2005 közötti, növekedésre gyakorolt kumulatív hatását hat régióra vonatkozóan vizsgálta meg, és ez a Strukturális Alapok okozta többlet-növekedés 3,96 és 6,13 százalék között volt, mely igen nagy eltérést jelent a régiók közt. Ezt a különbséget a támogatások eltérő szerkezetben történő felhasználásával magyarázta. Hasonló vizsgálatot végzett Bachtler és Gorzelak [2007], de ők valamennyi fejletlen régiót bevonták a vizsgálatba, és az elemzést kiterjesztették a 2000-2006-os programozási időszakra is. Több modell eredményeit is összevetették, köztük a HERMIN és QUEST modellek outputjait is. A HERMIN bizonyult a legoptimistábbnak, míg a QUEST jóval kisebb addicionális hatásokat becsült. Általános tendencia volt az is, hogy a 1994-99-es időszakban kedvezőbb eredmények adódtak, mint a későbbiben.

Ionescu és Tudor [2011] az elhúzódó pénzügyi és gazdasági válság körülményei között becsülte meg a Kohéziós Alapok makrogazdasági hatásait a román gazdaságra vonatkozóan. Ehhez a HERMIN modell román változatát, a HEROM-ot használták fel. Magát a modellt nem a szerzők fejlesztették ki, csak a legfrissebb eredményeket közlik a tanulmányban, emiatt szerepeltetem ezt a forrást az ökonometriai becslések között. Számításaik szerint az uniós pénzek jelentősen növelik a román gazdaság növekedési ütemét a 2020-ig terjedő időszakban. A kibocsátási többlet elsősorban az ipari szektorban jelentkezik majd, ahol akár 500 ezerrel is nőhet a munkahelyek száma. A mezőgazdaságban azonban az uniós támogatásoktól függetlenül mindenképpen csökken majd a munkaerő-kereslet, így csak kismértékben nőhet a foglalkoztatás. Az EU-transzferek számottevően növelik a hazai keresletet, aminek hatására átmenetileg megugrik az import, így a következő néhány évben gyorsabban bővülhet, mint az export.

Padam, Ehrlich és Tenno [2010] a balti országokban 2007 és 2013 között EU-támogatással végrehajtott illetve tervbe vett környezetvédelmi beruházásokat elemzik a hosszú távú fenntarthatóság és hatékonyság szempontjából. A három ország együttesen közel 15 milliárd eurónyi uniós transzfert hívhat le a most futó programozási időszakban, aminek nagyjából 18 
százalékát fordíthatják környezetvédelemre. A szerzők számításaik során költség-haszon elemzést végeztek, melynek során a hasznokat a „willingness to pay” módszerrel becsülték. Megemlítik azonban azt is, hogy a természeti környezet olyan komplex erőforrás, hogy célszerü lehet alternatív módszertant is alkalmazni. Erre az Esty és szerzőtársai [2008] által kidolgozott Környezeti Teljesítmény Indexet javasolják. Mindkét módszerrel arra a következtetésre jutottak, hogy távolról sem optimális a környezetvédelmi beruházásokkal kapcsolatos döntéshozatal. Egyrészt az ideálisnál kevesebbet fordítanak erre a területre, másrészt pedig a belső arányokon is módosítani kellene. A kutatók szerint például feleslegesen sokat költenek ivóvíz-beruházásokra, miközben jóval több erőforrást igényelne a biodiverzitás megőrzése vagy a természeti erőforrások (például termőföld) állapotának megörzése. Az uniós források elosztásának anomáliáit boncolgatja Bodenstein és Kemmerling [2011] is, akik arra a következtetésre jutnak, hogy támogatásra érdemesített régiók kiválasztása számos esetben nem az eredeti célkitüzések mentén történik, sőt egy választási modell segítségével még azt bemutatják, hogy egyes deklarált céloknak épp az ellentéte valósul meg a tényleges forráselosztás során. A szerzők szerint ennek az lehet az oka, hogy a politikai szempontok és/vagy a gazdagabb régiók sikeres lobbi tevékenysége gyakran felülírja a közgazdasági racionalitást.

Az ökonometriai tanulmányok általában pesszimistább eredményt adnak az alapok hatásait illetően, mint a legtöbb modellszimuláció. Az ökonometriai modellekkel a támogatások tényleges hatásait próbálják becsülni, szemben a modellszimulációk potenciális számszerüsítéseivel, továbbá nem feltételezik a beruházások produktivitását, kiszorítási hatás hiányát és az addicionalitás teljesülését. Az ökonometriai kutatások gyenge pontja azonban az adatok szükössége és rossz minősége. Sok esetben nem áll rendelkezésre megfelelő részletezettségü, regionális szintü adatbázis. A rendelkezésre álló adatsorok viszont nem minden esetben tartalmaznak megfelelő hosszúságú idősorokat, ezáltal megnehezítve a strukturális alapok hosszú távú hatásainak számszerüsítését. Az ökonometriai becsléseknek ezek igen nagy hátrányai, amelyek akár ellensúlyozhatják az előnyöket, azonban nehéz lehet számszerüsíteni az arányokat. 


\section{Hosszú távú modellek elméleti alapjai és a nemzetközi modellépítési tapasztalatok}

Az eddigiekben áttekintettem az EU-transzferek eredményességére illetve makrogazdasági hatásaira vonatkozó legfontosabb publikációkat, a dolgozat későbbi fejezetei pedig már saját eredményeket tartalmaznak. Mivel azonban ezek a számítások egy közép- és hosszú távú előrejelzésekre alkalmas makroökonómiai modell segítségével készültek, azok közlése előtt mindenképpen szükséges a hasonló modellekkel kapcsolatos irodalom áttekintése. Ezt tartalmazza ez a fejezet.

Az alkalmazott modell leírását tehát a következő fejezet tartalmazza, azt azonban már most szükségesnek tartom jelezni, hogy egy már korábban létező modell részletesen átdolgozott verzióját használtam. Ezt a korábbi verzió volt az ECO-TREND modell, amelyet munkatársaimmal többször is publikáltunk. ${ }^{27} \mathrm{~A}$ negyedik fejezetben modell részletes bemutatása során arra is kitérek majd, hogy a modell mennyiben változott a korábbi verziókhoz képest, valamint a saját hozzájárulásom mértékét is igyekszem majd feltüntetni, bár csapatmunka esetében mindig nehéz a pontos arányok meghatározása.

Az ECO-TREND modell kialakításakor az volt a legfontosabb célunk, hogy lehetővé váljon a gazdaság hosszú és középtávú folyamatainak vizsgálata. Erre szükség lehet egy felzárkózási pálya elemzésekor, de akkor is, ha olyan nagy ívü döntések hosszú távú hatásait szeretnénk számszerüsíteni, mint az EU-csatlakozás vagy az euró magyarországi bevezetése.

Ilyen esetekben szükségessé válhat az endogén technikai fejlődés megjelenítése a modellben. Ez alatt azt értjük, hogy egy adott időszak gazdasági folyamatai befolyásolják a későbbi fejlődési lehetőségeket, konkrétan a termelési függvény paraméteré(ei)t. Emellett természetesen a tőkeállomány nagysága is függ a korábbi időszakok beruházási döntéseitől. Így létrejön egyfajta visszacsatolás, a kapacitások szükössége a beruházási tevékenység fokozására ösztönöz, aminek hatására növekszik a kínálat, és helyreáll az egyensúly. Modellünkben egyelöre csak az utóbbi hatásmechanizmus jelenik meg, a termelési függvény

\footnotetext{
${ }^{27}$ Lásd: Cserháti-Erni-Keresztély [2004], Keresztély [2004] iletve Cserháti-Keresztély-Varga [2007]
} 
paramétereire felírandó egyenletek specifikálása a modellfejlesztés következö fázisában valósul majd meg.

\subsection{Az endogén növekedési elméletek helye a közgazdasági elméletek történetében}

\section{A neoklasszikus növekedési modell}

Az endogén növekedéselméletek bemutatása elött szükséges egy rövid áttekintést adni azokról a növekedési modellekről, amelyek azok kiindulópontjául szolgáltak, illetve amelyekkel vitába szálltak.

A modern közgazdaságtan első növekedési modellje Harrod[1939] és Domar[1946] nevéhez füződik, akiket azonban igen hamar követtek a neoklasszikus közgazdászok. Neoklasszikusnak nevezzük azokat a tőkeakkumulációs növekedési modelleket, amelyek olyan termelési függvényt tételeznek fel, amelyben a tőke és a munka folytonosan, minden határon túl egymással helyettesíthetők, továbbá a termelési függvény első fokú homogén, és érvényesül a csökkenő hozadék elve. Egymástól függetlenül, lényegében egy időben, ilyen modellt dolgozott ki Solow[1956] és Swan[1956], ezért Solow-Swan modellnek, vagy gyakrabban csak Solow-modellnek is szokták nevezni ezt a típusú modellt.

Az fent említett feltevések mellett a nemzetgazdaság termelési függvénye az alábbi szerint írható fel:

$$
Y=F(K, A L),
$$

ahol $Y$ a nemzetgazdasági kibocsátás, $K$ a tőkeállomány és $A L$ a hatékony létszám (az $A$ az a megtestesült technikai haladás, amely hozzásegít a hatékonyabb termeléshez).

A termelési függvény egyszerübb formája:

$$
y=f(k)
$$


ahol $y=Y / A L$ (az egy főre vagy munkaegységre jutó jövedelem) és $k=K / A L$ (az egy före vagy munkaegységre jutó tőke).

A $t$-ik időpont kibocsátását az adott időpontban felhasznált hatékony munka és tőke aránya határozza meg:

$$
y_{t}=f\left(k_{t}\right)
$$

A hatékony létszám növekedése egyenlö a népesség növekedési ütemével $\left(\mathrm{g}_{\mathrm{N}}\right)$ és a technikai haladás által lehetővé tett termelékenységjavulással $\left(\mathrm{g}_{\mathrm{A}}\right)$. A tőke növekedése $\left(\mathrm{g}_{\mathrm{K}}\right)$ pedig megegyezik a megvalósított beruházásokkal, ami viszont szükségképpen egyenlő a megtakarításokkal.

$$
\left(d_{K} / d t\right) / K_{t}=I_{t} / K_{t}=S_{t} / K_{t}=s \cdot Y_{t} / K_{t}=s y_{t} / k_{t} \rightarrow g_{K}=s \cdot f(k) / k
$$

ahol $s=S / Y$.

A rendszer a potenciális kibocsátás $\left(Y_{p o t}\right)$ állapotában van egyensúlyban, ami stabil egyensúly (a neoklasszikus paradigma szerint). Ebben a kitüntetett helyzetben a kapacitások $(K, A L)$ teljesen kihasználtak, de ez csak egyetlen meghatározott $k^{*}(K / A L)$ érték mellett teljesül, amely az egyes tényezők termelékenységének a függvénye. Az egyensúlyi növekedés a potenciális kibocsátás mentén való növekedés, ami pedig úgy valósulhat meg, hogy az egyes tényezők $(K, A L)$ azonos ütemben nőnek, s így k állandó.

$$
d k / d t=0=s \cdot f(k)-\left(g_{N}+g_{A}\right) \cdot k
$$

A fenti egyenlet azonban kizárólag a már említett $k^{*}$ esetén $\left(Y_{p o t}\right)$ valósul meg:

$$
s \cdot f\left(k^{*}\right)=\left(g N^{+} g_{A}\right) \cdot k^{*}
$$

A $k^{*}$-gal jelzett egyensúlyi pont stabil, vagyis a modell felépítéséből adódóan, ha a nemzetgazdaságban a tőkearány ettől eltérő, akkor (a nemzetközi tőkemozgásoknak 
köszönhetően) automatikus alkalmazkodási mechanizmus révén visszatér a rendszer az egyensúlyba. Ebben a pontban a termelés, a tőke és a hatékony létszám növekedési üteme megegyezik, amit a hatékony létszám növekedése determinál.

A neoklasszikus modell szerint tehát az egyensúlyi növekedési ütem a potenciális kibocsátás növekedésével egyenlő, azaz csak egyensúlyban lévő rendszer produkálja - és ennek ütemét $g_{N}+g_{A}$ határozza meg, amihez $g_{K}$ idomul -, ha azonban nem a potenciális kibocsátás állapotában van a gazdaság, akkor a nem-egyensúlyi növekedés $\left(g_{K} \neq g_{N}+g_{A}\right)$ addig tart, amíg az egyensúly helyre nem áll.

A modell alapján az alábbi következtetéseket lehet levonni.

- Az állandó és kitüntetett (egyensúlyi) növekedési ütem mellett az egy főre eső jövedelem szintje függ $s$ és $g_{N}$ alakulásától.

- Az állandó ütemü (egyensúlyi) jövedelemnövekedés szintje függ a technikai haladástól, de független az $s$ és a $g_{N}$ alakulásától.

- Egyensúlyi növekedés mellett $K / Y$ változatlan, hiszen azonos ütemben nőnek, vagyis a tőke határterméke konstans.

- A növekedésben a gazdaságpolitikának nincs szerepe, csak a technikai haladásnak.

- Hosszú távon a gazdaság eléri az egyensúlyi növekedési ütemet, függetlenül a kiinduló állapottól.

- Az egyensúlyi növekedési pálya eléréséig jelentős konvergencia figyelhető meg (országon belül és országok között), hosszú távon pedig egymáshoz simulnak a nemzetgazdaságok növekedési pályái, ugyanis valamennyi gazdaságra ugyanaz az egyensúlyi pálya érvényes.

A neoklasszikus növekedési modellel kapcsolatban több probléma is felmerült. Az egzogén technikai haladás feltételezése roppant kényelmes, azonban elméleti szempontból nehezen elfogadható, és a gyakorlat sem igazolja. Továbbá a technikai haladás tényezőnövelő megjelenítési formájából semmiféle következtetést nem tudunk levonni a technikai haladás okaival és forrásaival kapcsolatban. A technikai haladás okai nyilvánvalóan magában a gazdaságban (annak szerkezetében, fejlettségi fokában stb.) rejlenek, azaz a technikai haladás 
ütemét a gazdaság endogén módon határozza meg. A technikai haladásnak tehát az időtől nem közvetlenül, hanem közvetve, azaz a termelési tényezők változásain keresztül kell függnie.

Másként megfogalmazva a modell nem veszi figyelembe a nem-megtestesült technikai haladást. A valósághoz sokkal közelebb áll a termelési függvény alábbi felírása:

$$
Y=A \cdot F(K, L,)
$$

ahol $A$ a nem-megtestesült technikai haladás (vagy teljes tényező hatékonyság, TFP-Total Factor Productivity). Belátható, hogy a kibocsátások relatív változása felbontható az alábbiak szerint:

$$
d Y / Y=d A / A+d K / K+d L / L
$$

Egyes empirikus vizsgálatok alapján $d A / A$ akár 70 százalékot is magyarázhat a növekedésböl, amit így a neoklasszikus növekedési modell figyelmen kívül hagy. Ez a tényező a gyakorlatban bármi lehet: jogrendszer, munkaszervezési újítások, jobb innovációs környezet, hatékonyabb vállalatirányítás, stb.

A modell szerint a nemzetgazdasági megtakarítás szintje nem hat a növekedésre. A múltbeli tényadatok azt sugallják, hogy ez a következtetés sem állja meg a helyét. A múlt század második felében a gyorsan növekvő ázsiai országokban a megtakarítások a GDP 35-40 százalék tették ki, Magyarországon 23-24 százalék, míg Latin-Amerikában 15-20 százalék volt ez az arány, ami szoros korrelációt mutat az egyes térségek növekedési dinamikájával.

A modell következtetéseként egy olyan növekedési pálya rajzolódik ki, amely minden nemzetgazdaságra nézve azonos, így azoknak konvergálniuk kell. A tapasztalatok szerint a jövedelemkülönbségek inkább nőttek, vagy nem csökkennek olyan mértékben, ahogyan az a modell alapján elvárható lenne, és a növekedési pálya függ a kiinduló szinttől.

A modell csak a jövedelmi szintekben meglévő csekély eltéréseket volt képes magyarázatot adni, de nem tudott magyarázattal szolgálni a kialakult jövedelemkülönbségekre, illetve nem tudta jól magyarázni a jövedelemkonvergenciát. 
Az úgynevezett AK modell a neoklasszikus növekedési modell speciális esetének tekinthető annyiban, hogy eltekint a munkaállomány explicit figyelembevételétől. A modell kiinduló feltevése az, hogy a termelési szerkezetet az úgynevezett $A K$ típusú termelési függvény írja le:

$$
Y(t)=F[K(t)]=A K(t) ; A>0,
$$

ahol $A$ egy konstans szinttényező.

Ez a modell tehát a termelési függvény konkrét specifikációját alkalmazza. A termelési függvény alakjára nem érvényes a tényezőnkénti csökkenő hozadék. A csökkenő hozadék hiánya irreális feltevésnek tünhet, ha azonban a $K$ a szélesebb értelemben vett tőkeállományt, azaz a fizikai és humántőkét jelenti, akkor a modell már jobban védhetővé válik. A termelési függvényt intenzív alakban felírva a következő kifejezést kapjuk:

$$
y(t)=f[k(t)]=A k(t)
$$

Ennek a függvényformának további sajátossága a standard neoklasszikus termelési függvénnyel szemben, hogy az $A$ konstans szinttényező miatt a tőkeintenzitás szerinti átlag-, és határterméke minden pozitív $k(t)$ értékre megegyezik:

Ha a fenti termelési függvényt a neoklasszikus modellben meghatározott tőkeakkumulációs összefüggés szerint alakítjuk át, akkor a modell alapegyenletére a következő adódik:

$$
\gamma_{k}=k^{\prime}(t)=k(t)=s f(k(t)) / k(t)-(n+\delta)=s A-(n+\delta) .
$$

A fenti képlet alapján láthatjuk, hogy a növekedési ütem minden $k(t)$ esetén konstans. A $\gamma_{k}$ pozitív, ha $s A>(n+\delta)$, negatív ha $s A<(n+\delta)$ és zérus, ha $s A=(n+\delta)$.

Mint az látszik, az AK modell két lényeges ponton különbözik a neoklasszikus modelltől. Egyrészt különbözik abban, hogy az $s f(k(t))=k(t)=s A$ kifejezés nem csökkenő függvénye 
$k(t)$-nek, hanem egy konstans. Így tehát a $\gamma_{k}$, az $s A$ és $n+\delta$ konstansok különbségeként adódik $k(t)$ minden értéke esetén, vagyis $k(t)$ állandó ütemben nő:

$$
\gamma_{k}^{*}=s A-(n+\delta)>0 .
$$

Mivel azonban $y(t)=A k(t)$, és $c(t)=(1-s) y(t)$, ezért $\gamma_{y}^{*}=\gamma_{c}^{*}=\gamma_{k}^{*}$ is teljesül, azaz az egy före jutó fogyasztás és kibocsátás is ugyanazzal a konstans ütemmel növekszik.

Másrészt eltér ez a modell a Solow-modelltől abban, hogy itt teljesül az az összefüggés, hogy minél magasabb a megtakarítási hányad $(s)$, annál nagyobb lesz a hosszú távú egy före jutó kibocsátás növekedési üteme. Hasonlóan, ha valamilyen oknál fogva a termelés szintjét kifejező $A$ nő, akkor a növekedési ütem is nő, továbbá, ha $n$ vagy $\delta$ csökken, akkor az szintén a növekedési ütem növekedését jelenti.

Tehát az AK modell esetén létezhet a kibocsátásnak pozitív hosszú távú növekedési üteme, amelyet - egzogén technikai haladás nélkül - maga a modell endogén módon határoz meg. A fentiekből kitünik, hogy az AK modell képes magyarázni endogén növekedési ütemet, ezért endogén növekedési modellnek tekinthető.

A fenti megközelítés alapján bontakoztak ki az endogén növekedéselméletek a múlt század utolsó felében. Ezek változtatnak azon a feltevésen, hogy a hosszú távú egyensúlyi növekedési pályának a meredekségét a technológiai haladás csak egzogén módon befolyásolja, azaz a technikai fejlődés külső adottság és minden nemzetgazdaság számára azonos. Feltételezésük szerint a technikai fejlődés is endogén változók (vagy országspecifikus tényezők) függvényeként jelenik meg.

Az endogén növekedési elméletek azzal a feltételezéssel élnek, hogy különböző tényezőknek pozitív externális hatásuk van a termelési tényezők hozadékára, amelyek növelik a tőke, vagy a munka hozadékát, termelékenységét, és így ezek fokozásával kínálati oldalról befolyásolható a növekedési pálya. 
A neoklasszikus modellben alkalmazott meg nem testesült technikai haladás csak akkor tekinthető a valóságot megfelelően leíró modellnek, ha feltételezzük, hogy az valamennyi termelési tényezőre állandóan és azonos mértékben hatással van. Mivel azonban a több tíz éve használatban levő gépek termelékenységét a müszaki fejlődés legújabb eredményei nem javítják, a technikai haladás kizárólag a legújabb gépekben ölt testet. Ezt nevezzük megtestesült technikai haladásnak. A megtestesült technikai haladás első modellje Solowtól [1960] származik. Solow szerint a régi gépek alacsonyabb termelékenységüek, mint az új gépek. Solow a tőkejavak életkorát használja fel a technikai haladás szintjének meghatározásához. Az ilyen típusú modelleket hívjuk évjáratmodelleknek.

Arrow [1962] kritizálja a munka időbeli homogenitásának feltevését. Szerinte, ha minden egyes évjáratban a gépek kapacitása azonos, akkor az egymást követö évjáratokban az egyes gépekhez szükséges munkamennyiség csökkenő tendenciát mutat. Arrow szerint ugyanis minden korábbi beruházással nyert tapasztalat („learning by doing”) hozzájárul a termelékenység szintjének javulásához.

Colinsk [1967] szerint a technikai haladás üteme függ az egy före jutó kibocsátástól. Egy gazdagabb országban több erőforrás vehető igénybe oktatásra, és kutatásra, amelyek végső soron meghatározzák a termelékenység alakulását. Colinsk eredménye abban is eltér a neoklasszikus modellektöl, hogy nála a megtakarítási ráta növelése a jövedelem növekedési ütemére is hatást gyakorol. Így az állam által előidézett megtakarítási ráta növekedése hatásos politikának bizonyul a gazdaság hosszú távú élénkítéséhez.

1. A megtakarítási ráta növelése növeli a garantált növekedés rátáját.

2. Az amortizációs kulcs (javítási költségek) növekedése csökkenti a garantált növekedési ütemet.

3. A kibocsátás növekedési ütemét nem egy egzogén, hanem egy endogén tényező határozza meg.

4. Az egy före jutó kibocsátás csökken, ha $n$; azaz a népesség növekedési üteme nő, hiszen $n$ növekedése csökkenti $k$ értékét, ezen keresztül $\gamma y$-t is. 
Colinsk empirikus vizsgálata (56 országra 1950-től 1963-ig) alátámasztotta, hogy a növekedési rátát pozitívan befolyásolja a megtakarítási ráta és negatívan a népesség növekedési rátájának növekedése. Vizsgálata továbbá igazolta, hogy $n$ növekedése csökkenti $\gamma y$ értékét.

Mankiw-Romer-Weil [1992] általánosították a Solow modellt a humántőke beépítésével a termelési függvénybe.

A modell a következő első fokon homogén termelési függvényből indul ki

$$
Y(t)=K^{\alpha}(t) H^{\beta}(t)[L(t)]^{1-\alpha-\beta},
$$

ahol $\alpha+\beta \leq \cdot 1$, és $H(t)$ az emberi (humán-) tőke nagysága. A termelési függvényt intenzív formában felírva kapjuk, hogy

$$
y(t)=k^{\alpha}(t) h^{\beta}(t)
$$

ahol $h(t)$ az egy före jutó humántőke állomány, azaz $h(t)=H(t) / L(t)$. Ezen kívül mind a fizikai, mind a humántőke bővülésére a neoklasszikus modell feltevései érvényesülnek:

$$
\begin{aligned}
& K^{\prime}(t)=s_{k} Y(t)-\delta K(t), \\
& H^{\prime}(t)=s_{h} Y(t)-\delta H(t) .
\end{aligned}
$$

Ekkor a gazdaság fejlődését a Solow-modell analógiája alapján a

$$
\begin{aligned}
& k^{\prime}(t)=s_{k} y(t)-(n+\delta) k(t) \\
& h^{\prime}(t)=s_{h} y(t)-(n+\delta) h(t)
\end{aligned}
$$

egyenletek írják le.

Az MRW modellnek létezik lokálisan aszimptotikusan stabil stacionárius megoldása. Az MRWmodell $\left(k^{*} ; h^{*}\right)$ stacionárius pontjában azonban, hasonlóan a Solow-modellhez, az egy före jutó kibocsátás nem növekszik: 


$$
\gamma_{y}=\alpha \gamma_{k}+\beta \gamma_{h}=0
$$

tehát az MRW modell sem képes magyarázni az egy főre jutó kibocsátás pozitív növekedési rátáját.

Ez a modell az endogén növekedéselméletek azon irányzatán alapul, amelyek a humántőke változásával próbálják magyarázni a gazdasági növekedést, pontosabban a modellben szereplö tőke fogalmát terjesztik ki a humántőkére is. Az ilyen típusú elméletekben a termelési folyamatban nemcsak a fizikai értelemben vett tőkeállomány és munkaerő vesz részt, hanem a szakképzettséget, szakmai tudást és jártasságot megtestesítő humántőke is. Minél nagyobb az egy fơre jutó tőkeállomány, annál nagyobb a gazdaság humántőke-igénye. E módosítás nélkül a hagyományos elméletek nem képesek magyarázni az országok között tapasztalható jövedelemkülönbségeket.

Erre a kutatási irányra, és általában is az endogén növekedés elméletekre az egyik legnagyobb befolyást Lucas [1988] tanulmánya gyakorolt. A megközelítés nem előzmény nélküli, újdonsága a modell szerkezetében rejlik. Tegyük fel, hogy a kibocsátást a következő egyenletek határozzák meg:

$$
Y_{t}=A k_{t}^{a}\left(h_{t}, \lambda\right)^{1-a}
$$

ahol $h_{t}=h_{t} \delta(l-\lambda)^{\delta}$, és $\delta>0$ technológiai paraméterek, $h_{t}$ pedig a humántőke állománya.

A döntési probléma a korábbiakhoz képest annyival vált bonyolultabbá, hogy most a rendelkezésre álló munkaóra optimális allokációjáról is kell dönteni. A teljes rendelkezésre álló idő $(l)$ részben termelésben hasznosítható $(\lambda)$, részben pedig humántőke felhalmozásra (tanulásra) fordítható $(l-\lambda)$. A második egyenlet rendkívül egyszerü, de tartalmazza a tudás megszerzésének, illetve növelésének egy fontos jellemzőjét: a humántőke-felhalmozás egy társadalmi tevékenység, amelyhez az emberek közötti kapcsolattartásra, a már megszerzett tudás másoknak való átadására van szükség. Ezért Lucas modellje szerint a humántőke bővülése a humántőkének múltban elért szintjétől függ. 
Ebben a modellben megmutatható, hogy az egyensúlyi reálkamatláb kizárólag az egzogén paraméterek függvénye. Ebben az értelemben eredményünk hasonló a korábban tárgyalt $A K$ modelléhez. Az alapvető különbség azonban az, hogy ennek a reálkamatlábnak megfelel egy optimális humántőke/fizikai tőke arány. Ha tehát valamilyen kezdeti állapotban $h_{t} / k_{t}$ eltér az egyensúlyi értéktől, akkor a gazdaság lassabb (gyorsabb) fizikai tőke, gyorsabb (lassabb) humántőke felhalmozása révén éri el az egyensúlyt.

A humántőkének a gazdasági növekedésben betöltött szerepét Lucas után számos kutató elemezte. Becker, Murphy és Tamura [1990] megmutatta, hogy a kevés humántőkével rendelkező gazdaságokban a társadalom tagjainak döntései nem vezetnek ennek a helyzetnek a megváltoztatásához, tehát a növekedés továbbra is alacsony marad. Azariadis és Drazen [1990] modelljében a humántőkének el kell érnie egy kritikus szintet ahhoz, hogy a gazdaság növekedhessen. A küszöbszint alatt a humántőke nem segíti a növekedést. A jövedelemegyenlőtlenségek és a növekedés kapcsolatának elemzéséhez is kiinduló pontot szolgáltat a humántőkének a társadalmon belüli megoszlása, amint azt Glomm és Ravikumar [1992] valamint Tamura [1991] elemzései megmutatták.

A humántőke megragadásának egyik módszere a minimálbér és az átlagbér összehasonlítása. Ekkor azzal az előfeltevéssel kell élni, hogy a minimálbéren foglalkoztatottak minimális szintű humántőkével rendelkeznek, és így a minimálbér és az átlagbér különbségéből kiszámítható a humántőke részesedése. Történtek kísérletek arra vonatkozóan is, hogyan lehetne az iskolai végzettség tőkeértékét meghatározni, és ezt a lakosság iskolai végzettség szerinti megoszlásának felhasználásával a nemzetgazdaság humántőke állományának meghatározásához felhasználni. Mindezek a módszerek a humántőke állományának meghatározására nem nevezhetőek egzaktnak, nagyfokú szubjektivitást visznek a modellekbe, ezért jelentőségük inkább elméleti.

Az endogén növekedési modellek másik típusa az innovációt, az új termékek és technológiák létrejöttét állította a vizsgálatok középpontjába. Ezek a munkák arra a megfigyelésre épültek, hogy a találmányok jellege hasonlatos a közjavakéhoz. Ez azt jelenti, hogy egyrészt egy találmányt egyszerre akár többen is használhatnak, másrészt a találmány tulajdonosa jogi eszközökkel sohasem zárhatja ki tökéletesen a találmány használatából azokat, akik ezért nem fizettek. Erre építve dolgozta ki Romer [1994] az első tökéletlen versenyre épülő dinamikus makroökonómiai modellt. A kutatás eredményeit nála a közbenső javakat előállító szektor 
hasznosítja, aminek következtében folyamatos horizontális termékdifferenciálódás megy végbe. A felhasználó szempontjainak mind jobban megfelelő termékek megjelenése az, amely növeli a gazdaság hatékonyságát. Mivel a találmány tulajdonosai egyedül képesek az új termék előállítására, ezért a gazdaságra a monopolista verseny a jellemző.

Az előző modellben az új termékek sohasem váltják fel a régieket, hanem azok egymás mellett élnek. Természetesen a régi, kevésbé használható termékek ára csökken, de sohasem tünnek el a gazdaságból. Alternatív megoldást javasolt Grossman és Helpman [1994]. Itt a gazdaságban rögzített számú áru van jelen. Az innováció ezeknek a termékeknek a minőségét javítja oly módon, hogy az új, vagyis a minőségileg jobb termékek kiszorítják a régebbieket. A jobb minőségü termékek pedig növelik a gazdaság hatékonyságát, és fenntartják a növekedést. Az innováció sajátos jellege miatt ezeket a gazdaságokat is monopolista verseny jellemzi.

A két eltérő megközelítés azonban hasonló következtetésekre vezet. A növekedés gyorsabb, ha a monopolista erőfölény nagyobb, ha több erőforrás áll rendelkezésre a kutatás folytatására és ha hatékonyabb a kutatás. Emiatt a szegény országok növekedése lassabb lesz, mint a gazdagabbaké.

A gazdasági növekedés alakulásában a beruházások és a megtakarítások alapvető szerepet játszanak. Ezért logikusnak tünik, hogy az a szektor, amely a megtakarítók és a beruházók között helyezkedik el, vagyis a pénzügyi szektor szintén fontos szerepet játszik a fejlödés alakulásában. A bankrendszer által a háztartások számára nyújtott likviditási szolgálatoknak a szerepét elemzi Bencivenga és Smith [1991]. Megmutatják, hogy ha a bankrendszer alacsonyan fejlett, akkor a háztartások vagyonuk túl nagy részét fogják likvid formában tartani, és ezért kevés forrás jut a beruházásokra. Levine [1992] ezt az elemzési keretet egészíti ki a bankrendszer tőkeallokációban játszott szerepének a vizsgálatával.

Az endogén növekedési modellek gazdaságpolitikai implikációi

Míg a neoklasszikus elméletnél a gazdaságpolitikának nem volt szerepe a növekedési ütem befolyásolásában (kivéve, hogy liberalizálja a nemzetközi áru-, tőke- és 
technológiaforgalmat), az endogén növekedéselméletek alapján már befolyásolható a technikai fejlődésen keresztül a hosszú távú növekedési ütem. Az endogén növekedéselméletek módosítottak a neoklasszikus növekedéselméletek végső konzekvenciáján, vagyis hogy az állam nem képes az ország hosszú távú növekedési pályáját befolyásolni. Az állam feladata itt az országspecifikus tényezők felismerése és kihasználása. Szerintük ugyanis az országspecifikus tényezők nem tünnek el a liberalizált nemzetközi tőkeáru- és technológiaforgalom keretein belül sem.

Az endogén növekedési elméletek magyarázatot kínálnak a nemzetgazdaságok növekedési ütemei közötti eltérésekre, és azt állítják, hogy a gazdaságpolitika képes befolyásolni a fejlödési pályát. Egyes modellek szerint ez a humántőke beruházások (vagyis oktatás és képzés) növelése révén valósítható meg, míg mások a technológiai beruházások externális hatásait hangsúlyozzák. Ez utóbbit nevezik „spillover” hatásnak, amikor egy technológiai újítás nem csak az adott iparágban fejti ki hatását, hanem tovagyürüzik a gazdaságban, és más szektorok is hasznot húznak belőle.

A magyar nemzetgazdaság hosszú távú modelljeinek kialakításakor az volt a legfontosabb célunk, hogy lehetővé váljon a gazdaság hosszú és középtávú folyamatainak vizsgálata. Erre szükség lehet egy felzárkózási pálya elemzésekor, de akkor is, ha olyan nagy ívü döntések hosszú távú hatásait szeretnénk számszerüsíteni, mint amilyen az EU csatlakozás vagy az euró magyarországi bevezetése.

Ilyen esetekben elengedhetetlen az endogén technikai fejlődés megjelenítése a modellben. Ez alatt azt értjük, hogy egy adott időszak gazdasági folyamatai befolyásolják a későbbi fejlődési lehetőségeket, konkrétan a termelési függvény paramétereit. Emellett természetesen a tőkeállomány nagysága is függ a korábbi időszakok beruházási döntéseitől. Így létrejön egyfajta visszacsatolás, a kapacitások szükössége a beruházási tevékenység fokozására ösztönöz, aminek hatására növekszik a kínálat, és helyreáll az egyensúly.

Miután áttekintettük a nemzetközi gyakorlatban alkalmazott növekedési modelleket, a következőkben bemutatjuk, hogy a különböző számszerüsített modellekben hogyan alkalmazták a fenti gazdaságelméleti premisszákat. 


\subsection{A holland modell ${ }^{28}$}

A modellt két holland közgazdász fejlesztette ki a 90-es években, de külön nevet nem adtak neki. A modell az endogén növekedéselméleten alapul, ami alkalmassá teszi hosszú távú prognózisok és elemzések készítésére, és így fogódzót adhat az általunk alkalmazott modell továbbfejlesztését illetően is.

A modellben a termelési blokk felépítése a következő. A technológia meghatározza a tőke termelékenységét, és az oktatás színvonalával együtt (amit itt az oktatásra fordított kiadásokkal mérnek) a rendelkezésre álló humántőkét. A tőke termelékenysége és a szükséges energiafelhasználás megadja a tőketényező kínálatát, a humántőke és a munkaerő-kínálat pedig megadja a rendelkezésre álló munkaerőt. Ezekből a tényezőkből áll elő a potenciális termelés (az az elméleti kibocsátás, amelyet maximális kapacitáskihasználás mellett elő lehetne állítani). Tehát ha minden faktor inputja (beleértve a munkaerőt is) adva lenne, akkor a jövedelem kínálati oldala endogén módon határozódna meg a blokkon belül.

Mivel azonban a termelés keresletorientált (ez az egyik alapfeltevés), egy pozitív beruházási sokk hatására például a munkaerő felhasználása csökkenni fog, a termelékenysége pedig nőni. A humántőke a modellben tehát, mint újabb termelési tényező jelenik meg a munkaerő helyettesítőjeként. Ekkor viszont már a termelés és a tőke adott szintje határozza meg a munkaerő iránti szükségletet, az ok-okozati sorrend tehát megfordult.

A termelési tényezők iránti kereslet meghatározói a következők:

- Termékár $=\mathrm{f}_{1}$ (múlt időszaki termékár, bér, termelékenység, adókulcs, energiaár, tőkeköltség, fejlesztési költségek)

- Beruházás $=\mathrm{f}_{2}$ (múlt időszaki beruházás, output, hosszú távú reálkamatláb, pénzkínálat, bér, energiaár, tőke hasznossága, fejlesztési költségek)

- Energia iránti kereslet $=\mathrm{f}_{3}$ (múlt időszaki energiakereslet, output, energia ára, bér, fejlesztési költségek)

- Hazai kutatás-fejlesztés $(\mathrm{K}+\mathrm{F})=\mathrm{f}_{4}$ (múlt időszaki $\mathrm{K}+\mathrm{F}$, output, $\mathrm{K}+\mathrm{F}$ költsége, bér, energia ára)

\footnotetext{
${ }^{28}$ Butter - Wollmer [1996] alapján
} 
- Müködőtőke import $=\mathrm{f}_{5}$ (világkereskedelem, hazai $\mathrm{K}+\mathrm{F}$ költsége, technológiai lemaradás, bér, energiaár, tőkeköltség)

A modellnek ez a része adja az időbeli dinamikát, amit kiegészít a keresleti oldal. A termelékenység alakulása befolyásolja az árakat és a béreket, a gazdasági növekedés befolyásolja a keresletet és így a végső áralakulást a piacokon.

A modell szerint munkapiacon, a béralku során nyílik lehetőség arra, hogy a termelékenységnövekedés pozitív hatásaiból a munkavállalók is részesedjenek. Az hogy a termelékenységnövekedés mekkora hányadát fordítják béremelésre, alapvetően a piac szegmentáltságától és a szereplők erőviszonyaitól függ, viszont alapvetően kihat a gazdasági növekedés fenntarthatóságára a jövedelemelosztáson keresztül. Ez mindenképpen indokolja ezen piac megfelelően részletes elemzését.

A holland modell érdekessége, hogy különbséget tesz a képzett („,fehérgalléros”, az új technológiát kezelni tudó) és képzetlen („,kékgalléros”) munkaerő között, a munkapiacot leíró egyenletekben.

Ez ma a magyar gazdaság modellezésénél az előbbiek alapján fontos szempont, hiszen itthon is egyre nagyobb gondot okoz, hogy a képzett munkások száma kevés, a képzetlenek számára pedig nincs elegendő munkahely, ami a munkanélküliségi szint csökkentését egyre nehezebbé teszi. Persze Magyarországon figyelembe kell venni a keleti és nyugati országrész közötti egyre fokozódó fejlettségi különbséget is, ami ezen a téren is aktív kormányzati szerepvállalást tesz szükségessé.

\subsection{A RAEM modell}

A RAEM modellt Elhorst és Oosterhaven [2006] fejlesztette ki, szintén Hollandiában, de már a 2000-es években. Egy SCGE (spatial computable general equilibrium) típusú általános egyensúlyi modellről van szó, mely közvetlenül képes figyelembe venni a régiók közti szállítást és munkaerő-áramlást. Közgazdasági alapját az új gazdaságföldrajz jelenti. A modellben a munkaerőpiac blokk egyaránt figyelembe veszi a migrációt és az ingázást is. A modell legújabb változatában (RAEM 3.0) ${ }^{29}$ továbbfejlesztésre került a modell struktúrája:

\footnotetext{
${ }^{29}$ Lásd: Ivanova, O. et al [2007]
} 
megtörtént a modell dinamizálása, megjelent a nemzetközi kereskedelem és a régiók közti migráció, a kormányzati szektor nagyobb szerepet kapott, és az utazások szerepét nagyobb részletezettséggel dolgozták ki. A modellnek ez a verziója negyven holland régió fogyasztását és termelését integrálja.

A modell a teljes népességet illetve a teljes ipari szektort egy-egy aggregált szereplőként kezeli, melyek döntéseit különböző optimalizációs kritériumok vezérlik (haszonmaximálás, költségminimalizálás). A következő gazdasági szereplöket különíti el a mikroökonómiai viselkedésük alapján: tizenöt termelő szektor, kormányzati szektor, külkereskedelmi szektor.

A RAEM egy rekurzív, dinamikus modell, melyben a tőkefelhalmozás és a technológiai haladás egyaránt dinamizálva jelenik meg, továbbá visszatekintő várakozás jellemzi. A modell rekurzív dinamikus struktúrája több ideiglenes egyensúly sorozatából áll. Az első egyensúly a sorozatban a 2006-os benchmark évre vonatkozik, majd minden egyes időperiódusban az egyensúly az adott időszakra feltételezett exogén feltételekből határozódik meg. Az egyensúlyi pontok a tőkefelhalmozáson keresztül kapcsolódnak egymáshoz, így a beruházási viselkedés meghatározása alapvető jelentőségű a modell dinamikus részének szempontjából.

A holland RAEM modell alkalmas arra is, hogy elörejelezze a gazdaságilag aktív népesség régión belüli és régiók közti eloszlását. Ez az „ingázó modell” képes arra, hogy szimulálja a magánkézben lévő és közösségi közlekedési hálózatok fejlesztésének hatásait. Segítségével a szerzőpáros hosszú távú (2020-ig terjedő) elörejelzést készített hat újonnan tervezett vasútvonal várható hatásaira. 


\subsection{A GMR modell}

A GMR-Magyarország ${ }^{30}$ (Geographic Macro and Regional Model) egy komplex makroregionális modellrendszer, mely alkalmas a fejlesztési politikák magyar gazdaságra gyakorolt regionális, ill. makroökonómiai hatásainak integrált elemzésére. Eredetileg az Új Magyarország Fejlesztési Terv hatáselemzésére dolgozták ki.

A modell legfőbb jellemzői: a kínálati oldal modellezése, a termelékenység és a technológia változásának közvetlen elemzése, a földrajzi hatások modellezése, valamint a makro- és regionális hatáselemzés. A modell húsz magyarországi régiót tartalmaz (19 megye és Budapest), továbbá négy szektort különít el: mezőgazdaság, ipar, szolgáltatások és közszolgáltatások. Közgazdasági alapját az endogén növekedéselmélet, az innováció földrajza, a regionális innovációs rendszerek és az új gazdaságföldrajz jelentik. A modell három egymáshoz kapcsolódó részmodellből áll: a TFP rész, mellyel a statikus agglomerációs technológiai hatásokat lehet elemezni; az SCGE almodell, mellyel a dinamikus agglomerációs technológiai, illetve a térbeli regionális hatásokat lehet vizsgálni; és végül a makroökonometriai részmodell, amely a fejlesztéspolitika makroökonómiai hatásainak elemzésére szolgál. A modell a regionális fejlesztéspolitikai lépéseket három csoportba sorolja: infrastruktúra-fejlesztés, humán erőforrás fejlesztése (oktatás illetve $\mathrm{K}+\mathrm{F}$ támogatása), produktív tevékenységek támogatása (elsősorban vállalkozások beruházásai). Ezek várható termelékenységi hatásait a TFP részmodell becsli meg, az így kapott értékek pedig az SCGE almodellbe csatornázódnak.

A GMR-EU modellt ${ }^{31}$ az euró-zóna 144 NUTS-2-es régiójára fejlesztettek ki, és az EU FP6 keretprogramjának - amely az európai kutatást és technológiai fejlesztést támogatja és finanszírozza - gazdaságpolitikai hatásvizsgálatára alkalmazzák. Ugyanazokat a részmodelleket tartalmazza, mint a magyar modell, és azok felépítése is hasonló a fentebb tárgyalt GMR-HU modellhez.

\footnotetext{
${ }^{30}$ Lásd: Varga A. [2007]

${ }^{31}$ Lásd: Varga A. [2011]
} 


\subsection{A Magyar Nemzeti Bankban használt modellek}

Benczúr, Simon és Várpalotai [2003] kalibrált hosszú távú makromodellel vizsgálta a fiskális politika és a gazdaság növekedési pályája közötti kapcsolatot. A modell egy hagyományos, klasszikus feltevéseken nyugvó ökonometriai modell. Ebböl adódóan viszonylag rugalmas, tág teret ad a fejlesztőknek arra, hogy az igényeiknek megfelelően alakítsák ki az egyenleteket. A kibocsátás egy Cobb-Douglas termelési függvény segítségével határozódik meg, melyben jelentős szerepet kap a TFP alakulása. Utóbbit két részre bontják, az egyik a belföldi folyamatok által meghatározott autonóm elem, még a másik a külföldi tőke externális hatásaitól függ.

A modell segítségével szerzők elsősorban arra keresték a választ, hogy a gyors felzárkózás időszakában - a 2000-es évek első felében - mennyi az esetleges eladósodás implicit költsége, vagyis az akkoriban lezajlott ,jóléti rendszerváltás” milyen valós hosszú távú társadalmi áldozatokkal jár. Ebből következően hangsúlyos elem a modellben a megtakarítások kezelése, ennek egyenlete - illetve ebből következően a fogyasztási egyenlet - mikroökonómiai megalapozottságú, intertemporális optimalizáción alapul.

A számítások azt mutatják, hogy a vizsgált időszakban a 20 százalékot is megközelítette a fogyasztás növelésének implicit kamatköltsége. Az akkoriban kibontakozó „fiskális alkoholizmus" tehát rendkívül nagy terheket rótt a későbbi évek adófizetőire, és sajnálatos módon épp az utóbbi években kialakult válságos időszakban volt kénytelen korrigálni korábbi lazaságát a hazai gazdaságpolitika.

Az elmúlt évtized második felében a makroökonómiai modellezésben előtérbe kerültek az egyensúlyi modellek, így az MNB is új modell kifejlesztésébe kezdett. A modell első változata 2004-re készült el, a végső változatot pedig Benk - Jakab - Kovács - Párkányi Reppa - Vadas [2006] publikálta. A modellt Negyedéves Előrejelző Modellnek (NEM) keresztelték, és mintegy fél évtizeden keresztül ezzel készültek az inflációs célkitüzéshez tartozó makrogazdasági előrejelzések, szcenárióelemzések.

A NEM modell egy módszertanilag meglehetősen kiforrott általános egyensúlyi modell, melyben a kínálatot egy CES termelési függvény határozza meg. A háztartások keresleti 
függvényében a rendelkezésre álló jövedelem a meghatározó, a kormányzati fogyasztás pedig természetesen egzogén. A GDP deflátor meghatározásakor egy továbbfejlesztett Phillips görbét alkalmaznak, míg a fogyasztói árakat legfontosabb komponensei segítségével becsülték. A monetáris politikát a Taylor-szabály vezérli. A modell a gazdaság valamennyi területén megbecsli a fontosabb folyamatokat, és kikényszeríti a főbb mérlegazonosságokat. Ez a fajta komplexitás segíti a megfelelést a makroökonometriai elvárásoknak, azonban bizonyos helyzetekben egyfajta rugalmatlanságot is okoz. Így például a NEM modell csak arra volt alkalmas, hogy egy adott kamatpályáról eldöntse, hogy annak mentén elérhető-e a jegybanki inflációs cél, de arra már nem volt képes, hogy nemleges válasz esetén alkalmas kamatpolitikát javasoljon.

Kezdetben a NEM modell meglehetősen jó előrejelző képességről tett tanúbizonyságot, azonban a 2008-ban kitört gazdasági-pénzügyi válság mélyülésével egyre pontatlanabbá vált. Időközben a modellt kidolgozó csapat is morzsolódni kezdett, egyik meghatározó tagja például az azóta megszüntetett Költségvetési Tanácsban folytatta pályafutását, ahol szintén egy negyedéves alapon müködő általános egyensúlyi modellel készültek a makroökonómiai elörejelzések.

Mindezen okok miatt a Magyar Nemzeti Bank munkatársai ismét hozzáláttak egy új modell kifejlesztéséhez, és e munka során előre deklarált célként fogalmazták meg, hogy a készülő modell egyfajta középutat jelentsen a merev, de módszertanilag megkérdőjelezhetetlen egyensúlyi modellek, és a néha kissé esetleges, de igen rugalmas, és így jó előrejelző képességű hagyományos ökonometriai modellek között. A munka gyümölcse a Monetáris Politikai Modell, ${ }^{32}$ amely egyszerre alkalmas előrejelzések készítésére és monetáris politikai döntéstámogatásra is.

A modellben endogén módon határozódik meg a kamat és árfolyam is. Szakítva az addigi gyakorlattal, a modell már egy teljes kamatpálya hatását képes elemezni, míg a korábbi modellek csak egyes kamatlépéseket értékeltek, feltételezve, hogy a vizsgált időhorizonton nincs további kamatváltozás. Ez az elemzési keret lényegesen növeli a döntéstámogató szakértők elemzési szabadságát.

\footnotetext{
${ }^{32}$ Lásd: Horváth - Köber - Szilágyi [2011]
} 
Az MPM negyedéves modell, és elsősorban a monetáris politika transzmissziós csatornáit kívánja megragadni. A modell kifejlesztői felismerték, hogy az ilyen csatornák között nem érdemes számolni a reálváltozók hosszú távú trendjeivel, mert azokra a monetáris politikai eszköztár csak korlátozottan képes hatni. Ezért a reálváltozókat (kibocsátás, fogyasztás, beruházás, export) magyarázó egyenletek bal oldalán a trendtől vett eltérések, azaz gapek szerepelnek. Az alapkamat kívánatos pályáját, azaz a monetáris politika reakciófüggvényét a Taylor-szabály alapján határozták meg, míg az árfolyam alakulását a fedezetlen kamatparitás determinálja.

A modell legfontosabb eleme a fogyasztói árindexet meghatározó blokk. Ebben az inflációt három részre bontották: indirekt adóktól tisztított maginflációra, indirekt adóktól tisztított, maginfláción felüli tételekre valamint az indirekt adók hatására. Ezek közül az első elem a legfontosabb, hiszen a jegybanki döntéseknek elsősorban erre van közvetlen hatása. Az adószürt maginfláció magyarázó változói között szerepelnek az árvárakozások, a fogyasztási kereslet, a reálbér, a reálárfolyam és végül az árindex másodikként említett része, a maginfláción felüli tételek adószürt adata. Utóbbi egyébként endogén módon határozódik meg a modellben (az egyenletben fontos szerepet játszanak a nemzetközi olajárak), míg az indirekt adók hatása egzogén.

Mindezekből látható, hogy az MPM annyiban egy leegyszerüsített modellnek tekinthető, hogy elsősorban a monetáris politika számára releváns változókra koncentrál, és nem kívánja „alulról építkezve” a gazdaság minden részterültét elemezni. Ugyanakkor a modell annyiban nagyon is komplex, hogy az előrejelzési időszakban lehetőség van egyfajta korrekcióra, azaz ennek során változhat például az árfolyam és kamat. Ez a rugalmasság tesz lehetővé, hogy a döntéshozók egy teljes kamatpálya elemzése megismerését követően határozzanak a nagy jelentőségű monetáris kérdésekről. 


\section{A hatásvizsgálathoz alkalmazott modell bemutatása}

\subsection{A modell motivációja}

A gazdasági rendszerváltást követően széles körben osztott vélekedés volt, miszerint Magyarország gyors fellendülésre számíthat, a nyugati struktúrákhoz való közeledés olyan energiákat szabadíthat fel, amelyek hatására szinte varázsütésre következik be a gyors konvergencia. Ekkoriban kezdődött meg egyfajta szakmai diskurzus a magyar gazdaság hosszú távú fejlődési lehetőségeivel kapcsolatban. A 90-es évek elején elmélyült transzformációs válság azonban gyorsan lehütötte a kedélyeket, és a téma még az előtt lekerült a napirendről, hogy érdemi módszertani vizsgálatok kezdődhettek volna. Rövid- és középtávú elörejelzések azonban már ekkor is készültek, a 90-es évek közepétöl több gazdaságelemző mühely is elöállt rendszeres elemzésekkel. Későbbi munkahelyemen ekkoriban fejlesztettek ki egy olyan negyedéves makromodellt, amellyel 1-2 éves időtávra készültek makrogazdasági elörejelzések.

A ezredforduló környékére a magyar gazdaság növekedése viszonylag magas szinten stabilizálódott, így újból felmerült a hosszabb távú gazdasági fejlődés elemzésének igénye, elötérbe került a lehetséges felzárkózási pályák vizsgálata. Ezt a „modellezési konjunktúrát” erősítette, hogy belátható közelségbe került Magyarország EU-tagsága, amitől további - a gazdasági konvergencia szempontjából - pozitív impulzusokra lehetett számítani. Mindezek a körülmények motiválták, hogy a 2000-es évek elején munkatársaimmal megkezdtük egy hosszú távú makromodell kifejlesztését. A legfontosabb célunk az volt, hogy a gazdaságpolitika számára tudjunk alkalmas kérdésekre megfelelő válaszokat adni. Ennek eszközeként a szcenárió-elemzést tartottuk a leghatásosabbnak, így a modellt is úgy alakítottuk ki, hogy ezen a területen legyen a legerősebb. Ezzel máris kizártuk az általános egyensúlyi modelleket, azok ugyanis nem elég rugalmasak ehhez, és nem is elsősorban pályák, hanem állapotok elemzésére alkalmasak. Ezért maradtunk a hagyományos ökonometriai modelleknél, ugyanakkor beemeltük a keretek közé az endogén növekedéselmélet adta lehetőségeket. Utóbbi egy hosszú folyamat eredménye volt, kezdetben 
nem is sikerült megfelelö egyenleteket találnunk ehhez, így csak a modell 2007-es verziójában történt meg a TFP endogenizálása.

A modell kifejlesztése előtt természetesen áttekintettük a vonatkozó nemzetközi szakirodalmat, ennek fontosabb elemeit a 2. és 3. fejezetben mutattam be. A készülő modellre a legnagyobb hatást a HERMIN modell gyakorolta, úgy véltük ez modellrendszer áll a legközelebb az általunk elképzelt struktúrához. Így a mi modellünk is kínálatorientált, úgy véltük ugyanis, hogy hosszú távon a kínálati oldal határozza meg a növekedési lehetőségeket. További hasonlóság, hogy a mindkét modell viszonylag kevés viselkedési egyenletet tartalmaz, ugyanakkor ennek többszöröse a mérlegösszefüggéseket megjelenítő összefüggés. Ugyanakkor teljesen eltérő szektorbontást alkalmaztunk, mint a HERMIN megalkotói. Ott egyrészt tradable - non-tradable bontással, másrészt pedig piaci - nem piaci megkülönböztetéssel dolgoznak. Ezzel szemben a mi modellünkben a nemzeti számlák rendszere a mérvadó, az abban szereplő kategóriáknak megfelelően beszélünk háztartási, vállalati és kormányzati szektorról, valamint külföldröl. A várakozásokat a HERMIN autoregresszív modellel kezeli, azaz lényegében az adaptív várakozások modelljét alkalmazza. Kezdetben mi is ehhez tartottuk magunkat, a későbbiekben fellépő torzítás miatt azonban áttértünk a racionális várakozásokra.

A modell kifejlesztésében már a kezdetektől részt vettem, és mindvégig én voltam az ECOTREND modell „felelőse”. Ez azt jelentette, hogy bár minden ilyen volumenű feladat megvalósítása alapvetően csoportmunkában zajlik, nálam futottak össze a szálak, én szintetizáltam a kollégáim részmunkáit. Természetesen a munkatársaim részvétele nélkül ez a modell így nem jöhetett volna létre. Miután a modell első verziójának kifejlesztése megtörtént, annak üzemeltetése döntően az én feladatommá vált. Ez azt jelentette, hogy a számos publikációban, tanulmányban, és konferencia-előadáson bemutatott számszerü eredményeket az esetek többségében én készítettem el. A modell 2007-es verziójának elkészítése már sokkal kevésbé volt team-munka, mint az első változat esetében, azonban kollégáimtól ekkor is sok segítséget kaptam. Az azóta végrehajtott változtatásokat már egyedül végeztem el. A modellt számos ponton átalakítottam, a legfontosabb újítás a 4.4 alfejezetben részletesen leírt visszacsatolások beépítése volt. 


\subsection{Kalibrálás versus becslés}

A modell paramétereit olyan módszerrel kapjuk meg, amely sztochasztikus egyenletekkel végzett becslések, múltbeli tapasztalatok, valamint szekértői becslések együttes felhasználásán alapul. Ezt az eljárást szokás kalibrálásnak nevezni, és ennek megfelelően nevezzük kalibrált modellnek az így kapott rendszert. ${ }^{33}$ A kalibrálással kapcsolatos elméleti megfontolásokról és gyakorlati problémákról add áttekintést az Európai Bizottság hivatalos honlapján található módszertani leírás. ${ }^{34}$

A módszer hátránya, hogy nem feltétlenül egzakt eljáráson alapul, hiszen becslöfüggvényeink csak paraméterértékek kiindulási alapját szolgáltatják. Ebből következően az így kapott modellek csak korlátozottan alkalmasak előrejelzésre, hiszen a becsült paraméterek eloszlása nem minden esetben ismert, és így például tesztelésük sem mindig lehetséges a hagyományos módszerekkel. Ugyanakkor az alkalmazott modell paramétereinek döntő többségét csak kismértékben vagy egyáltalán nem módosítottam a kalibrálás során, így ez az említett hátrány csak mérsékelten jelentkezik. Mindezek alapján fontosnak tartottam a modell elörejelzőképességének vizsgálatát, melynek részletes eredményeit az 5.1 alfejezet tartalmazza.

A kalibrálás előnye viszont az, hogy az így kapott modellek nagyfokú stabilitást mutatnak az egzogén változók alakulására nézve. Ez annak köszönhető, hogy az egzogén változók megváltozásakor nem becsüljük újra a modellt, hiszen az egyenletek paramétereinek értékét nem azok alapján határozzuk meg. Ennek pedig az ad jelentőséget, hogy szcenárióelemzéskor az összehasonlítani kívánt eseteket a modell szempontjából épp az különbözteti meg egymástól, hogy eltérnek az egzogén változók. Ráadásul mindez fokozottan érvényes abban az esetben, ha közepes, vagy hosszú időtávra készítünk szcenáriókat. Ilyenkor ugyanis a becsült modellek által az endogén változókra szolgáltatott becslések között akkora eltérések lehetnek, hogy az lehetetlenné teheti az összehasonlítást.

${ }^{33}$ Egy ökonometriai módszerekkel becsült modell esetében is szokás kalibrálásról beszélni abban az értelemben, hogy a modellező úgy próbálja megadni az egzogén paramétereket, hogy plauzibilis eredményeket kapjon. Dolgozatomban ennél tágabb értelemben használom a kalibrálás kifejezést, ami tehát magában foglalja a viselkedési egyenletek paraméterei változtatásának lehetőségét is.

${ }^{34}$ Lásd: European Commission [2009] 


\subsection{A modellépitésnél figyelembe vett tényezök}

Magyarországon még nem állnak rendelkezésre megfelelő hosszúságú idősorok a modellben szereplő összes egyenlet paramétereinek ökonometriai becslésére, ezért a szükséges paraméterek modellbe állításához bizonyos esetekben szakértői becslésre, illetve tapasztalatokra kell hagyatkozni, amiben a Magyarországéhoz hasonló gazdasági helyzetben lévő országok példája fogódzót adhat. Ennek megfelelően a paraméterek meghatározásakor az - EViews programcsomag felhasználásával megkapott - ökonometriai becsléseket csak kiindulási alapnak tekintettem, és szükség esetén egyéb külső információk alapján módosítottam azokat. Erre azonban - mint az előző alfejezetben utaltam rá - csak kevés esetben került sor, a modell egyenleteit bemutató 4.5 alfejezet részletesen ismerteti ezeket a beavatkozásokat.

Bár Magyarország kis nyitott gazdaság, így a gazdasági fejlődés kereteit nagymértékben meghatározzák a külső adottságok, mégis döntő szerepe lehet olyan belső folyamatoknak is, mint például a várakozások szerepe. Két ilyen területet említek most meg, mindkét jelenséggel részletesebben is foglalkozom majd a modell egyenleteit tartalmazó alfejezetben. Az egyik az inflációs várakozások hatása, amely olyan nagy befolyással van az inflációs ráta alakulására, hogy egyes szakértők szerint az ebből adódó inflációs perzisztencia lehet az egyik legföbb oka, annak, hogy a hazai infláció tartósan meghaladja a többi visegrádi ország hasonló mutatóját. ${ }^{35}$ A másik területet a külső konjunktúrával kapcsolatos vállalati várakozások alakulása jelenti, amely elsősorban a vállalati szektor beruházásait befolyásolja. Ebben az esetben ugyanis nemcsak az aktuális külső kereslet, hanem annak jövőbeli várható alakulása is fontos tényező, és az sem közömbös, hogy a döntéshozók mennyire reálisan érzékelik a tényleges folyamatokat.

Magyarország gazdaságának jövője összekapcsolódik az uniós tagságból adódó lehetőségekkel és kötelezettségekkel, ezért érdemes a jövőbeli perspektívákat ebben a keretben tárgyalni. Ez azért is fontos, mivel a magyar gazdaság modellezésénél hasznos lehet figyelembe venni a valaha hasonló gazdasági helyzetben levő kisebb európai országok tapasztalatait, ami egyrészt segítséget nyújthat a csatlakozás várható hatásainak modellezésében, másrészt pedig támogatást nyújthat a modell felépítésében.

\footnotetext{
${ }^{35}$ Lásd pl.: Bauer-Gábriel [2009]
} 
A magyar gazdaság fejlődésére ható legfontosabb közeljövőbeli tényezők a következők.

- Magyarország kis nyitott gazdasággal rendelkezik, a külső gazdasági kapcsolatok meghatározó jelentőségűek.

- 2004. május 1-től az Európai Unió teljes jogú tagjai vagyunk.

- A külföldi tőkebeáramlásnak, főleg a közvetlen tőkebefektetéseknek meghatározó a szerepük.

- A technológiai fejlődés nem lassul, egyes termékek életciklusa tovább rövidül.

- Figyelemmel kell lenni a munkanélküliség alakulására, és a munkapiac szegmentálódására.

- Számolni kell a Balassa-Samuelson (BS) hatással. ${ }^{36}$ A termelékenység hosszabb távon várhatóan gyorsabban növekszik az EU átlagánál, tehát nagy valószínüséggel jelentkezik a felzárkózó gazdaságokra jellemző BS hatás. Ilyenkor az egyensúlyban lévő gazdaságot folyamatos reálfelértékelődés jellemzi, miközben az egyensúlyi infláció meghaladja az utolérendő gazdaság átlagát, esetünkben uniós átlagot. Ez azt jelenti, hogy az egyensúlyi állapot változatlan árfolyammal is elérhető lenne, a tartósan magas infláció azonban ellentmond a maastrichti kritériumoknak. Ez hosszú távon restriktív gazdaságpolitikát tesz szükségessé, ami bizonyos mértékü növekedési áldozattal jár.

\section{A külkapcsolatok modellezése}

A hazai gazdaság külkapcsolatainak modellezésénél két szempont között szükséges a megfelelő súlyozás megtalálása. Egyfelöl a kis és nyitott hazai piac miatt a termelés erősen exportorientált, és az export a külső kereslet által meghatározott. Ez adja meg a potenciális hazai outputot, azaz a tényező-felhasználásokat, ami pedig az importigényt határozza meg. Másfelől viszont a beáramló tőke a hazai gazdaság relatív termelői árelőnyeit használja ki, és a multinacionális vállalatoknál meghozott termelési döntések alapján határozódik meg a hazai kibocsátás jelentős hányada, ami az export kínálatorientáltsága felé mutat.

Ennek az ellentétnek az a feloldása, hogy a tradable szektor termelése a multinacionális vállalatok nagy súlya miatt inkább a versenyképesség alakulása által meghatározott. Itt tehát a

\footnotetext{
${ }^{36}$ Lásd: Balassa [1964]
} 
belső kereslet illetve a fogyasztás nem meghatározó tényező, ami a gazdaságpolitika számára azt az üzenetet hordozza, hogy a klasszikus keresletélénkítő eszközökkel az ipari termelés csak mérsékelten és csak bizonyos szektorokban (pl. építőipar) növelhető. A non-tradable szektor termelése viszont a hazai kereslet által meghatározott.

A külkapcsolatok másik, alapvető jelentősége az árfolyam versenyképességre való hatásában jelentkezik.

Az árfolyamnak alapvetően kettős hatása van a versenyképességre.

- Költséghatás: leértékelődéskor megnő az import költsége, ezért a belföldi beszállítók versenyelőnybe kerülnek.

- Árhatás: leértékeléskor kevesebb devizáért kap az exportőr ugyanannyi forintot, tehát megváltozik a bel-, és külföldi jövedelmezőség, belföldön többet kérnek az árukért, ha a profitot növelni akarják.

Az ártípusú versenyképességet a szakirodalom a reálárfolyam alakulásával jellemzi. Az ilyen mutatók jellegzetessége, hogy csak pénzben mérhető kategóriákkal operál, nem veszi figyelembe az olyan nehezen számszerüsíthető tényezők hatását, mint az általános gazdasági környezet, az intézményi háttér vagy a munkaerő képzettsége. Természetesen ezek a tényezők is hatással vannak egy ország versenyképességére, de a reálárfolyam mutatói ezt nem képesek mérni.

Egy reálárfolyam-mutató lehet ${ }^{37}$ :

- ártípusú,

- költségtípusú,

- profittípusú.

a) Az ártípusú mutatókat leképezhetik

- termelői ár és

- fogyasztói ár alapon, illetve

- vegyes mutató is számítható.

${ }^{37}$ A tipológia alapját lásd pl.: Kovács [1999] 
A termelői áras reálárfolyam mutató:

$$
\mathrm{r}(\mathrm{ppi})=\mathrm{p}(\mathrm{ppi})-\mathrm{e}-\mathrm{p}(\mathrm{ppi})^{*},
$$

ahol p(ppi) a hazai termelői ár, p(ppi)* a külföldi termelői ár, és e az árfolyam (valamennyi jelölés logaritmizált változóra utal).

Ahhoz, hogy a mutatót megfelelően tudjuk értelmezni, a következő feltételezések szükségesek: a bel- és külföldi vállalatok csak az árban versenyeznek, a verseny tökéletes, nincsenek szállítási költségek, a termékek homogének. Ekkor, ha r(ppi) nő, az ország veszít a versenyképességéből. A versenyképesség általános feltétele, hogy $\mathrm{r}(\mathrm{ppi})<1$ teljesüljön.

Fogyasztói áras reálárfolyam mutató:

$$
\mathrm{r}(\mathrm{cpi})=\mathrm{p}(\mathrm{cpi})-\mathrm{e}-\mathrm{p}(\mathrm{cpi})^{*},
$$

ez a PPP mutató, ami a BS hatás miatt hazánk esetében általában csökken, vagyis fogyasztói ár alapon számolva Magyarország a felzárkózási folyamat során folyamatosan veszít versenyképességéből.

Vegyes mutató:

$$
\mathrm{r}(\mathrm{cpi} \text {-ppi })=\mathrm{r}(\mathrm{cpi})-\mathrm{r}(\mathrm{ppi})
$$

b) Bérköltség-típusú reálárfolyam mutató:

$$
\mathrm{r}(\mathrm{ULC})=\mathrm{w}-(\mathrm{y}-1)-\mathrm{e}-(\mathrm{w} *-(\mathrm{y} *-1)),
$$

ahol w az egy foglalkoztatottra jutó teljes bérköltség és y a termelékenység (egy foglalkoztatottra jutó GDP). Tehát w-(y-1) az egységnyi GDP-re eső bérköltség logaritmusa (Unit Labour Cost, ULC). A mutatóhoz használt feltételezések: tökéletes verseny és homogén termék, az árak kiegyenlítődnek, ebből következően versenyezni csak a költségekkel lehet, és csak a bérköltség csökkenthető.

c) Profit alapú reálárfolyam mutató:

$$
\mathrm{r}(\text { profit })=\mathrm{r}(\mathrm{ULC})-\mathrm{r}(\mathrm{ppi})=\left((\mathrm{w}-\mathrm{ppi})-\left(\mathrm{w}^{*}-\mathrm{ppi}{ }^{*}\right)\right)-\left((\mathrm{y}-1)-\left(\mathrm{y}^{*}-1\right)\right),
$$

ami a relatív termelői reálbér és a relatív termelékenység hányadosa.

A mutató másik értelmezése:

$$
\mathrm{r}(\text { profit })=((\mathrm{w}+1)-(\mathrm{ppi}+\mathrm{y}))-\left(\left(\mathrm{w}^{*}+1\right)-\left(\mathrm{ppi}^{*}+\mathrm{y}^{*}\right)\right),
$$

ami az egységnyi GDP-re jutó hazai és külföldi bérköltség hányadosa.

A mutató használata azon feltevés mellett indokolt, miszerint csak a munka a termelési tényező, bár a GDP-ben ez nem áll fenn. A képletben a nominális árfolyam nem szerepel, tehát a profit alapú reálárfolyam szerint a leértékelés nem befolyásolja a versenyképességet. 
A hagyományos modellek az importot a hazai végső kereslet és a relatív hazai és importárak alapján határozzák meg. Ennél jóval több adatot és lényegesen több számítást igényel, ha a kereslet minden elemét és ezek importtartalmát fogják össze egy input-output mátrixban. Mindkét megközelítés esetén az importárak a világpiaci árak és a devizaárfolyam függvényében alakulnak. Az export modellezése ennél sokkal komplexebb, mert itt figyelembe kell venni a hazai termelést, a külpiaci keresletet, valamint a hazai termelési költségek (egzogén) világpiaci árakhoz való viszonyát.

\section{Külföldi közvetlen tökebefektetés}

A külföldi áru- és tőkeáramlások modellezése a Magyarországhoz hasonló, erősen külpiac orientált, nyitott országok esetében megkerülhetetlen. A következőkben a tőkeáramlások jelentőségére térünk ki.

A rendszerváltó országokban, amelyek gazdaságai folyamatos tőkehiányban szenvednek, a külföldi tőke legfőbb szerepe abban áll, hogy segít áthidalni a hazai források szűkössége és a modernizáció erőforrásigénye közötti szakadékot. Másik lényeges, bár többek által vitatott szerepe pedig az, hogy a beáramló tőke főleg olyan ágazatokba települ, ahol az alacsony bérekre támaszkodva exportorientált termelést folytathat ${ }^{38}$. Így hatására az export növekedése felülmúlja a pótlólagos importnövekedést, ami javítja a felzárkózás miatt gyakran deficites folyó fizetési mérleget.

A közvetlen külföldi tőkebefektetéseket végrehajtó cégek arra törekednek, hogy a termékek termelését a lehető legkisebb tényezőköltséget eredményező helyre vigyék. Emellett a folyamatos tőkebeáramlást pedig az biztosítja, hogy a nemzetközi verseny folyamatos technológiai és termékmegújításra kényszeríti a multinacionális cégeket, akik az új

${ }^{38}$ Magyarországon a kizárólag bérelőnyökön alapuló tőkevonzás szerepe hosszabb távon nyilvánvalóan csökken, amit már a 2000-es évek elején jelzett néhány multinacionális cég csökkenő aktivitása (Mannesmann, IBM, Flextronics). Ugyanakkor a 2008-ban kitört válság hatására növekedett a magyar gazdaság relatív bérelőnye, így ez a jelenség hosszabb ideig maradhat fenn, mint arra korábban számítani lehetett. 
termékekhez szükséges know-how- $\mathrm{t}^{39}$, technológiát és szervezeti kultúrát eljuttatják a fogadó országba.

A 90-es években a rendszerváltásban élenjáró, viszonylag fejlettebb közép-európai országokban is az volt a jellemző tendencia, hogy a tőkeexportőrök a legújabb technológiát nem adták ki, elkerülendő, hogy az illetéktelen kezekbe kerüljön, csak a már „öreggé” vált technikát exportálták, amihez persze szükséges volt, hogy a fogadó országban meglegyenek a gyártáshoz szükséges feltételek. Mostanra azonban ez a fajta - elsősorban bérelőnyöket kihasználó - tőkeáramlás kifulladóban van, hiszen mára olcsóbb bérü országok is képesek megfelelő befektetési környezetet kínálni. Ebben a helyzetben Magyarország számára a fejlődés útja az újabb technikák átvételének ösztönzése, illetve a $K+F$ tevékenység megtelepedésének elősegítése lehet. Ez egyben meg is mutatja, hogy mi lehet a kormány szerepe egy ilyen megközelítésben. Az államnak eszerint biztosítania kell az új technológia fogadásához szükséges anyagi és humán infrastruktúrát, különös tekintettel a képzési rendszer megfelelő színvonalára. ${ }^{40}$

A beáramló tőke két csatornán keresztül fejti ki hatását, egyrészt a beruházások közvetlen befolyásolásán, másrészt a pénzügyi rendszeren keresztül. ${ }^{41}$

A külföldi közvetlen tökebefektetés ezen megközelítése egybecseng a szakirodalomban legújabban elterjedt endogén növekedési modellekkel is.

\section{Az EU és EMU csatlakozás hatásai}

Magyarország az EU csatlakozással arra is kötelezettséget vállalt, hogy belátható időn belül teljesíti a Gazdasági és Monetáris Unióba történő belépés feltételeit. Ha az ország az egységes valutaövezet tagjává válik, ezáltal megszünik az önálló monetáris- és árfolyam-politika

\footnotetext{
${ }^{39}$ Ez a modell feltevése szerint a külföldi közvetlen tőkebefektetést fogadó, relatíve elmaradott országban
} nincs meg.

${ }^{40}$ A külföldi közvetlen tőkebefektetés ezen modellezéséről jó összefoglalás található: J. Malley - T. Moutos: A Prototype Macroeconomic Model of Foreign Direct Investment

${ }^{41}$ S. Tsang - Y. Ma: Simulating the Impact of Foreign Capital in an Open Economy Macroeconomic Model of China 
lehetősége. Ezzel egyrészt a monetáris hatóság elveszíti az árfolyam és kamatpolitika feletti kontrollját, másrészt pedig megszünik a folyó fizetési mérleg eddigi, kiemelt szerepe az egyensúlyi mutatók között. Ez Magyarországon különösen hangsúlyos, hiszen külkereskedelmünk legnagyobb hányada már most is az EU piacaira irányul.

A valutaövezet tagjai számára az övezeten belüli integrált pénzügyi piac megkönnyíti a tagállamok közötti fizetési mérleg egyensúlytalanságok finanszírozását. Ez azonban nem jelenti azt, hogy monetáris unióban teljesen irrelevánssá válik egy tagállam fizetési mérlegének alakulása. Csak arról van szó, hogy az esetleges versenyképesség-romlás nem okoz fizetési mérleg válságot, hanem késleltetve, vállalati problémák formájában jelentkezik. A versenyképesség-romlás hatása makroszinten a kibocsátásban és a foglalkoztatottságban csak késve jelentkezik, akkor, amikor a versenyképtelen piaci szereplők tömegesen jelentenek csődöt vagy válnak hitelképtelenné.

\subsection{A modellben szereplő hatásmechanizmusok és visszacsatolások}

Az előző fejezetben már említettem, hogy a disszertációban alkalmazott számítások során használt modell a korábban kifejlesztett ECO-TREND modellen alapszik, azt is mondhatnánk, hogy annak egy jelentősen módosított változata. A legfontosabb változások a visszacsatolási mechanizmusok terén történtek, melyek a legfontosabb gazdaságpolitikai szabályokhoz kapcsolódnak. Bár a modell korábbi verzióiban is törekedtünk ezek alkalmazására illetve betartására a futtatások során, nem szerepeltek benne direkt visszacsatolások a hiánymutatók esetleges túlzott romlása esetére. Az általam alkalmazott modell ezzel szemben jelzi, amennyiben az államháztartási deficit meghaladja a 3 százalékos maastricht-i küszöböt, és azonnal javaslatot tesz a költségvetési kiadások automatikus csökkentésére. A modellezőnek ilyenkor lehetősége van arra is, hogy inkább módosítson valamelyik egzogén feltételen, remélve, hogy így helyreáll az egyensúly. A másik ilyen újonnan beépített fék a külső egyensúlyra vonatkozik, a külső finanszírozási igény esetében 6 százalékos limitet építettünk be. Meg kell jegyeznem ugyanakkor, hogy a magyar gazdaság jelenlegi helyzetében ez nem jelent effektív korlátot, az utóbbi néhány évben ugyanis többletbe fordult a folyó fizetési mérleg egyenlege, így a belföldi szektorok összessége nettó megtakarítóvá vált. 
A modellben a monetáris politika továbbra is egzogén maradt, ugyanis nem elsődleges célunk a kamatpolitika előrejelzése. Ráadásul utóbbit számos szubjektív elem is befolyásolja, melyeket értelemszerűen lehetetlen modellezni. Hasonló okokból nem vállalkoztunk az árfolyam endogenizálására, így az külsőleg adott a módosított modellben is. Ezzel szemben a fogyasztói árindex endogén módon határozódik meg, az ezt kifejező összefüggés a modell egyik fontos viselkedési egyenlete. Ezen a ponton egy újabb visszacsatolást építettem a modellbe. Eszerint amennyiben a modell által számszerüsített makrogazdasági pálya bármely pontján sérül a 3 százalékos inflációs cél, akkor a modell ezt jelzi a felhasználónak, aki ennek megfelelően módosíthatja az egzogén feltételeket, például magasabb kamatszintet állíthat be. Ezáltal az egyik legfontosabb gazdaságpolitikai szabály válik kikényszeríthetővé. Ugyanakkor arra is lehetőség van, hogy ezt a szabályt ne tartsuk be, sajnos a magyar gazdaságtörténet számos példával illusztrálja e lehetőség megtartásának jogosságát.

A modell egzogén változói részben a számunkra adottságként tekinthető világgazdasági környezet alakulását írják le, részben pedig gazdaságpolitikai eszközváltozók. A modell számos olyan paramétert is tartalmaz, amelyek a gazdasági ágensek viselkedését jellemzik. A külgazdasági környezetet jellemző változók alakulására szakértői becsléseket kell figyelembe venni, míg a gazdaságpolitikai eszközváltozók az adott forgatókönyvhöz tartozó fiskális és monetáris politikai elképzeléseket jelenítik meg. A paraméterek értékeit statisztikai idősorokon alapuló becslések, ill. múltbeli tapasztalatok és szakértői becslések alapján határozzuk meg. A modell endogén változóinak értékei az egzogén változók és a konkrét paraméterértékek függvényében alakulnak ki a dinamikus szimulációs futtatások során.

A modell adatbázisa a nemzetgazdasági számlarendszeren alapul. Az adatgyüjtés során elsősorban a KSH nyilvánosan elérhető adataira támaszkodtam, ugyanakkor bizonyos esetekben szükség volt további adatszolgáltatóktól származó kiegészítésekre. A fizetési mérleghez kapcsolódó adatok forrása a Magyar Nemzeti Bank, míg a részletes államháztartási adatok a Nemzetgazdasági Minisztériumtól származnak. A modell által inputként használt adatrendszer megtalálható a 3. számú mellékletben. A bemutatott táblázatban szerepel egyrészt a fontosabb változók neve, az általam alkalmazott jelölése, valamint az adatok konkrét értékei az elmúlt néhány évre vonatkozóan. A szigorúan a nemzeti számlákhoz 
köthető adatok jelölése megfelel a nemzetközi sztenderdnek, itt nem alkalmaztam saját jelöléseket, csak a megfelelő nemzetgazdasági szektorra utaltam értelemszerüen. ${ }^{42}$

A modell egyik további előnye, hogy a kalibrált paramétereket a felhasználó tetszése szerint változtathatja, így egyszerủen hajthat végre az igényeinek megfelelő szcenárió-elemzést. Ennek ára természetesen az, amit már a kalibrálással kapcsolatban általában is megemlítettem, hogy a módszer szubjektivitása miatt az egyes becslések pontatlanabbak lehetnek, mint a hagyományos ökonometriai módszerekkel kapott előrejelzések. Amennyiben viszont a modellező elsődleges célja nem a prognózisok elkészítése, hanem azok összehasonlítása egymással, az említett probléma nem jelentkezik, hiszen ilyenkor az egyes változatok közötti különbségek lesznek mérvadók számára. Ennek ellenére fontos, hogy a kalibrálás olyan értelemben is sikeres legyen, hogy viszonyítási alapként reális makrogazdasági pályát kapjunk, hiszen az alternatív változatok eltéréseit ehhez képest lehet értelmezni. A számítások elvégzése során épp ezért nagy hangsúlyt fektettem az alapváltozat precíz kidolgozására, és ebből a megfontolásból mutatom be meglehetős részletezettséggel ennek eredményeit az 5.2 alfejezetben.

A modell részben (ökonometriai módszerekkel számszerüsített) sztochasztikus, részben determinisztikus (mérleg-) egyenleteket tartalmaz. A modellben négy fó szektort különböztetünk meg: ezek a háztartási szektor, az államháztartási szektor, a vállalati szektor (amely a pénzügyi szektort is magában foglalja) és a külgazdasági szektor.

A GDP termelés oldalról egyenlő a gazdasági egységek által létrehozott hozzáadott érték és a termékadók összegével. A gazdasági modellekben mindig e termék- és szolgáltatástömeggel azonosítják a kibocsátást, hiszen ez az az árumennyiség, ami a gazdasági szektorok közötti cserében részt vesz, illetve a gazdasági szereplők végső fogyasztásra felhasználhatnak.

A GDP háromféleképpen írható fel, termelésként (lásd a modell kínálati oldalát), jövedelemként (lásd a jövedelemelosztást) és végső felhasználásként (lásd a modell keresleti oldalát), és ezek zárt gazdaságban ugyanazt az eredményt adják, hiszen ugyanazt a mennyiséget osztjuk fel különböző szempontok alapján. Ha viszont a modellben figyelembe

\footnotetext{
${ }^{42}$ Például B6 a rendelkezésre álló jövedelem nemzetközi jelölése, így B6HOUS a háztartások rendelkezésre
} álló jövedelme. 
vesszük a külföldet is, akkor a hazai végső felhasználás és a jövedelem többé már nem egyezik meg a hazai termeléssel. Nyitott gazdaságban ugyanis a hazai termelés a külfölddel szembeni termék és szolgáltatáscserével - ami a folyó fizetési mérlegben az áru és szolgáltatás soron jelenik meg - tér el a végső felhasználástól.

A kibocsátás másik oldalról nézve egyben a gazdaság összes jövedelmének is forrása, hiszen ez az az értékösszeg, amelyen a gazdasági alanyok osztozhatnak, és amely (pl. a pénzügyi szektor és az állam közvetítésével) a gazdaságban végső fogyasztásként megjelenik.

A GDP ezen felosztása, valamint a nominális és reálkategóriákból nyerhető információk eltérése magyarázatot is ad a modell blokkokra történő felosztására.

Az első blokk az összehasonlító áras GDP keresleti oldali meghatározására szolgál. Ezt követi az összehasonlító áras adatok folyó áras adatokká való alakítása. Ehhez szükségünk van egy ár-bér blokkra, amelyben indexeket határozunk meg a fogyasztási, a termelői, a beruházási, az export és az importárakra. Az ár-bér blokkhoz kapcsolódik a munkaerö-piac keresleti és kínálati viszonyait leíró blokk. A következő blokkban a fenti négy szektor közötti elsődleges jövedelemelosztást határozzuk meg. A jövedelem különböző tényezőkre bontható (munkabérek, tőkejövedelmek, termékadók ${ }^{43}$ ) és megoszlik a háztartások, a vállalati szféra, az állam (valamint a non-profit intézmények) és a külföld között. Ez a szektorbesorolás megegyezik az ESA '95 szektorbesorolásával, azzal az egyszerüsítéssel élve, hogy a pénzügyi és nem-pénzügyi vállalatokat nem kezeli külön. Ezután a jövedelmek újraelosztását jellemző paraméterértékeknek megfelelő rendelkezésre álló jövedelmeket számítjuk. A természetbeni juttatások és a fogyasztás meghatározása után kapjuk a szektorok bruttó megtakarításait.

Végül a tőketranszferek és az állóeszköz felhalmozás alapján adódik a szektorok nettó finanszírozási igénye. Az így kapott jövedelemelosztási mérleg kategóriái megfelelnek az ESA '95 rendszerben használatos fogalmaknak.

A modell blokkjai outputként a vizsgált makrováltozók éves előrejelzéseit adják, amelyek a nemzeti számlarendszer kategóriáihoz illeszkednek és így EU-konform mérési módszertan alapján adnak eredményeket a reál és a nominális változók várható alakulására.

\footnotetext{
${ }^{43}$ Ezeket nevezi az irodalom elsődleges jövedelemnek
} 


\subsection{A modell egyenletei ${ }^{44}$}

\section{Keresleti oldal}

A GDP keresleti oldala fogyasztásra, bruttó felhalmozásra és exportra osztható. Modellezési szempontból a fogyasztás esetén a vásárolt fogyasztás a meghatározó. A vásárolt fogyasztás magyarázó változója a rendelkezésre álló jövedelem, mivel az empirikus kutatások szerint a régió országainak többségében, köztük Magyarországon is, a háztartások jelentős hányada likviditáskorláttal küszködik. Ennek okai között többek között a pénzügyi rendszer fejletlenségét, a rendelkezésre álló jövedelem alacsony szintjét és az infláció miatti magas kamatokat szokták megemlíteni. Magyarországon a háztartások likviditáskorlátja ugyan jelentősen mérséklődött, a bankszektor az utóbbi években dinamikusan növelte lakossági portfolióját, de a lakossági szektor hitellehetőségei még mindig jelentősen elmaradnak a fejlett EU országokban tapasztaltaktól (pl. a hitelkártyák, folyószámlahitelek marginális szerepe miatt). A vásárolt fogyasztás egyenlete:

\section{LOG(QCPUR $)=0,025+0,6866 *$ LOG(B6HOUS(-1)/CPI(-1)) -0,4457*DEPORATE(-}

\section{1)/CPI(-1)*CPI(-2),}

ahol QCPUR a vásárolt fogyasztás változatlan áron,

B6HOUS a rendelkezésre álló jövedelem folyóáron, amit a fogyasztói árindex (CPI) segítségével alakítunk változatlan árassá,

DEPORATE a nominális betéti kamat, amit szintén a fogyasztói árindex segítségével alakítunk reálkamattá,

CPI a fogyasztói árindex, bázisindex formában (2000. évi árszint =1).

Az egyenlet paraméterei az eredeti ökonometriai becslésből származnak, csak a konstanson változtattam kismértékben, a pénzügyi válságot követő időszakban ugyanis tartósnak tűnik a háztartások pénzügyi fegyelmének javulása. Ez ceteris paribus alacsonyabb szintü vásárolt fogyasztást implikál, ezért a legfrissebb futtatásokban kisebb konstans szerepel. Az idősorok 
stacionaritása a kevés megfigyelés miatt csak korlátozottan tesztelhető, az eredményeket fenntartással kell fogadni. A szokásos teszteket azért lefuttattam, és azok nem utaltak egységgyök folyamatra, ezért nem képeztem differenciákat. Ez elméletileg sem tűnt indokoltnak, ugyanis a változatlan áras idősorok sok esetben valóban stacionerek, csak folyóáras adatok esetében bevett módszer a szinte automatikus differenciázás. A logaritmikus transzformációt a két érintett idősorban tapasztalható enyhe heteroszkedaszticitás indokolja, ráadásul így a becsült egyenlet illeszkedése is javult. A késleltetéseket elméleti megfontolásból alkalmaztam, tekintettel arra, hogy a lakosság fogyasztási döntési nem azonnal reagálnak a változó feltételekre. Ugyanakkor ez a specifikáció javította az egyenlet magyarázó erejét is.

A magánfogyasztás további elemei az önfogyasztás és a természetbeni társadalmi juttatások, melyekre nem becsültünk sztochasztikus egyenletet. Előbbiről azt tételezzük fel, hogy a vásárolt fogyasztással azonos ütemben nő, utóbbi értéke pedig a jövedelem-elszámolási blokkból adódik, hiszen ezt a tételt teljes egészében az állam juttatja a háztartásoknak. A közösségi fogyasztás egzogén változó, hiszen ennek mértéke politikai döntés kérdése. Az összes végső fogyasztás a magánfogyasztás és a közösségi fogyasztás összegeként adódik.

A bruttó felhalmozás állóeszköz-felhalmozásból és készletfelhalmozásból tevődik össze. Az állóeszköz-felhalmozás részei a vállalkozások beruházása, a költségvetési és társadalombiztosítási szervezetek felhalmozása és a háztartások beruházása (ez utóbbi jellemzően lakásberuházásokat jelent). A felhalmozások alakulását ökonometriai eszközökkel Magyarországon nem egyszerü modellezni, mivel megfelelő idősor csak 1995 óta áll rendelkezésre, és az ugyanebben az évben végrehajtott stabilizációt követő időszak adataiban figyelembe kell venni a jövedelemelosztásban bekövetkezett struktúraváltás hatásait. 1995-re ugyanis az államháztartási hiány olyan mértéket öltött, amire a lakossági megtakarítások már nem nyújtottak fedezetet. Ezzel létrejött az elméleti irodalomból jól ismert kiszorítási hatás. A gazdaság szerkezetében bekövetkezett torzulások vezettek 1995-ben a stabilizációs intézkedésekhez, amelyek fő célja a belföldi fogyasztás visszafogása és a jövedelmek vállalati szférába való átcsoportosítása - elsősorban a munkajövedelmek visszafogása, a társasági adó csökkentése útján -, valamint az állami kiadások lefaragása volt.

${ }^{44} \mathrm{Az}$ alfejezetben csak a legfontosabb egyenleteket mutatjuk be részletesen. A modell valamennyi egyenlete megtalálható az 1. sz. mellékletben. A modell paraméterrendszerét a 2. melléklet tartalmazza. 
Ezzel egyrészt javult az állam hitelpozíciója, másrészt a jövedelmek átcsoportosítása az üzleti szférába - a vállalatok nagyobb megtakarítási hajlandósága miatt - növelte a megtakarítási rátát. Mindkét tényező a külső finanszírozási igény csökkenésének irányába hatott. A külső finanszírozást elsősorban a privatizációs bevételek, az ország javuló nemzetközi megítélése nyomán meginduló müködőtőke-beáramlás biztosította, ami lehetővé tette az ország nettó külső adósságállományának csökkentését. Így a struktúraváltás következtében a beruházások szerkezete 1995-től folyamatosan átalakult, aminek következtében a paraméterek becslése komoly nehézséget okoz.

A vállalati szféra beruházásait a fentieknek megfelelően a következő egyenlettel modelleztük:

$\mathrm{dLOG}(\mathrm{QINVBU})=0,0567+0,5052 *$ LOANRATE/PPIFT*PPIFT(-1) -

$0,6332 * \mathrm{dLOG}(\mathrm{D} 1 \mathrm{DOM} / \mathrm{ERATEEU} / \mathrm{L})+0,2072 * \mathrm{dLOG}(\mathrm{BOOM}(1))$

ahol QINVBU a vállalati szféra beruházása változatlan áron,

LOANRATE a vállalati szféra hitelkamata, amit a termelöi árindex (PPIFT) segítségével alakítunk reálkamattá,

D1DOM a teljes hazai bértömeg (folyóáron, forintban), amiből forint/euró árfolyam (ERATEEU), valamint az alkalmazotti létszám (L) segítségével alakítunk ki egy nemzetközi összehasonlításra is alkalmas versenyképesség-mutatót,

BOOM a hazai export iránti külföldi kereslet mérőszáma.

Eszerint a vállalkozások felhalmozása függ a reálkamatok alakulásától, a béralapon számított versenyképességtől, valamint a külső kereslettől (ez a legfontosabb kereskedelmi partnereink importkeresletéből adódik). A versenyképesség negatív paramétere nem meglepő, az általam konstruált változó ugyanis fordított állású mutató, azaz a kisebb értéke utal a javuló versenyképességre. Az eredetileg becsült paramétereken a kalibrálás során nem változtattam érdemben, csak a konstans emeltem meg valamelyest. Erre azért volt szükség, mivel az utóbbi időszakban a pénzügyi válság hatására a vállalati beruházások nagyon alacsony szintre estek vissza, úgy éreztem reálisabb valamivel magasabb növekedési ütemmel kalkulálni. Ugyanakkor a paraméterek természetesen időben nem változnak, tehát a jövőre vonatkozóan - a hagyományos ökonometriai modellekhez hasonlóan - változatlan hatásmechanizmust 
feltételeztem. ${ }^{45}$ A dLOG transzformációt az érintett változók stacionaritásának hiánya indokolta, bár az idősorok rövidsége gyengíti a próbák erejét, ezekben az esetekben egyértelmünek tűnt az egységgyökök jelenléte. A differenciázást az idősorok heteroszkedaszticitása miatt kellett logaritmizálással is kiegészíteni. Kivételt képezett ez alól a reálkamat, amely transzformáció nélkül is stacionernek bizonyult. A késleltetési struktúrát az előre- és hátratekintő keresztkorrelációk alapján határoztam meg. A reálkamat késleltetett hatása nem meglepő, az viszont már inkább, hogy a versenyképesség esetében az egyidejü hatás bizonyult a legerősebbnek. A külső kereslet esetében alkalmazott „negatív” késleltetés magyarázata az lehet, hogy valójában a vállalatok várakozásai jelennek meg az egyenletben. Vélhetően azért bizonyult hatásos magyarázó változónak a jövőbeli konjunktúra, mert a vállalkozások beruházási döntéseit alapvetően határozza meg az, hogy milyen keresleti viszonyokra számítanak, és a jelek szerint ezek az - egy évre előretekintő - várakozások a múltban nem tértek el jelentősen a ténylegesen megvalósult konjunkturális helyzettől.

A bruttó felhalmozás további elemei (közösségi beruházások, háztartások beruházásai és a készletfelhalmozás) egzogén változók a modellben.

A keresleti oldal utolsó eleme az export, melynek egyenlete a következö:

$\mathrm{dLOG}(\mathrm{QX})=0,0481+1,9343 * \mathrm{dLOG}(\mathrm{BOOM})+0,0539 * \mathrm{LOG}(\mathrm{DIHEU})+$ 0,4305*dLOG(ERATEEU/D1DOM*L),

ahol QX a változatlan áras export,

DIHEU a közvetlen müködőtőke-beáramlás euróban.

Bár a szokásos tesztek az idősorok rövidsége miatt ezúttal is csak jelentős bizonytalanság emellett voltak elfogadhatóak, végrehajtottam a szükséges transzformációkat, melyek az eredmények alapján biztosították a stacionaritást. Eszerint csak tőkebeáramlás idősora nem tartalmazott egységgyököt, a logaritmikus transzformációra azonban itt is szükség volt az enyhe heteroszkedaszticitás miatt.

\footnotetext{
${ }^{45}$ Ez természetesen valamennyi viselkedési egyenletre érvényes.
} 
Az export alakulása elsősorban a keresleti viszonyoktól, valamint a versenyképesség alakulásától függ. Utóbbit ugyanúgy mérjük, mint a vállalati szféra beruházásainak egyenletében, a különbség csak annyi, hogy ebben az egyenletben az ottani mutató reciproka szerepel magyarázó változóként. Érdemes megemlíteni, hogy a külső kereslet meglehetősen magas paramétere egyáltalán nem mond ellent a válságot megelőző évek tapasztalatainak. Akkoriban ugyanis valóban az volt a jellemzö, hogy a magyar export növekedési üteme akár két-háromszorosan is meghaladta a föbb kereskedelmi partnereink keresletnövekedésének ütemét. A közvetlen müködőtőke-beáramlás szerepeltetése a korábban említett struktúraváltással függ össze, a külföldi töke ugyanis igen gyakran fektet be nagy exporthányadú ágazatokba. A modell korábbi változatában az árfolyam közvetlenül a magyarázó változók között szerepelt, azonban az eredményváltozóra gyakorolt hatása az újabb becslések során egyre gyengébbnek bizonyult.

Mivel a fenti egyenletben mindhárom paraméter pozitív előjelü, bizonyos gazdasági események hatása ellentmondásos lehet az export szempontjából. Például az Európai Unióhoz történt csatlakozás, valamint azt követően magyar gazdaság fokozatos integrációja az egységesülő európai gazdasághoz egyszerre hat pozitívan és negatívan is az exportlehetőségeinkre. Amennyiben a csatlakozást követő években valóban növekszik a külső kereslet (mert megszűnnek a még meglévő kereskedelmi akadályok), és bővül a külföldi tőkebeáramlás, akkor ez segíti az export fellendülését. Azonban amennyiben a magyar gazdaság nominálisan is elkezd felzárkózni a fejlettebb országokhoz - azaz növekszik a hazai ár- és bérszínvonal, - ez visszafoghatja a magyar export dinamikáját, s ezzel fékezheti a GDPnövekedés lehetséges ütemét is.

Árak

Magyarországon a gazdaság nyitottsága miatt az árakra a várakozások és a termelési költségek mellett, jelentős hatást gyakorolnak a világpiaci árak is, amelyek az árfolyamon keresztül fejtik ki hatásukat.

A blokkban egzogén változók a hazai kamatszint, a külső árak (pl. olajár), valamint a gazdasági szereplők árvárakozásai. 
A fogyasztói árindex alakulása az egzogén inflációs várakozásoktól, a termelői árak mértékétöl, az importált inflációtól és a nominális bértömeg (mint a fogyasztási kereslet meghatározó összetevője) alakulásától függ. Az importált infláció két tényezője a külső árszint (egzogén) és az árfolyam. A fogyasztói árindex egyenlete:

$\mathrm{dLOG}(\mathrm{CPI})=-0,0083+0,877 * \mathrm{dLOG}(\mathrm{CPIEXPECT})+0,14 * \mathrm{dLOG}(\mathrm{PPIFT})+$ 0,1708*dLOG(EARNINGDOM) + 0,0551*dLOG(PIMP),

ahol CPI a fogyasztói árindex,

CPIEXPECT a várt fogyasztói árindex,

PPIFT a termelői árindex forintban,

EARNINGDOM a keresettömeg,

PIMP az import árindexe (importált infláció).

Az egyenletben valamennyi változó egységgyök-folyamatnak bizonyult, ami nem meglepő, hiszen pénzben mért idősorokról van szó, és ezek esetében pedig ritka jelenség, hogy azok szintje stacionernek bizonyuljon. Így az összes változó dLOG transzformáltját szerepeltettem, ami azt jelenti, hogy a paraméterek rugalmasságként értelmezhetők. A gyakorlatban számos modellt használnak a fogyasztói árindex alakulására, így meglehetősen széles körből meríthettem a potenciális magyarázó változókat. Azonban azt is figyelembe kellett venni, hogy az inflációs modellek többsége csak erre az egy változóra fókuszál, míg az általam használt modell teljes makrogazdasági pályát határoz meg. Ezért az egyszerüségre törekedtem, elvetettem például, hogy külön modellezzem bizonyos termékcsoportok áralakulását. Így alakult ki a fenti egyenlet, amely azért tartalmazza a leggyakoribb magyarázó változókat. A keresztkorrelációk vizsgálata alapján az egyidejü kapcsolatok alkalmazása tünt a legmegfelelőbbnek, aminek az lehet a magyarázata, hogy egy éves modellben az egy időszaki késleletetés már túl nagy lett volna egy inflációs egyenletben, ilyen esetekben inkább néhány hónap a jellemző reakcióidő.

Külön említést érdemel az inflációs várakozások kezelése, ami a mindenkori monetáris politika egyik kiemelten kezelt mutatója. A probléma az, hogy a jelenség eleve nehezen mérhető, és így a modellezése is csapdákat rejt. A modell korábbi változatában például adaptív várakozásokat alkalmaztam, tekintettel annak elméleti megalapozottságára, valamint könnyü gyakorlati alkalmazhatóságára. A gyakorlati alkalmazások során azonban azt 
tapasztaltam, hogy ez tartós torzítást eredményezett, az elmélettel szemben megfogalmazott kritika a gyakorlatban is megállta a helyét. Ezért áttértem a racionális várakozásokra, ez szerepel az egyenlet jelenlegi változatában.

Az egyenlethez kapcsolódik egy fontos gazdaságpolitikai szabály is: amennyiben a fogyasztói árindex elörejelzett növekedése meghaladja a 3 százalékos inflációs célt, akkor a modellt kezelő szoftver ezt jelzi, és várja a modellező által javasolt intézkedést. Bár logikusnak tünhetne, hogy ilyen esetben automatikus válaszként emeljük az alapkamatot, azonban épp a közelmúltbeli események jelzik a legplasztikusabban, hogy ez nem lenne feltétlenül helyes megoldás.

A kamatszint egzogenitását több tényező is indokolja. Egyrészt az empirikus kutatások alapján nehéz kimutatni Magyarországon hosszútávú összefüggést a nominális kamatszint és a reálváltozók között, mivel a kamattranszmisszió mechanizmusát még mindig számtalan tényező korlátozza. Másrészt az 1995-2001 közötti csúszó leértékeléses árfolyamrendszerben a jegybanki kamatpolitika szerepe marginális volt, hiszen az árfolyamhorgony egyben ki is jelölte a szükséges kamatszintet. A 2001 októbere óta követett inflációs célkitűzés rendszerében a kamatpolitika szerepe huzamosabb ideig abban merült ki, hogy a jegybank a dollár és euró kamataihoz képest nagy kamatprémiummal igyekezett biztosítani a forint iránti jelentős keresletet, és így az erős forintárfolyamot. Ez egyben azt is jelentette, hogy a nominális kamatszintnek a reálváltozókkal való kapcsolata jelenetéktelen volt, annak mértékét elsősorban a fogyasztói infláció, illetve az árfolyam szintje határozza meg. ${ }^{46}$

A kamatok a modellben hatással vannak az államháztartás egyenlegére a kamatfizetéseken keresztül, az árfolyam szintjére (az eurózóna kamatszintjével együtt) valamint a felhalmozás alakulására. Az államháztartás helyzetének és a felhalmozás szintjének befolyásolásán keresztül így a jövedelem-újraelosztás alakulásában játsszák a fő szerepet. Az erősebb hazai valuta természetesen alacsonyabb hazai árakkal jár együtt, így a kamatszint áttételesen ugyan, de a fogyasztói árindexet is befolyásolja.

${ }^{46}$ További érv a kamatszint egzogén változóként kezelése mellett, hogy az irányadó kamat meghatározása az MNB Monetáris Tanácsának szerepköre. Mivel a Tanács döntéseit számos szubjektív elem is befolyásolja, továbbá a döntéshozók által figyelt tényezők egy része nehezen számszerűsíthető (pl. pénzügyi stabilitás, külföldi befektetők bizalma a magyar gazdaságban, a gazdaságpolitika hitelessége), elvetettem a változó esetleges endogenizálásának lehetőségét. 
Modellünkben a termelői árakat három tényező befolyásolja: a termelékenység, amit az egy alkalmazottra jutó GDP-vel mérünk, a keresetek alakulása, valamint az importárak (importált infláció). Tekintettel arra, hogy a közgazdasági elmélet alapján és a tapasztalatok szerint is a felsorolt változók változási üteme stacionárius, mind a négy változó logaritmusának változását szerepeltetjük a termelői árakat magyarázó sztochasztikus egyenletben:

$\mathrm{dLOG}($ PPIFT $)=-0,0217+0,0334 * \mathrm{dLOG}(\operatorname{PRODL}(-1))+0,3602 * \mathrm{dLOG}(\mathrm{W})+$ $+0,8036 * \mathrm{dLOG}(\mathrm{PIMP})$,

ahol PRODL a termelékenység,

$\mathrm{W}$ a (nominális) átlagkereset.

A magyarázó változók körül csak a termelékenység esetében bizonyult indokoltnak az elsőrendü késleltetés alkalmazása, a többi esetben az egyidejü korrelációk voltak a legerősebbek. Az egyenlet paraméterei a rövid idősoron elvégzett becslésből származnak, a kalibrálás során nem változtattam egyik értéken sem. Látható, hogy a termelő árak alakulásában az importárak szerepe meghatározó, a külső árszint 1 százalékos emelkedése 0,8 százalékos azonnali növekedést okoz a termelő árakban.

\section{Munkapiac}

A munkaerőpiac vizsgálatánál először a munkatermelékenységet határoztuk meg a hozzáadott érték és a foglalkoztatottak számának relatív alakulásával. A termelékenység egyrészt a termelési függvényben, másrészt a bértárgyalásokon játszik fontos szerepet.

A modellben közvetlenül a nominális átlagkeresetek (egységnyi munkaerőköltség) alakulását magyaráztuk az inflációs várakozásokkal, a termelékenység alakulásával és a munkanélküliség mértékével. Az első magyarázó változó a munkavállalók reálbérekkel kapcsolatos elvárásait testesíti meg, a termelékenység változása a munkaadók lehetőségeit határolja be a versenyképesség szempontjából, a munkanélküliség alakulása pedig a munkapiac kínálati oldalát jeleníti meg. A nominális átlagkereset egyenlete: 
$\mathrm{LOG}(\mathrm{W})=0,0783+0,6589 * \mathrm{LOG}(\mathrm{W}(-1) *(\mathrm{CPIEXPECT} / \mathrm{CPIEXPECT}(-1)))$ -

0,0497*LOG(PRODL(-1)) - 0,3575*URATE,

ahol URATE a munkanélküliség rátája.

Az infláció bérmegállapodásban való figyelembevételénél két módszer jöhet szóba. Ha a kormányzat antiinflációs politikája iránt nincs kellő bizalom, akkor a bértárgyalásokon a munkavállalói oldal a hátratekintő indexálást erölteti, azaz a béreket a múltbeli inflációs szint alapján igyekeznek emelni. Magyarországon a múlt század végéig ez volt a helyzet, ami az infláció csökkentésének egyik legnagyobb kerékkötője volt. Az infláció moderáltabbá válásával és ezáltal a következő évekre vonatkozó várakozások kiszámíthatóbbá válásával megnyílt az út az előretekintő indexálás bevezetése előtt, ahol is a bérköveteléseket a várt inflációhoz (amely a kormányzat antiinflációs elkötelezettsége mellett kisebb bérkiáramlást eredményez) igazítják, ezért az egyenletben is ez a változat szerepel.

Az egyenlet változói nem tartalmaztak egységgyököt, ezért nem alkalmaztam differenciázást. Ez elsősorban a nominális átlagkereset esetében volt meglepő, hiszen a pénzben mért változók ritkán stacionerek. Ugyanakkor az így kapott egyenlet lényegesen kedvezőbb illeszkedést produkált, mint a differenciázott bérekre felírt változat, ezért emellett döntöttem. A munkanélküliség kivételével valamennyi idősor heteroszkedasztikusnak bizonyult, ezért alkalmaztam a logaritmus transzformációkat. Az egyenlet valamennyi paramétere az eredeti becslésből származik, a kalibrálás során egyiken sem változtattam.

Modellünkben a munkakeresletet saját korábbi értéke mellett a teljes hozzáadott érték és a nominális keresettömeg határozza meg. A munkaerő-keresletnek az egzogén munkakínálattól való eltérése adja a munkanélküliséget. A munkaerő iránti keresletet leíró egyenlet a következő:

$\operatorname{LOG}(\mathrm{L})=1,345+0,799 * \operatorname{LOG}(\mathrm{L}(-1))+0,03 * \operatorname{LOG}(\mathrm{QGDP}(-1))-0,0128 * \operatorname{LOG}(\mathrm{D} 1 \mathrm{DOM}(-1))$,

ahol L a munkaerő-kereslet, QGDP a bruttó hazai termék összehasonlító áron, D1DOM a teljes hazai keresettömeg. 
Az egyenlet változói közül egyik sem bizonyult egységgyök-folyamatnak, az enyhe heteroszkedaszticitás kezelését követően valamennyi idősor stacionernek volt tekinthető. A keresettömeg esetében nem volt egyértelmü a döntési helyzet, a Dickey-Fuller statisztika pértéke ugyanis csak hajszállal volt 5 százalék alatt. Így még éppen el tudtam utasítani a egységgyök jelenlétét feltételező nullhipotézist a szokásos 5 százalékos szignifikanciaszint mellett, ugyanakkor a döntéshez tartozó esetleges másodfajú hiba valószínüsége az alacsony mintaelemszám miatt magasabb lehet a szokásosnál.

A modell korábbi verziójában még a reálkereset szerepelt magyarázó változóként a keresettömeg helyett, azonban annak magyarázó ereje folyamatosan csökkent, ahogy az idő múlásával hosszabbodtak az idősoraim. Ezért próbálkoztam a keresettömeg beépítésével, ami mellett elvi megfontolások is felhozhatók. Érdekes módon ennek inflációtól tisztított reálváltozata rendkívül gyenge eredményeket produkált, így maradtam az eredeti változatnál. A késleltetés indoka lehet, hogy amennyiben megemelkedik a munkaerö teljes költsége, a cégek először az egyéb költségek lefaragásával próbálkoznak, és csak ezt követően kezdenek elbocsátásokba.

A hozzáadott érték szerepeltetését elsősorban az a szokásos megközelítés indokolja, hogy a gazdaság növekedése esetén a vállalatok növelik a munkaerö-állományukat, a késleltetést pedig az, hogy a beinduló fellendülés előtt általában óvatos magatartást tanúsítva kivárnak ez érintettek. Mindkét egzogén magyarázó változó esetében a keresztkorrelációk vizsgálata is megerősítette az egy időszakos késleltetés alkalmazásának jogosságát.

Bár az egyenlet igen jó illeszkedést mutatott a múltbeli adatokon, mégsem fogadtam el az eredeti becslésből származó valamennyi paramétert a kalibrált modellre vonatkozóan. Ennek oka az volt, hogy épp a megfigyelési időszak legvégén kezdett nőni a becslési hiba, így attól tartottam, hogy a későbbiekben ez folyamatos és növekvő torzítást okozhat. Ennek vélhetően az a magyarázata, hogy a 90-es évek második felében beindult növekedést jelentős foglalkoztatás-bővülést indukált, ami a kezdeti felívelést követően érezhetően mérséklődött a 2000-es évek során. Megoldásként az egyenlet konstans paraméterét csökkentettem, de nem változtattam a magyarázó változók együtthatóin. 


\section{A jövedelemelosztás}

A nemzetgazdaságban megtermelt összjövedelmet - ami a GDP realizálási áron - a modell reálblokkjában számítjuk a végső felhasználási tényezők összegeként. Mivel az említett blokk reálkategóriákból áll, a számítások eredményeként a változatlan áras GDP-t (QGDP) kapjuk meg. A jövedelemelosztás blokk viszont nominális változókból indul ki, ezért a folyóáras GDP-re (XGDP) van szükségünk. Ennek meghatározásához a változatlan áras GDP-t tényezőnként alakítjuk folyóárassá, nincs tehát egységes GDP-deflátorunk. Ennek során négy árindexet használunk: fogyasztói (CPI), beruházási (PINV), export (PEXP) és import (PIMP) árindexeket.

Az alfejezet további részeiben, ha GDP-ről teszünk említést, mindig a nominális GDP-re gondolunk. Ezen kívül valamennyi megemlített tétel mögött zárójelben jelezzük, hogy a szóban forgó kategória milyen rövidítéssel szerepel az ESA '95 elszámolási rendszerben. Annak érdekében, hogy ezeket a rövidítéseket egyértelmüen elkülönítsük a modellben szereplő változónevektől, utóbbiak esetében a megnevezés utolsó néhány karaktere mindig a szóban forgó szektorra (esetleg azok valamely együttesére) utal. Például az elsődleges jövedelmek egyenlege az ESA '95 rendszerben B.5 jelzéssel szerepel. Ennek megfelelően a modellben a vállalati szektor elsődleges jövedelmeinek egyenlegét B5FIRM változónévvel jelöljük, ehhez hasonlóan a lakosságé B5HOUS, az államé pedig B5GOV. A három belföldi szektor együttes pozíciójának jele a modellben B5DOM, a külföldé B5ROW, az összes szektoré pedig B5SUM.

A szektoronkénti GDP (B.1) a gazdasági szféra jövedelemelosztási mérlege alapján, egzogén arányok szerint adódik a modell által nemzetgazdasági szinten meghatározott GDP alapján, és ez a forrása a szektorok kiadásainak.

A szektoronkénti GDP-ből levezethető az elsődleges jövedelmek alakulása. Az elsődleges jövedelmek a következő tényezőkből tevődnek össze:

Munkajövedelem (D.1) + Termékadók (D.2) - Terméktámogatások (D.3) + tulajdonosi jövedelem (D.4) + vegyes jövedelem (B.3).

A munkajövedelmet csak a háztartások kapják (D1SUM), és ez megegyezik a vállalatok (D1FIRM), az államháztartás (D1GOV), valamint a háztartások (D1HOUS) által kifizetett 
munkajövedelmek összegével (ami egyenlő a vállalatok, az államháztartás és a háztartások által kifizetett munkabérek és a munkáltatói társadalombiztosítási járulék összegével).

A termékadókat (D.2) az állam kapja és a vállalatok fizetik, a terméktámogatásokat (D.3) a vállalatok kapják és az államháztartás fizeti. Ezt korrigálni kell az egyéb termelési adók és támogatások egyenlegével és így alakul ki a termékadók és terméktámogatások egyenlege. Ezek a tételek megegyeznek a költségvetési mérlegben szereplő általános forgalmi adó és fogyasztási adó, ill. a fogyasztói árkiegészítés egyenlegével.

Ha a realizálási áras GDP-ből levonjuk az állam elsődleges jövedelmét, akkor kapjuk az ún. alapáron számított összjövedelmet, amely a realizálási áras GDP és az (ártámogatásokkal csökkentett) termékadók különbözeteként adódik.

A tőkejövedelmeket (D.4) mindegyik szektor kapja, és a jövedelemelosztásba itt lép be elöször a külföld. Eddig a pontig a hazai szektorok közti áramlások makrogazdasági szinten csak újraelosztást jelentenek. A háztartások tőkejövedelme empirikus kutatások alapján az utóbbi évtizedben a keresetek egy viszonylag fix aránya. Ez az arány azonban várhatóan fokozatos növekedésnek indul majd, ahogy a lakosság jövedelmi helyzetének javulásával a tőkejövedelmek szerepe is nőni fog. Az államháztartás tőkejövedelme pedig még belátható időn belül erősen negatív lesz, és az államadósságra fizetett kamat szintjének alakulásától függ. A vállalati szektor mérlegében a tőkejövedelem szintén erősen negatív érték, mivel két jellemző tétele a beruházási hitelek kamatterhe és a tulajdonosi kifizetések.

\section{A háztartások elsődleges jövedelme:}

B5HOUS = B1HOUS + D1SUM - D1HOUS + D4HOUS, ahol B5HOUS a háztartási szféra elsődleges jövedelme,

B1HOUS a háztartási szféra által megtermelt GDP,

D1SUM az összes kifizetett munkavállalói jövedelem,

D1HOUS a háztartási szféra által kifizetett munkavállalói jövedelem,

D4HOUS a háztartási szféra tulajdonosi jövedelme.

A D1HOUS értékét azért kell levonni, mert az csak a háztartási szférán belüli jövedelemátcsoportosítás, és nem más szektortól kapott jövedelem, ezért nem is része a háztartási szféra elsődleges jövedelmének. 
Az államháztartás elsődleges jövedelme:

$\mathrm{B} 5 \mathrm{GOV}=\mathrm{B} 1 \mathrm{GOV}-\mathrm{D} 1 \mathrm{GOV}+(\mathrm{D} 2 \mathrm{SUM}-\mathrm{D} 3 \mathrm{SUM})+\mathrm{D} 4 \mathrm{GOV}$,

ahol B5GOV az államháztartás elsődleges jövedelme,

B1GOV az államháztartás által megtermelt GDP,

D1GOV az államháztartás által kifizetett munkavállalói jövedelem,

D2SUM a termékadók összege,

D3SUM a terméktámogatások összege,

D4GOV az államháztartás tulajdonosi jövedelme.

\section{A vállalati szektor elsődleges jövedelme:}

B5FIRM = B1FIRM - D1FIRM - (D2SUM - D3SUM $)+$ D4FIRM, ahol B5FIRM a vállalati szektor elsődleges jövedelme,

B1FIRM a vállalatok által megtermelt GDP,

D1FIRM a vállalatok által kifizetett munkavállalói jövedelem,

D4FIRM a vállalati szféra nettó tulajdonosi jövedelme (jellemzően negatív érték).

Az elsődleges jövedelmek elosztása után következik a másodlagos jövedelemelosztás, amelynek főszereplője az államháztartás. Ennek során az állami jövedelemcentralizáció mértékének megfelelően az állam újraosztja a gazdaságban megtermelt jövedelmeket. Ennek fő eszközei a jövedelemadók (társasági adó, személyi jövedelemadó), a társadalombiztosítási járulékok, a gazdasági szféra egyéb adóbefizetései, valamint a lakossági transzferek. Ugyanakkor az államháztartás fizeti a pénzbeni és természetbeni társadalmi juttatásokat, és nyújt támogatásokat a gazdálkodó szervezeteknek.

Jövedelem- és vagyonadók: Ma Magyarországon a személyi jövedelemadó (D5HOUS) és a társasági nyereségadó (D5FIRM) a két legnagyobb tétel.

Társadalombiztosítási járulék (D.61): Itt jelenik meg a munkajövedelmekben egyszer már a lakosságnak elszámolt munkáltatói járulék és a munkavállalók által fizetett társadalombiztosítási járulék átcsoportosítása az államháztartáshoz (társadalombiztosítási alapok), illetve kisebb részben a vállalatokhoz (magán-nyugdíjpénztárak). 
Pénzbeli társadalmi juttatások (D.62): Itt kerül kimutatásra az államháztartás alrendszereiből (családi pótlék, munkanélküli segély, táppénz, nyugdíj, gyes, gyed), illetve a vállalatok által pénzben kifizetett juttatások összessége.

Egyéb folyó transzferek (D.7): Ennek részei a viszonzatlan átutalások, a nemzetközi szervezetekkel szembeni pénzáramlások, a háztartások közötti átutalások és az államháztartáson belüli átcsoportosítások. Ez a második pont, ahol a jövedelemelosztásba a külföld is bekapcsolódik.

Rendelkezésre álló jövedelem: Az állami redisztribúció eredményeként adódik a szektorok számára ténylegesen, pénzben rendelkezésre álló jövedelem (B.6), ami a nemzetgazdasági alanyok által felhasználható jövedelem értéke, és nemzetgazdasági szinten megegyezik az elsődleges jövedelmek összegével, de szektoronként attól eltér. Empirikusan igazolt tény, hogy ez az a jövedelemfogalom, amely leginkább kihatással van a háztartások fogyasztására, ebben a modellben is a lakossági rendelkezésre álló jövedelem szerepel a fogyasztás magyarázó változójaként.

A rendelkezésre álló jövedelmet a természetbeni társadalmi juttatásokkal (D.63) korrigálva kapjuk a korrigált rendelkezésre álló jövedelmet (B.7), ez azonban csak az állam és a lakosság között jelent jövedelemtranszfert.

A szektorok rendelkezésre álló jövedelmüket fogyasztásra és beruházásra fordíthatják, vagy megtakaríthatják. Elméletileg már ebbe a blokkba számít a korrigált rendelkezésre álló jövedelem magánnyugdíjak nettó tőkeváltozásával (D.8) való kiigazítása. Ez mindenképpen szükséges, hiszen ez a tétel nem tekinthető klasszikusan vett TB járuléknak, nem is fogyasztás, hanem a háztartások megtakarításának része.

A korrigált rendelkezésre álló jövedelemből (B.7) levonva az összes fogyasztást kapjuk a szektorok bruttó megtakarítását (B.8). Ezt a tőketranszferekkel (D.9) korrigálva marad a nettó vagyonváltozás (B.10), amely még nem tartalmazza a beruházásokra fordított összegeket.

A beruházások (pénzügyi) hatását figyelembe vevő mutató a nettó pénzügyi pozíció (vagy nettó megtakarítási/finanszírozási igény). Ez mutatja meg, hogy a jövedelemelosztás végén az egyes szektorok megtakarítói pozíciói hogyan alakulnak. 


\section{A kínálati oldal}

Egy olyan makromodell esetében, amelyet elsősorban hosszú távú előrejelzések készítésére szeretnénk használni, kiemelt jelentősége van a modell kínálati oldalának. Ez azért van így, mert a hosszabb távú prognózisok épp abban különböznek minőségileg is a rövidtávra vonatkozóktól, hogy az előrejelzési időszak alatt kínálati alkalmazkodást is feltételezünk.

A GDP kínálati oldalának meghatározására egy Cobb-Douglas típusú termelési függvényt használunk a vállalati szektorra, a többi szektor kínálata ehhez igazodik:

$$
Q S G D P=T F P \cdot Q K^{\alpha} \cdot L^{1-\alpha}
$$

ahol QSGDP jelöli a GDP kínálati oldalát összehasonlító áron,

QK a tőkeállomány mennyisége összehasonlító áron,

L a felhasznált munkaerő mennyisége, ami azonos a munkakereslettel, arra a feltételezésre építve, hogy a gazdaságban természetes körülmények között munkanélküliség van (munkanélküliség természetes rátája). Megjegyezzük, hogy modellünkben a munka kínálata egzogén, de az elöbbiek értelmében mindig meghaladja a munka keresletét.

TFP a 2.2 pontban már említett teljes tényező termelékenység, ami a termelési függvényben szereplő szorzótényező. A Cobb-Douglas termelési függvény eredeti formájában ez egy konstans. A növekedési modellek korábbi változataiban a TFP egy időben változó egzogén paraméter. Ezekben az esetekben a TFP alakulását nem magyarázzák a modellben szereplő változók, lényegében csak a technikai haladástól függ. Az általunk használt modellben azonban endogén technikai fejlődést tételezünk fel, vagyis a TFP is endogén változó. Magyarázó változói: a kormányzat által saját forrásokból és az EU-transzferekből az alapkutatásra (fun01dsum), műszaki fejlesztésre (FUN01esum), oktatásra (FUN04sum) és egészségügyre (FUN05sum) fordított kiadások, továbbá a kormányzati szektor beruházásainak aránya a változatlan áras GDP-hez (funqinvpu), valamint az EU-transzferek azon része, mely tőketranszferként jelenik meg a vállalati szektorban (D9EUSUMF). 
A TFP egyenlete a következő:

$\mathrm{TFP}=1,145+$ par_tfp* $(0,08 *$ fun01dsum(-1)+0,08*FUN01esum(-1)+

$0,093 *$ FUN04sum(-1)+0,093*FUN05sum(-1)+0,07*funqinvpu(-1)+

$0,05 * \mathrm{D} 9 \operatorname{EUSUMF}(-1)+0,603 * \mathrm{TFP}(-1))$

A TFP kiszámítása eleve komplex feladat, pedig a kérdés egyre megkerülhetetlenebb, tekintettel arra, hogy az elemzések többsége szerint e tényező súlya egyre nagyobb a GDP növekedésében. ${ }^{47}$ A vonatkozó irodalomból kiolvasható, hogy a TFP-t elsősorban olyan faktorok növelik, amelyek segítik a technikai haladást, az új módszerek, know-how-k átvételét, javítják a munkaerő felhasználásának hatékonyságát, növelik a versenyképességet a munkaszervezés javításával illetve új menedzsmentmódszerek alkalmazásával. Javítja a TFP-t az is, ha nő a munkaerő-állomány munkaképessége, ami jelentheti a képzettség valamint az egészségügyi állapot javulását. Mindezen szempontok alapján valamint a rendelkezésre álló adatok körét figyelembe véve döntöttem a fenti változócsoport alkalmazása mellett.

A paraméterbecslések elött elő kellett állítanom a TFP adatsorát, melyet a termelési függvény segítségével számítottam vissza. ${ }^{48}$ Mivel a rendelkezésre álló idősor a szokásosnál is rövidebb volt, a becslés tulajdonságainak javítása érdekében olyan módon csökkentettem a becsült paraméterek számát, hogy két-két hasonló tartalmú változó esetében (müszaki és alapkutatás valamint az egészségügyi és oktatási kiadások) közös paramétereket becsültem. Ez nyilvánvalóan erőteljes korlátozást jelent, azonban az egy magyarázó változót tartalmazó egyenletek eredményei arra utaltak, hogy viszonylag hasonló ezen változópárok TFP-re gyakorolt marginális hatása.

A korábbi bírálatok hatására alkalmaztam a késleltetéseket, bár ezt az idősorok rövidsége miatt nem lehetett korrekt keresztkorrelációkkal alátámasztani. Ugyanakkor logikusnak tűnik, hogy a magyarázó változók - jellegükből adódóan - késleltetve és több éven keresztül hatnak a TFP alakulására. Utóbbi indokolta a késleltetett eredményváltozó bevonását a magyarázó változók közé, ez ugyanis hasonló hatású ahhoz, mintha a magyarázó változókra egy exponenciálisan gyengülő késleltetési struktúrát alkalmaztam volna.

\footnotetext{
${ }^{47}$ Lásd pl: Danquah, M. - Moral-Benito, E. - Quattara, B. [2011]

${ }^{48}$ A vállalati szféra GDP-je, tőkeállománya, és az ott felhasznált munkaerő adott volt. Az $\alpha$ paraméter értékét a tankönyvekben is általánosan használt 0,3-as értékre állítottam be. Így maradékként adódott a TFP.
} 
A par_tfp a modell egyetlen olyan paramétere, amely esetében megengedtem, hogy időben változzon. Erre azért volt szükség, hogy kezelni tudjam az olyan nem számszerüsíthető eseményeket (elsősorban kormányzati intézkedéseket), amelyek hatással lehetnek a TFP alakulására. Ugyanakkor igyekeztem nem visszaélni ezzel a lehetőséggel, alapesetben a par_tfp időben változatlan ütemben növekszik. Ezt tekinthetjük egyfajta olyan autonóm növekedésnek, amit a TFP egyenletében szereplő változók nem képesek magyarázni.

A tőkeállomány a következő séma szerint határozódik meg:

$\mathrm{QK}=\mathrm{QK}(-1) *(1-\mathrm{AMORT})+\mathrm{QINV}(-1)$,

ahol AMORT a tőkeállomány évi átlagos amortizációja,

QINV a teljes nemzetgazdasági beruházás. ${ }^{49}$

Az adott évi tőkeállomány tehát az előző évi tőkeállomány amortizációval csökkentett értéke és a beruházás az összegeként adódik. Ez a metódus az előrejelzési időszakra vonatkozik, ebben az esetben tehát az amortizáció egzogén (más szerzők ${ }^{50}$ és nemzetközi tapasztalatok alapján hosszabb távon ennek mértékét 6-8\% körülire becsültük). A tényidőszakra ezzel szemben adottnak vettük a tőkeállományt, és a fenti összefüggésből a szóban forgó évre vonatkozó amortizációt határoztuk meg. A tőkeállomány (múltbeli) értékére a hivatkozott tanulmány is készít becsléseket, sőt annak közeljövőbeli alakulását is előrejelzi. Eszerint a magyar gazdaság tőkeintenzitása jelenleg elmarad a fejlettebb gazdaságokban megszokott mértéktől, az ott megszokott 200-220\% helyett csak a GDP mintegy 170\%-át tette ki a 90-es évek végén. A tanulmány szerzői évente 1-2 százalékpontos növekedést tartanak elképzelhetőnek, aminek az előrejelzési időszakra vonatkozó becsléseink sem mondanak ellent.

A keresleti és kínálati oldal összevetéséből számítjuk a makroszintű kapacitáskihasználtságot. Elméleti megfontolások és korábbi tapasztalataink alapján meghatároztuk a kapacitáskihasználtság természetes mértékét. Ez alatt egy olyan szintet értünk, amely mellett a vállalatok feszültségektől mentesen képesek az ingadozó kereslet kielégítésére. Ez

\footnotetext{
${ }^{49}$ Ebben az esetben lényegében azzal az egyszerüsítéssel éltem, hogy feltételeztem, a beruházások egy adott évben maradéktalanul megvalósulnak, a következő évben pedig teljes értékükkel növelik a tőkeállományt.

${ }^{50}$ Lásd pl.: Darvas Zs.-Simon A.: A növekedés makrogazdasági feltételei - Gazdaságpolitikai alternatívák, MNB Füzetek, 1999/3
} 
természetesen iparáganként szóródik, sőt időben is változhat. Modellünkben 80\%-ra állítottuk be a kapacitáskihasználtság természetes mértékét.

A kínálati alkalmazkodás a természetes mértéktől való eltérés függvénye. Ennek a modellbe történő illesztése során azzal a feltételezéssel éltünk, hogy amennyiben a kapacitáskihasználtság ezt meghaladja, akkor az közvetlenül hat a következő két változóra.

1. Az importot emeli, hiszen a túlkereslet levezetésének ez az egyik módja. A nagyobb import csökkenti a kereslet oldali GDP-t, vagyis az egyensúly irányába mozdulunk el.

2. Növeli a beruházásokat, mivel a vállalatok az élénk keresletet érzékelve kapacitásaik bővítését határozzák el. Az adott évi többletberuházás viszont a következő évtől kezdve nagyobb tőkeállományt eredményez, és így emelkedik a makroszintü kínálat (kínálati alkalmazkodás). Mindez szintén a túlkereslet megszünésének irányába hat.

Ez tehát az a visszacsatolási mechanizmus, amelynek során a kínálati oldal dinamikusan képes alkalmazkodni a kereslethez. Ezzel a potenciális GDP (a kínálat) egy újabb elemét endogenizáltuk - a munkaerő-kereslet a másik endogén tényező -, mindössze a kitevő paramétere egzogén, amit azonban nem is indokolt bevonni a modellbe.

\subsection{Az állam szerepe}

A gazdaságban betöltött jelentős pozíciója, és a gazdasági struktúra alakításában játszott szerepe miatt külön érdemes tárgyalni az állam szerepét. Magyarországon a gazdaságpolitika szerepe különösen meghatározó lesz a következő néhány évben, mivel a politika jelöli ki az EMU csatlakozásig vezető pályát, és döntéseivel jelentős mértékben meghatározza számos makrogazdasági változó alakulását.

Az államháztartás helyzetét alapvetően befolyásolja, hogy a korábbiakban felhalmozott jelentős államadósság kamatterhei miatt az államháztartás nettó megtakarítói pozíciója még sokáig negatív lesz, az elsődleges többlet ugyanis elmarad a kamatkiadásoktól. 
Az államháztartási hiány alacsonyan tartása több okból is elkerülhetetlen. Egyrészt a maastrichti szerződés szerint nem csak a Gazdasági és Monetáris Unióhoz csatlakozó országok, hanem egyetlen EU-tagállam deficitje sem haladhatja meg tartósan a GDP 3\%-át, sőt a GMU harmadik szakaszában ${ }^{51}$ résztvevő országoknak a Stabilitási és Növekedési Egyezmény alapján kiegyensúlyozott költségvetésre kell törekedniük.

A magas államháztartási deficit csökkentése azért is indokolt, mert az állami centralizáció mértékének csökkentése és az államháztartási hiány visszafogása többleterőforrásokat hagy a magánszektorban, amely azt elméletileg hatékonyabban használja fel. Itt érdemes még megjegyezni, hogy Oblath (1998) szerint a 3 százalékos nominális deficitráta csak akkor nem vezet a 60 százalékos adósság/GDP arány növekedéséhez, ha a gazdasági növekedés eléri az 5 százalékot.

Természetesen egy felzárkózó - vagy felzárkózásban reménykedő - gazdaságban szükséges az infrastrukturális beruházások állami finanszírozása, a nagy ellátórendszerek reformja és az átalakulás veszteseinek szociális támogatása, amelyek jelentős költségvetési terhet jelentenek. Az állam belső eladósodásának egy kis nyitott, a tőkeáramlást liberalizáló országban a magánmegtakarítás szintje ugyan nem szab határt, de a lakosság és a vállalatok túlzott mértékü külföldi hitelfelvétele is a pénzügyi stabilitás gyengüléséhez vezethet, ahogy ezt az utóbbi években ez európai valutaválság is jelzi.

\subsection{Az EU-transzferek a modellben}

Már az elmúlt időszakban jelentős támogatás érkezett hazánkba az Európai Unió Strukturális és Kohéziós Alapjaiból, így fontossá vált ezeknek a transzfereknek a beépítése a modellbe. Mivel a teljes tényező termelékenység endogenizálása már korábban megtörtént, ezáltal lehetővé vált, hogy a transzferek bizonyos területeken felhasznált mértéke ezen keresztül hatást gyakoroljon a növekedésre és a többi makrogazdasági változóra.

\section{Hatásmechanizmus}

\footnotetext{
${ }^{51}$ A GMU 3. szakasza a közös valuta bevezetésével veszi kezdetét.
} 
Az EU-transzferek felhasználási területeit három fő kategóriára lehet osztani, ezek az infrastruktúra, humántőke és termelőszektornak adott transzferek (ez a csoportosítás a nemzetközi gyakorlathoz hasonlóan történt, ld. QUEST, HERMIN modellek). A modell kínálati oldal által meghatározott, így ahhoz, hogy a transzferek nagysága vagy megoszlásának megváltozása hatást gyakoroljon a növekedésre, be kellett építeni a termelési függvénybe, és ezt a TFP-n keresztül valósítottuk meg.

A közösségi beruházás egyenletében megjelennek az Európai Unió által nyújtott tőketranszferek, melyeket az infrastruktúrára, humántőkére, és termelő vállalatoknak nyújtott támogatásra lehet elkölteni, és ehhez adódik hozzá az állami társfinanszírozás nagysága is.

Az államháztartás funkcionális megoszlását alkalmaztuk a kormányzati kiadások modellezésére, és az így létrejövő funkcionális kiadási tételek szerepelnek az ESA kategóriáinak magyarázó változói között. Az EU transzferek már említett három területen történt felhasználását megpróbáltuk beazonosítani az egyes funkcionális tételeknek, és ez hozzáadódik a végső kiadási tételnél a kormányzati kiadásokhoz, melyek az uniós támogatásoktól függetlenül megvalósulnak. Ez alapján az állami müködési funkciókon belüli általános közösségi szolgáltatások föcsoporton belüli két csoport, az alapkutatásra és a müszaki fejlesztésre fordított kiadások a termelőszektornak nyújtott támogatásnak feleltethető meg, a jóléti funkciókon belüli oktatási tevékenységek és szolgáltatások főcsoport a humántőke fejlesztésére nyújtott uniós támogatásoknak. A termelési függvényben szereplő teljes tényező termelékenységet, mely a technológiai haladást, fejlödést jeleníti meg, az alapkutatásra, müszaki fejlesztésre, oktatásra és egészségügyre költött kormányzati kiadások, az ezeken a területeken felhasznált uniós támogatások, és a hozzájuk kapcsolódó állami társfinanszírozás, továbbá a közösségi beruházások segítségével magyarázzuk. A felhasznált uniós támogatások nagysága egzogén, és a 2007-2013-as programozási periódusban szereplő érték alapján adtuk meg az ebben az időszakban történő felhasználás mértékét, azonban - az elmúlt időszak tapasztalatai alapján - azzal a feltételezéssel éltünk, hogy nem sikerül a teljes rendelkezésre álló mennyiséget felhasználni. Magyarország a 2004-2006-os időszakra rendelkezésre álló fejlesztési források teljes összegének nagyjából 80 százalékát tudta lehívni 2008 végéig az $n+2$ szabály alapján. ${ }^{52}$ Összességében arra számítunk, hogy a rendelkezésre álló forrásoknak ennél valamivel kevesebb, mintegy 75 százalékát sikerül felhasználni a

\footnotetext{
${ }^{52}$ Az uniós forrásokat a tárgyévet követő második év végéig lehet lehívni.
} 
jelenleg futó programozási periódusban. További feltételezés, hogy a 2007-2013-as programozási időszakot követően is érkezik támogatás Magyarországra, a transzferek beáramlásának nem szakad vége (szemben például a HERMIN modell feltételezésével [Bradley, Morgenroth, 2004]).

Az eddig vázolt hatásmechanizmusok eredményei a következő változókban csapódnak le.

- Az EU-tól kapott többletforrás csökkenti az ország külső finanszírozási igényét, és hatására megváltozik a gazdasági szektorok közötti jövedelemelosztás szerkezete is.

- Az államháztartás kiadásainak szerkezete is módosul, az EU által támogatott területekre több költségvetési pénz jut.

- A támogatások feltételéül szabott költségvetési társfinanszírozás következtében romlik az államháztartás egyenlege, amit azonban ellensúlyozhat, hogy az állam esetlegesen kevesebbet fordít ezekre a területekre, mint EU támogatások nélkül tette volna.

- Az EU-tól kapott tőketranszferek bővítik a beruházásokat, és így a tőkeállományt is, ami pedig a kínálat növekedését eredményezi.

- A humán erőforrások fejlesztését szolgáló programok szintén a kínálati függvényen keresztül javítják a növekedési kilátásokat, hatásuk közvetlenül a TFP emelkedésében csapódik le. 


\section{Az EU-transzferek felhasználási szerkezetének makrogazdasági hatásvizsgálata}

Ebben a fejezetben először ex post elemzéssel vizsgálom meg a modell előrejelző képességét, majd részletesen bemutatok egy, a modell felhasználásával kapott alappályát. Ezt követően két alternatív szcenáriót is számszerüsítek, és az egyes makrogazdasági pályákban tapasztalt eltérések elemzésével érzékeltetem, hogyan hat az EU-transzferek mennyisége és szerkezete a hosszú távú gazdasági pályára.

\subsection{A modell stabilitásának vizsgálata}

Lényeges kérdés, hogy a modell hogyan reagál az esetleges sokkokra, azok hatásai hosszú távon lecsengenek-e vagy épp felerősödnek. A kérdésre részben választ adnak a gyakorlati alkalmazások eredményei, a szecenárió-elemzések során ugyanis jelentősen változtattam az egzogén feltételrendszeren, ami a sztochasztikus egyenletekben egyfajta sokként jelentkezett. A dolgozatban közölt és a korábbi futtatások során a modell meglehetős stabilitásról tett tanúbizonyságot, az egyszeri sokkok hatása idővel fokozatosan gyengült. A tartós sokkok (szinteltolások) az eredeti makropálya elmozdulását eredményezték, azonban ilyen esetekben sem tapasztaltam időben felerősödő hatásokat.

A sokkokkal szembeni stabilitás vizsgálatára ökonometriai módszerek is léteznek, ilyen esetekben elsősorban az impulzus válaszfüggvényeket szokás alkalmazni. Ezek lényege, hogy egy adott egyenlet maradékváltozójában jeleníti meg a sokkot, és ennek hosszú távú hatását mutatja be valamennyi endogén változóra vonatkozóan. Az impulzus válaszfüggvények meghatározása alapesetben rendkívül számolásigényes feladat, a gyakorlatban statisztikai programcsomagok segítségével számítják a hozzájuk tartozó értékeket. Az általam alkalmazott modell azonban rendkívül összetett, a standard programcsomagok viszont csak egyszerübb és szokványosabb struktúrájú modellek esetében támogatják az impulzus válaszfüggvények számítását. Bár az EViews programcsomagot kifejezetten idősorok elemzésére fejlesztették ki, és ez az egyik legjobban kidolgozott ökonometriai szoftver, az 
impulzus válaszfüggvényeket közlését csak VAR modellek esetében ajánlja fel. Ezért úgy döntöttem, hogy a legfontosabb sztochasztikus egyenletek sokkokra adott reakciót ilyen környezetben vizsgálom. Bár egy ilyen elemzés nem azonos a modell egészére végzett teszteléssel, mégis jól illusztrálja, hogy mennyire ellenállóak a modell egyenletei az esetleges sokkokkal szemben.

A VAR modelleket az egyes egyenletek valamennyi (eredmény- és magyarázó) változójára írtam fel, de az impulzus válasz függvényeket értelemszerűen csak az eredményváltozókra közlöm. Négy egyenletre mutatom be a válaszfüggvényeket, mindegyik esetben valamennyi magyarázó változóra vonatkozóan. A munkaerö-kereslet esetében ebbe beleértem az eredményváltozó késleltetett értékét is, hiszen az az eredeti egyenletben is szerepelt.

\section{Vásárolt fogyasztás}

Response to Cholesky One S.D. Innovations \pm 2 S.E.

Response of LOG(QCPUR) to DEPORATE/CPI ${ }^{*} \mathrm{CPI}(-1)$

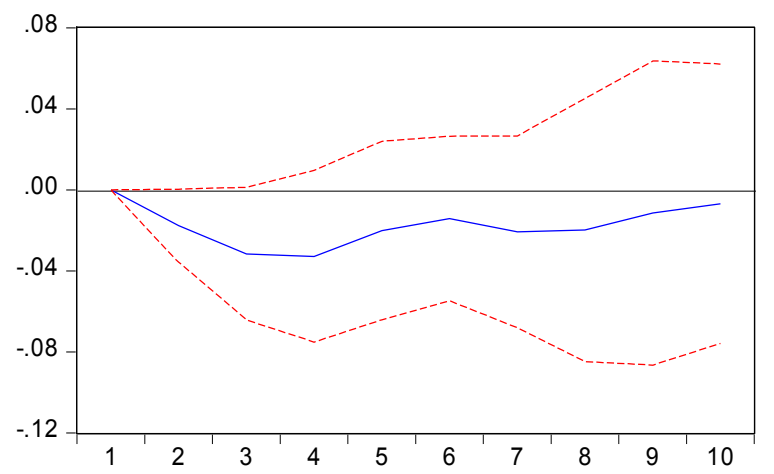

Response of LOG(QCPUR) to LOG(B6HOUS)

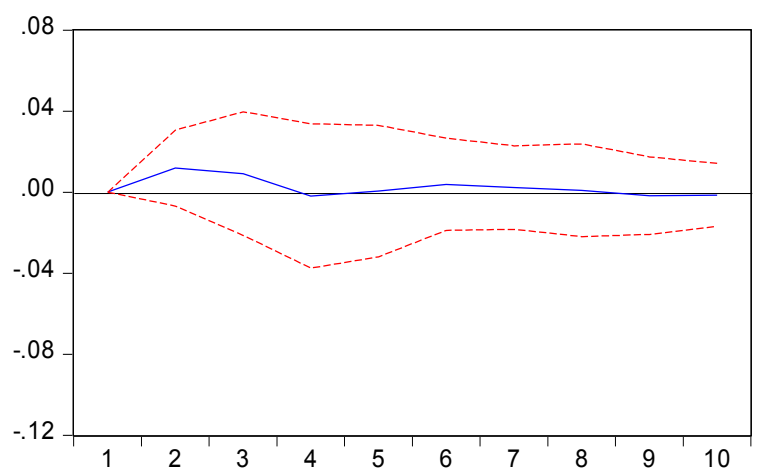




\section{Export}

2. sz. ábra

Response to Cholesky One S.D. Innovations \pm 2 S.E.

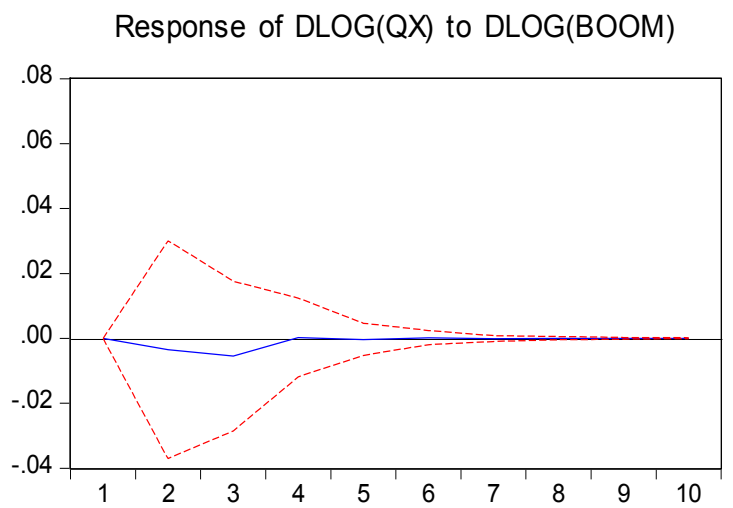

Response of DLOG(QX) to LOG(DIHEU)

Response of DLOG(QX) to DLOG(ERATEEU/D1DOM*L)

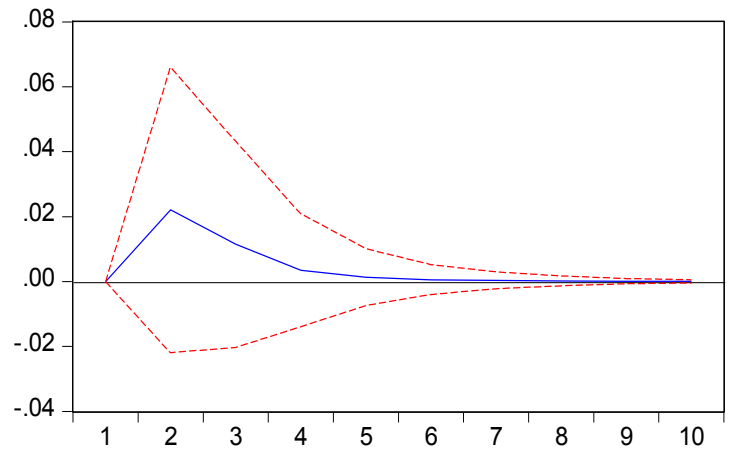

Fogyasztói árindex

3. sz. ábra

Response to Cholesky One S.D. Innovations \pm 2 S.E.

Response of DLOG(PPIFT) to DLOG(PRODL)

Response of DLOG(PPIFT) to DLOG(W)
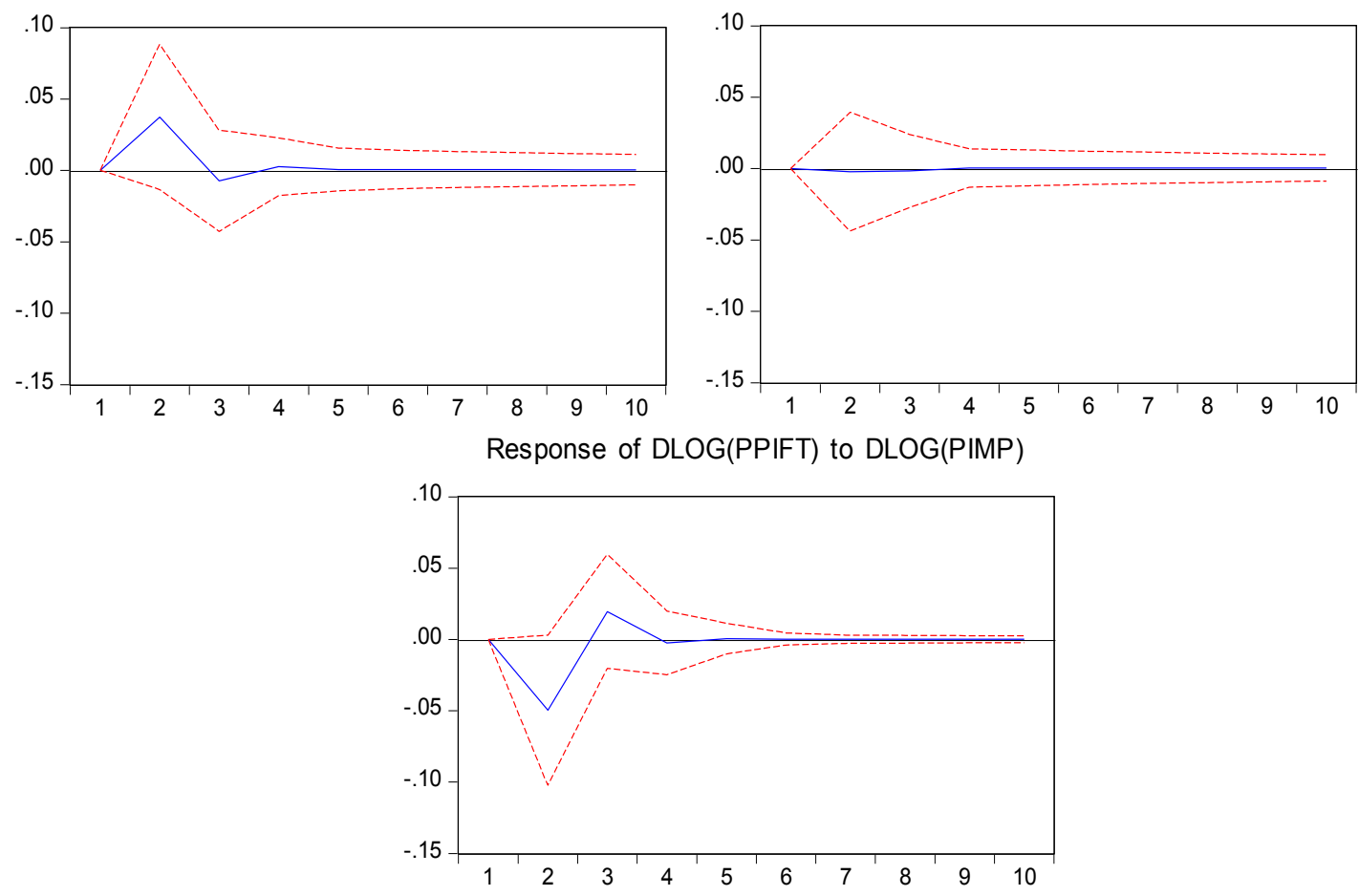


\section{Munkaerö-kereslet}

4. sz. ábra

Response to Cholesky One S.D. Innovations \pm 2 S.E.

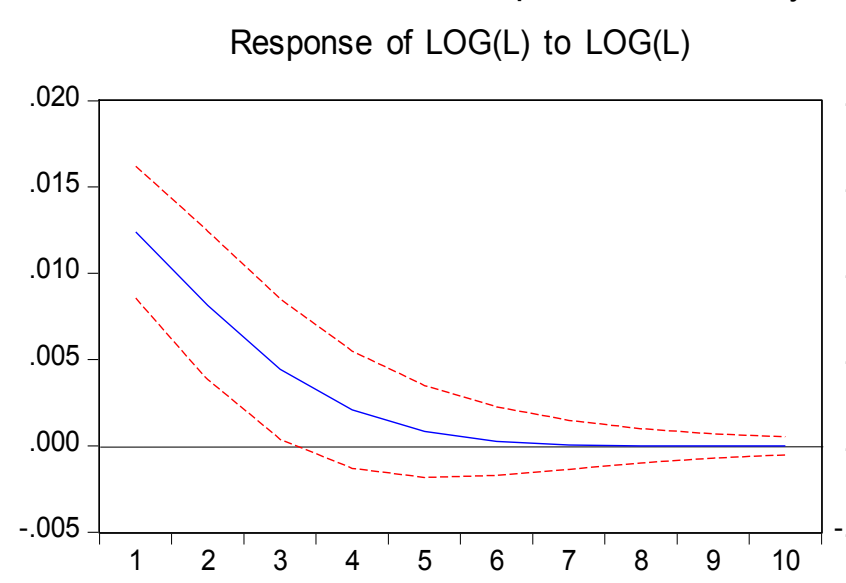

Response of LOG(L) to LOG(QGDP)

Response of LOG(L) to LOG(D1DOM)

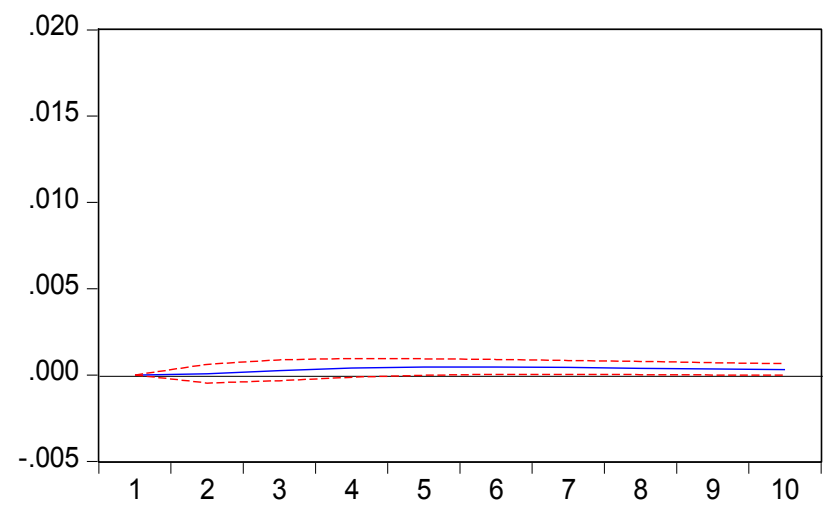

Az impulzus válaszfüggvények mind a négy esetben azt mutatják, hogy a sokkoknak az eredményváltozóra gyakorolt hatása folyamatosan gyengül, néhány időszak elteltével általában minimálisra csökken. A vizsgált egyenletek tehát stabilnak tekinthetök, nem tartalmaznak öngerjesztő visszacsatolásokat.

\subsection{A modell elörejelzö-képességének vizsgálata}

Az ex post elemzés módszere a modellek előrejelző képességének vizsgálatára szolgál. Az eljárás első lépésében a megfigyelési időszakot két részre bonjuk. Az elsőt tekintjük mintaidőszaknak, ennek adatai alapján becsüljük meg a modell paramétereit. Ezután az így megbecsült modell segítségével előrejelzést készítünk a megfigyelési időszak fennmaradó részére (ez esetünkben 5 évet jelentett). Az így kapott becsléseket egybevetjük a tényleges 
adatokkal, ennek pontossága alapján mondhatunk véleményt modellünk becslési tulajdonságairól.

A módszer előnye, hogy - szemben a hagyományos illeszkedési mutatók, például az $\mathrm{R}^{2}$ számításával - ilyenkor az előrejelzett értékekkel összehasonlított tényleges értékeket nem használjuk fel a paraméterbecslések során. Ennek köszönhetően reálisabb képet kaphatunk a modell előrejelző képességéről, hiszen egy modell jobban illeszkedik azokhoz az adatokhoz, amelyeken paramétereinek becslése alapszik. Az eljárás hátránya viszont az, hogy rövidül a becslési időszak, ami növeli az elörejelzés bizonytalanságát.

Ex post elemzésekben az előrejelző képességet az átlagos abszolút százalékos eltérés (Mean Absolute Percentage Error, MAPE) segítségével szokás számszerüsíteni. Ez a mutató azt fejezi ki, hogy a becsült és a tényleges értékek közötti eltérés abszolút értéke átlagosan hány százaléka a valódi adatnak. Használatos még az átlagos abszolút eltérés is (Mean Absolute Error, MAE), amely természetes mértékegységben fejezi, hogy mekkora az átlagos abszolút különbség a becsült és a tényleges érték között.

Az ökonometriai programcsomagok általában közlik még a Theil együtthatót, valamint annak megoszlását. A Theil mutató kisebb értéke jelzi a jobb illeszkedést, ezen belül a kedvezőbb eset pedig az, ha a hiba minél kisebb hányada adódik torzításból.

Modellünkben a megfigyelési időszak 1995-től 2011-ig tart, ezen belül a becslési időszak pedig 2006-ig. Az ex post elörejelzések tehát az 2007-2011 közötti időszakra készültek. A kapott eredményeket a 2. számú táblázat tartalmazza. 
Az ex-post elemzés eredményei

\begin{tabular}{|c|c|c|c|c|c|}
\hline \multirow{2}{*}{ Egyenlet } & \multirow{2}{*}{ MAPE } & \multirow{2}{*}{$\begin{array}{c}\text { Theil } \\
\text { együttható }\end{array}$} & \multicolumn{3}{|c|}{ Theil együttható megoszlása (százalék) } \\
\hline & & & Torzítás & Variancia & Kovariancia \\
\hline Vásárolt fogyasztás & 7,66 & 0,041 & 44 & 26 & 30 \\
\hline Vállakozások beruházásai & 5,06 & 0,029 & 7 & 8 & 85 \\
\hline Export & 2,99 & 0,021 & 7 & 10 & 83 \\
\hline Import & 2,78 & 0,017 & 3 & 93 & 4 \\
\hline GDP & 1,97 & & & & \\
\hline Ipari termelö árak & 6,8 & 0,043 & 52 & 41 & 7 \\
\hline Fogyasztói árak & 2,89 & 0,024 & 40 & 50 & 10 \\
\hline Munkakereslet & 0,57 & 0,003 & 5 & 1 & 94 \\
\hline Átlagkereset & 12,05 & 0,063 & 69 & 29 & 2 \\
\hline
\end{tabular}

Az említett mutatókat azokra az endogén változókra számítottam ki, melyekre valódi viselkedési egyenletet írtam fel. Kiegészítésként szerepeltetem a GDP-re vonatkozó MAPE mutatót, amit külön kellett kiszámítanom, ugyanis ebben az esetben nem becsült egyenletből kaptam az elörejelzéseket. Így a GDP-re Theil együtthatót nem tudtam közölni. A többi változó esetében az eredeti becsült egyenletekből származtattam a táblázatban szereplő mutatókat. Esetünkben a MAPE értékek jellemzően 2 és 7 százalék körüli értékeket vettek fel, ami kifejezetten jó illeszkedésnek számít. Például az export esetében kapott 2,99 százalékos eredmény azt jelenti, hogy a vizsgált idöszakban - azaz 2007 és 2011 között - átlagosan ennyivel tértek el a tényleges értékek a modell által becsült számoktól. Két kiugró értéket kaptam, a munkaerő-kereslet mindössze 0,57, míg a legrosszabb eredményt produkáló átlagkereset 12,05 százalékos MAPE mutatót jelzett.

A Theil együttható is többnyire alacsony értékeket vett fel, a torzítás hányada pedig majdnem minden esetben 50 százalék alatt maradt, sőt az egyenletek felében szinte elhanyagolható mértékü volt. Így ez alapján is elfogadhatónak tekinthető a modell előrejelző-képessége. 


\subsection{Az alapszcenárió eredményei ${ }^{53}$}

A modellbecslés alapváltozatában a modell egzogén változói a következők szerint alakultak:

- A BOOM (külső kereslet) változó értéke évente 1,5-2,5 százalékkal nő.

- Az export árindex (WPIEXPEU) és az import árindex (WPIIMPEU) egyaránt évente 1,53 százalékkal nő.

- Az árvárakozások indexe (CPIEXPECT) alapján 2013-tól fokozatos dezinfláció várható, és a várt inflációs ráta 3 százalék körül stabilizálódik. Ennek magyarázata, hogy modellünkben az árakra vonatkozóan racionális várakozásokat tételeztünk fel, vagyis a gazdasági szereplök hosszú távon az árstabilitásnak megfelelö fogyasztói árindexre számítanak. Utóbbit a 3 százalékos jegybanki céllal azonosítottam.

- A betéti és hitelkamatlábak (DEPORATE, LOANRATE) 2014-ig fokozatosan konvergálnak az aktuális eurókamatokhoz, 2015-től elérik azokat (4 illetve 6 százalék).

- A természetbeni társadalmi juttatások (D63) értéke összehasonlító áron évente átlagosan 2 százalékkal nő.

- A közvetlen külföldi tökebefektetések (DIHEU) értéke a 2011-ben elért mélypontot követően fokozatosan emelkedik, de csak a vizsgált időszak végére közelíti meg a korábban jellemzőnek mondható 3-4 milliárd euró körüli szintet.

- A ténylegesen felhasznált EU transzferek értéke eléri a GDP 2,5-3 százalékát.

Modellem alapváltozatában azzal számoltam, hogy a hazai valuta árfolyama hosszabb távon enyhén erősödik az euróhoz képest, és 280 Ft/euró szint körül stabilizálódik. A jelenlegi helyzetből kiindulva 2020-ig nem számítok az uniós valuta hazai bevezetésére, ám amennyiben ez mégis megtörténne, értelemszerüen az említett 280-as árfolyamot tekintem mérvadóan. A modell jelenlegi keretei között a két eset között nincs számottevő eltérés. ${ }^{54}$

Az EU-transzferekkel kapcsolatos kiinduló feltevések az alábbiak:

\footnotetext{
${ }^{53}$ A modellszimulációs időszak 2012-2020. A modellszámítások 2012 októberében fejeződtek be.

${ }^{54}$ A hosszú távú makropálya szempontjából ugyanis csak az árfolyamnak van jelentősége, a modell ugyanis nem számol az árfolyamkockázat eltűnéséből vagy az átváltási tranzakciók költségeinek megszűnéséből adódó megtakarításokkal.
} 
- A Magyarország számára elérhető 25,3 Mrd euró értékü támogatási keret 70 százalékát sikerül felhasználni a 2007-2013-as programozási periódus alatt.

- Az ezt követő évek során is érkeznek transzferek, azonban az évente felhasználható keret kismértékben csökken.

- A beérkező transzferek felhasználási területeit három kategóriába lehet sorolni, az ezek közti megoszlás a következő: az alapok 63 százalékát infrastrukturális beruházásokra, 17 százalékát humántőke-beruházásokra, 20 százalékát pedig termelő vállalatoknak nyújtott támogatásokra fordítják. ${ }^{55}$

- A kormányzati kiadások szerkezeténél az előző évi kiadások funkcionális megoszlását vettem figyelembe, és azt az egész időszak alatt állandónak tekintettem.

Annak érdekében, hogy az alternatív szcenárókkal kapcsolatos elemzések kellő mélységüek lehessenek, az alappályát is alaposan érdemes bemutatni. Ezért a következőkben részletesen elemzem az általam legfontosabbnak tartott gazdasági mutatók alakulását.

\section{A gazdasági növekedés}

Az 1997-2006 közötti időszakban a magyar gazdaság folyamatosan és gyors ütemben növekedett. 2007-től azonban megtorpant a növekedés, ami elsősorban a 2006 öszén megkezdett fiskális kiigazítással magyarázható. 2008 első félévére a gazdaság kiheverte a költségvetési megszorítások sokkját, és az addig 1 százalék alatti növekedési ütem emelkedni kezdett. 2008 őszén azonban kitört a globális hitelválság, aminek következtében 2009-ben jelentősen visszaesett a magyar GDP. 2010-től megindult ugyan a növekedés, de annak üteme jelentősen elmaradt a 2007 előttitől. 2012-ben újra recesszióba fordult a magyar gazdaság, és ami ennél is elszomorítóbb, a jövőbeli gyors növekedés feltételei sem látszanak.

A modellbecslések alapján idén minimális, jövőre mérsékelt növekedés várható, és a későbbiekben sem lehet számítani a korábban megszokotthoz közelítő tempóra. A hosszú távú növekedési pálya 2017-ig 1-2, azt követően 2-3 százalék közötti éves növekedést mutat, csak az utóbbi jelent az Európai Unió legfejlettebb gazdaságainál magasabb dinamikát. Ez lényegében az eredményezi, hogy az évtized végéig alig kerülünk közelebb az unió átlagához,

55 A transzferek három beruházási terület közti megoszlása Bradley - Morgenroth [2004] tanulmánya alapján történt 
akár egy teljes évtizedre is leállhat a magyar gazdaság konvergenciája. Ennek oka elsősorban az, hogy az utóbbi időszakban épp a TFP-t meghatározó tényezők rovására történnek a költségvetési átrendezések, és az alapváltozatban kénytelen voltam feltételezni, hogy ez a tendencia a jövőben sem változik meg gyökeresen.

A bruttó hazai termék növekedése százalékban

(az előző évhez képest)

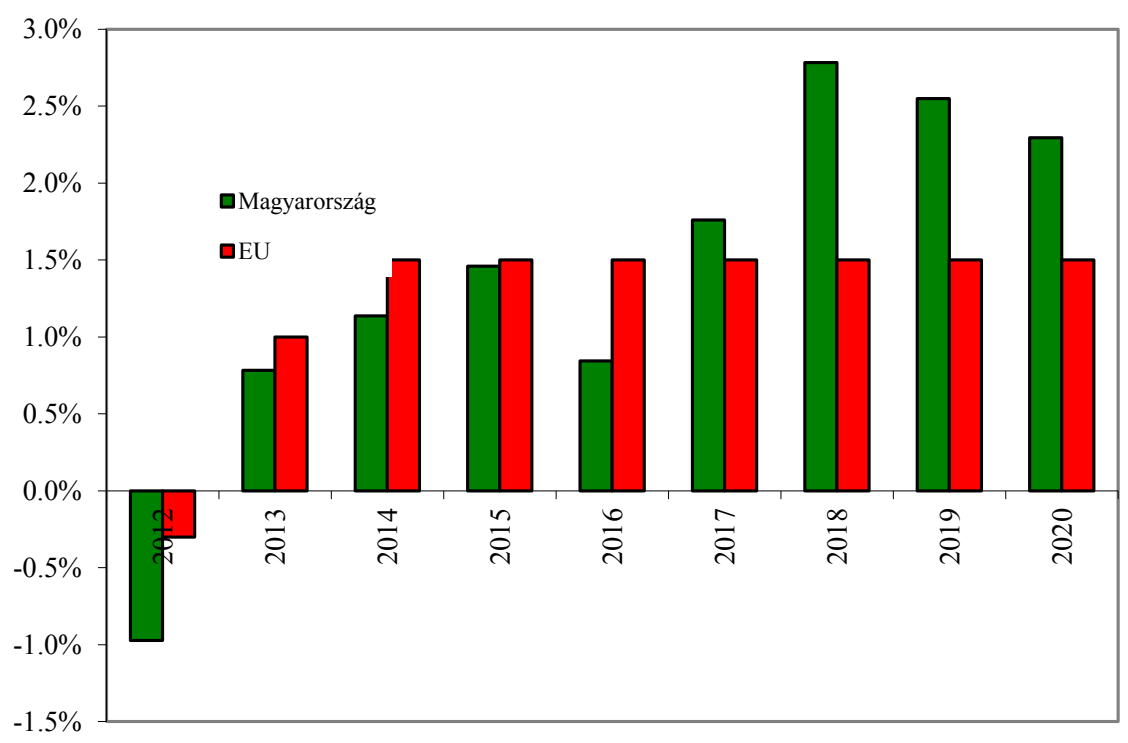

Fogyasztás

A lakossági fogyasztás 2000 és 2006 között folyamatosan növekedett, sőt az említett időszak második felében olyan mértékben haladta meg a GDP növekedési ütemét, hogy a növekedés letért a fenntartható pályáról. A gazdaság motorjává a lakossági fogyasztás vált, szemben egy egészséges szerkezetü növekedéssel, melyben a fö húzóeröt a beruházások és az export jelentik. Ez a jelenség az egyensúlyi mutatók (folyó fizetési mérleg) romlását okozta, a lakossági megtakarítás erősen mérséklődött, a nemzetgazdaság külföldi adósságállománya növekedett.

Ezt követően a lakossági fogyasztás növekedési üteme jelentősen mérséklődött, ezáltal visszakorrigált a fenntartható szintre, amit megerősített a válság időszakában tapasztalt visszaesés, valamint az ebből következett erőteljes alkalmazkodási folyamat. 2013-tól a lakossági fogyasztás mérsékelt emelkedése prognosztizálható, a növekedés üteme azonban tartósan elmaradhat a GDP-étől. A 2014 utáni időszakban modellszámításaimban figyelembe 
vettem egy esetleges enyhe fiskális lazítás lehetőségét is, melynek következtében a lakossági fogyasztás közelebb kerülhet a GDP növekedési üteméhez, de jellemzően így is 1-2 százalék közötti növekedési trendet követ 2020-ig.

A közösségi fogyasztás a tavalyi visszaesést követően 2013-ban már enyhén növekedhet, 2015-ben azonban megint csökkenhet a költségvetési politika választási évekhez köthető ciklikussága miatt. A közösségi fogyasztás dinamikája várhatóan ezt követően sem éri el az 1 százalékot, a fiskális politika nagy eséllyel restriktív marad a teljes vizsgált időszakban.

\section{Felhalmozás}

A bruttó állóeszköz-felhalmozás az eddig nyilvánosságra került adatok alapján 2012-ben is jelentősen visszaesett, 2013-ban viszont modellszámításaim szerint lassan újból emelkedésnek indulhat, amennyiben az exportorientált vállalatok kapacitásaik bővítése mellett döntenek. Eddig ugyanis inkább az óvatossági motívum dominált, a szereplök többsége ameddig csak lehetett, kivárt a beruházások megindításával, tekintettel a külső piacokkal valamint a hazai gazdaságpolitikával kapcsolatos bizonytalanságokra. A kilábalást segítgeti, hogy a vállalati beruházások sokévi visszaesést követően olyan mélypontot értek el 2012-ben, ahonnan szinte már csak felfelé vezethet az út. A bruttó állóeszköz-felhalmozás növekedési üteme erősen ingadozhat a teljes vizsgált időszakban, ami az állami beruházások hullámzásának és a különböző gazdasági ágazatok időben eltérő konjunktúrájának köszönhető.

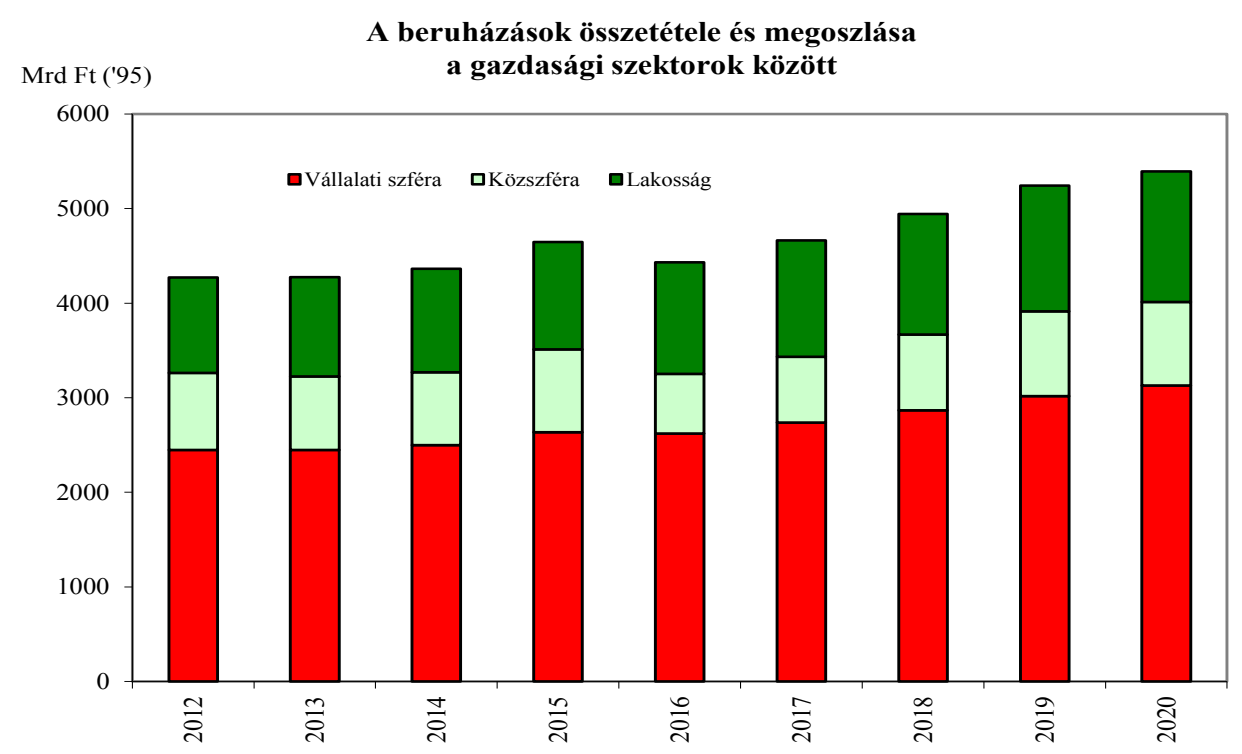




\section{A külkereskedelem alakulása}

Az export 2009-es visszaesése után 2010-2011-ben gyors helyreállási periódust tapasztalhattunk meg, amit 2012-ben jelentősen mérséklődő dinamika követett. A következő években mérsékelt, de hosszútávon kiegyensúlyozott export-növekedési ütemmel számolhatunk. Átlagban 6-8 százalék közé várható a növekedési ütem.

Az elmúlt néhány év lényeges fejleménye, hogy az import növekedési üteme szinte folyamatosan elmaradt az exportétól, így a külkereskedelmi egyenlegünk szufficitessé vált. Hosszabb távon arra számíthatunk, hogy az export és az import dinamikája kiegyenlítődik, a külkereskedelmi mérleg többlete azonban tartósan fennmarad.

\section{Az export és import alakulása a GDP százalékában}

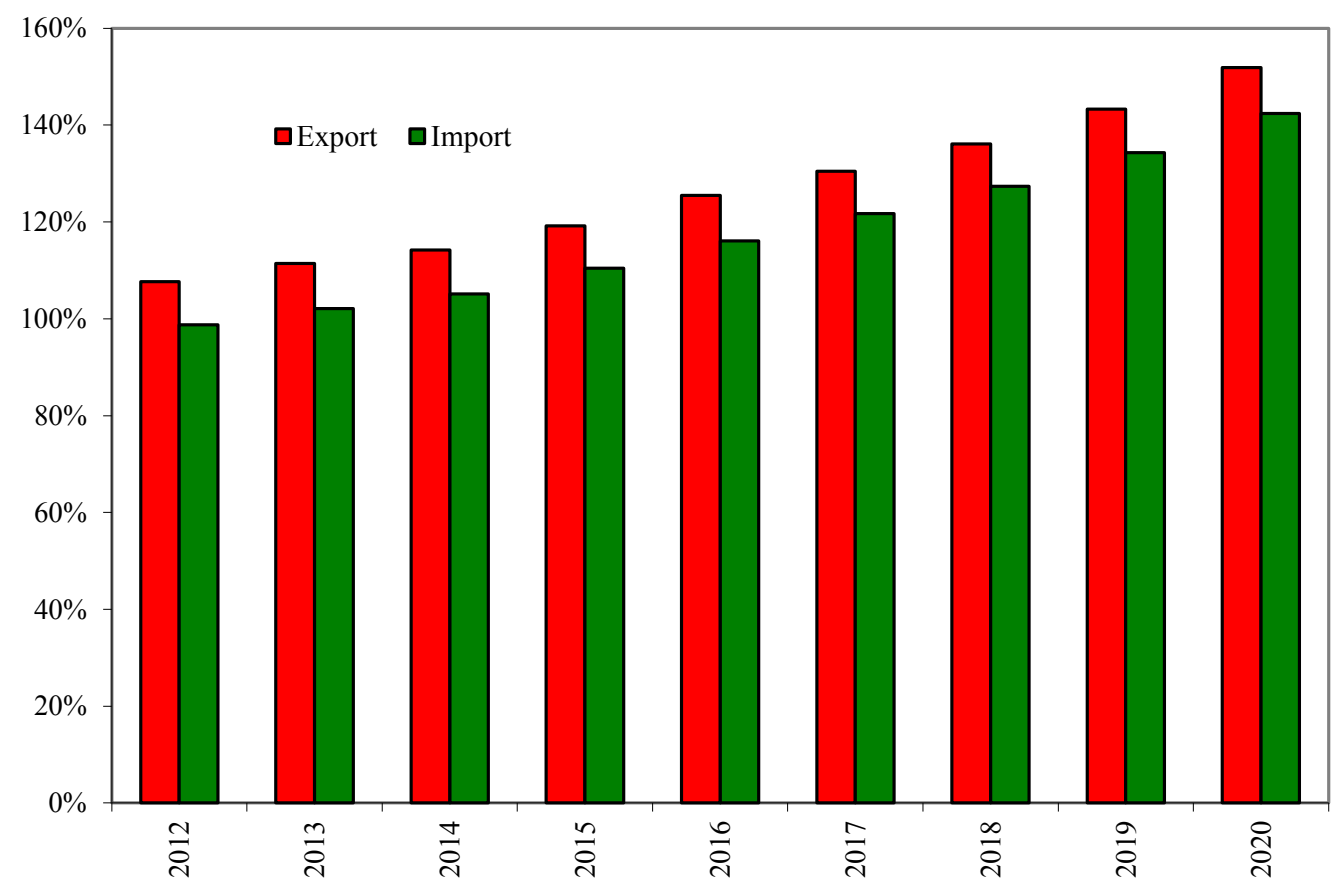


A magyar export és a külső kereslet alakulása

(százalékos változás az elöző évhez képest)

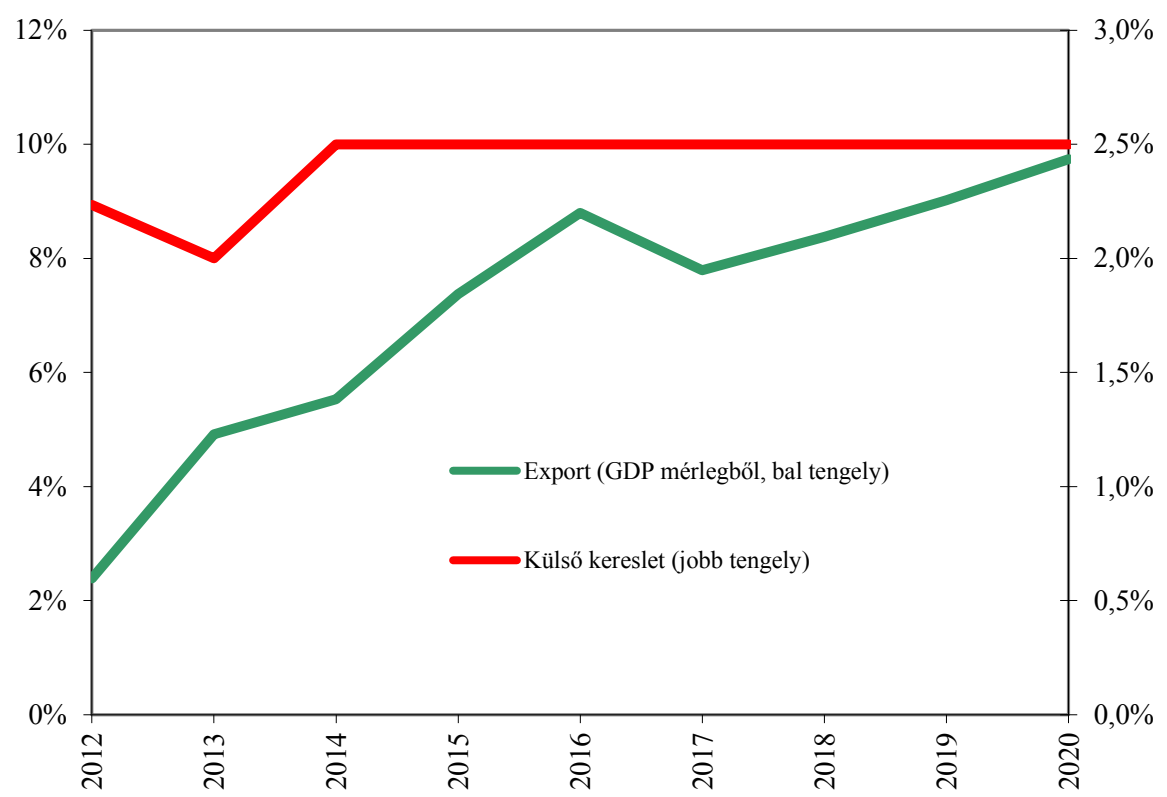

Az infláció alakulása

Az infláció alakulásában az utóbbi években egyre nagyobb a kormányzati intézkedések szerepe. 2012-ben jelentősen gyorsult a fogyasztói árindex növekedésének üteme, amelyet nagyrészt a közvetett adók növelése indukált. 2013-ban éppen ellentétes folyamatokra lehet számítani a szabályozott árak tervbe vett csökkentésének köszönhetően 4,5 százalék közelébe csökkenhet az inflációs ráta.

A következő években, a külső becsléseket is figyelembe véve, moderált import árindexszel számolunk, ami nagyrészt a nemzetközi nyersanyagpiac alakulásának függvénye. Modellszámításaim 2015-től 3 százalék körül ingadozó inflációs rátát jeleznek elöre, enyhén csökkenő trenddel. 
Az infláció alakulása

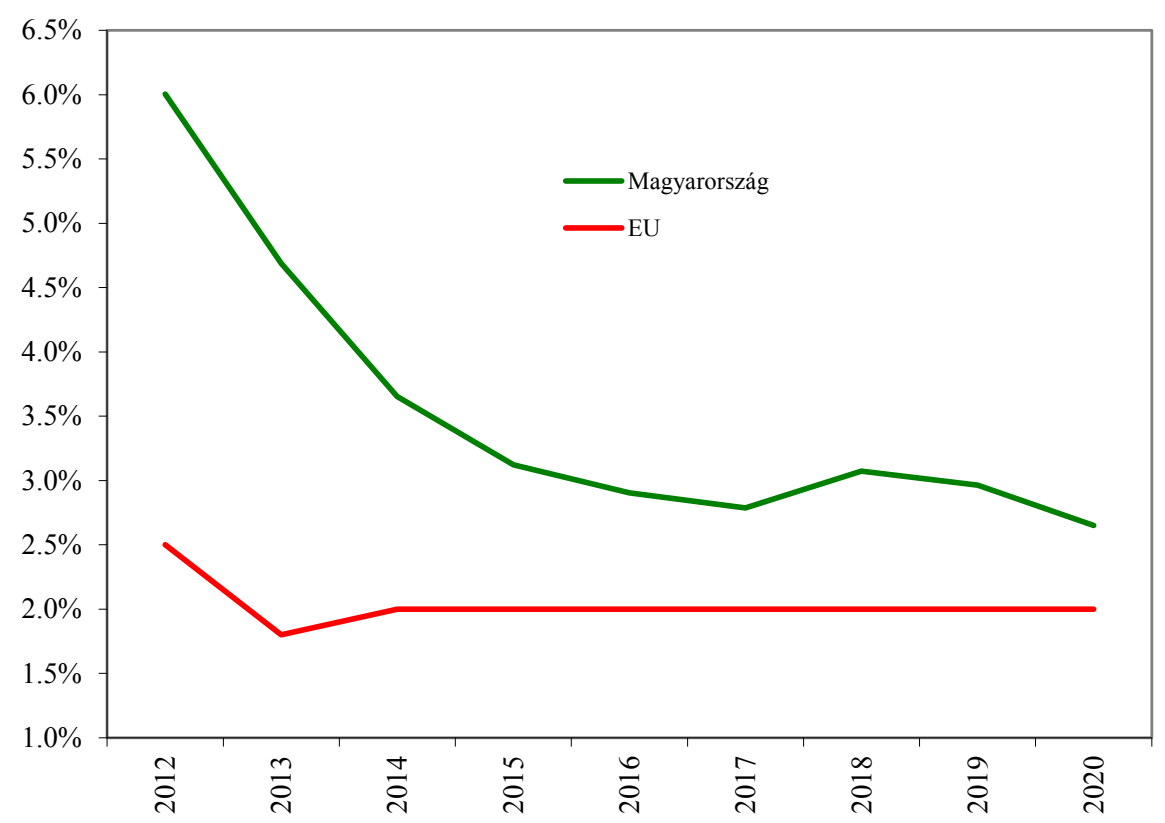

A bérek és keresetek alakulása

Az 2000-es évek első felében tapasztalt gyors reálbér-növekedés a fiskális kiigazítások és a válság hatására megtört, ami része volt az egyensúlyi makropályához történő visszatérési folyamatnak. Ennek következtében a keresetek vásárlóereje 2010-ben csak a 2005-ös szintet érte el. Feltételezésem szerint - amennyiben a következő években nem tapasztalható egzogén bérsokk - a reálbérek növekedési üteme nagyjából megegyezik majd a munka termelékenységének növekedésével, így csak igen mérsékelt ütemű felzárkózás képzelhető el a fejlett EU-tagállamok bérszintjéhez viszonyítva, és az is jelentős részben a az EU átlagánál magasabb hazai inflációból adódó nominális konvergenciának köszönhető. 
10. sz. ábra

Bér és átlagkereset növekedés

Magyarországon és az EU-ban

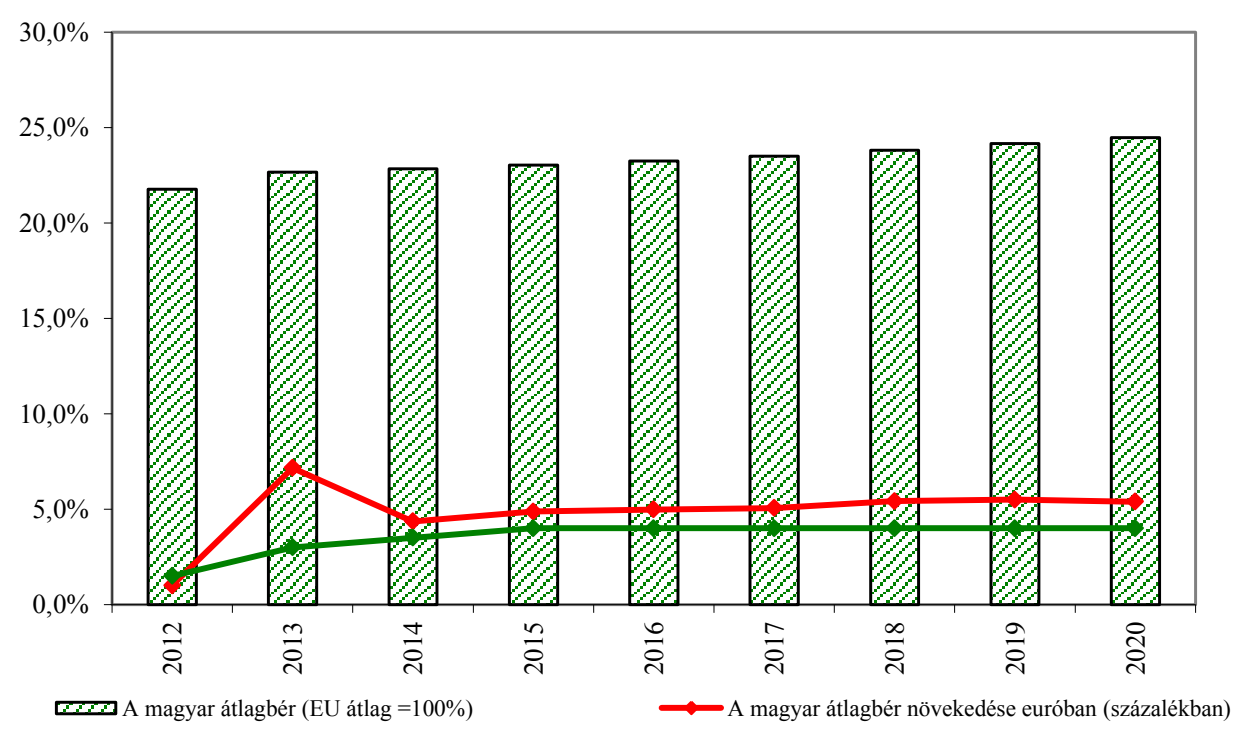

—Az EU átlagbér növekesése, százalékban

A lassan emelkedő aktivitási ráta mellett a foglalkoztatottak száma évente néhány tízezer fővel növekedhet. Összességében tehát fokozatos javulás várható a munkaerő-piacon, a munkanélküliségi ráta az időszak végére 7 százalék közelébe csökkenhet.

11. sz. ábra

Munkaerőpiaci helyzet

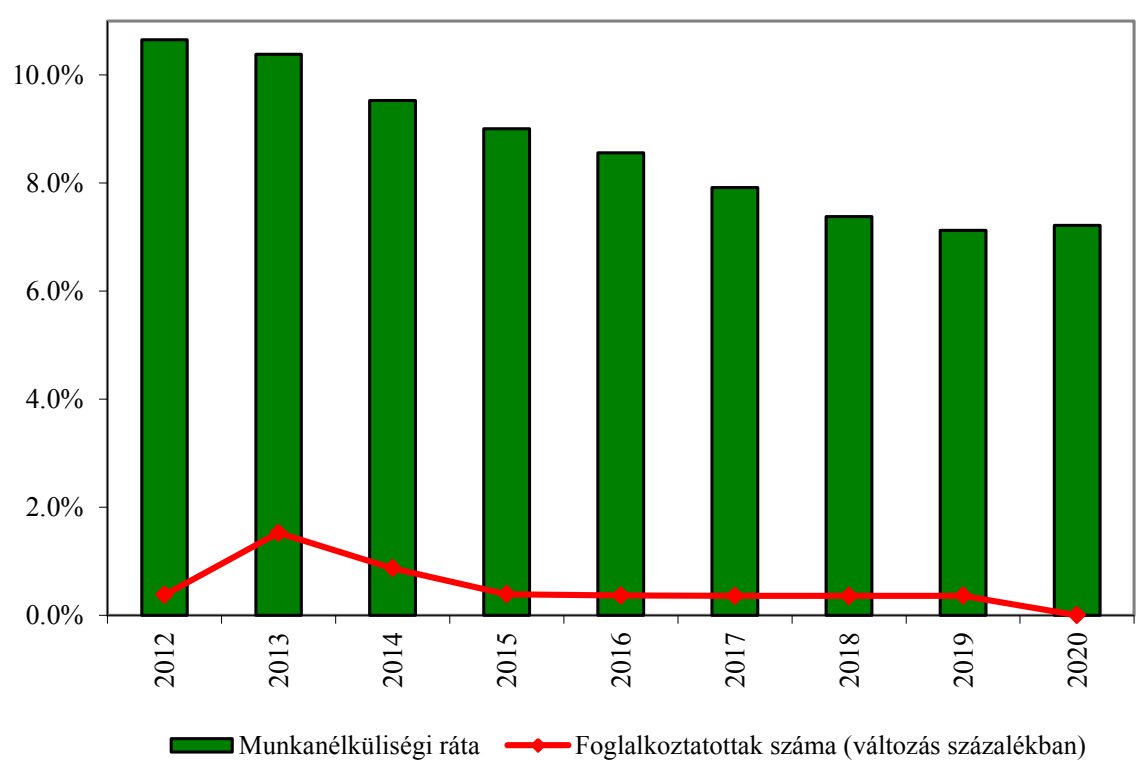


A háztartási szektor jövedelme 2006-ig jelentős növekedést mutatott, ami elsősorban a kormányzat expanzív bérpolitikájának volt köszönhető. Ezzel párhuzamosan a szektor nettó hitelpozíciója jelentősen romlott, ugyanis ebben az időszakban ugrottak meg a lakosság fogyasztási és ingatlanhitelei. Ezt követően 2008-ig lényegében stagnált a háztartások reáljövedelme, a hitelfelvétel azonban fokozódott, így a nettó hitelpozíció tovább romlott. 2008-tól a válság következtében meredeken csökkent a háztartási szektor jövedelme, ami óvatosabb viselkedésre ösztönözte a lakosságot. Így jelentősen csökkent a háztartások eladósodása, és érezhetően javult a szektor nettó hitelpozíciója.

A modell alapváltozatában azzal a feltételezéssel éltem, hogy a lakosság jövedelmének legnagyobb részét kitevő bérek csak kiegyensúlyozott mértékben növekednek 2020-ig. Így a szektor rendelkezésre álló jövedelme is viszonylag mérsékelt növekedést mutat majd, ám a lassan bővülő GDP-hez viszonyított aránya valamelyest növekedhet a következő években.

12. sz. ábra

\section{A lakossági jövedelmek alakulása}

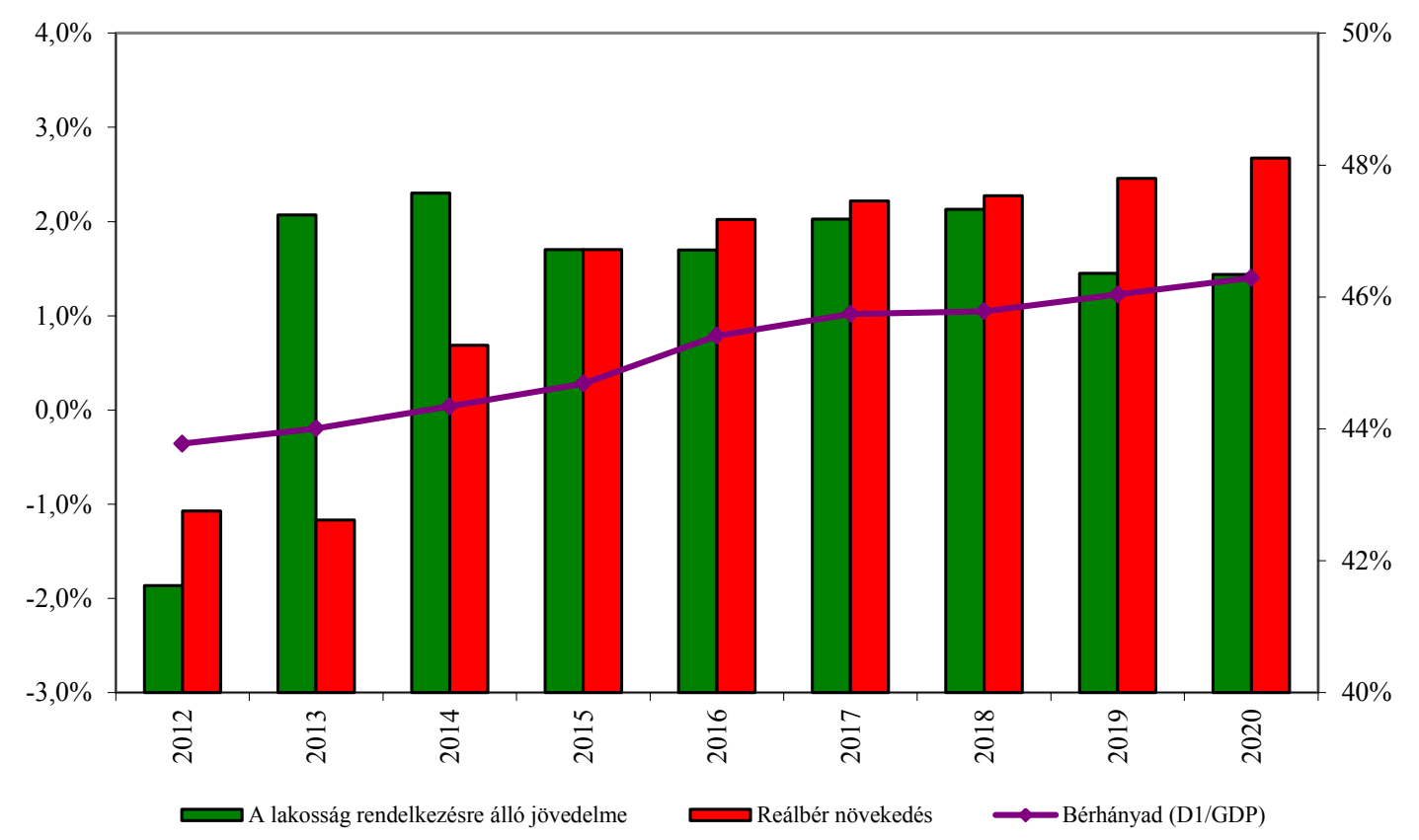


2002-ben megtört az államháztartás hiányának addig fokozatosan csökkenő trendje. 2006-ig folyamatosan nőtt a deficit, megközelítve a GDP 10 százalékát. A 2006-2007-es kiigazítás jelentős fordulatot hozott, és a csökkenő tendencia - köszönhetően a magas államadósságból adódó piaci kényszereknek - a válság éveiben is fennmaradt.

Az államháztartási hiány alakulásának szempontjából a legfőbb támpontot a Stabilitási és Növekedési Paktum nyújtja. Ennek értelmében a hiány már idén sem lehet 3 százaléknál magasabb. A következő években ráadásul a deficitnek fokozatosan csökkennie kell. A számítások során azt valószínüsítettem, hogy a következő időszakban mind az államháztartási bevételek, mind a kiadások GDP-hez viszonyított aránya a mérséklődik majd.

13. sz. ábra

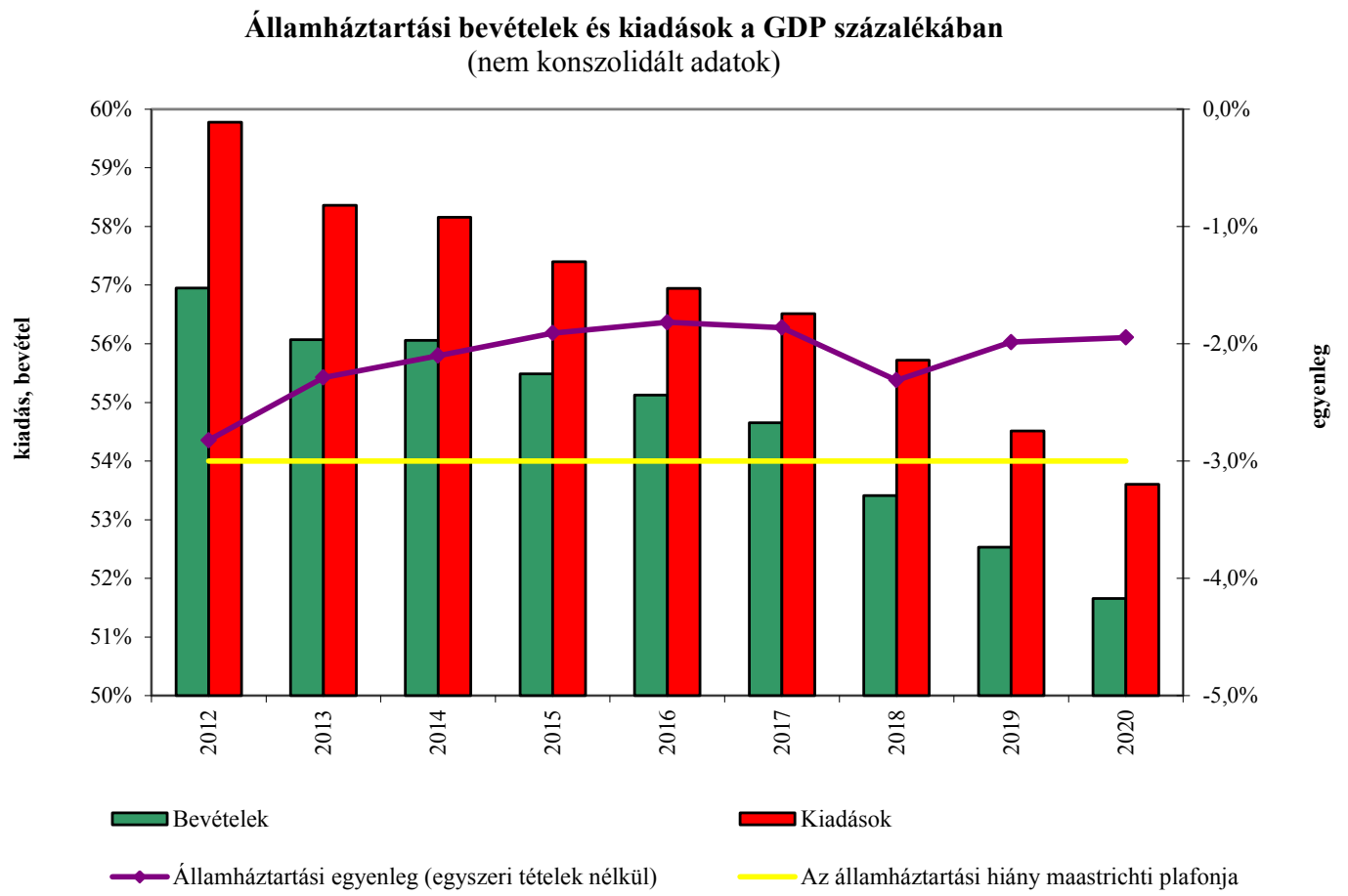

Az adósságállomány GDP-hez viszonyított aránya feltehetően 2011-ben érte el a maximumát, 2012-ben nagy valószínüséggel mérséklődött valamelyest, és a következő években is fokozatos csökkenés várható. A kedvező folyamatok ellenére a jelenlegi tendenciák alapján 2020-ig nem várható, hogy az adósságállomány a GDP 60 százaléka alá csökkenjen. 


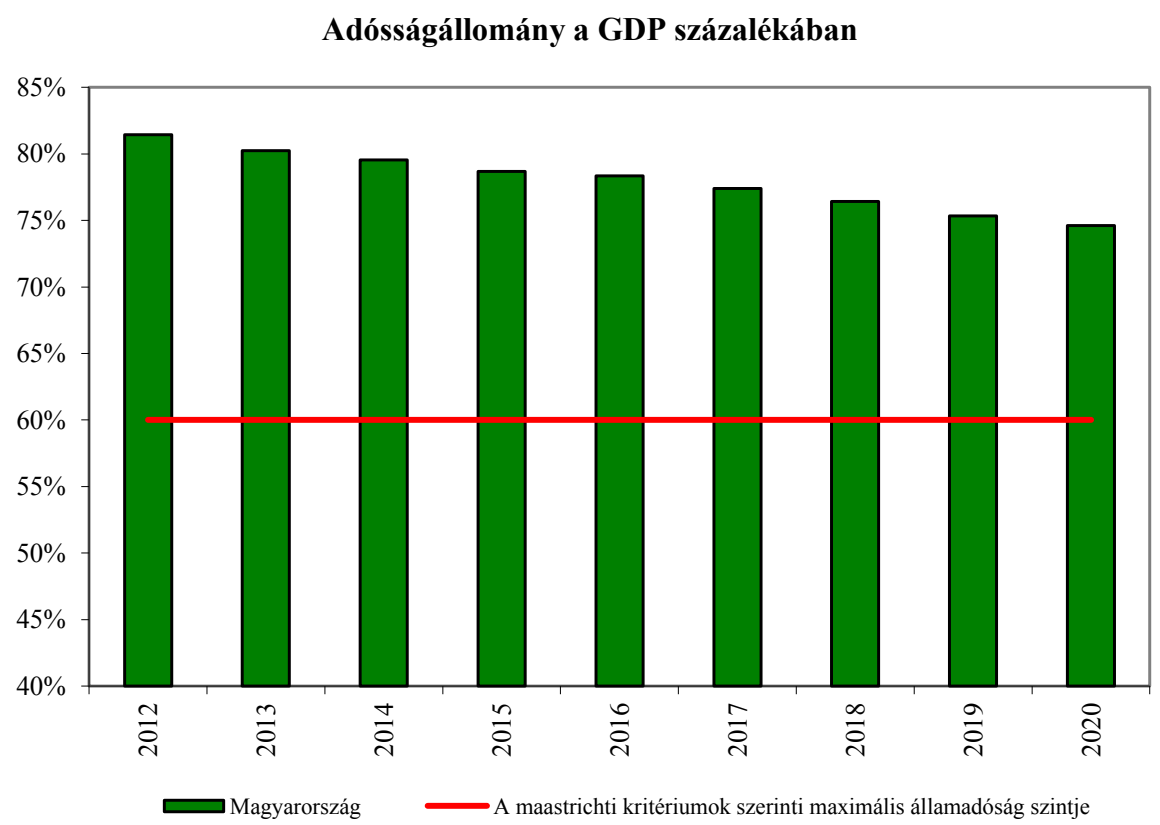

A folyó fizetési mérleg alakulása

Amennyiben a jelenlegi tendenciák folytatódnak, a következő években fokozatosan javul majd a folyó fizetési mérleg egyenlege, és a vizsgált időszak végére a többlet elérheti a GDP 4 százalékát. Erről a pályáról csak abban az esetben térhetne le a magyar gazdaság, ha egy markáns gazdasági fordulatot követően a lakosság ismét bátrabban kezdene költekezni, és így csökkenne a nettó megtakarítása. Ennek jelei azonban egyelőre nem látszanak.

Folyó fizetési mérleg

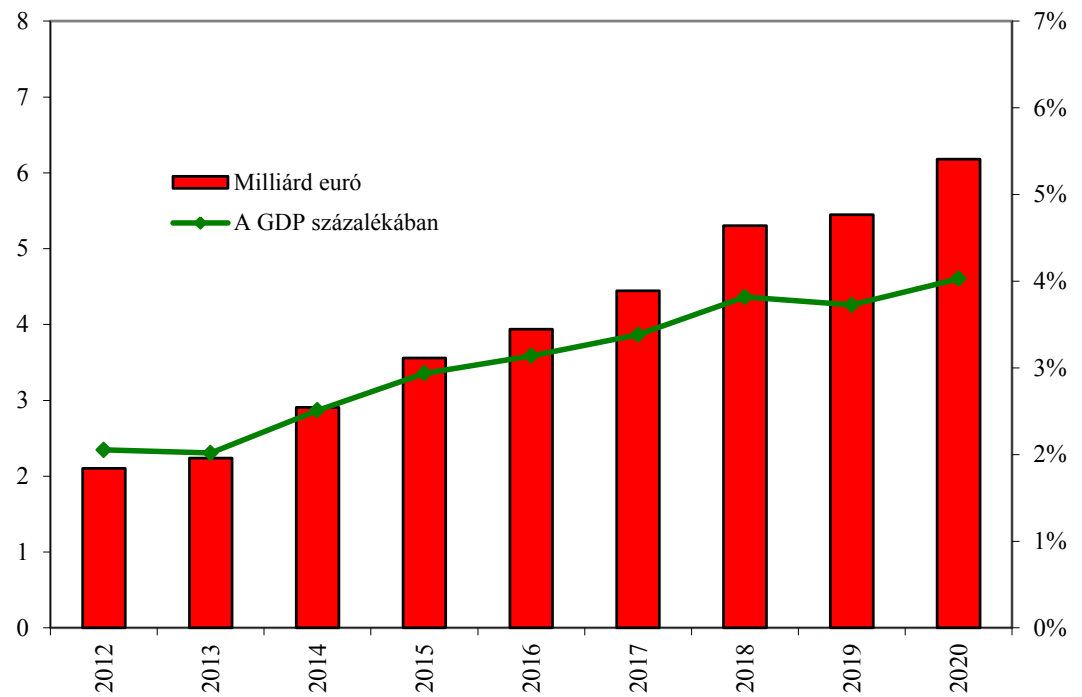


A makrogazdasági pályát összességében tekintve elmondható, hogy a 2009. évi visszaesést követően a magyar gazdaság lassú növekedésnek indult, ám a 2012-ban újabb recesszióba süllyedt. Idén 1 százalék alatti bővülés valószínüsíthető, és csak 2018-tól lehet arra számítani, hogy 2 százalék fölé gyorsul a növekedés. Azt is megvizsgáltuk, hogy az egy före jutó bruttó hazai termék szintjét tekintve mennyire sikerül felzárkóznunk 2020-ig az EU27 átlagos szintjéhez vásárlóerő-paritáson mérve. Látható, hogy az időszak elején a hazai mutató 65 százalék körüli szinten áll, és egy szük évtized alatt várhatóan alig 2 százalékponttal sikerül majd feljebb jutnunk.

\section{3. sz. táblázat}

\section{A fôbb makrogazdasági változók alakulása 2012-2020}

(alapváltozat)

\begin{tabular}{|l|c|c|c|c|c|c|c|c|c|}
\hline \multicolumn{1}{|c|}{ Mutatók } & $\mathbf{2 0 1 2}$ & $\mathbf{2 0 1 3}$ & $\mathbf{2 0 1 4}$ & $\mathbf{2 0 1 5}$ & $\mathbf{2 0 1 6}$ & $\mathbf{2 0 1 7}$ & $\mathbf{2 0 1 8}$ & $\mathbf{2 0 1 9}$ & $\mathbf{2 0 2 0}$ \\
\hline Bruttó hazai termék (GDP) & $-1.0 \%$ & $0.8 \%$ & $1.1 \%$ & $1.5 \%$ & $0.8 \%$ & $1.8 \%$ & $2.8 \%$ & $2.5 \%$ & $2.3 \%$ \\
Végsó fogyasztás & $-1.3 \%$ & $0.3 \%$ & $1.0 \%$ & $0.4 \%$ & $1.2 \%$ & $1.5 \%$ & $1.7 \%$ & $1.0 \%$ & $1.1 \%$ \\
$\quad$ Lakossági fogyasztás & $-1.3 \%$ & $0.3 \%$ & $1.1 \%$ & $0.7 \%$ & $1.3 \%$ & $1.7 \%$ & $1.9 \%$ & $1.2 \%$ & $1.3 \%$ \\
$\quad$ Közösségi fogyasztás & $-0.8 \%$ & $0.4 \%$ & $0.5 \%$ & $-1.0 \%$ & $0.0 \%$ & $0.5 \%$ & $1.0 \%$ & $-0.5 \%$ & $0.0 \%$ \\
Bruttó állóeszköz-felhalmoźs & $-4.7 \%$ & $0.7 \%$ & $2.4 \%$ & $4.2 \%$ & $3.4 \%$ & $3.7 \%$ & $3.5 \%$ & $4.3 \%$ & $4.1 \%$ \\
Bruttó felhalmozás & $-2.3 \%$ & $0.0 \%$ & $2.0 \%$ & $6.5 \%$ & $-4.8 \%$ & $5.2 \%$ & $6.1 \%$ & $6.1 \%$ & $2.9 \%$ \\
Belföldi felhasználás & $-1.5 \%$ & $0.3 \%$ & $1.2 \%$ & $1.7 \%$ & $-0.2 \%$ & $2.3 \%$ & $2.7 \%$ & $2.1 \%$ & $1.5 \%$ \\
Export & $2.4 \%$ & $4.9 \%$ & $5.5 \%$ & $7.4 \%$ & $8.8 \%$ & $7.8 \%$ & $8.4 \%$ & $9.0 \%$ & $9.7 \%$ \\
Import & $3.2 \%$ & $4.8 \%$ & $6.0 \%$ & $8.0 \%$ & $8.6 \%$ & $8.8 \%$ & $8.5 \%$ & $9.1 \%$ & $9.8 \%$ \\
Bruttó nemzeti jövedelem (GNI) & $-1.8 \%$ & $-0.1 \%$ & $0.8 \%$ & $1.3 \%$ & $0.8 \%$ & $1.9 \%$ & $2.6 \%$ & $2.3 \%$ & $2.1 \%$ \\
Rendelkezésre áló jövedelem (QDI) & $-1.9 \%$ & $2.1 \%$ & $2.3 \%$ & $1.7 \%$ & $1.7 \%$ & $2.0 \%$ & $2.1 \%$ & $1.5 \%$ & $1.4 \%$ \\
GDP (ppp-n, EU27=100) & $65.6 \%$ & $65.4 \%$ & $65.2 \%$ & $65.2 \%$ & $64.7 \%$ & $64.9 \%$ & $65.7 \%$ & $66.4 \%$ & $66.9 \%$ \\
QDI (ppp-n, EU27=100) & $48.8 \%$ & $49.3 \%$ & $49.9 \%$ & $50.3 \%$ & $50.6 \%$ & $51.1 \%$ & $51.7 \%$ & $51.9 \%$ & $52.2 \%$ \\
Infláció & $6.0 \%$ & $4.7 \%$ & $3.7 \%$ & $3.1 \%$ & $2.9 \%$ & $2.8 \%$ & $3.1 \%$ & $3.0 \%$ & $2.7 \%$ \\
A folyó fizetési mérleg egyenlege a GDP százalékában & $2.1 \%$ & $2.0 \%$ & $2.5 \%$ & $2.9 \%$ & $3.1 \%$ & $3.4 \%$ & $3.8 \%$ & $3.7 \%$ & $4.0 \%$ \\
Államháztartási egyenleg ESA elszámolásban & $-2.8 \%$ & $-2.3 \%$ & $-2.1 \%$ & $-1.9 \%$ & $-1.8 \%$ & $-1.9 \%$ & $-2.3 \%$ & $-2.0 \%$ & $-1.9 \%$ \\
Nominál átlagkereset & $4.9 \%$ & $3.5 \%$ & $4.4 \%$ & $4.9 \%$ & $5.0 \%$ & $5.0 \%$ & $5.4 \%$ & $5.5 \%$ & $5.4 \%$ \\
EU-transzferek & 3500 & 3500 & 3252 & 3630 & 2008 & 2260 & 2890 & 3520 & 3520 \\
\hline
\end{tabular}

A felzárkózási folyamatnak csak az egyik - bár kétségkívül igen fontos - eleme az egy före jutó GDP, legalább ennyire lényeges azonban az is, hogy a lakossági jövedelmek szintje is közelítsen a fejlett országok átlagához. A lakosság rendelkezésre álló jövedelmének alakulását vizsgálva azt tapasztaltam, hogy a vásárlóerő-paritáson számított mutató valamivel gyorsabb 
ütemben konvergál az EU27 átlagához, mint az egy före jutó GDP: a 2012-re becsült 48,8 százalék 2020-ra várhatóan 52,2 százalékra emelkedik.

A bruttó állóeszköz-felhalmozás több éven át tartó visszaesést követően 2013-tól lassan növekedni kezd, majd 2015-től valamivel gyorsabb ütemben bővül. Ebben jelentős szerepe van az EU-transzfereknek, melyekböl egyre többet sikerül lehívni a rendelkezésre álló keretből, így 2014-15-ben lehetséges a támogatások legnagyobb mértékű felhasználása, ami a közösségi beruházásokat nagymértékben bővíti. Ezt követően az állóeszköz-felhalmozás bővülése valamivel kisebb lesz, és 2016-tól kezdődően 3-4 százalék körül stabilizálódik a vizsgált időszak végéig. A közösségi beruházások mérsékelten növekednek, és jelentős ingadozásokat mutatnak a 2020-ig terjedő időszakban. A vállalati szektor beruházásai az EUtranszferek beérkezésének hatására megemelkedhetnek, majd ez a bővülés fokozatosan egyre kisebb lesz, végül az utolsó öt évben 4 százalék körüli, kiegyenlített növekedés következhet be.

\subsection{A „hatékonyabb kiadási szerkezet” szcenárió feltételrendszere és eredményei}

Ebben a változatban azt tételeztem fel, hogy a felhasznált EU-transzfereket hatékonyabb szerkezetben költjük el. Ez azt jelenti, hogy nagyobb arányban részesülnek a hosszú távú növekedést segítő tételek (például humántőke-beruházások), míg a kevésbé növekedésbarát tételek (például jövedelemtranszferek) súlya csökken. Ennek megfelelően az alábbi feltételeket változtattuk meg az alapváltozathoz képest.

- A Magyarország számára elvben elérhető 25,3 Mrd euró értékü támogatási keret 70 százalékát sikerül felhasználni 2007 és 2013 között, akárcsak az alapváltozatban.

- Az ezt követő évek során érkező transzferek értéke fokozatosan csökken, a felhasznált mennyiség megegyezik az alapváltozatban szereplő összegekkel.

- A beérkező transzferek felhasználási területei közti megoszlás nem változik: az alapok 63 százalékát továbbra is infrastrukturális beruházásokra, 17 százalékát humántőkeberuházásokra, 20 százalékát pedig termelő vállalatoknak nyújtott támogatásokra fordítják. 
- A kormányzati kiadások EU-transzferekhez kapcsolható részeinek funkcionális szerkezete kismértékben megváltozik: nagyobb súlyt kapnak azok a tételek, amelyek jelentős szerepet játszanak a TFP növekedésében, és így a felzárkózásban. Ezek elsősorban a $\mathrm{K}+\mathrm{F}$ kiadások és a humántőke-beruházások. Kevesebbet költ viszont az állam a gazdasági növekedés szempontjából kevésbé produktív tételekre, mint például jövedelempótló támogatásokra.

A modellfuttatások alapján a feltételek fent említett megváltoztatása következtében 2011-től kezdve évente átlagosan mintegy 0,1 százalékponttal gyorsul a GDP növekedése. Ennek az a magyarázata, hogy feltételezéseink szerint a kormányzat a megnövekvő források nagyobb hányadát fordítja a kutatás-fejlesztés és a humántőke támogatására, ami kínálati oldalon keresztül javítja a hosszú távú növekedési lehetőségeket.

A lakossági és a közösségi fogyasztás növekedési ütemére csak minimális hatással vannak a megváltozott feltételek. Az infláció esetében szintén nincs számottevő különbség a két szcenárió között, 2013-tól kezdődően mindössze 0,01-0,02 százalékponttal magasabb az alapváltozatbeli értékeknél.

A versenyszférában megnövekvő munkaerő-kereslet következtében a munkanélküliségi ráta már a vizsgált időszak elejétől kezdődően valamivel alacsonyabban alakul, majd fokozatosan tovább csökken az alappályához képest. Azonban 2020-ra így is csak 0,1 százalékpontos különbség mutatkozik. 
A főbb makrogazdasági változók alakulása 2012-2020

(hatékonyabb kiadási szerkezet)

\begin{tabular}{|c|c|c|c|c|c|c|c|c|c|}
\hline Mutatók & 2012 & 2013 & 2014 & 2015 & 2016 & 2017 & 2018 & 2019 & 2020 \\
\hline Bruttó hazai termék (GDP) & $-1,0 \%$ & $0,8 \%$ & $1,2 \%$ & $1,5 \%$ & $0,9 \%$ & $1,8 \%$ & $2,9 \%$ & $2,7 \%$ & $2,3 \%$ \\
\hline Végső fogyasztás & $-1,3 \%$ & $0,3 \%$ & $1,0 \%$ & $0,5 \%$ & $1,2 \%$ & $1,5 \%$ & $1,8 \%$ & $1,0 \%$ & $1,1 \%$ \\
\hline Lakossági fogyasztás & $-1,3 \%$ & $0,3 \%$ & $1,1 \%$ & $0,7 \%$ & $1,4 \%$ & $1,7 \%$ & $1,9 \%$ & $1,2 \%$ & $1,3 \%$ \\
\hline Közösségi fogyasztás & $-0,8 \%$ & $0,4 \%$ & $0,5 \%$ & $-1,0 \%$ & $0,0 \%$ & $0,5 \%$ & $1,0 \%$ & $-0,5 \%$ & $0,0 \%$ \\
\hline Bruttó állóeszköz-felhalmozás & $-4,7 \%$ & $0,7 \%$ & $2,4 \%$ & $4,2 \%$ & $3,4 \%$ & $3,7 \%$ & $3,5 \%$ & $4,3 \%$ & $4,1 \%$ \\
\hline Bruttó felhalmozás & $-2,3 \%$ & $0,0 \%$ & $2,4 \%$ & $7,1 \%$ & $-4,1 \%$ & $5,6 \%$ & $6,9 \%$ & $6,7 \%$ & $2,7 \%$ \\
\hline Belföldi felhasználás & $-1,5 \%$ & $0,3 \%$ & $1,3 \%$ & $1,9 \%$ & $0,0 \%$ & $2,4 \%$ & $2,9 \%$ & $2,3 \%$ & $1,5 \%$ \\
\hline Export & $2,4 \%$ & $4,9 \%$ & $5,5 \%$ & $7,4 \%$ & $8,8 \%$ & $7,8 \%$ & $8,4 \%$ & $9,0 \%$ & $9,7 \%$ \\
\hline Import & $3,2 \%$ & $4,8 \%$ & $6,1 \%$ & $8,1 \%$ & $8,6 \%$ & $8,8 \%$ & $8,6 \%$ & $9,1 \%$ & $9,7 \%$ \\
\hline Bruttó nemzeti jövedelem (GNI) & $-1,8 \%$ & $-0,1 \%$ & $0,9 \%$ & $1,4 \%$ & $0,9 \%$ & $2,0 \%$ & $2,7 \%$ & $2,4 \%$ & $2,2 \%$ \\
\hline Rendelkezésre álló jövedelem (QDI) & $-1,9 \%$ & $2,1 \%$ & $2,3 \%$ & $1,7 \%$ & $1,7 \%$ & $2,1 \%$ & $2,2 \%$ & $1,5 \%$ & $1,5 \%$ \\
\hline GDP (ppp-n, EU27=100) & $65,6 \%$ & $65,4 \%$ & $65,2 \%$ & $65,2 \%$ & $64,9 \%$ & $65,1 \%$ & $66,0 \%$ & $66,8 \%$ & $67,3 \%$ \\
\hline QDI (ppp-n, EU27=100) & $48,8 \%$ & $49,3 \%$ & $49,9 \%$ & $50,3 \%$ & $50,6 \%$ & $51,2 \%$ & $51,8 \%$ & $52,0 \%$ & $52,3 \%$ \\
\hline Infláció & $6,0 \%$ & $4,7 \%$ & $3,7 \%$ & $3,1 \%$ & $2,9 \%$ & $2,8 \%$ & $3,1 \%$ & $3,0 \%$ & $2,7 \%$ \\
\hline A folyó fizetési mérleg egyenlege a GDP százalékában & $2,2 \%$ & $2,2 \%$ & $2,7 \%$ & $3,2 \%$ & $3,5 \%$ & $3,8 \%$ & $4,3 \%$ & $4,2 \%$ & $4,6 \%$ \\
\hline Államháztartási egyenleg ESA elszámolásban & $-2,8 \%$ & $-2,3 \%$ & $-2,1 \%$ & $-1,9 \%$ & $-1,8 \%$ & $-1,9 \%$ & $-2,3 \%$ & $-1,9 \%$ & $-1,8 \%$ \\
\hline Nominál átlagkereset & $4,9 \%$ & $3,5 \%$ & $4,4 \%$ & $4,9 \%$ & $5,0 \%$ & $5,1 \%$ & $5,4 \%$ & $5,5 \%$ & $5,4 \%$ \\
\hline EU-transzferek & 3500 & 3500 & 3252 & 3630 & 2008 & 2260 & 2890 & 3520 & 3520 \\
\hline
\end{tabular}

Az egyensúlyi mutatók közül a folyó fizetési mérleg egyenlege a teljes időszakban folyamatosan javul az alapszcenárióhoz képest. A 2020-ra 0,6 százalékpontosra becsült különbséget döntően a vállalati szféra nettó hitelpozíciójának javulása magyarázza.

Az államháztartás egyenlegét tekintve nem tapasztalható ekkora változás, a vizsgált időszak alatt végig 0,1 százalékpont alatt marad az alapváltozathoz viszonyított eltérés.

\subsection{A „kevesebb EU-forrás” szcenárió feltételrendszere és eredményei}

Ebben a változatban visszatértem az alapváltozatban szereplő államháztartási szerkezethez, de feltételeztem, hogy az abban szereplönél kevesebb EU-transzfert sikerül ténylegesen felhasználni. Ennek megfelelően az alábbi feltételeket változtattam meg az alapszcenárióhoz képest. 
- A Magyarország számára elvben elérhető 25,3 Mrd euró értékü támogatási keretnek mindössze 50 százalékát sikerül felhasználni a 2007 és 2013 közötti időszak során.

- Az ezt követő évek során érkező transzferek értéke fokozatosan csökken, és a felhasznált mennyiség nem éri el az alapváltozatban szereplö összegeket.

- A beérkező transzferek felhasználási területei közti megoszlás ezúttal is változatlan marad.

A modellfuttatások szerint a külső források csökkenése miatt a 2011 és 2020 közötti időszakban a GDP-bővülés átlagosan mintegy 0,1 százalékponttal lelassult. Ez azzal magyarázható, hogy az uniós forrásokból kevesebbet tudnak felhasználni, és bár az EUtranszferekhez nem köthető kormányzati kiadások megnövekednek a teljes időszak alatt, az nem képes kompenzálni az előbbi hatást, ezért összességében visszaveti a növekedést. A visszaesés azonban nem drámai mértékü, nagyjából megegyezik az előző változatban tapasztalt növekedéstöbblettel. Úgy tünik tehát, hogy az EU-források mennyiségének változása adott esetben épp akkora hatást gyakorolhat a hosszú távú fejlődésre, mint amikor ez szerkezeti változásokkal is együtt jár. Ezt e feltételezést megerősíti a makrogazdasági mutatók többségének alakulása, a lakossági és a közösségi fogyasztás növekedési üteme is nagyjából az előző szcenárióval ellentétes pályát ír le ebben az esetben.

Az infláció esetében nincs számottevő különbség, nagyon csekély elmaradás tapasztalható az alapváltozathoz képest. Bár ez az eltérés fokozatosan növekszik a vizsgált időszakban, mindvégig 0,02 százalékpont alatt marad. 
A főbb makrogazdasági változók alakulása 2010-2020 (alacsonyabb lehívási arány)

\begin{tabular}{|c|c|c|c|c|c|c|c|c|c|}
\hline Mutatók & 2012 & 2013 & 2014 & 2015 & 2016 & 2017 & 2018 & 2019 & 2020 \\
\hline Bruttó hazai termék (GDP) & $-1.0 \%$ & $0.8 \%$ & $1.1 \%$ & $1.4 \%$ & $0.7 \%$ & $1.7 \%$ & $2.6 \%$ & $2.4 \%$ & $2.3 \%$ \\
\hline Végső fogyasztás & $-1.3 \%$ & $0.3 \%$ & $1.0 \%$ & $0.4 \%$ & $1.1 \%$ & $1.5 \%$ & $1.7 \%$ & $0.9 \%$ & $1.1 \%$ \\
\hline Lakossági fogyasztás & $-1.3 \%$ & $0.3 \%$ & $1.1 \%$ & $0.7 \%$ & $1.3 \%$ & $1.7 \%$ & $1.8 \%$ & $1.2 \%$ & $1.3 \%$ \\
\hline Közösségi fogyasztás & $-0.8 \%$ & $0.4 \%$ & $0.5 \%$ & $-1.0 \%$ & $0.0 \%$ & $0.5 \%$ & $1.0 \%$ & $-0.5 \%$ & $0.0 \%$ \\
\hline Bruttó állóeszköz-felhalmozás & $-4.7 \%$ & $0.7 \%$ & $2.4 \%$ & $4.2 \%$ & $3.4 \%$ & $3.7 \%$ & $3.5 \%$ & $4.3 \%$ & $4.1 \%$ \\
\hline Bruttó felhalmozás & $-2.3 \%$ & $0.0 \%$ & $1.7 \%$ & $6.0 \%$ & $-5.4 \%$ & $4.8 \%$ & $5.3 \%$ & $5.4 \%$ & $3.0 \%$ \\
\hline Belföldi felhasználás & $-1.5 \%$ & $0.3 \%$ & $1.1 \%$ & $1.6 \%$ & $-0.3 \%$ & $2.2 \%$ & $2.5 \%$ & $1.9 \%$ & $1.5 \%$ \\
\hline Export & $2.4 \%$ & $4.9 \%$ & $5.5 \%$ & $7.4 \%$ & $8.8 \%$ & $7.8 \%$ & $8.4 \%$ & $9.0 \%$ & $9.8 \%$ \\
\hline Import & $3.2 \%$ & $4.8 \%$ & $6.0 \%$ & $8.0 \%$ & $8.6 \%$ & $8.8 \%$ & $8.5 \%$ & $9.1 \%$ & $9.8 \%$ \\
\hline Bruttó nemzeti jövedelem (GNI) & $-1.8 \%$ & $-0.1 \%$ & $0.8 \%$ & $1.3 \%$ & $0.7 \%$ & $1.8 \%$ & $2.5 \%$ & $2.2 \%$ & $2.1 \%$ \\
\hline Rendelkezésre álló jövedelem (QDI) & $-1.9 \%$ & $2.1 \%$ & $2.3 \%$ & $1.7 \%$ & $1.7 \%$ & $2.0 \%$ & $2.1 \%$ & $1.4 \%$ & $1.4 \%$ \\
\hline GDP (ppp-n, EU27=100) & $65.6 \%$ & $65.4 \%$ & $65.2 \%$ & $65.1 \%$ & $64.6 \%$ & $64.7 \%$ & $65.4 \%$ & $66.0 \%$ & $66.5 \%$ \\
\hline QDI (ppp-n, EU27=100) & $48.8 \%$ & $49.3 \%$ & $49.9 \%$ & $50.2 \%$ & $50.6 \%$ & $51.1 \%$ & $51.6 \%$ & $51.8 \%$ & $52.0 \%$ \\
\hline Infláció & $6.0 \%$ & $4.7 \%$ & $3.7 \%$ & $3.1 \%$ & $2.9 \%$ & $2.8 \%$ & $3.1 \%$ & $3.0 \%$ & $2.7 \%$ \\
\hline A folyó fizetési mérleg egyenlege a GDP százalékában & $1.4 \%$ & $1.3 \%$ & $1.8 \%$ & $2.2 \%$ & $2.5 \%$ & $2.8 \%$ & $3.2 \%$ & $3.1 \%$ & $3.4 \%$ \\
\hline Államháztartási egyenleg ESA elszámolásban & $-2.8 \%$ & $-2.3 \%$ & $-2.0 \%$ & $-1.8 \%$ & $-1.7 \%$ & $-1.7 \%$ & $-2.2 \%$ & $-1.8 \%$ & $-1.8 \%$ \\
\hline Nominál átlagkereset & $4.8 \%$ & $3.5 \%$ & $4.3 \%$ & $4.8 \%$ & $4.9 \%$ & $5.0 \%$ & $5.4 \%$ & $5.4 \%$ & $5.3 \%$ \\
\hline EU-transzferek & 3500 & 3500 & 3180 & 3450 & 1720 & 1900 & 2350 & 2800 & 2800 \\
\hline
\end{tabular}

Ebben a változatban a munkanélküliségi ráta emelkedik az alapszcenárióhoz képest, 2020-ban valamivel több, mint 0,1 százalékkal lesz magasabb az alapváltozathoz viszonyítva.

Az egyensúlyi mutatók közül a folyó fizetési mérleg GDP-arányos egyenlege rögtön az időszak kezdetén 5-6 tized százalékkal romlik a jelenlegi szcenárió esetén, és ez a különbség nagyjából fenn is marad egészen 2020-ig. Ez az egyenlegromlás döntően a vállalati szféra nettó hitelpozíciójának romlásából adódik, miközben a háztartási és kormányzati szektor esetében minimális javulás következett be.

Az államháztartás GDP-arányos egyenlegének alapváltozattól való eltérését szintén csekély elmozdulások jellemzik. A század-százalékpontokban kifejezhető romlást elsősorban az okozza, hogy a csökkenő EU-források egy részét az államháztartás pótolja, ami természetesen többletkiadásokat jelent. 


\subsection{A három szcenárió összehasonlitó elemzése}

Az előző három alfejezetben részletesen ismertetett változatok egybevetése során négy mutató alakulását emeljük ki. Ezek közül két indikátorral azért érdemes részletesebben foglalkozni, mert hosszú távú lefutásukban jelentősebb különbségeket tapasztalunk, kettővel pedig épp azért, mert minimális az egyes szcenáriók közötti eltérés, aminek viszont fontos üzenete van a gazdaságpolitikai döntéshozók felé.

A vásárlóerő-paritáson számított GDP idősora érzékelhetően eltér a három bemutatott változatban. A „hatékonyabb kiadási szerkezet” szcenárióban kapott kedvezőbb értékek azzal magyarázhatóak, hogy ebben a változatban az EU-transzferekhez köthető kiadási szerkezet hatékonyabban szolgálja a gazdasági felzárkózást. A „kevesebb külső forrás” verzióban épp annyi az elmaradás az alapváltozathoz képest, mint amennyi többlet a másik alternatív szcenárióban keletkezik.

16. sz. ábra

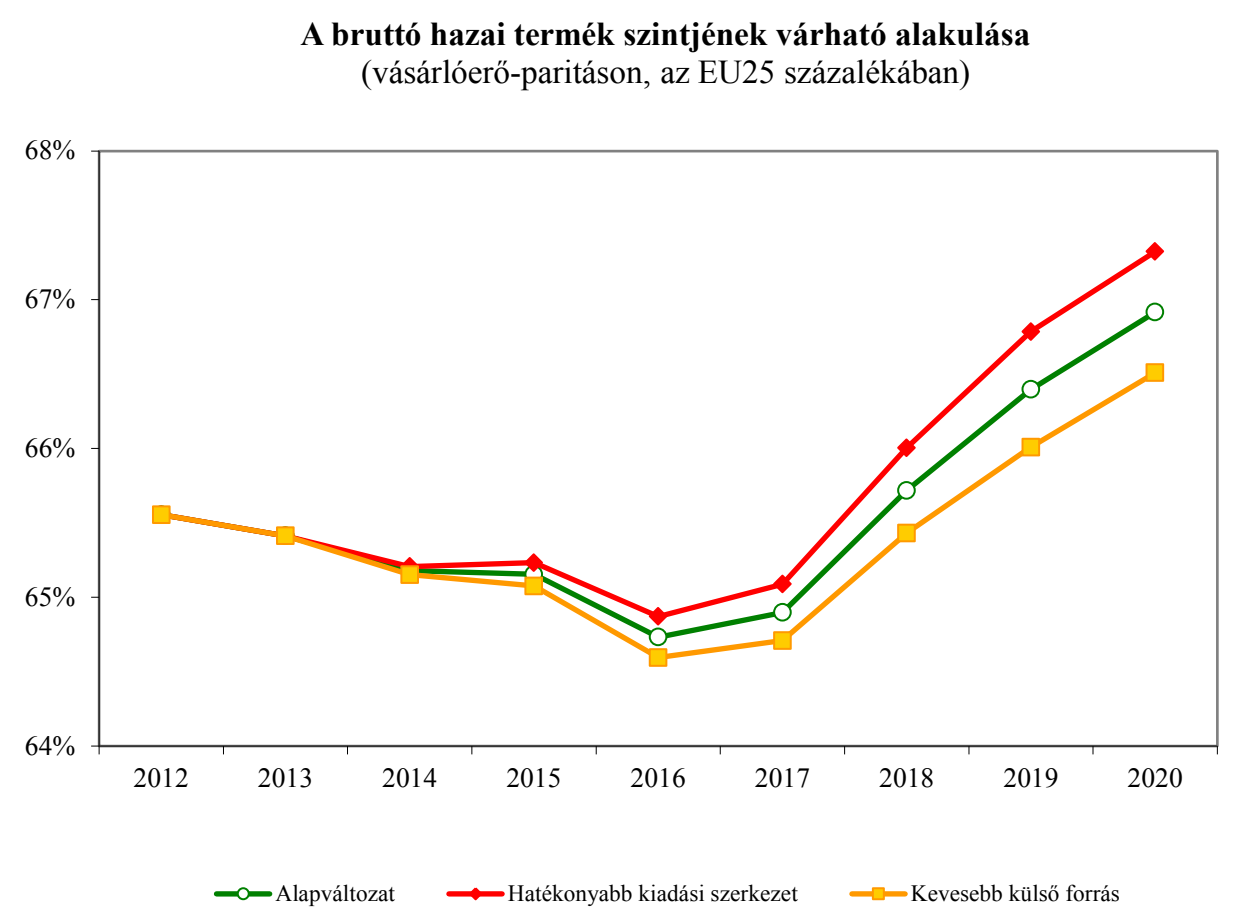

A lakosság rendelkezésre álló jövedelmében sokkal kisebb eltéréseket tapasztalunk, mint a GDP esetében. Ez az első látásra talán meglepő eredmény két tényezőre vezethető vissza. Az egyik, hogy a lakossági jövedelem nagyságát leginkább meghatározó bértömeg csak részben 
követi a bruttó hazai termék dinamikáját. Az első alternatív változatban például a kedvezőbb gazdasági környezetet (növekedést ösztönző fiskális politika, több EU forrás) a vállalatok elsősorban saját versenyképességük javulásaként érzékelik. Az ebből adódó hozzáadott-érték többletnek csak egy része növeli a bértömeget, a többi vállalkozási szféra jövedelmét gyarapítja. Ugyanez részben elmondható ellentétes előjellel a második alternatív változatról is. A két szcenárióban az alapváltozattól vett eltérés 2020-ig végig 0,2 százalékponton belül marad.

17. sz. ábra

A lakosság rendelkezésre álló jövedelmének várható alakulása

(vásárlóerö-paritáson, az EU25 százalékában)

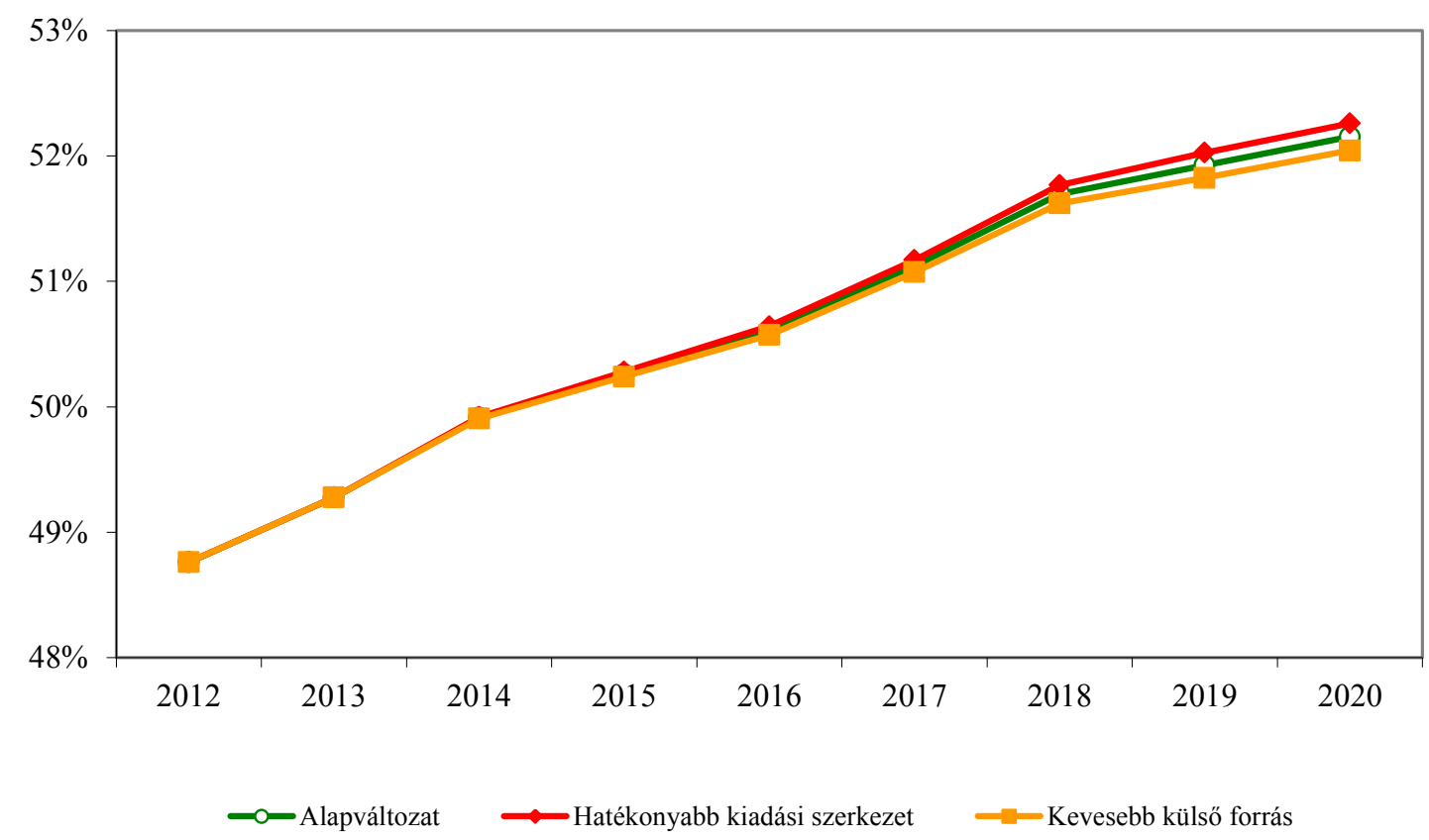

Az előzőekben azt láthattuk, hogy az alapváltozattól eltérő esetekben jelentkező jövedelemtöbblet, illetve jövedelemelmaradás nem kizárólag a háztartásoknál csapódik le. Ez azt jelenti, hogy a másik két tulajdonosi szektor is szerepet kap, vagyis a vállalatok és az állam. A következő ábra azt mutatja, hogy államháztartás egyenlege az alternatív szcenáriókban alig tér el az alapváltozattól. 
18. sz. ábra

Az államháztartás GDP-arányos egyenlegének várható alakulása

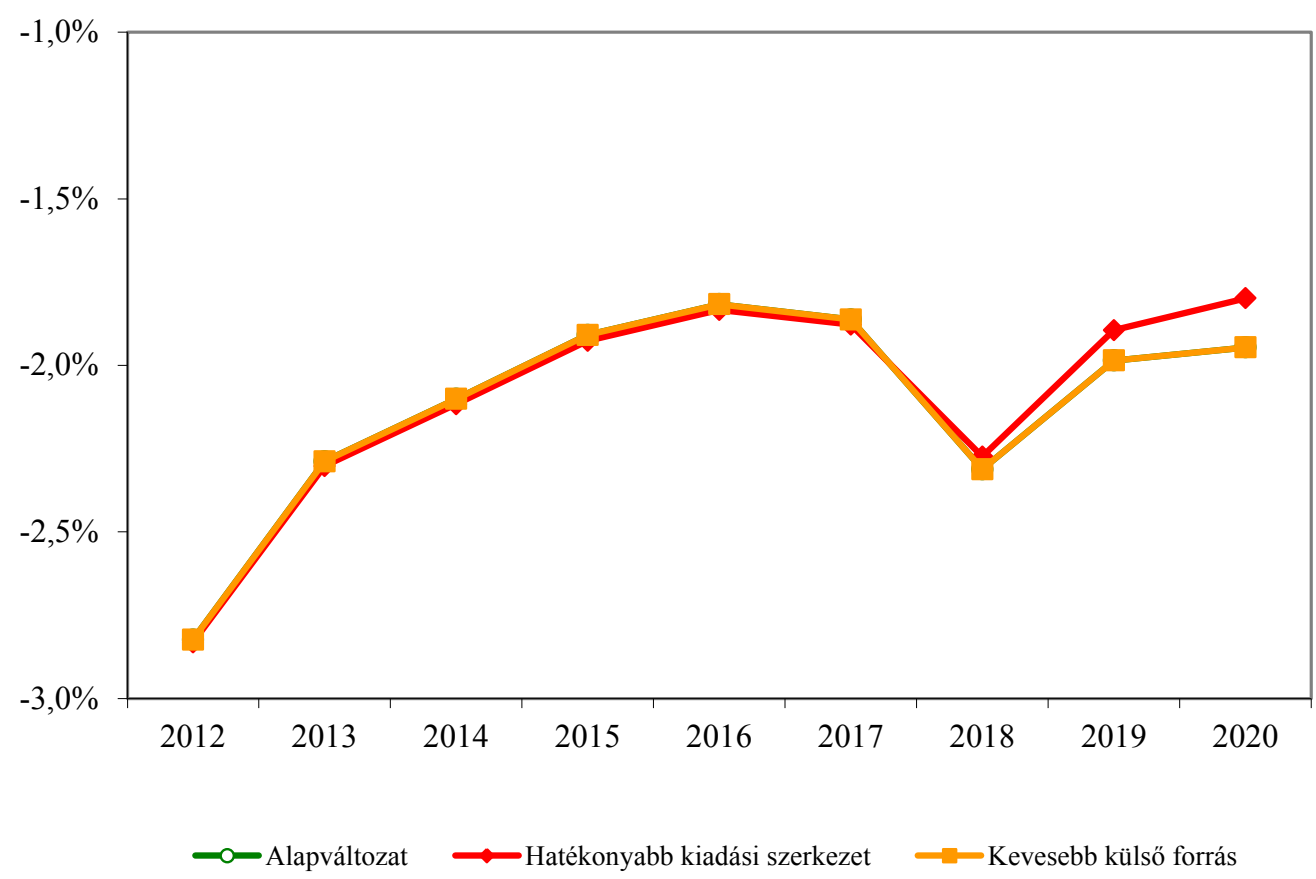

Érzékelhető különbség szinte csak az időszak végén mutatkozik, ekkor a „hatékonyabb kiadási szerkezet" szcenárióban valamivel kisebb a deficit, mint a másik kettőben. Mivel azonban ezek az eltérések is viszonylag csekélyek, valószínüsíthetö, hogy az alternatív esetekben az állam jövedelmi pozíciója sem tér el jelentősen az alapváltozatban szereplö értéktől. A jövedelemelosztás jellegéből adódóan ez nem jelenthet mást, mint azt, hogy a vállalkozásoknál maradó jövedelem változik a legerőteljesebben. 


\section{A folyó fizetési mérleg várható alakulása}

(a GDP százalékában)

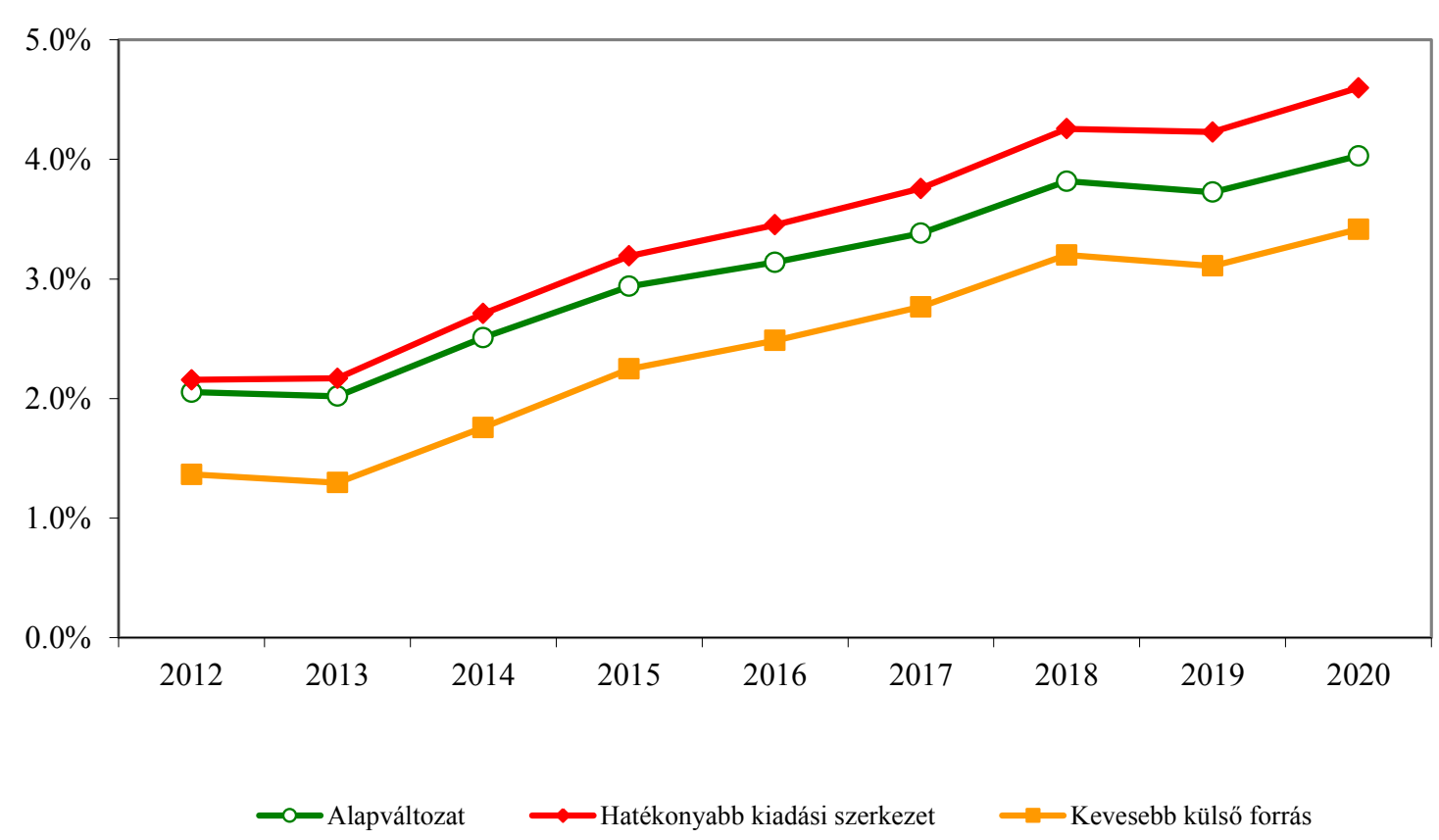

A folyó fizetési mérleg egyenlegének alakulásából az is kiderül, hogy a jövedelemtulajdonosok megváltozott jövedelmi helyzetükre úgy reagálnak, hogy jelentős mértékben a külföldi hitelfelvétel mértékével ellensúlyozzák ezt a hatást. Ez tehát azt jelenti, hogy az első alternatív szcenárióban, mivel nagyobb jövedelemre tesznek szert a hazai szektorok, javul a külfölddel szembeni hitelpozíció, míg a másik alternatív változatban ennek épp a fordítottja történik. 


\section{Értékelés, összefoglalás}

Disszertációmban arra a kérdésre kerestem a választ, hogy az Európai Uniótól érkező transzferek felhasználásával milyen körülmények között és milyen mértékben érhető el e támogatások legfontosabb célja, vagyis az Unió átlagától elmaradó fejlettségü térségek, illetve a magyar gazdaság felzárkózása a fejlettebb régiókhoz.

Ennek megfelelően fogalmaztam meg a kutatási hipotézisemet, aminek értelmében az EUtranszfererek növelik a magyar gazdaság hosszú távú növekedési lehetőségeit. Mindez azt is jelenti, hogy a támogatásoknak nem csak közvetlen keresletnövelő hatása van, hanem a TFP-n keresztül endogén módon is gyorsítják a felzárkózás ütemét. Mivel az elemzéshez alkalmazott modell az endogén növekedéselmélet alapvetésein alapul, logikusnak tünt az eredetileg megfogalmazott kutatási hipotézist azzal a kérdésfelvetéssel kiegészíteni, hogy az EUtranszferek abszolút mennyiségén túlmenően milyen hatása lehet a - növekedései lehetőségeket javító - szerkezeti változásoknak. Azt tételeztem fel, hogy ez a hatás igen jelentős lehet, az alapváltozathoz viszonyított eltérés megközelítheti a transzferek lehívási arányának változásából adódó változást.

A bevezetésben röviden áttekintettem azokat az elméleteket, amelyek az EU-transzferek növekedésgeneráló hatásaival foglalkoznak. Ezek között kiemelt helyen szerepeltek az endogén növekedéselmélet különböző típusai, ez az elméleti háttér ugyanis általánosan elfogadott eszköz az ilyen típusú elemzésekben, a disszertációban alkalmazott modellt is erre a bázisra építettem. Az első fejezetben általánosságban mutattam be az EU-támogatások szerkezetét, majd konkrétan kitértem a Magyarországra érkező pénzösszegek várható szerkezetére.

A második fejezetben az EU-transzferek makrogazdasági hatásairól, valamint a támogatások felhasználásának eredményességéről szóló szakirodalmat dolgoztam fel. Elsősorban olyan modelleket tekintettem át, melyek a magyar gazdaság jelenlegi viszonyai között is alkalmazható módszerekkel operáltak. Ezek közül kiemelt jelentőséggel bír a HERMIN modellcsalád, amelyet kifejezetten a korábbi csatlakozó országok felzárkózási pályájának vizsgálatára fejlesztettek ki. Ezen túlmenően ebben a fejezetben tekintettem át az uniós transzferek hatásvizsgálatával foglalkozó esettanulmányokat és ökonometriai becsléseket. Az 
utolsó két alfejezetben feldolgozott tanulmányos többsége pozitív hatást tulajdonít az uniós támogatásokra, ugyanokkor egyes szerzők felhívják e figyelmet az esetleges negatív hatásokra is. Saját eredményeim is azt jelzik, hogy az EU-transzferek alapvetően kedvezően hatnak a felzárkózási folyamatra, azonban a lehetőségek teljes körü kiaknázásához komoly erőfeszítések szükségesek a helyi és az országos szintü döntéshozatalban egyaránt. A harmadik fejezetben a hosszú távú modellezés nemzetközi és hazai tapasztalatait foglaltam össze.

A negyedik fejezetben részletesen bemutattam az alkalmazott modell müködési mechanizmusait, valamint a konkrét egyenleteket. A modell egzogén változói részben a számunkra adottságként tekinthető világgazdasági környezet alakulását írják le, részben pedig gazdaságpolitikai eszközváltozók. A modell számos olyan paramétert is tartalmaz, amelyek a gazdasági ágensek viselkedését jellemzik. A külgazdasági környezetet jellemző változók alakulására szakértői becsléseket kell figyelembe venni, míg a gazdaságpolitikai eszközváltozók az adott forgatókönyvhöz tartozó fiskális és monetáris politikai elképzeléseket jelenítik meg. A paraméterek értékeit statisztikai idősorokon alapuló becslések, ill. múltbeli tapasztalatok és szakértői becslések alapján határozzuk meg. A modell endogén változóinak értékei az egzogén változók és a konkrét paraméterértékek függvényében alakulnak ki a dinamikus szimulációs futtatások során. A modell részben (ökonometriai módszerekkel számszerüsített) sztochasztikus, részben determinisztikus (mérleg-) egyenleteket tartalmaz. A modellben négy fő szektort különböztetünk meg: ezek a háztartási szektor, az államháztartási szektor, a vállalati szektor (amely a pénzügyi szektort is magában foglalja) és a külgazdasági szektor.

Az utolsó fejezet első alfejezetében a modell stabilitását vizsgáltam meg. A kapott impulzus válasz függvények azt jelzik, hogy az esetleges sokkok belátható időn belül lecsengenek, így a modell kellően stabilnak tekinthető. A második alfejezetben a modell elörejelző-képességét teszteltem. Az ex post elemzés során kellően jó illeszkedéseket kaptam, ami azt jelzi, hogy a modell hosszú távon is megfelelö elörejelző-képességgel bír. Ezután előrejelzést és szcenárióelemzést végeztem. Ennek során a legvalószínűbbnek tekintett feltételrendszer mellett készítettem hosszú távú elörejelzéseket az endogén változókra, ezek összességét tekintve alapváltozatnak. Összefoglalva elmondható, hogy alapesetben minimális mértékü felzárkózás valószínűsíthető a vizsgált időszakban. 
Az eredmények részletes ismertetése után két másik szcenárióra is elkészítettem az előrejelzéseket, ezek segítségével mértem az EU-transzferek hatásait. Az egyik esetben javuló kiadási szerkezetet, a másikban romló abszorpciós képességet tételeztem fel.

A modellem segítségével végzett számítások megerősítették a disszertáció kutatási hipotézisét. Az első alternatív szcenárióban kapott eredmények azt mutatják, hogy amennyiben a ténylegesen felhasznált uniós források aránya a keretösszeg 75 százalékáról annak 50 százalékára csökken, akkor ez önmagában közel 0,1 százalékponttal csökkenti a GDP átlagos növekedési ütemét. Ez azt eredményezné, hogy az EU27 átlagában kifejezett vásárló-erőparitáson mért GDP szintje 0,4 százalékponttal maradna el az alapváltozatban szereplö értéktől.

A második alternatív szcenárióban kapott eredmények szerint amennyiben a $\mathrm{K}+\mathrm{F}$ tevékenységet, a humántőke fejlesztését és az innovációt fokozottabban támogató szerkezetben használjuk fel az uniótól kapott transzfereket, mintegy 0,1 százalékponttal gyorsulhat a GDP növekedése a 2020-ig terjedő időszakban. Így az időszak végére 0,4 százalékponttal lehet magasabb a vásárló-erőparitáson mért GDP szintje az alapváltozathoz képest. Mindezek alapján kijelenthető, hogy a második hipotézis is megerősítést nyert. Ezt nagyon fontos eredménynek tartom egy olyan időszakban, amikor az unió politikusai épp végletekig kiélezett vitát folytatnak arról, hogy melyik tagállam mennyi támogatáshoz juthat, miközben a transzferek szerkezete leginkább különalkuk, vélt vagy valós nemzeti érdekek, és egyéb politikai szempontok alapján alakul.

Az egyes szcenáriókat összehasonlítva jelentős eltéréseket tapasztaltam a folyó fizetési mérleg egyenlegének alakulásában, miközben alig változott a háztartások rendelkezésre álló jövedelme. Ez azt jelenti, hogy az ország változó jövedelemtermelő képessége elsősorban a külső pozíció változásában csapódik le, a lakosság jövedelmi viszonyai csak mérsékelten reagálnak a GDP változására. Az elmúlt évek gazdasági folyamatai ennek egyáltalán nem mondanak ellent, számos példát találhatunk arra, amikor a két mutató alakulása tartósan elszakadt egymástól. A 6. számú táblázat néhány fontosabb gazdasági mérőszám 2020-ra becsült értékét mutatja az egyes változatokban. 
A hosszú távú gazdasági folyamatok várható alakulása

\begin{tabular}{|l|c|c|c|}
\hline & \multicolumn{2}{|c|}{2020} \\
\cline { 2 - 4 } & Alapszcenárió & $\begin{array}{c}\text { Hatékonyabb } \\
\text { kiadási szerkezet }\end{array}$ & $\begin{array}{c}\text { Kevesebb külső } \\
\text { forrás }\end{array}$ \\
\hline $\begin{array}{l}\text { Az egy före jutó GDP vásárlóerö- } \\
\text { paritáson, az EU27 százalékában }\end{array}$ & $66,9 \%$ & $67,3 \%$ & $66,5 \%$ \\
\hline $\begin{array}{l}\text { Az egy före jutó rendelkezésre álló } \\
\text { jövedelem vásárlóerö-paritáson, az } \\
\text { EU27százalékában }\end{array}$ & $52,2 \%$ & $52,3 \%$ & $52,0 \%$ \\
\hline $\begin{array}{l}\text { Államháztartási egyenleg a GDP } \\
\text { százalékában }\end{array}$ & $-1,9 \%$ & $-1,8 \%$ & $-1,8 \%$ \\
\hline $\begin{array}{l}\text { Folyó fizetési mérleg egyenlege a GDP } \\
\text { százalékában }\end{array}$ & $4,0 \%$ & $4,6 \%$ & $3,4 \%$ \\
\hline
\end{tabular}

Modellszámítási eredményeim más szerzők empirikus adataival is egybecsengenek. A bevezetőben említett Li[2002] és Barro - Sala-i-Martin [1995] számításai egyaránt megerősítik a hipotézisben megfogalmazott állítást. Hasonló következtetésre jut Kocziszky [2011], aki a korábban csatlakozó országok példája kapcsán azt is megemlíti, hogy a régiók közötti fejlettségbeli különbségek növekedése már most is gátja a gyorsabb felzárkózásnak. Elekes [2011] szerint a gyorsabb felzárkózás érdekében elsősorban a $\mathrm{K}+\mathrm{F}$ beruházások növelése, az innováció segítése és a humántőke fejlesztése lenne kívánatos. Ezek épp azok a területek, amelyek az endogén növekedési modellekben a TFP hagyományos magyarázó változói, és az általam használt modellben is ezek a változók magyarázzák teljes tényező termelékenységet. A szerző ugyanakkor rámutat arra is, hogy az említett területek előtérbe helyezése átmenetileg növelheti a regionális különbségeket.

Érdekesség, hogy a két szcenárióban nagyjából azonos mértékü, de természetesen ellenétes irányú elmozdulásokat tapasztaltam. Az egybeesés persze részben a véletlen műve, az viszont fontos eredmény, hogy a két alternatív szcenárióban jelzett eltérések azonos nagyságrendűek. Ebből ugyanis azt a tanulságot lehet leszürni, hogy érdemes ugyan erőfeszítéseket tenni annak érdekében, hogy minél több pénzhez jussunk az Uniótól, majd azért, hogy ezekez a 
támogatásokat le is tudjuk hívni, de a hosszú távú gazdasági növekedést az is meghatározza, hogy ezeket az összegeket milyen hatékonyan vagyunk képesek elkölteni.

Összességében úgy ítélem meg, hogy a disszertáció elején kitűzött cél sikerült elérnem: a kutatási hipotézisekre pozitív válaszokat tudtam adni, a modellszámítások eredményei pedig megfelelnek az előzetes várakozásoknak és összhangban vannak a szakirodalomban található empirikus eredményekkel. 


\section{Felhasznált irodalom}

1. Aghion, P. - P. W. Howitt [1998]: Endogenous growth theory, Cambridge, Mass.: MIT Press

2. Arrow, K. [1962]: The Economic Implications of Learning by Doing, Review of Economic Studies, June, 155-173.o.

3. Azariadis, C. - Drazen, A. [1990]: Thershold Externalities in Economic Development, Quarterly Journal of Economics, 105. 501-526. o.

4. Bachtler, J. - S. Taylor [1996]: Regional development strategies in Objective 2 regions: A comparative assessment, Regional Studies, vol. 30, pp. 723-32. 1996. december

5. Bachtler, J. - I. Turok [1997]: The coherence of EU regional policy: Contrasting perspectives on the Structural Funds, Jessica Kingsley: London

6. Bachtler, J. - Gorzelak, G. [2007]: Reforming EU Cohesion Policy. A Reappraisal of the Performance of the Structural Funds, Routledge, Policy Studies, Vol. 40, No. 4, pp. 309-326.

7. Balassa, B. [1964]: The Purchasing Power Doctrine: a Reappraisal, Journal of Political Economy 72, 584-96.

8. Barabás Gy. - Major K. [2001]: A monetáris program - módszertani leírás, MNB Mühelytanulmányok 2001/21.

9. Barro, R. J. - Sala-i-Martin, X. [1995]: Economic Growth, McGraw-Hill Inc., New York.

10. Barry, F. - Devereux, M. B. [2003]: Expansionary fiscal contraction: A theoretical exploration, Journal of Macroeconomics 25 (2003) pp 1-23. 
11. Bauer, P. - Gábriel, P. [2009]: Inflációs perzisztencia a traded és a nontraded szektorban, MNB-tanulmányok, No. 82, 2009.

12. Becker, G. S. - Murphy, K. M. - Tamura, R. [1990]: Human Capital, Fertility, and Economic Growth, Journal of Political Economy, University of Chicago Press, vol. 98(5), pp. S12-37, October

13. Bencivenga, V. R. - Smith, B. D. [1991]: Financial Intermediation and Endogenous Growth. Review of Economic Studies, 58. 195-209. o.

14. Benczúr P. - Simon A. - Várpalotai V. [2003]: Fiskális makropolitika és a növekedés elemzése kalibrált modellel, MNB Füzetek, 2003/13.

15. Benk Sz. - Jakab M. Z. - Kovács M. A. - Párkányi B. - Reppa Z. - Vadas G. [2006]: The Hungarian Quarterly Projection Model (NEM), MNB Occasional Papers, 60.

16. Beutel, J. [2002]: The economic impact of objective 1 interventions for the period 2000 - 2006, Final report to the Directorate General for Regional Policies, 2002. május http://europa.eu.int/comm/regional_policy/sources/docgener/studies/pdf/objective1/final _report.pdf, letöltés dátuma: 2007. szeptember 26.

17. Bodenstein, T. -Kemmerling, A [2011]: Ripples in a Rising Tide: Why Some EU Regions Receive More Structural Funds than Others, European Integration Online Papers (EIoP), Vol. 16, Article 1.

18. Boldrin, M. - F. Canova [2001]: Inequality and convergence in Europe's regions: Reconsidering European regional policies, Economic Policy, vol. 16, No. 32, pp. $205-$ 53

19. Bradley, J - J. Fitz Gerald [1998]: Industrial output and factor input determination in an econometric model of a small open economy, European Economic Review, Elsevier, vol. 32, pp. 1227-1241. 1988. július 
20. Bradley, J. - Gács J. - A. Kangur - N. Lubenets [2003]: Macro impact evaluation of National Development Plans - A tale of Irish, Estonian and Hungarian collaborations, Paper presented at the Fifth European Conference on Evaluation of the Structural Funds, Budapest, 2003. június www.ec.europa.eu/regional_policy/sources/docconf/budapeval/ work/kangur.doc, letöltés dátuma: 2007. április 16.

21. Bradley, J. - Gács J. - A. Kangur - N. Lubenets [2005]: HERMIN: A macro model framework for the study of cohesion and transition, In: Integration, Growth and Cohesion in an Enlarged European Union, ZEI Studies in European Economics and Law, Vol. VII, 2005. december

22. Bradley, J. - L. Modesto - S. Rivero [1995]: HERMIN: A Macroeconometric Modelling Framework for the EU Periphery, Economic Modelling, vol. 12, No. 3, pp. 221-247. 1995. április

23. Bradley, J. - E. Morgenroth [2004]: A study of the macro-economic impact of the reform of EU cohesion policy, The Economics and Social Research Insititute, 2004. október

24. Bradley, J. - E. Morgenroth - G. Untiedt [2003]: Macro-regional evaluation of the Structural Funds using the HERMIN modelling framework, Paper for presentation at the 43rd Congress of the European Regional Science Association, http://www.ersa.org/ersaconfs/ersa03/cdrom/papers/313.pdf, letöltés dátuma: 2007. május 8.

25. Bradley, J. - Untiedt, G. [2008]: EU Cohesion Policy and 'Conditional Effectivness'. What do Cross-Section Regression Tell Us?, in GEFRA Working Paper, No. 4, May 2008.

26. Bradley, J.- K. Whelan - J. Wright [1995]: HERMIN Ireland, Economic Modelling, vol. 12, No. 3, pp. 249-274. 1995. április 
27. F.A.G. den Butter - F.J. Wollmer [1996]: An empirical model for Endogenous Technology in the Netherlands (Az endogén fejlödés empirikus modelljének alkalmazása a holland gazdaságra). Economic Modelling, 13, pp. 15-40, 1996

28. Cappelen, A. - F. Castellaci - J. Fagerberg - B. Verspagen [1997]: The impact of regional support on growth and convergence in the European Union, Centre for Technology, Innovation and Culture, University of Oslo, WP12

29. Colinsk, J. [1967]: A Modified Neo-classical Growth Model with Endogenous Technical Change, Southern Economic Journal, October.

30. Cserháti I. - Erni T. - Keresztély T. [2004]: Hosszú távú növekedési szcenáriók elemzése az ECO-TREND modellel, A gazdaságelemzés módszerei 2004/I. szám (ECOSTAT kiadvány)

31. Dall'erba, S. - Guillain, R. - Le Gallo, J. [2009]: Impact of Structural Funds on Regional Growth: How to Reconsider a 9 Year-Old Black Box, Region et Developpement, LEAD, Universite de Sud - Toluon Var, No 30, pp 77-99.

32. Danquah, M. - Moral-Benito, E. - Quattara, B. [2011]: TFP Growth and its Determinants: Nonparametrics and Model Averaging, Documentos de Trabajo, No 1104, Banco de Espana.

33. Darvas Zs. - Simon A. [1999]: A növekedés makrogazdasági feltételei, MNB Füzetek, $1999 / 3$

34. Dedák I. [2000]: A gazdasági felzárkózás növekedéselméleti összefüggései, Közgazdasági Szemle, XLVII. évf., pp. 411-430. 2000. június

35. Domar, E. D. [1946]: Capital Expansion, Rate of Growth, and Employment. Econometrica, Vol. 14., April, 137-147.o.

36. Dumciuviene, D. [2009]: European Union Cohesion Policy Implementation for Growth. Economics \& Management, 2009/14 
37. Dumciuviene, D. [2011]: Economic Development and Cohesion Policy as Financial Instrument. Economics \& Management, 2011/16

38. Ederveen, S. - de Groot, H. - Nahuis, R. [2002]: Fertile soil of Structural Funds? - A panel data analysis of the conditional effectiveness of European cohesion policy, CPB Discussion Paper, No. 10.

39. Ederveen, S.- Gorter J. -De Mooij R.- Nahuis R. [2003]: Funds and Games, The Economics of European Cohesion Policy, ENEPRI, Occasional Paper No. 3.

40. Ederveen, S., de Groot, H. and Nahuis, R. [2006], Fertile Soil for Structural Funds? A Panel Data Analysis of the Conditional Effectiveness of European Cohesion Policy, Kyklos, Vol. 59, No. 1, pp. 17-42.

41. Elekes, A. [2011]: Kohézió és/vagy növekedés. Pénzügyi Szemle, 2011/1, pp. 107-123.

42. Elhorst, J. P. - Oosterhaven, J. [2006]: Forecasting the impact of transport improvements on commuting and residential choice. J Geograph Syst (2006) 8: pp. 3959

43. Ernst \& Young [1996], Synthesis report: Ex -post evaluation of the 1989-93 Objective 2 programmes

44. ESRI [2002]: An examination of the ex-post macroeconomic impacts of CSF 1994-99 on Objective 1 countries and regions, www.ec.europa.eu/regional_policy/sources/ docgener/evaluation/doc/obj1/macro_modelling.pdf, letöltés dátuma: 2007. szeptember 24.

45. Esty, D. C. et al [2008], Environmental Performance Index, New Haven: Yale Center for Environmental Law and Policy. Available at http://epi.yale.edu, accessed 8 June 2008.

46. European Commission [1999]: Better management through evaluation, Mid-term review of Structural Funds programmes: Objectives 1 and 6, Luxembourg: Office for official publications of the European Communities 
47. European Commission [1999]: The socio-economic impact of projects financed by the Cohesion Fund: A modelling approach, Luxembourg: Office for official publications of the European Communities

48. European Commission [2001]: Unity, solidarity, diversity for Europe, its people and its territory - Second report on economic and social cohesion

49. European Commission [2001]: Working for the regions, Europe on the move, Catalogue number: KN-28-00-220-EN-C

50. European Commission [2004]: A new partnership for cohesion convergence competitiveness cooperation - Third report on economic and social cohesion

51. European Commission [2004]: EU Economy 2004 Review, Chapter 2: Catching-up, Growth and Convergence of the New Member States, www.ec.europa.eu/ economy finance/publications/european economy/2004/ee604ch2 en.pdf, letöltés dátuma: 2007. április 24.

52. European Commission [2009]: Sourcebook 2, Methods \& Techniques, Macroeconomic Models, 2009. november. Elérhető itt: http://ec.europa.eu/regional policy/sources/ docgener/evaluation/evalsed/sourcebooks/method_techniques/modelling/macroeconomi c models/macroeconomic details_en.htm, letöltés dátuma: 2011. október 24.

53. Farole, T. - Rodriguez-Pose, A. - Storper, M. [2009]: Cohesion Policy in the European Union: Growth, Geography, Institutions, Report Working Paper, European Comission.

54. Fayolle, J. - Lecuyer, A. [2000]: Regional growth, national membership and European structural funds: an empirical appraisal, OFCE Working Paper No. 00-02

55. de La Fuente, A. [2002]: The effect of Structural Fund spending on the Spanish regions: an assessment of the 1994-99 objective 1 CSF, International Macroeconomics, Discussion Paper Series, No. 3673 
56. de la Fuente, Á. - A. Ciccone [2002]: Human capital in a global and knowledge-based economy - European Commission, Directorate-General Employment for Employment and Social Affairs kiadványa, (http://europa.int/comm/employment_social honlapon is részben megtalálható)

57. García Solanes, J. - María -Dolores R. [2001]: The impact of structural funds on economic convergence in European countries and regions, Mimeo

58. Gáspár P. - Ludányi A. [1998]: A magyar gazdaság növekedési potenciálja és a világgazdasági trendek hatása, Pénzügykutató Rt., 1998. november

59. Glomm, G. - Ravikumar, B. [1992]: Public versus Private Investment in Human Capital: Endogenous Growth and Income Inequality. Journal of Political Economy, 100. 818-834. o.

60. Harrod, R. F. [1939]: An Essay in Dynamic Theory. The Economic Journal, Vol. XLIX., March, 14-33.o.

61. Herce, J.-A. - S. Sosvilla-Rivero [1995]: HERMIN Spain, Economic Modelling, 12, No. 3, pp. 295-311. 1995. április

62. Horváth Á. - Köber Cs. - Szilágyi K. [2011]: Az MNB Monetáris Politikai Modellje, az MPM, MNB-Szemle, 2011. június, 18-24. o.

63. Huggins, R. [1998]: An evaluation of European Union Objective 2 programmes in industrial South Wales, 1989-93, European Urban and Regional Studies, 4.

64. IBO [2001]: The financing of the EU structural policy in the context of the enlargement of the $E U$

65. Ionescu, R - Tudor, F [2011]: Modeling the Impact of the European Cohesion Policy Under the Present Crisis, Economics, Management, and Financial Markets, Volume 6(2), 2011, pp. 853-867 
66. Ivanova, O. et al [2007]: RAEM: version 3.0, First Report. Transport \& Mobility Leuven, 2007. október

67. Jones, C. I. [1995]: Time Series Tests of Endogenous Growth Models, The Quarterly Journal of Economics, Vol. 110, Issue 2, pp. 495-525.

68. Kamps, C. - Leiner-Killinger, N. - Martin, R. [2009]: The Cyclical Impact of EU Cohesion Policy in Fast Growing EU Counties, Intereconomics, 2009/január-február, pp. 23-29.

69. Keresztély T. [2004]: Elörejelzés és szcenárióelemzés hosszú távú makromodellel, Statisztikai Szemle, 2004. október-november

70. Koschatzky, K. - Stahleckker, T. [2010]: A new Challenge for Regional Policy-Making in Europe? Chances and Risks of the Merger Between Cohesion and Innovation Policy. European Planning Studies Vol. 18, No. 1, January 2010, pp. 7-26.

71. Kocziszky, Gy. [2011]: Megállitható-e a területi diszparitások növekedési üteme? Adalékok regionális politikánk újragondolásához, Pénzügyi Szemle, 2011/3, pp. 313323.

72. Kotosz, B. [2006]: Megszoritások és lazitások - A rendszerváltás fiskális politikájának szerkezetéröl. Közgazdasági Szemle, Vol. 53, no 2. pp. 158-174.

73. Kovács M. A. [1999]: Reálárfolyam-mutatók és a magyar gazdaság ár-és költségversenyképessége, Közgazdasági Szemle, XLVI. évf., 1999. február (145-175. o.)

74. Krugman, P. [1991]: Increasing Returns and Economic Geography, Journal of Political Economy, vol. XCIX, pp. 483-499.

75. Kuznets, S. [1955]: Economic Growth and Income Inequality, in: American Economic Review 65, pp. 1-28.

76. Levine, R. [1992]: Financial Intermediary Services and Growth. Journal of the Japanese and International Economies, 6. 383-405. o. 
77. Li, D. [2002]: Is the AK Model Still Alive? The Long-Run Relation between Growth and Investment Re-examined, Canadian Journal of Economics, 35, pp. 92-114.

78. Lolos, S. [1998]: Success and failure of economic policies: The experience of Greece and Portugal, Comparative Economic Studies, 40(1), pp. 72-102.

79. Lucas, R. E. [1988]: On the mechanics of economic development, Journal of Monetary Economics, Vol. 22., Iss. 1. pp. 3-42. 1988. július

80. Malley, J. - T. Moutos [1994]: A Prototype Macroeconomic Model of Foreign Direct Investment, Journal of Development Economics, 43, pp. 295-315. 1994. április

81. Mankiw, N. G. - Romer, D. - Weil, D. [1992]: A Contribution to the Empirics of Economic Growth, Quarterly Journal of Ecomonics, Vol.107. 407-437.o.

82. Meyer D. [1995]: Az új növekedéselmélet, Közgazdasági Szemle, XLII. évf., pp. 387398. 1995. április

83. Meyer D. [2005]: Az új gazdaságföldrajz gazdaságpolitikai implikációi növekedéselméleti megközelitésben, „Gazdasági növekedés Magyarországon” konferenciakötet, 3. fejezet, Müegyetemi Kiadó, 2005.

84. MNB [2000]: A háztartások nettó pénzügyi vagyonának és a vagyonváltozás összetevőinek mérését bemutató módszertan, - a Statisztikai Főosztály tanulmánya

85. MNB [2006]: Elemzés a konvergenciafolyamatokról - az MNB Közgazdasági és monetáris politikai szakterületének tanulmánya, 1996. december

86. Móczár, J. [2008]: Fejezetek a modern közgazdaságtudományból, Akadémiai Kiadó, Budapest, 2008

87. Modesto, L.- P. D. Neves [1995]: HERMIN Portugal, Economic Modelling, Vol. 12, No. 3, pp. 275-294. 1995. április 
88. National Technical University of Athens: The GEM-E3 model reference manual. http://gem-e3.zew.de/geme3ref.pdf

89. Oblath G. [1999]: A maastrichti szerzödés fiskális kritériumai és a hazai államháztartási helyzet értelmezése, Közgazdasági Szemle, XLVI. évf., pp. 851-872. 1999. október

90. Padam, S - Ehrlich, U - Tenno, K [2010]: The impact of EU Cohesion policy on environmental sector sustainability in the Baltic states, Baltic Journal of Economics 10(1) (2010) pp. 23-41.

91. Percoco, M. [2005]: The impact of Structural Funds on the Italian Mezzogiorno, 19941999, Région et Développement, No. 21

92. Perger, É. [2009]: EU kohéziós támogatások felhasználásának intézményrendszere és a forrásfelhasználás hatékonysága, eredményessége, ECOSTAT kiadvány, 2009. Elérhető itt: http://kozigkut.uw.hu/doc/perger_09szept.pdf, letöltés dátuma: 2011. november 10.

93. Pollitt, H. - Chewpreecha, U. - Summerton, Ph. [2007]: E3ME: An EnergyEnvironment-Economy Model for Europe, Version 4.2: A Technical Description for petrE WP3. 2007.

94. Rebelo, S. [1991]: Long-Run Policy Analysis and Long-Run Growth, Journal of Political Economy, University of Chicago Press, vol. 99(3), pp. 500-521. 1991. június

95. Rickman, D. S. [1995]: A Bayesian Analysis of the use of pooled coefficients in a structural regional economic model, International Journal of Forecasting 11

96. Robinson, S. - A. Catteano - M. El-Said. [2001]: Updating and estimating a Social Accounting Matrix Using Cross Entropy Methods, Economic Systems Research, 13., No. 1. 
97. Roeger, W. [1996]: Macroeconomic evaluation of the effects of CSF with QUEST II (paper presented at the European Conference on evaluation methods for Structural Funds intervention, Berlin 2-3 Dec. 1996).

98. Roeger, W. - J. in't Veld [1997]: QUEST II - A multi country business cycle and growth model, Economic Papers. No. 123. 1997. október

99. Roeger, W. - J. in't Veld [2002]: Some selected simulation experiments with the European Comission's QUEST model, European Economy. Economic Papers. No. 178. 2002. október

100. Romer, P.M. [1986]: Increasing Returns and Long Run Growth, Journal of Political Economy, 94(5), pp. 1002-37.

101. Romer, P. [1994]: The Origins of Economic Growth. Journal of Economic Perspectives, 8. 3-22. o.

102. Solow, R. M. [1956]: A Contribution to the Theory of Economic Growth. Quarterly Journal of Economics, Vol. 70., February, 65-94.o.

103. Solow, R. M. [1960]: Investment and Technical progress. In Stiglitz, J. E. Uzawa, H. (eds.) [1969]: Readings in the Modern Theory of Growth. The M.I.T. Press, London. 156-171.o.

104. Spiridonovs, J [2011]: Impact Evaluation of EU Funds: Examples in Infrastructure Projects, Business: Theory and Practice, 2011 12(2): pp. 113-119

105. Sturm, J.-E. - G. H. Kuper - J. de Haan [1996]: Modelling government investment and economic growth at the macro level: A review, CCSO Series No. 29., Dept. of Economics, University of Groningen

106. Surányi Gy. - Vincze J. [1998]: Infláció Magyarországon, In: Cottarelli-Szapáry: Mérsékelt infláció. Magyar Nemzeti Bank, Budapest 
107. Swan, T. W. [1956]: Economic Growth and Capital Accumulation, Economic Record, 32, November, 334-361.o.

108. Tamura, R. [1991]: Income Convergence in an Endogenous Growth Model, Journal of Political Economy, 99. 523-540. o.

109. Tóth I. Gy. [1999]: Conflicting Expectations, Decreasing Rate of Growth, TÁRKI Business Cycles Research Papers, 21, 1999. szeptember

110. Tsang, S. - Y. Ma [1997]: Simulating the Impact of Foreign Capital in an Open Economy Macroeconomic Model of China, Economic Modelling, 14, pp. 435-478

111. Valentinyi Á. [1995]: Endogén növekedéselmélet, Közgazdasági Szemle, XLII. évf., pp. 582-594. 1995/6

112. Varga A. - H. J. Schalk [2004]: Macroeconomic effects of the geography of knowledge production: EcoRET, a macroeconometric model with regionally endogenized technological change for Hungary, European Regional Science Association conference papers, 2004. augusztus

113. Varga A. [2007]: GMR-Hungary: A Complex Macro-Regional Model for the Analysis of Development Policy Impacts on the Hungarian Economy. Working Paper, 2007/4, Pécsi Tudományegyetem

114. Varga A. [2011]: Modeling the growth effects of $R \& D$ subsidies: The GMR-Europe model and its application for EU Framework Program policy impact simulations, Pécsi Tudományegyetem, 2011. Elérhető itt: http://dimetic.dime-eu.org/dimetic files/ A\%20Varga\%20GMR.pdf, Letöltés ideje: 2012. január 7.

115. Varga J. - in 't Veld, J. [2011]: A model-based analysis of the impact of Cohesion Policy expenditure 2000-06: Simulations with the QUEST III endogenous R\&D model. Economic Modelling 28 (2011) pp. 647-663.

116. in't Veld, J. [2007]: The potential impact of the Fiscal Transfers under the EU Cohesion Policy Programme, European Economy, Economic Papers, No. 283. 
117. Williamson, J. [1965]: Regional inequality and the process of national development, in: Economic Development and Cultural Change 14, pp. 3-45.

www.euvonal.hu

www.europa.eu

www.nfu.hu 


\title{
MELLÉKLETEK
}

\author{
1. sZ. MELLÉKLET
}

Az modell alkalmazásakor használt EViews programfájl

' ADATOK BEOLVASÁSA AZ EXCEL ADATBANKBÓL

close *

open d:levesmodelllevesmodell.wf1

smpl 19902021

delete *

read(c7,t,s=input) d:levesmodelllevesadatbank.xls 248

smpl 19912021

read(c5,t,s=exog) d:levesmodelllevesadatbank.xls 157

smpl 19982021

$\operatorname{read}(\mathrm{b} 5, \mathrm{~s}=$ fogl) $\mathrm{d}$ :levesmodelllaht.xls 11

smpl 19992021

'read(c7,t,s=aht) d:levesmodelllaht.xls 70

smpl 19992021

read(c3,t,s=aht-funkc) d:levesmodellaht.xls 20

smpl 19992021

$\operatorname{read}(\mathrm{b} 2, \mathrm{t}, \mathrm{s}=$ PARFE) d:levesmodelllfunkc-ESA.xls 122

smpl 19992021

'read(c6,t,s=te) d:levesmodelllaht.xls 32

smpl 19902021

genr qinvbu $0=$ qinvbu

genr qinvpu $0=$ qinvpu

delete ser $^{*}$

' AZ AKTUÁLIS MODELL-LEÍRÁS GENERÁLÁSA

model EVESMODELL

EVESMODELL.append assign @all for

'GDP ÖSSZEHASONLÍTÓ ÁRON 
EVESMODELL.append dLOG(QCPUR)=PARAM11*dLOG(B6HOUS/CPI)+PARAM14*DEPORATE/CPI*CPI(1)+A1SUM

EVESMODELL.append QTERM $=X T E R M / C P I T E R M$

EVESMODELL.append QONF $=Q O N F(-1)^{*} Q C P U R / Q C P U R(-1)$

EVESMODELL.append $Q C P=Q C P U R+Q T E R M+Q O N F$

EVESMODELL.append QCPUB $=$ XCPUB/CPIXCGOV

EVESMODELL.append $Q C=Q C P+Q C P U B$

EVESMODELL.append dLOG(QINVBU0)=PARAM21*LOANRATE/PPIFT*PPIFT(-

1)+PARAM22*dLOG(D1DOM/ERATEEU/L)+PARAM23*dLOG(BOOM(1))+A2SUM

EVESMODELL.append

D9EUSUMF=D9EUINFF+D9EUHUMF+D9EUPRODF+D9EUINFFS+D9EUHUMFS+D9EUPRODFS

EVESMODELL.append

D7EUSUMF=D7EUINFFIRM+D7EUHUMF+D7EUPRODF+D7EUINFFIRMS+D7EUHUMFS+D7EUPRODFS

EVESMODELL.append

D9EUSUMG=D9EUINFG+D9EUHUMG+D9EUPRODG+D9EUINFGS+D9EUHUMGS+D9EUPRODGS

EVESMODELL.append

D7EUSUMG=D7EUINFG+D7EUHUMG+D7EUPRODG+D7EUINFGS+D7EUHUMGS+D7EUPRODGS

EVESMODELL.append QINVBU=QINVBU0+D9EUSUMF/PINV

'EVESMODELL.append QINVPU0 $=(1+P A R A M 13)^{*}$ QINVPU0(-1)

EVESMODELL.append QINVPU $=X I N V P U / P I N V$

'EVESMODELL.append QINVPU=QINVPU0+D9EUSUMG/PINV

EVESMODELL.append QINVDW=(1+PARAM31)*QINVDW(-1)

EVESMODELL.append QINV=QINVBU+QINVDW+QINVPU

EVESMODELL.append QDSTCK $=(1+\mathrm{PARAM} 41)^{*} \mathrm{QDSTCK}(-1)$

EVESMODELL.append QACC $=$ QINV+QDSTCK

EVESMODELL.append QBELF $=Q C+Q A C C$

EVESMODELL.append dLOG $(Q X)=$ PARAM51*dLOG $(B O O M)+P A R A M 52 * d L O G(D I H E U(-$

1))+PARAM53*dLOG(ERATEEU/D1DOM*L)+A3SUM

EVESMODELL.append QDF $=Q B E L F+Q X$

EVESMODELL.append QM $=$ QDF - QSGDP

EVESMODELL.append KFIRM $=$ KFIRM $(-1)^{*}(1-A M O R T)+$ QINVBU

'EVESMODELL.append TFP $=$ TFP

'EVESMODELL.append dlog(TFP) $=0.001+0.03^{*}$ (par_tfp_0103*fun01d + par_tfp_0408*FUN01e+

par_tfp_0913*FUN04+par_tfp_06*FUN05+par_tfp_07*FUN06+ par_tfp_08*FUN07+par_tfp_0913*FUN08)

EVESMODELL.append funqinvpu $=$ qinvpu/qgdp

EVESMODELL.append TFP $=0.845+$ par_tfp ${ }^{*}\left(\right.$ par_tfp_01 d fun01dsum+par_tfp_01 $\mathrm{e}^{*} \mathrm{FUN01esum+}$ par_tfp_04*FUN04sum+par_tfp_05*FUN05sum+par_tfp_qinvpu*funqinvpu+par_tfp_D9*D9EUSUMF)

'EVESMODELL.append dlog(TFP) $=$ par_tfp* (par_tfp_01 d*fun01dsum+ par_tfp_01 e*FUN01esum+ par_tfp_04*FUN04sum+par_tfp_05*FUN05sum) 
EVESMODELL.append FUN01 =GOVEXP*PARF01

EVESMODELL.append FUN01D=GOVEXP*PARF01D

EVESMODELL.append FUN01E $=$ GOVEXP*PARF01E

EVESMODELL.append FUN02=GOVEXP*PARF02

EVESMODELL.append FUN03=GOVEXP*PARF03

EVESMODELL.append FUN04=GOVEXP*PARF04

EVESMODELL.append FUN05=GOVEXP*PARF05

EVESMODELL.append FUN06 $=$ GOVEXP*PARF06

EVESMODELL.append FUN07=GOVEXP*PARF07

EVESMODELL.append FUN08=GOVEXP*PARF08

EVESMODELL.append FUN09=GOVEXP*PARF09

EVESMODELL.append FUN14=GOVEXP*PARF14

EVESMODELL.append fun01dsum $=$ fun01d + fun01deutr

EVESMODELL.append FUN01esum $=$ FUN01e + FUN01eeutr

EVESMODELL.append FUN01sum $=$ FUN01 + FUN01deutr+ FUN01eeutr

EVESMODELL.append FUN04sum $=$ FUN04 + FUN04eutr

EVESMODELL.append FUN05sum $=$ FUN05

EVESMODELL.append fun01deutr $=($ D7EUPRODG+D7EUPRODGS $) / \mathrm{xgdp}$

EVESMODELL.append FUN01eeutr $=($ D7EUPRODF + D9EUPRODF+D7EUPRODFS + D9EUPRODFS $) / \mathrm{xgdp}$

EVESMODELL.append FUN04eutr $=($ D7EUHUM + D9EUHUMF+D7EUHUMS + D9EUHUMFS $) / x g d p$

\section{EVESMODELL.append}

D1GOV_FUNKC=PARFE01D1*FUN01SUM+PARFE02D 1*FUN02+PARFE03D1*FUN03+PARFE04D1*FUN04S UM+PARFE05D1*FUN05SUM+PARFE06D1*FUN06+PARFE07D1*FUN07+PARFE08D1*FUN08+PARFE09D1* FUN09+PARFE14D1*FUN14

EVESMODELL.append D1GOV=LGOV*WGOV*RATEEARNGOV*(1+RATESSCE)/1000

EVESMODELL.append B2ANDB3GOV=PARAMB2B3*D1GOV

EVESMODELL.append B1GOV_FUNKC=D1GOV+B2ANDB3GOV

EVESMODELL.append B1GOV=B1GOV $(-1)^{*}\left(\right.$ WGOV*LGOV)/(WGOV $\left.(-1)^{*} \operatorname{LGOV}(-1)\right)$

EVESMODELL.append

D3SUM=PARFE01D3*FUN01sum+PARFE02D3*FUN02+PARFE03D3*FUN03+PARFE04D3*FUN04SUM+PARF E05D3*FUN05SUM+PARFE06D3*FUN06+PARFE07D3*FUN07+PARFE08D3*FUN08+PARFE09D3*FUN09+PA RFE14D3*FUN14

EVESMODELL.append

D4GOVEXP=PARFE01D4*FUN01SUM+PARFE02D4*FUN02+PARFE03D4*FUN03+PARFE04D4*FUN04SUM+ PARFE05D4*FUN05SUM+PARFE06D4*FUN06+PARFE07D4*FUN07+PARFE08D4*FUN08+PARFE09D4*FUN 09+PARFE14D4*FUN14 
EVESMODELL.append

D62GOV=PARFE01D62*FUN01SUM+PARFE02D62*FUN02+PARFE03D62*FUN03+PARFE04D62*FUN04SUM +PARFE05D62*FUN05SUM+PARFE06D62*FUN06+PARFE07D62*FUN07+PARFE08D62*FUN08+PARFE09D6 2*FUN09+PARFE14D62*FUN14

EVESMODELL.append D7GOVEXP=PARFE01D7*FUN01SUM+PARFE02D7*FUN02+PARFE03D7*FUN03+PARFE04D7*FUN04SUM+ PARFE05D7*FUN05SUM+PARFE06D7*FUN06+PARFE07D7*FUN07+PARFE08D7*FUN08+PARFE09D7*FUN 09+PARFE14D7*FUN14

EVESMODELL.append D63GOV=PARFE01D63*FUN01SUM+PARFE02D63*FUN02+PARFE03D63*FUN03+PARFE04D63*FUN04sum +PARFE05D63*FUN05SUM+PARFE06D63*FUN06+PARFE07D63*FUN07+PARFE08D63*FUN08+PARFE09D6 $3^{*}$ FUN09+PARFE14D63*FUN14

EVESMODELL.append XCPUB=PARFE01C*FUN01SUM+PARFE02C*FUN02+PARFE03C*FUN03+PARFE04C*FUN04SUM+PARFE05 $C^{\star}$ FUN05SUM+PARFE06C*FUN06+PARFE07C*FUN07+PARFE08C*FUN08+PARFE09C*FUN09+PARFE14C* FUN14+(D7EUINFG+D7EUHUMG+D7EUPRODG+D7EUINFGS+D7EUHUMGS+D7EUPRODGS)

EVESMODELL.append D9GOVEXP=PARFE01D9*FUN01SUM+PARFE02D9*FUN02+PARFE03D9*FUN03+PARFE04D9*FUN04SUM+ PARFE05D9*FUN05SUM+PARFE06D9*FUN06+PARFE07D9*FUN07+PARFE08D9*FUN08+PARFE09D9*FUN 09+PARFE14D9*FUN14

EVESMODELL.append XINVPU=PARFE01INV*FUN01SUM+PARFE02INV*FUN02+PARFE03INV*FUN03+PARFE04INV*FUN04SUM+ PARFE05INV*FUN05SUM+PARFE06INV*FUN06+PARFE07INV*FUN07+PARFE08INV*FUN08+PARFE09INV*F UN09+PARFE14INV*FUN14+(D9EUINFG+D9EUHUMG+D9EUPRODG+D9EUINFGS+D9EUHUMGS+D9EUPR ODGS)

EVESMODELL.append QSGDPFIRM $=$ TFP $^{*} \operatorname{KFIRM}^{\wedge}$ ALFA* $^{*} \operatorname{LIRM}^{\wedge}(1-\mathrm{ALFA})$

'EVESMODELL.append QSGDPGOV = PARAMGDPGOV*QSGDPGOV $(-1)$

'EVESMODELL.append QSGDPHOUS = PARAMGDPHOUS*QGDP

EVESMODELL.append QSGDPGOV_funkc $=$ B1GOV/CPIB1GOV

EVESMODELL.append QSGDPGOV $=$ QSGDPGOV $(-1)^{*} \operatorname{LGOV/LGOV}(-1)^{*} 1.015$

EVESMODELL.append QSGDPHOUS $=$ PARAMQGDPHOUS ${ }^{*}$ QSGDPFIRM

EVESMODELL.append QSGDP = QSGDPFIRM+QSGDPGOV+QSGDPHOUS 
EVESMODELL.append QGDP = QSGDP

'GDP FOLYÓ ÁRON

EVESMODELL.append XCPUR=QCPUR*CPI

EVESMODELL.append XTERM=D63SUM

EVESMODELL.append XONF=XONF(-1)*XCPUR/XCPUR(-1)

EVESMODELL.append XCP $=X C P U R+X T E R M+X O N F$

'EVESMODELL.append XCPUB $=$ XCPUB $(-1)^{*} Q C P U B / Q C P U B(-1)^{*} \mathrm{CPI} / \mathrm{CPI}(-1)$

EVESMODELL.append $X C=X C P+X C P U B$

EVESMODELL.append XINVBU=QINVBU*PINV

'EVESMODELL.append XINVPU=QINVPU*PINV

EVESMODELL.append XINVDW=QINVDW*PINV

EVESMODELL.append XINV=XINVBU+XINVPU+XINVDW

EVESMODELL.append XDSTCK $=X D S T C K(-1)^{\star}$ QDSTCK/QDSTCK $(-1)^{*} P I N V / P I N V(-1)$

EVESMODELL.append XDSTCKFIRM=PARAMXDSTCKFIRM*XDSTCK

EVESMODELL.append XDSTCKHOUS=(1-PARAMXDSTCKFIRM)*XDSTCK

EVESMODELL.append XINVDWHOUS=PARAMXINVDWHOUS*XINVDW

EVESMODELL.append XINVDWNPR=(1-PARAMXINVDWHOUS) ${ }^{*} X I N V D W$

EVESMODELL.append XACC $=X I N V+X D S T C K$

EVESMODELL.append XBELF $=X C+X A C C$

EVESMODELL.append $X X=Q X^{*} P E X P$

EVESMODELL.append $X M=Q M^{*} P I M P$

EVESMODELL.append XDF $=X B E L F+X X$

EVESMODELL.append XGDP1 $=$ XBELF $+X X-X M$

EVESMODELL.append XGDP $=$ XGDP1 + XGDP_AD

\section{'ÁRAK-BÉREK}

'EVESMODELL.append ERATEEU=ERATEEU $(-1)^{*}(1+\mathrm{DEVAL})$

EVESMODELL.append ERATEDOL=ERATEEU/CROSS

EVESMODELL.append PIMP=PIMP(-1)*WPIIMPEU/WPIIMPEU(-1)*ERATEEU/ERATEEU(-1)

EVESMODELL.append PEXP=PEXP $(-1)^{\star}$ WPIEXPEU/WPIEXPEU $(-1)^{\star}$ ERATEEU/ERATEEU(-1)

\section{'EVESMODELL.append}

$\mathrm{dLOG}(\mathrm{PPIFT})=$ PARAM71*dLOG(PIMP)+PARAM72*dLOG(D1DOM/L)+PARAM73*dLOG(PEXP)+A5SUM

EVESMODELL.append PPIFT $=(1+P A R A M 82)^{*} P P I F T(-1)$

EVESMODELL.append PINV=PINV(-1)*PPIFT/PPIFT(-1)

EVESMODELL.append

dLOG(CPI)=PARAM94*dLOG(CPIEXPECT)+PARAM96*dLOG(EARNINGDOM)+PARAM97*dLOG(PPIFT)+A6S UM

'EVESMODELL.append CPI1=CPI1 $(-1)^{*}(1+\mathrm{PARAM} 81)$

EVESMODELL.append CPITERM=CPITERM $(-1)^{\star}(1+$ PARAM83)

EVESMODELL.append dLOG(WFIRM)=PARAM91*dlog(CPIEXPECT)+PARAM92*dLOG(PRODL(-

1))+PARAM93*URATE(-1)+A7SUM 
EVESMODELL.append EARNINGDOM1= PARAMW*XGDP

EVESMODELL.append EARNINGDOM $=W * L{ }^{*}$ RATEEARN $/ 1000$

'EVESMODELL.append WGOV=W

EVESMODELL.append $W=\left(L^{2}\right.$ GOV*WGOV+LFIRM*WFIRM $) / L$

EVESMODELL.append EARNINGGOV=WGOV*LGOV*RATEEARN/1000

'EVESMODELL.append EARNINGDOM=W*L

EVESMODELL.append D1DOM $=(1+R A T E S S C E) * E A R N I N G D O M$

'EVESMODELL.append D1GOV=(1+RATESSCE)*EARNINGGOV

\section{'MUNKAERŐ}

'EVESMODELL.append LNOV=QGDP/QGDP(-1)-PRODL/PRODL(-1)

'EVESMODELL.append PRODL=PRODL(-1)*(1+PARAMPRODL)

EVESMODELL.append PRODL=QGDP/L

'EVESMODELL.append $\mathrm{L}=\mathrm{L}(-1)^{*}(1+\mathrm{LNOV})$

EVESMODELL.APPEND LOG(LFIRM)=PARAM84*LOG(LFIRM(-1))+PARAM85*LOG(QGDP(-1))+A8SUM

'EVESMODELL.append LGOV=LGOV

EVESMODELL.append L=LFIRM+LGOV

EVESMODELL.append SL=ACTAGE*ACTRATE

EVESMODELL.append U $=S L-L$

EVESMODELL.append URATE=U/SL

'JÖVEDELEMELOSZTÁS

EVESMODELL.append B1DOM=XGDP

EVESMODELL.append B1FIRM=XGDP*QSGDPFIRM/QSGDP

'EVESMODELL.append B1GOV=PARAMB1GOV*XGDP

'EVESMODELL.append B1GOVQGDP=PARAMB1GOV*QGDP

'EVESMODELL.append PARAMQGDPGOV=(PARAMB1GOV*QGDP)/(PARAMB1GOV*QGDP)(-1)

'EVESMODELL.append PARAMQGDPGOV=(B1GOVQGDP)/(B1GOVQGDP) $(-1)$

EVESMODELL.append B1NPR=PARAMB1NPR*XGDP

EVESMODELL.append B1HOUS=B1DOM-B1FIRM-B1GOV-B1NPR

EVESMODELL.append B1HOUSQGDP=PARAMB1HOUS*QGDP

EVESMODELL.append B1ROW=XM-XX

EVESMODELL.append D1FIRM=WFIRM*LFIRM*RATEEARNFIRM*(1+RATESSCE)/1000

'EVESMODELL.append D1GOV=PARAMD1GOV*D1DOM

EVESMODELL.append D1NPR=PARAMD1NPR*D1DOM

EVESMODELL.append D1HOUS=D1DOM-D1GOV-D1FIRM-D1NPR

EVESMODELL.append D1ROW=D1ROW 
EVESMODELL.append ADOS=ADOS(-1)+B9GOV

EVESMODELL.append D4ROW=PARAMD4ROW*XGDP

EVESMODELL.append D4DOM=-D4ROW

EVESMODELL.append D4FIRM=D4DOM-D4GOV-D4HOUS

EVESMODELL.append D4GOV=PARAMD4GOV*ADOS(-1)

EVESMODELL.append D4HOUS=PARAMD4HOUS*EARNINGDOM

EVESMODELL.append D2SUM=PARAMD2SUM ${ }^{*} X C P U R$

'EVESMODELL.append D3SUM=PARAMD3SUM*XGDP

EVESMODELL.append B5FIRM=B1FIRM-D1FIRM-D2SUM+D3SUM+D4FIRM

EVESMODELL.append B5GOV=B1GOV-D1GOV+D2SUM-D3SUM+D4GOV

EVESMODELL.append B5NPR=B1NPR-D1NPR+D4NPR

EVESMODELL.append B5HOUS=B1HOUS-D1HOUS+D1DOM+D1ROW+D4HOUS

EVESMODELL.append B5DOM=B1DOM+D4DOM+D1ROW

EVESMODELL.append B5ROW=B1ROW-D1ROW+D4ROW

EVESMODELL.append D5FIRM=PARAMD5FIRM*XGDP

EVESMODELL.append D5HOUS=PARAMD5HOUS*EARNINGDOM

EVESMODELL.append D5SUM=D5FIRM+D5HOUS

EVESMODELL.append D61SUM $=(\text { RATESSCE+RATESSCH) })^{*}$ EARNINGDOM

EVESMODELL.append D61FIRM=RATED61FIRM*D61SUM

EVESMODELL.append D61GOV=(1-RATED61FIRM)*D61SUM

'EVESMODELL.append D62GOV=RATED62GOV*XGDP

EVESMODELL.append D62NPR=RATED62NPR*XGDP

EVESMODELL.append D62FIRM=RATED62FIRM ${ }^{*} X G D P$

EVESMODELL.append D62SUM=D62GOV+D62FIRM+D62NPR

EVESMODELL.append D7ROW=PARAMD7ROW*XGDP-(D7EUINF+D7EUHUM+D7EUPROD)

EVESMODELL.append D7DOM=-D7ROW

EVESMODELL.append D7GOVREV=PARAMD7GOVREV*XGDP+(D7EUINFG+D7EUHUMG+D7EUPRODG)

EVESMODELL.append D7GOV=D7GOVREV-D7GOVEXP

EVESMODELL.append D7FIRM=PARAMD7FIRM*XGDP+(D7EUINFFIRM+D7EUHUMF+D7EUPRODF)

EVESMODELL.append D7HOUS=D7DOM-D7GOV-D7FIRM

EVESMODELL.append D7EUINF=TRANSEU*PARAMTREU*PARD7INF*ERATEEU/1000

EVESMODELL.append D7EUHUM=TRANSEU*PARAMTREU*PARD7HUM*ERATEEU/1000

EVESMODELL.append D7EUPROD=TRANSEU*PARAMTREU*PARD7PROD*ERATEEU/1000

EVESMODELL.append D7EUINFG=D7EUINF*PARD7INFGOV 
EVESMODELL.append D7EUINFFIRM=D7EUINF*PARD7INFFIRM EVESMODELL.append D7EUHUMG=D7EUHUM*PARD7HUMGOV

EVESMODELL.append D7EUHUMF=D7EUHUM*PARD7HUMFIRM EVESMODELL.append D7EUPRODG=D7EUPROD*PARD7PRODGOV EVESMODELL.append D7EUPRODF=D7EUPROD*PARD7PRODFIRM

EVESMODELL.append D7EUINFS=D7EUINF*PARTREUS EVESMODELL.append D7EUHUMS=D7EUHUM*PARTREUS EVESMODELL.append D7EUPRODS=D7EUPROD*PARTREUS EVESMODELL.append D7EUINFGS=D7EUINFG*PARTREUS EVESMODELL.append D7EUINFFIRMS=D7EUINFFIRM*PARTREUS EVESMODELL.append D7EUHUMGS=D7EUHUMG*PARTREUS EVESMODELL.append D7EUHUMFS=D7EUHUMF*PARTREUS EVESMODELL.append D7EUPRODGS=D7EUPRODG*PARTREUS EVESMODELL.append D7EUPRODFS=D7EUPRODF*PARTREUS

EVESMODELL.append B6FIRM=B5FIRM-D5FIRM+D61FIRM-D62FIRM+D7FIRM EVESMODELL.append B6GOV=B5GOV+D5SUM+D61GOV-D62GOV+D7GOV EVESMODELL.append B6NPR=B5NPR-D62NPR+D7NPR EVESMODELL.append B6HOUS=B5HOUS-D5HOUS-D61SUM+D62SUM+D7HOUS EVESMODELL.append B6DOM=B5DOM+D7DOM EVESMODELL.append B6ROW=B5ROW+D7ROW

EVESMODELL.append D63SUM=D63GOV/RATED63GOV

'EVESMODELL.append D63GOV=RATED63GOV*D63SUM

EVESMODELL.append D63NPR=D63SUM-D63GOV

EVESMODELL.append B7FIRM=B6FIRM

EVESMODELL.append B7GOV=B6GOV-D63GOV

EVESMODELL.append B7NPR=B6NPR-D63NPR

EVESMODELL.append B7HOUS=B6HOUS+D63SUM

EVESMODELL.append B7DOM=B6DOM

EVESMODELL.append B7ROW=B6ROW

EVESMODELL.append D8SUM=PARAMD8*D61FIRM

EVESMODELL.append B8FIRM=B7FIRM-D8SUM

EVESMODELL.append B8GOV=B7GOV-XCPUB

EVESMODELL.append B8NPR=B7NPR

EVESMODELL.append B8HOUS=B7HOUS+D8SUM-XCP

EVESMODELL.append B8DOM=B7DOM-XC

EVESMODELL.append B8ROW=B7ROW 
EVESMODELL.append D9ROW=PARAMD9ROW*XGDP-(D9EUINF+D9EUHUM+D9EUPROD)

EVESMODELL.append D9DOM=-D9ROW

EVESMODELL.append D9GOVREV=PARAMD9GOVREV*XGDP+(D9EUINFG+D9EUHUMG+D9EUPRODG)

EVESMODELL.append D9GOV=D9GOVREV-D9GOVEXP

EVESMODELL.append D9FIRM=PARAMD9FIRM*XGDP+(D9EUINFF+D9EUHUMF+D9EUPRODF)

EVESMODELL.append D9HOUS= D9DOM-D9GOV-D9FIRM

EVESMODELL.append D9EUINF=TRANSEU*(1-PARAMTREU)*PARD9INF*ERATEEU/1000

EVESMODELL.append D9EUHUM=TRANSEU*(1-PARAMTREU)*PARD9HUM*ERATEEU/1000

EVESMODELL.append D9EUPROD=TRANSEU*(1-PARAMTREU)*PARD9PROD*ERATEEU/1000

EVESMODELL.append D9EUINFG=D9EUINF*PARD9INFGOV

EVESMODELL.append D9EUINFF=D9EUINF*PARD9INFFIRM

EVESMODELL.append D9EUHUMG=D9EUHUM*PARD9HUMGOV

EVESMODELL.append D9EUHUMF=D9EUHUM*PARD9HUMFIRM

EVESMODELL.append D9EUPRODG=D9EUPROD*PARD9PRODGOV

EVESMODELL.append D9EUPRODF=D9EUPROD*PARD9PRODFIRM

EVESMODELL.append D9EUINFS=D9EUINF*PARTREUS

EVESMODELL.append D9EUHUMS=D9EUHUM ${ }^{*}$ PARTREUS

EVESMODELL.append D9EUPRODS=D9EUPROD*PARTREUS

EVESMODELL.append D9EUINFGS=D9EUINFG*PARTREUS

EVESMODELL.append D9EUINFFS=D9EUINFF*PARTREUS

EVESMODELL.append D9EUHUMGS=D9EUHUMG*PARTREUS

EVESMODELL.append D9EUHUMFS=D9EUHUMF*PARTREUS

EVESMODELL.append D9EUPRODGS=D9EUPRODG*PARTREUS

EVESMODELL.append D9EUPRODFS=D9EUPRODF*PARTREUS

'EVESMODELL.append D9DOM=D9FIRM+D9GOV+D9HOUS

EVESMODELL.append B10FIRM=B8FIRM+D9FIRM

EVESMODELL.append B10GOV=B8GOV+D9GOV

EVESMODELL.append B10NPR=B8NPR

EVESMODELL.append B10HOUS=B8HOUS+D9HOUS

EVESMODELL.append B10DOM=B8DOM+D9DOM

EVESMODELL.append B10ROW=B8ROW+D9ROW

EVESMODELL.append B9FIRM=B10FIRM-XINVBU-XDSTCKFIRM

EVESMODELL.append B9GOV=B10GOV-XINVPU

EVESMODELL.append B9NPR=B10NPR

EVESMODELL.append B9HOUS=B10HOUS-XINVDW-XDSTCKHOUS

EVESMODELL.append B9DOM=B10DOM-XACC

EVESMODELL.append B9ROW=B10ROW 
EVESMODELL.append GOVREVE=B1GOV+D2SUM+D5HOUS+D5FIRM+D61GOV

EVESMODELL.append GOVEXPE=D1GOV+D3SUM-D4GOV+D62GOV+D63GOV-D9GOV+XCPUB+XINVPUD7GOV

EVESMODELL.append GOVBALE=GOVREVE-GOVEXPE

'EVESMODELL.append GOVBAL=B9GOV

'KULFOLD

'EVESMODELL.append B6ROW=XM-XX+D4ROW+D9ROW

'EVESMODELL.append B9ROW=XM-XX+D4ROW+D7ROW+D9ROW

EVESMODELL.append B9ROWEU=B9ROW/ERATEEU/1000

EVESMODELL.append B9ROWDOL=B9ROWEU/CROSS

'EVESMODELL.append CAB=-B6ROW

'EVESMODELL.append CABEU=CAB/ERATEEU/1000

'EVESMODELL.append CABDOL=CABEU/CROSS

'A SZIMULÁCIÓS IDŐSZAK MEGADÁSA

smpl 20092020

'AZ AKTUÁLIS EGYENLETEK SZIMULÁLÁSA

solve EVESMODELL

' AZ EREDMÉNYEK EXPORTÁLÁSA EXCEL FILE-BA

SMPL 19902021

GROUP GROUPMIND *

WRITE(t) d:IEVESMODELLIEVESOUTPUT.WK3 GROUPMIND

WRITE(t) d:IEVESMODELLITUNDI.WK3 QGDPFOR DIHEU QXFOR BOOM QCPFOR QINVFOR QINVBUFOR QINVPUFOR QMFOR XGDPFOR B6ROWFOR ERATEEU LOANRATE GOVREVEFOR GOVEXPEFOR GOVBALEFOR CPIFOR LFOR URATEFOR PRODLFOR WFOR D1DOMFOR B6HOUSFOR/CPIFOR WFOR/CPIFOR B9GOVFOR B9HOUSFOR B9FIRMFOR B9ROWFOR B9NPRFOR ADOSFOR 'group group_tfp tfp tfpfor

'smpl 19992004

'group_tfp.line

'EXIT 


\section{2. sZ. MELLÉKLET}

\section{A modell paraméterrendszere valamint a modell fontosabb egzogén változóinak alakulása}

\begin{tabular}{|c|c|c|c|c|c|c|c|c|c|c|}
\hline & 2011 & 2012 & 2013 & 2014 & 2015 & 2016 & 2017 & 2018 & 2019 & 2020 \\
\hline \multicolumn{11}{|l|}{ GDP keresleti oldala } \\
\hline PARAM11 & 0,700 & 0,700 & 0,700 & 0,700 & 0,700 & 0,700 & 0,700 & 0,700 & 0,700 & 0,700 \\
\hline PARAM12 & $-0,030$ & 0,020 & 0,020 & 0,020 & 0,020 & 0,020 & 0,020 & 0,020 & 0,020 & 0,020 \\
\hline PARAM13 & 0,030 & 0,030 & 0,030 & 0,030 & 0,030 & 0,030 & 0,030 & 0,030 & 0,030 & 0,030 \\
\hline PARAM14 & $-0,600$ & $-0,600$ & $-0,600$ & $-0,600$ & $-0,600$ & $-0,600$ & $-0,600$ & $-0,600$ & $-0,600$ & $-0,600$ \\
\hline A1SUM & 0,012 & 0,023 & 0,030 & 0,030 & 0,030 & 0,030 & 0,030 & 0,030 & 0,030 & 0,030 \\
\hline PARAM21 & 1,267 & 1,267 & 1,267 & 1,267 & 1,267 & 1,267 & 1,267 & 1,267 & 1,267 & 1,267 \\
\hline PARAM22 & 0,322 & 0,322 & 0,322 & 0,322 & 0,322 & 0,322 & 0,322 & 0,322 & 0,322 & 0,322 \\
\hline PARAM23 & 0,240 & 0,240 & 0,240 & 0,240 & 0,240 & 0,240 & 0,240 & 0,240 & 0,240 & 0,240 \\
\hline PARAM24 & $-0,900$ & $-0,900$ & $-0,900$ & $-0,900$ & \begin{tabular}{|c|}
$-0,900$ \\
\end{tabular} & $-0,900$ & $-0,900$ & $-0,900$ & $-0,900$ & $-0,900$ \\
\hline A2SUM & $-0,287$ & $-0,107$ & $-0,097$ & $-0,097$ & $-0,077$ & \begin{tabular}{|c|}
$-0,057$ \\
\end{tabular} & $-0,057$ & $-0,057$ & $-0,057$ & $-0,057$ \\
\hline PARAM31 & 0,040 & 0,040 & 0,040 & 0,040 & 0,040 & 0,040 & 0,040 & 0,040 & 0,040 & 0,040 \\
\hline PARAM41 & 0,100 & 0,070 & 0,040 & 0,040 & 0,040 & 0,040 & 0,040 & 0,040 & 0,040 & 0,040 \\
\hline PARAM51 & 0,800 & 0,800 & 0,800 & 0,800 & 0,800 & 0,800 & 0,800 & 0,800 & 0,800 & 0,800 \\
\hline BOOM & 1,194 & 1,206 & 1,230 & 1,260 & 1,292 & 1,324 & 1,357 & 1,391 & 1,426 & 1,462 \\
\hline PARAM52 & 0,200 & 0,200 & 0,200 & 0,200 & 0,200 & 0,200 & 0,200 & 0,200 & 0,200 & 0,200 \\
\hline PARAM53 & 0,800 & 0,800 & 0,800 & 0,800 & 0,800 & 0,800 & 0,800 & 0,800 & 0,800 & 0,800 \\
\hline PARAM54 & 0,358 & 0,358 & 0,358 & 0,358 & 0,358 & 0,358 & 0,358 & 0,358 & 0,358 & 0,358 \\
\hline A3SUM & 0,033 & 0,070 & 0,070 & 0,050 & 0,060 & 0,060 & 0,060 & 0,060 & 0,060 & 0,060 \\
\hline PARAM61 & 0,203 & 0,203 & 0,203 & 0,203 & 0,203 & 0,203 & 0,203 & 0,203 & 0,203 & 0,203 \\
\hline PARAM62 & 0,056 & 0,056 & 0,056 & 0,056 & 0,056 & 0,056 & 0,056 & 0,056 & 0,056 & 0,056 \\
\hline PARAM63 & 0,683 & 0,683 & 0,683 & 0,683 & 0,683 & 0,683 & 0,683 & 0,683 & 0,683 & 0,683 \\
\hline PARAM64 & 0,198 & 0,198 & 0,198 & 0,198 & 0,198 & 0,198 & 0,198 & 0,198 & 0,198 & 0,198 \\
\hline PARAM65 & $-0,232$ & $-0,232$ & $-0,232$ & $-0,232$ & $-0,232$ & $-0,232$ & $-0,232$ & $-0,232$ & $-0,232$ & $-0,232$ \\
\hline A4SUM & 0,031 & 0,031 & 0,031 & 0,031 & 0,031 & 0,031 & 0,031 & 0,031 & 0,031 & 0,031 \\
\hline RATED63GOV & 0,880 & 0,880 & 0,880 & 0,880 & 0,880 & 0,880 & 0,880 & 0,880 & 0,880 & 0,880 \\
\hline PARAMGDPGOV & 1,060 & 1,060 & 1,060 & 1,060 & 1,060 & 1,060 & 1,060 & 1,060 & 1,060 & 1,060 \\
\hline PARAMQGDPGOV & 1,040 & 1,040 & 1,040 & 1,040 & 1,040 & 1,040 & 1,040 & 1,040 & 1,040 & 1,040 \\
\hline PARAMGDPHOUS & 0,230 & 0,230 & 0,230 & 0,230 & 0,230 & 0,230 & 0,230 & 0,230 & 0,230 & 0,230 \\
\hline PARAMQGDPHOUS & 0,268 & 0,268 & 0,268 & 0,268 & 0,268 & 0,268 & 0,268 & 0,268 & 0,268 & 0,268 \\
\hline AMORT & 0,040 & 0,040 & 0,040 & 0,040 & 0,040 & 0,040 & 0,040 & 0,040 & 0,040 & 0,040 \\
\hline XGDP_AD & 0,000 & 0,000 & 0,000 & 0,000 & 0,000 & 0,000 & 0,000 & 0,000 & 0,000 & 0,000 \\
\hline TFP & 2,416 & 2,452 & 2,489 & 2,527 & 2,564 & 2,603 & 2,642 & 2,682 & 2,722 & 2,763 \\
\hline par_tfp_01d & 0,100 & 0,100 & 0,100 & 0,100 & 0,100 & 0,100 & 0,100 & 0,100 & 0,100 & 0,100 \\
\hline par_tfp_01e & 0,100 & 0,100 & 0,100 & 0,100 & 0,100 & 0,100 & 0,100 & 0,100 & 0,100 & 0,100 \\
\hline par_tfp_04 & 0,116 & 0,116 & 0,116 & 0,116 & 0,116 & 0,116 & 0,116 & 0,116 & 0,116 & 0,116 \\
\hline par_tfp_05 & 0,116 & 0,116 & 0,116 & 0,116 & 0,116 & 0,116 & 0,116 & 0,116 & 0,116 & 0,116 \\
\hline par_tfp_D9 & 0,063 & 0,063 & 0,063 & 0,063 & 0,063 & 0,063 & 0,063 & 0,063 & 0,063 & 0,063 \\
\hline par_tfp_qinvpu & 0,088 & 0,088 & 0,088 & 0,088 & 0,088 & 0,088 & 0,088 & 0,088 & 0,088 & 0,088 \\
\hline par_tfp & 0,004 & 0,004 & 0,004 & 0,004 & 0,004 & 0,004 & 0,004 & 0,004 & 0,004 & 0,004 \\
\hline GAMMA & 0,800 & 0,800 & 0,800 & 0,800 & 0,800 & 0,800 & 0,800 & 0,800 & 0,800 & 0,800 \\
\hline ALFA & 0,300 & 0,300 & 0,300 & 0,300 & 0,300 & 0,300 & 0,300 & 0,300 & 0,300 & 0,300 \\
\hline \multicolumn{11}{|l|}{ Árak-Bérek } \\
\hline ERATEEU & 279 & 290 & 280 & 280 & 280 & 280 & 280 & 280 & 280 & 280 \\
\hline EUINDEX & 1,126 & 1,169 & 1,129 & 1,129 & 1,129 & 1,129 & 1,129 & 1,129 & 1,129 & 1,129 \\
\hline ERATEDOL & 233 & 242 & 233 & 233 & 233 & 233 & 233 & 233 & 233 & 233 \\
\hline DOLINDEX & 1,079 & 1,120 & 1,082 & 1,082 & 1,082 & 1,082 & 1,082 & 1,082 & 1,082 & 1,082 \\
\hline DEVAL & 124 & 128 & 124 & 124 & 124 & 124 & 124 & 124 & 124 & 124 \\
\hline CROSS & 1,2 & 1,2 & 1,2 & 1,2 & 1,2 & 1,2 & 1,2 & 1,2 & 1,2 & 1,2 \\
\hline WPIIMPEU & 169 & 172 & 175 & 177 & 180 & 183 & 185 & 188 & 191 & 194 \\
\hline WPIEXPEU & 165 & 169 & 171 & 174 & 176 & 179 & 182 & 184 & 187 & 190 \\
\hline CPIEXPECT & 1,352 & 1,417 & 1,459 & 1,503 & 1,548 & 1,591 & 1,634 & 1,683 & 1,732 & 1,777 \\
\hline PARAM71 & 0,033 & 0,033 & 0,033 & 0,033 & 0,033 & 0,033 & 0,033 & 0,033 & 0,033 & 0,033 \\
\hline PARAM72 & 0,360 & 0,360 & 0,360 & 0,360 & 0,360 & 0,360 & 0,360 & 0,360 & 0,360 & 0,360 \\
\hline PARAM73 & 0,804 & 0,804 & 0,804 & 0,804 & 0,804 & 0,804 & 0,804 & 0,804 & 0,804 & 0,804 \\
\hline A5SUM & \begin{tabular}{ll|}
$-0,022$ \\
\end{tabular} & \begin{tabular}{l|l|}
$-0,022$ \\
\end{tabular} & $-0,022$ & $-0,022$ & $-0,022$ & \begin{tabular}{ll|}
$-0,022$ \\
\end{tabular} & $-0,022$ & $-0,022$ & $-0,022$ & $-0,022$ \\
\hline PARAM81 & 0,030 & 0,030 & 0,030 & 0,030 & 0,030 & 0,030 & 0,030 & 0,030 & 0,030 & 0,030 \\
\hline PARAM82 & 0,042 & 0,050 & 0,035 & 0,025 & 0,020 & 0,020 & 0,020 & 0,020 & 0,020 & 0,020 \\
\hline PARAM83 & 0,040 & 0,040 & 0,040 & 0,040 & 0,040 & 0,040 & 0,040 & 0,040 & 0,040 & 0,040 \\
\hline PARAM84 & 0,785 & 0,785 & 0,785 & 0,785 & 0,785 & 0,785 & 0,785 & 0,785 & 0,785 & 0,785 \\
\hline
\end{tabular}




\begin{tabular}{|c|c|c|c|c|c|c|c|c|c|c|}
\hline & 2011 & 2012 & 2013 & 2014 & 2015 & 2016 & 2017 & 2018 & 2019 & 2020 \\
\hline PARAM85 & 0,030 & 0,030 & 0,030 & 0,030 & 0,030 & 0,030 & 0,030 & 0,030 & 0,030 & 0,030 \\
\hline PARAM86 & $-0,010$ & $-0,010$ & $-0,010$ & $-0,010$ & $-0,010$ & $-0,010$ & $-0,010$ & $-0,010$ & $-0,010$ & $-0,010$ \\
\hline PARAM87 & $-0,013$ & $-0,013$ & $-0,013$ & $-0,013$ & $-0,013$ & $-0,013$ & $-0,013$ & $-0,013$ & $-0,013$ & $-0,013$ \\
\hline A6SUM & 0,001 & $-0,001$ & 0,000 & 0,000 & 0,000 & 0,000 & 0,000 & 0,000 & 0,000 & 0,000 \\
\hline PARAMPRODL & 0,040 & 0,040 & 0,040 & 0,040 & 0,040 & 0,040 & 0,040 & 0,040 & 0,040 & 0,040 \\
\hline PARAM91 & 0,900 & 0,900 & 0,900 & 0,900 & 0,900 & 0,900 & 0,900 & 0,900 & 0,900 & 0,900 \\
\hline PARAM92 & 0,050 & 0,050 & 0,050 & 0,050 & 0,050 & 0,050 & 0,050 & 0,050 & 0,050 & 0,050 \\
\hline PARAM93 & $-0,670$ & $-0,670$ & $-0,670$ & $-0,670$ & $-0,670$ & $-0,670$ & $-0,670$ & $-0,670$ & $-0,670$ & $-0,670$ \\
\hline PARAM94 & 0,971 & 0,971 & 0,971 & 0,971 & 0,971 & 0,971 & 0,971 & 0,971 & 0,971 & 0,971 \\
\hline PARAMB1TAX & 0,140 & 0,140 & 0,140 & 0,140 & 0,140 & 0,140 & 0,140 & 0,140 & 0,140 & 0,140 \\
\hline PARAM96 & 0,023 & 0,023 & 0,023 & 0,023 & 0,023 & 0,023 & 0,023 & 0,023 & 0,023 & 0,023 \\
\hline PARAM97 & 0,014 & 0,014 & 0,014 & 0,014 & 0,014 & 0,014 & 0,014 & 0,014 & 0,014 & 0,014 \\
\hline A7SUM & 0,081 & 0,070 & 0,080 & 0,080 & 0,080 & 0,080 & 0,080 & 0,080 & 0,080 & 0,080 \\
\hline A8SUM & 1,330 & 1,345 & 1,345 & 1,340 & 1,335 & 1,335 & 1,335 & 1,335 & 1,335 & 1,330 \\
\hline \multicolumn{11}{|l|}{ Jövedelemelosztás } \\
\hline PARAMB1FIRM & 0,670 & 0,670 & 0,670 & 0,670 & 0,670 & 0,670 & 0,670 & 0,670 & 0,670 & 0,670 \\
\hline PARAMB1HOUS & 0,150 & 0,150 & 0,150 & 0,150 & 0,150 & 0,150 & 0,150 & 0,150 & 0,150 & 0,150 \\
\hline PARAMB1NPR & 0,009 & 0,009 & 0,009 & 0,009 & 0,009 & 0,009 & 0,009 & 0,009 & 0,009 & 0,009 \\
\hline PARAMB1GOV & 0,171 & 0,171 & 0,171 & 0,171 & 0,171 & 0,171 & 0,171 & 0,171 & 0,171 & 0,171 \\
\hline PARAMD1FIRM & 0,690 & 0,690 & 0,700 & 0,700 & 0,700 & 0,700 & 0,700 & 0,700 & 0,700 & 0,700 \\
\hline PARAMD1GOV & 0,260 & 0,260 & 0,250 & 0,250 & 0,250 & 0,250 & 0,250 & 0,250 & 0,250 & 0,250 \\
\hline PARAMD1NPR & 0,012 & 0,012 & 0,012 & 0,012 & 0,012 & 0,012 & 0,012 & 0,012 & 0,012 & 0,012 \\
\hline PARAMB2B3 & 0,320 & 0,320 & 0,320 & 0,320 & 0,320 & 0,320 & 0,320 & 0,320 & 0,320 & 0,320 \\
\hline PARAMD2SUM & 0,296 & 0,296 & 0,296 & 0,296 & 0,296 & 0,296 & 0,296 & 0,296 & 0,296 & 0,296 \\
\hline PARAMD3SUM & 0,020 & 0,020 & 0,020 & 0,020 & 0,020 & 0,020 & 0,020 & 0,020 & 0,020 & 0,020 \\
\hline PARAMD4HOUS & 0,120 & 0,110 & 0,120 & 0,120 & 0,120 & 0,120 & 0,120 & 0,120 & 0,120 & 0,120 \\
\hline PARAMD4GOV & 0,040 & 0,040 & 0,040 & 0,040 & 0,040 & 0,040 & 0,040 & 0,040 & 0,040 & 0,040 \\
\hline PARAMD5FIRM & 0,030 & 0,030 & 0,025 & 0,025 & 0,025 & 0,025 & 0,025 & 0,020 & 0,020 & 0,020 \\
\hline PARAMD5HOUS & 0,200 & 0,200 & 0,200 & 0,200 & 0,200 & 0,200 & 0,200 & 0,200 & 0,200 & 0,200 \\
\hline PARAMD63 & 0,160 & 0,160 & 0,160 & 0,160 & 0,160 & 0,160 & 0,160 & 0,160 & 0,160 & 0,160 \\
\hline RATESSCE & 0,290 & 0,290 & 0,290 & 0,290 & 0,290 & 0,290 & 0,290 & 0,290 & 0,290 & 0,290 \\
\hline RATESSCH & 0,085 & 0,085 & 0,085 & 0,085 & 0,085 & 0,085 & 0,085 & 0,085 & 0,085 & 0,085 \\
\hline RATED61FIRM & 0,145 & 0,145 & 0,145 & 0,145 & 0,145 & 0,145 & 0,145 & 0,145 & 0,145 & 0,145 \\
\hline RATED62FIRM & 0,002 & 0,002 & 0,002 & 0,002 & 0,002 & 0,002 & 0,002 & 0,002 & 0,002 & 0,002 \\
\hline RATED62GOV & 0,135 & 0,135 & 0,135 & 0,135 & 0,135 & 0,135 & 0,135 & 0,135 & 0,135 & 0,135 \\
\hline RATED62NPR & 0,002 & 0,002 & 0,002 & 0,002 & 0,002 & 0,002 & 0,002 & 0,002 & 0,002 & 0,002 \\
\hline PARAMD7GOVREV & 0,006 & 0,006 & 0,006 & 0,006 & 0,006 & 0,006 & 0,006 & 0,006 & 0,006 & 0,006 \\
\hline PARAMD7FIRM & $-0,004$ & $-0,004$ & $-0,004$ & $-0,004$ & $-0,004$ & $-0,004$ & $-0,004$ & $-0,004$ & $-0,004$ & $-0,004$ \\
\hline PARAMD8 & 0,723 & 0,723 & 0,723 & 0,723 & 0,723 & 0,723 & 0,723 & 0,723 & 0,723 & 0,723 \\
\hline PARAMD9FIRM & 0,011 & 0,011 & 0,011 & 0,011 & 0,011 & 0,011 & 0,011 & 0,011 & 0,011 & 0,011 \\
\hline PARAMD9GOVREV & 0,005 & 0,005 & 0,005 & 0,005 & 0,005 & 0,005 & 0,005 & 0,005 & 0,005 & 0,005 \\
\hline PARAMXCPUB & 0,098 & 0,098 & 0,098 & 0,098 & 0,098 & 0,098 & 0,098 & 0,098 & 0,098 & 0,098 \\
\hline PARAMW & 0,370 & 0,370 & 0,370 & 0,370 & 0,370 & 0,370 & 0,370 & 0,370 & 0,370 & 0,370 \\
\hline PARAMXDSTCKFIRM & 0,976 & 0,976 & 0,976 & 0,976 & 0,976 & 0,976 & 0,976 & 0,976 & 0,976 & 0,976 \\
\hline PARAMXINVDWHOUS & 0,960 & 0,960 & 0,960 & 0,960 & 0,960 & 0,960 & 0,960 & 0,960 & 0,960 & 0,960 \\
\hline K2HOUS & 0,000 & 0,000 & 0,000 & 0,000 & 0,000 & 0,000 & 0,000 & 0,000 & 0,000 & 0,000 \\
\hline PARAMD4ROW & 0,072 & 0,072 & 0,072 & 0,072 & 0,072 & 0,072 & 0,072 & 0,072 & 0,072 & 0,072 \\
\hline DIHEU & 1450 & 1595 & 1755 & 1930 & 2123 & 2335 & 2569 & 2826 & 3108 & 3419 \\
\hline TRANSEU & 3350 & 3300 & 3500 & 3900 & 3800 & 3700 & 3600 & 3600 & 3600 & 3600 \\
\hline PARAMTREU & 0,250 & 0,250 & 0,250 & 0,250 & 0,250 & 0,250 & 0,250 & 0,250 & 0,250 & 0,250 \\
\hline PARAMD7ROW & 0,003 & 0,003 & 0,003 & 0,003 & 0,003 & 0,003 & 0,003 & 0,003 & 0,003 & 0,003 \\
\hline PARAMD9ROW & $-0,006$ & $-0,006$ & $-0,006$ & $-0,006$ & $-0,006$ & $-0,006$ & $-0,006$ & $-0,006$ & $-0,006$ & $-0,006$ \\
\hline PARD7INF & 0,001 & 0,001 & 0,001 & 0,001 & 0,001 & 0,001 & 0,001 & 0,001 & 0,001 & 0,001 \\
\hline PARD7HUM & 0,600 & 0,600 & 0,600 & 0,600 & 0,600 & 0,600 & 0,600 & 0,600 & 0,600 & 0,600 \\
\hline PARD7PROD & 0,399 & 0,399 & 0,399 & 0,399 & 0,399 & 0,399 & 0,399 & 0,399 & 0,399 & 0,399 \\
\hline PARD7INFGOV & 0,000 & 0,000 & 0,000 & 0,000 & 0,000 & 0,000 & 0,000 & 0,000 & 0,000 & 0,000 \\
\hline
\end{tabular}




\begin{tabular}{|c|c|c|c|c|c|c|c|c|c|c|}
\hline & 2011 & 2012 & 2013 & 2014 & 2015 & 2016 & 2017 & 2018 & 2019 & 2020 \\
\hline PARD7INFFIRM & 1,000 & 1,000 & 1,000 & 1,000 & 1,000 & 1,000 & 1,000 & 1,000 & 1,000 & 1,000 \\
\hline PARD7HUMGOV & 0,000 & 0,000 & 0,000 & 0,000 & 0,000 & 0,000 & 0,000 & 0,000 & 0,000 & 0,000 \\
\hline PARD7HUMFIRM & 1,000 & 1,000 & 1,000 & 1,000 & 1,000 & 1,000 & 1,000 & 1,000 & 1,000 & 1,000 \\
\hline PARD7PRODGOV & 0,000 & 0,000 & 0,000 & 0,000 & 0,000 & 0,000 & 0,000 & 0,000 & 0,000 & 0,000 \\
\hline PARD7PRODFIRM & 1,000 & 1,000 & 1,000 & 1,000 & 1,000 & 1,000 & 1,000 & 1,000 & 1,000 & 1,000 \\
\hline PARD9INF & 0,630 & 0,630 & 0,630 & 0,630 & 0,630 & 0,630 & 0,630 & 0,630 & 0,630 & 0,630 \\
\hline PARD9HUM & 0,170 & 0,170 & 0,170 & 0,170 & 0,170 & 0,170 & 0,170 & 0,170 & 0,170 & 0,170 \\
\hline PARD9PROD & 0,200 & 0,200 & 0,200 & 0,200 & 0,200 & 0,200 & 0,200 & 0,200 & 0,200 & 0,200 \\
\hline PARD9INFGOV & 1,000 & 1,000 & 1,000 & 1,000 & 1,000 & 1,000 & 1,000 & 1,000 & 1,000 & 1,000 \\
\hline PARD9INFFIRM & 0,000 & 0,000 & 0,000 & 0,000 & 0,000 & 0,000 & 0,000 & 0,000 & 0,000 & 0,000 \\
\hline PARD9HUMGOV & 0,500 & 0,500 & 0,500 & 0,500 & 0,500 & 0,500 & 0,500 & 0,500 & 0,500 & 0,500 \\
\hline PARD9HUMFIRM & 0,500 & 0,500 & 0,500 & 0,500 & 0,500 & 0,500 & 0,500 & 0,500 & 0,500 & 0,500 \\
\hline PARD9PRODGOV & 0,000 & 0,000 & 0,000 & 0,000 & 0,000 & 0,000 & 0,000 & 0,000 & 0,000 & 0,000 \\
\hline PARD9PRODFIRM & 1,000 & 1,000 & 1,000 & 1,000 & 1,000 & 1,000 & 1,000 & 1,000 & 1,000 & 1,000 \\
\hline PARTREUS & 0,200 & 0,200 & 0,200 & 0,300 & 0,450 & 0,550 & 0,667 & 0,667 & 0,667 & 0,667 \\
\hline LOANRATE & 0,086 & 0,090 & 0,085 & 0,075 & 0,070 & 0,060 & 0,060 & 0,060 & 0,060 & 0,060 \\
\hline DEPORATE & 0,059 & 0,065 & 0,065 & 0,055 & 0,050 & 0,040 & 0,040 & 0,040 & 0,040 & 0,040 \\
\hline LGOV & 841 & 800 & 800 & 800 & 800 & 800 & 800 & 800 & 800 & 800 \\
\hline QTERM & 2563 & 2537 & 2537 & 2588 & 2640 & 2692 & 2746 & 2801 & 2857 & 2914 \\
\hline PARF01 & 0,111 & 0,111 & 0,111 & 0,111 & 0,111 & 0,111 & 0,111 & 0,111 & 0,111 & 0,111 \\
\hline PARF01D & 0,012 & 0,012 & 0,012 & 0,012 & 0,012 & 0,012 & 0,012 & 0,012 & 0,012 & 0,012 \\
\hline PARF01E & 0,002 & 0,002 & 0,002 & 0,002 & 0,002 & 0,002 & 0,002 & 0,002 & 0,002 & 0,002 \\
\hline PARF02 & 0,029 & 0,029 & 0,029 & 0,029 & 0,029 & 0,029 & 0,029 & 0,029 & 0,029 & 0,029 \\
\hline PARF03 & 0,046 & 0,046 & 0,046 & 0,046 & 0,046 & 0,046 & 0,046 & 0,046 & 0,046 & 0,046 \\
\hline PARF04 & 0,127 & 0,127 & 0,127 & 0,127 & 0,127 & 0,127 & 0,127 & 0,127 & 0,127 & 0,127 \\
\hline PARF05 & 0,120 & 0,120 & 0,120 & 0,120 & 0,120 & 0,120 & 0,120 & 0,120 & 0,120 & 0,120 \\
\hline PARF06 & 0,364 & 0,364 & 0,364 & 0,364 & 0,364 & 0,364 & 0,364 & 0,364 & 0,364 & 0,364 \\
\hline PARF07 & 0,019 & 0,019 & 0,019 & 0,019 & 0,019 & 0,019 & 0,019 & 0,019 & 0,019 & 0,019 \\
\hline PARF08 & 0,040 & 0,040 & 0,040 & 0,040 & 0,040 & 0,040 & 0,040 & 0,040 & 0,040 & 0,040 \\
\hline PARF09 & 0,127 & 0,127 & 0,127 & 0,127 & 0,127 & 0,127 & 0,127 & 0,127 & 0,127 & 0,127 \\
\hline PARF14 & 0,018 & 0,018 & 0,018 & 0,018 & 0,018 & 0,018 & 0,018 & 0,018 & 0,018 & 0,018 \\
\hline GOVEXP & 10048 & 10450 & 10764 & 11356 & 11810 & 12400 & 13082 & 13867 & 14561 & 15362 \\
\hline CPIXCGOV & 1,302 & 1,348 & 1,395 & 1,444 & 1,494 & 1,547 & 1,601 & 1,657 & 1,715 & 1,775 \\
\hline CPIB1GOV & 1,223 & 1,272 & 1,323 & 1,376 & 1,431 & 1,488 & 1,548 & 1,609 & 1,674 & 1,741 \\
\hline FUN01FOR & 1111 & 1155 & 1190 & 1255 & 1306 & 1371 & 1446 & 1533 & 1610 & 1698 \\
\hline
\end{tabular}




\section{3. sz. MELLÉKLET}

A modell által alkalmazott adatrendszer

\begin{tabular}{|c|c|c|c|c|c|c|c|c|c|c|}
\hline & & 2005 & 2006 & 2007 & 2008 & 2009 & 2010 & 2011 & 2012 & 2013 \\
\hline \multicolumn{11}{|c|}{ Bruttó hazai termék 1995-ös áron } \\
\hline Teljes lakossági fogyasztás & qep & 14886,74 & 15169,79 & 15022,54 & 14994,51 & 14134,24 & 13757,37 & 13787,09 & 13698,85 & 13771,88 \\
\hline Vásárolt fogyasztás & qcpur & 11740,90 & 11966,39 & 12089,20 & 12021,62 & 11250,48 & 11012,01 & 11014,49 & 11001,12 & 11014,70 \\
\hline Természetbeni társadalmi juttatások & qterm & 3145,84 & 3203,39 & 2933,69 & 2972,79 & 2882,13 & 2744,45 & 2772,20 & 2695,47 & 2756,49 \\
\hline Önfogyasztás & qonf & 0,00 & 0,00 & $-0,34$ & 0,10 & 1,64 & 0,91 & 0,41 & 2,27 & 0,69 \\
\hline Közösségi fogyasztás & qcpub & 2193,06 & 2282,88 & 2187,46 & 2182,33 & 2239,53 & 2265,09 & 2210,14 & 2210,08 & 2235,28 \\
\hline Összes végső fogyasztás & $\mathrm{qc}$ & 17079,79 & 17452,67 & 17207,01 & 17173,82 & 16378,80 & 16027,06 & 16001,62 & 15913,11 & 16011,65 \\
\hline Állóeszköz-felhalmozás & qinv & 5015,30 & 4882,20 & 5069,93 & 5217,92 & 4645,01 & 4195,98 & 3966,40 & 3877,02 & 3967,48 \\
\hline Vállalkozás & qinvbu & 2987,44 & 2885,02 & 3023,10 & 3271,80 & 2779,96 & 2479,22 & 2388,65 & 2308,54 & 2344,21 \\
\hline Költségvetési és társ.bizt. szervezet & qinvpu & 873,04 & 1008,20 & 853,68 & 697,54 & 703,72 & 783,20 & 686,35 & 702,37 & 740,55 \\
\hline Egyéni (nem piaci) gazd. tevékenység & qinvdw & 1154,82 & 988,97 & 1193,15 & 1248,59 & 1161,34 & 933,56 & 891,39 & 866,11 & 882,72 \\
\hline Készlet felhalmozás & qdstck & 387,10 & 504,35 & 234,46 & 282,63 & $-761,44$ & $-65,35$ & 66,34 & $-36,28$ & 64,29 \\
\hline Bruttó felhalmozás & qacc & 5402,40 & 5386,55 & 5304,39 & 5500,56 & 3883,58 & 4130,63 & 4032,74 & 3840,73 & 4031,77 \\
\hline Belföldi felhasználás & qbelf & 22482,19 & 22839,22 & 22511,31 & 22666,14 & 20289,22 & 20178,91 & 20059,06 & 19762,79 & 20068,26 \\
\hline Export & $q x$ & 14520,42 & 17287,56 & 19874,41 & 21001,03 & 18852,79 & 21547,76 & 23355,32 & 23586,20 & 23355,32 \\
\hline Import & qm & 14984,33 & 17250,41 & 19458,78 & 20522,64 & 17491,58 & 19732,00 & 20978,21 & 20970,86 & 20978,21 \\
\hline Végső felhasználás & qdf & 37002,61 & 40126,78 & 42385,72 & 43667,17 & 39142,01 & 41726,67 & 43414,37 & 43349,00 & 43423,58 \\
\hline GDP & qgdp & 22018,28 & 22876,37 & 22902,61 & 23107,39 & 21536,41 & 21807,37 & 22167,03 & 22068,90 & 22176,33 \\
\hline Potenciális kibocsátás & qsgdp & 22018,28 & 22876,37 & 22902,61 & 23107,39 & 21536,41 & 21807,37 & 22167,03 & 22068,90 & 22176,33 \\
\hline Kapacitáskihasználtság & ut & 0,82 & 0,83 & 0,82 & 0,81 & 0,71 & 0,73 & 0,73 & 0,73 & 0,73 \\
\hline Töke & $q k$ & 39522,818 & 41063,088 & 41110,185 & 41477,772 & 38657,854 & 39144,229 & 39789,819 & 39613,674 & 39806,520 \\
\hline $\operatorname{KFIRM}(2000)$ & kfirm & 41997 & 42752 & 43522 & 44305 & 45103 & 45915 & 46741 & 47583 & 48439 \\
\hline \multirow[t]{3}{*}{ LFIRM } & & 3095,5 & 3141,8 & 3177,4 & 3157,4 & 3034,0 & 3008,7 & 3077,4 & 3141,3 & 3146,6 \\
\hline & & 0,085 & 0,085 & 0,122 & 0,118 & 0,180 & 0,096 & 0,085 & 0,102 & 0,095 \\
\hline & QSGDPGOV & 3448,9 & 3503,3 & 3399,2 & 3415,0 & 3218,4 & 3117,6 & 3018,6 & 2891,6 & 0,0 \\
\hline QSGDPFIRM & qsgdpfirm & 11537 & 12408 & 12427 & 12527 & 11547 & 11971 & & & \\
\hline \multirow[t]{2}{*}{ Cobb-Douglas } & & 6768 & 6876 & 6967 & 6974 & 6818 & 6815 & & & \\
\hline & TFP & 1,7045534 & 1,8046822 & 1,7836364 & 1,7962749 & 1,694 & 1,757 & & & \\
\hline Teljes lakossági fogyasztás & $\mathrm{xcp}$ & 14886,74 & 15702,45 & 16650,59 & 17501,18 & 17087,43 & 17236,43 & 17896,00 & 18257,63 & 17887,40 \\
\hline Vásárolt fogyasztás & xcpur & 11740,90 & 12369,76 & 13363,62 & 13985,46 & 13568,29 & 13854,21 & 14470,67 & 14866,94 & 14485,12 \\
\hline Természetbeni társadalmi juttatások & xterm & 3145,84 & 3332,69 & 3286,97 & 3515,72 & 3519,14 & 3382,22 & 3425,33 & 3390,69 & 3402,28 \\
\hline Önfogyasztás & xonf & 0,0000 & 0,0000 & 0,0000 & 0,0000 & 0,0000 & 0,0000 & 0,0000 & 0,0000 & 0,0000 \\
\hline Közösségi fogyasztás & xcpub & 2193,05 & 2474,64 & 2512,53 & 2674,49 & 2695,81 & 2849,87 & 2822,18 & 2862,09 & 2825,50 \\
\hline Összes végső fogyasztás & $\mathrm{xc}$ & 17079,79 & 18177,09 & 19163,12 & 20175,67 & 19783,24 & 20086,31 & 20718,18 & 21119,71 & 20712,90 \\
\hline Állóeszköz-felhalmozás & xinv & 5015,30 & 5148,03 & 5444,19 & 5759,99 & 5295,20 & 4806,33 & 4709,85 & 4677,26 & 4715,63 \\
\hline Vállalkozás & xinvbu & 2987,44 & 3042,11 & 3246,27 & 3611,69 & 3169,08 & 2839,86 & 2836,37 & 2785,05 & 2786,26 \\
\hline Költségvetési és társ.bizt. szervezet & xinvpu & 873,04 & 1063,10 & 916,70 & 770,00 & 802,22 & 897,12 & 815,00 & 847,32 & 880,19 \\
\hline Egyéni (nem piaci) gazd. tevékenység & xinvdw & 1154,82 & 1042,82 & 1281,23 & 1378,30 & 1323,90 & 1069,36 & 1058,48 & 1044,88 & 1049,18 \\
\hline Készlet felhalmozás & xdstck & 387,10 & 567,35 & 161,74 & 489,42 & $-700,35$ & 116,08 & 581,01 & 629,21 & 654,50 \\
\hline Bruttó felhalmozás & xacc & 5402,40 & 5715,38 & 5605,93 & 6249,41 & 4594,85 & 4922,41 & 5290,86 & 5306,47 & 5370,12 \\
\hline Belföldi felhasználás & xbelf & 22482,19 & 23892,47 & 24769,05 & 26425,07 & 24378,09 & 25008,72 & 26009,04 & 26426,18 & 26083,02 \\
\hline Export & $\mathrm{xx}$ & 14520,42 & 18406,59 & 20319,51 & 21677,13 & 19880,96 & 23148,78 & 25976,76 & 27145,70 & 25976,76 \\
\hline Import & $\mathrm{xm}$ & 14984,33 & 18623,22 & 20096,71 & 21556,56 & 18636,18 & 21409,83 & 23905,47 & 24979,20 & 23905,47 \\
\hline Végső felhasználás & $\mathrm{xdf}$ & 37002,61 & 42299,06 & 45088,56 & 48102,21 & 44259,05 & 48157,50 & 51985,79 & 53571,88 & 52059,78 \\
\hline GDP & xgdp & 22018,28 & 23675,85 & 24991,85 & 26545,65 & 25622,87 & 26747,66 & 28080,32 & 29184,14 & 29405,07 \\
\hline
\end{tabular}




\begin{tabular}{|c|c|c|c|c|c|c|c|c|c|c|}
\hline & & 2005 & 2006 & 2007 & 2008 & 2009 & 2010 & 2011 & 2012 & 2013 \\
\hline \multicolumn{11}{|l|}{ Árak-Bérek } \\
\hline Teljes import árindex (Ft) & pimp & 1,00 & 1,08 & 1,03 & 1,05 & 1,07 & 1,09 & 1,14 & 1,19 & 1,14 \\
\hline Teljes export árindex $(\mathrm{Ft})$ & pexp & 1,00 & 1,06 & 1,02 & 1,03 & 1,05 & 1,07 & 1,11 & 1,15 & 1,11 \\
\hline Termelöi árindex(Ft) & ppiFt & 1,15 & 1,22 & 1,22 & 1,28 & 1,34 & 1,40 & 1,46 & 1,51 & 1,46 \\
\hline Beruházási árindex & pinv & 1,00 & 1,05 & 1,07 & 1,10 & 1,14 & 1,15 & 1,19 & 1,21 & 1,19 \\
\hline Fogyasztói árváltozás & cpi & 1,00 & 1,04 & 1,12 & 1,19 & 1,24 & 1,30 & 1,35 & 1,39 & 1,35 \\
\hline Hitelkamatok & LOANRATE & 0,085 & 0,081 & 0,091 & 0,102 & 0,110 & 0,076 & 0,083 & 0,094 & 0,076 \\
\hline Betéti kamatok & DEPORATE & 0,064 & 0,060 & 0,072 & 0,081 & 0,081 & 0,049 & 0,055 & 0,071 & 0,049 \\
\hline Nominál átlagkereset & W & 1900,37 & 2056,56 & 2220,89 & 2385,77 & 2398,24 & 2430,81 & 2557,11 & 2454,48 & 2384,99 \\
\hline Nominál átlagkereset, költségvetés & WGOV & 2186,22 & 2327,39 & 2474,70 & 2628,53 & 2419,58 & 2351,76 & 2431,72 & 2480,35 & 2554,76 \\
\hline Nominál átlagkereset, versenyszféra & WFIRM & 1782,66 & 1950,37 & 2128,98 & 2304,53 & 2403,65 & 2482,36 & 2482,36 & 2482,36 & 2482,36 \\
\hline \multirow[t]{5}{*}{ Bérek és keresetek } & EARNINGDOM & 8130,09 & 8717,60 & 9247,58 & 9690,10 & 9485,74 & 9593,13 & 10030,10 & 10030,10 & 10030,10 \\
\hline & rateearn & 1,097 & 1,079 & 1,061 & 1,047 & 1,046 & 1,044 & 1,350 & 1,400 & 1,400 \\
\hline & rateearngov & 1,22 & 1,23 & 1,23 & 1,26 & 1,28 & 1,29 & 1,292 & 1,292 & 1,292 \\
\hline & rateearnfirm & 0,96 & 0,93 & 0,92 & 0,91 & 0,88 & 0,87 & 0,869 & 0,869 & 0,869 \\
\hline & ratessce & 0,29 & 0,28 & 0,29 & 0,29 & 0,27 & 0,24 & 0,24 & 0,27 & 0,27 \\
\hline A munkáltatók tb. hozzájárulása & SSCEDOM & 2338,28 & 2467,66 & 2647,86 & 2831,23 & 2607,29 & 2321,59 & 2353,30 & 2353,30 & 2353,30 \\
\hline \multirow[t]{2}{*}{ Munkavállalói jövedelem } & D1DOM & 10468,37 & 11185,26 & 11895,43 & 12521,33 & 12093,03 & 11914,72 & 12383,40 & 12383,40 & 12383,40 \\
\hline & CPITERM & 1,00 & 1,04 & 1,12 & 1,18 & 1,22 & 1,23 & 1,28 & 1,32 & 1,37 \\
\hline \multicolumn{11}{|l|}{ Munkaeröpiac } \\
\hline Munkaerő-kínálat & SL & 4205,38 & 4246,85 & 4238,18 & 4208,58 & 4202,58 & 4255,98 & 4279,85 & 4261,22 & 4242,94 \\
\hline \multirow[t]{2}{*}{ Munkaerö-kereslet } & $\mathrm{L}$ & 3901,53 & 3930,05 & 3926,20 & 3879,43 & 3781,88 & 3781,25 & 3811,95 & 3841,30 & 3826,60 \\
\hline & LFIRM & 3095,53 & 3141,75 & 3177,40 & 3157,43 & 3033,98 & 3008,65 & 3077,35 & 3141,30 & 3146,60 \\
\hline LNOV & LNOV & 0,00 & $-0,01$ & 0,00 & 0,01 & 0,03 & 0,00 & & & \\
\hline Munkanélküliek száma & $\mathrm{U}$ & 303,85 & 316,80 & 311,98 & 329,15 & 420,70 & 474,73 & 467,88 & 419,92 & 416,34 \\
\hline Munkanélküliségi ráta & URATE & 0,07 & 0,07 & 0,07 & 0,08 & 0,10 & 0,11 & 0,11 & 0,11 & 0,11 \\
\hline Termelékenység & PRODL & 5,64 & 5,82 & 5,83 & 5,96 & 5,69 & 5,77 & 5,82 & 5,75 & 5,80 \\
\hline
\end{tabular}




\begin{tabular}{|c|c|c|c|c|c|c|c|c|c|}
\hline \multicolumn{10}{|l|}{ ESA TÁBLÁK } \\
\hline \multicolumn{2}{|l|}{ FIRM } & 2005 & 2006 & 2007 & 2008 & 2009 & 2010 & 2011 & 2012 \\
\hline B1FIRM & B1FIRM & 11536,89 & 12841,86 & 13560,72 & 14390,82 & 13737,95 & 14682,49 & 14682,49 & 14682,49 \\
\hline XGDPNETS11 & b1s11 & 10699,03 & 11907,01 & 12675,15 & 13515,85 & 12756,42 & 13678,02 & 13678,02 & 13678,02 \\
\hline XGDPNETS 12 & $\mathrm{~b} 1 \mathrm{~s} 12$ & 837,87 & 934,84 & 885,58 & 874,97 & 981,53 & 1004,46 & 1004,46 & 1004,46 \\
\hline XGDP-XGDPNET & B1TAX & 3159,11 & 3245,20 & 3634,08 & 3899,54 & 3965,61 & 4132,78 & 0,00 & 0,00 \\
\hline FISIM & Képzett szektor & 3159,11 & 3213,25 & 3634,08 & 3899,54 & 3965,61 & 4132,78 & 4132,78 & 4132,78 \\
\hline -D1FIRM & D1FIRM & 6788,61 & 7296,24 & 8015,25 & 8510,85 & 8218,73 & 8064,27 & 8064,27 & 8064,27 \\
\hline ILABORS11 & d1s11 & 6397,25 & 6856,26 & 7507,88 & 7971,78 & 7686,34 & 7537,27 & 7537,27 & 7537,27 \\
\hline ILABORS12 & $\mathrm{d} 1 \mathrm{~s} 12$ & 391,36 & 439,99 & 507,37 & 539,07 & 532,40 & 526,99 & 526,99 & 526,99 \\
\hline & D2SUM-D3s1 & 3039,65 & 3102,30 & 3491,65 & 3712,66 & 3749,45 & 3991,14 & $-141,64$ & $-141,64$ \\
\hline$-\mathrm{D} 2 \mathrm{sum}$ & D2SUM(ecoline A) & 3478,93 & 3627,53 & 4062,95 & 4247,10 & 4331,43 & 4588,53 & 455,75 & 455,75 \\
\hline D3sum & D3SUM(ecoline Al & 439,28 & 525,23 & 571,30 & 534,44 & 581,98 & 597,39 & 597,39 & 597,39 \\
\hline OTTAXFIRM & OTTAXFIRM & 66,46 & 89,39 & 105,98 & 125,39 & 132,56 & 123,54 & 123,54 & 123,54 \\
\hline B2ANDB3FIRM=B2FIRM & B2ANDB3FIRM & 1642,18 & 2353,92 & 1947,85 & 2041,91 & 1637,21 & 2503,54 & 6636,31 & 6636,31 \\
\hline IMIXS11 & SS11SUM & 4354,63 & 5104,44 & 5203,87 & 5611,79 & 5157,71 & 6165,68 & 6165,68 & 6165,68 \\
\hline IMIXS12 & SS12sum & 446,66 & 494,69 & 378,06 & 329,66 & 445,11 & 470,64 & 470,64 & 470,64 \\
\hline FISIM & Képzett szektor & 0,00 & 0,00 & 0,00 & 0,00 & 0,00 & 0,00 & 4132,78 & 4132,78 \\
\hline & & 4801,29 & 5599,13 & 5581,93 & 5941,45 & 5602,82 & 6636,32 & 10769,09 & 10769,09 \\
\hline D4FIRM & D4FIRM & 2580,90 & 3867,92 & 4844,38 & 5846,05 & 6576,11 & 5762,39 & $-5451,49$ & $-5451,49$ \\
\hline D4S11L & SS11SUM & 848,26 & 1848,72 & 2477,72 & 3124,67 & 3724,06 & 3308,30 & $-1349,62$ & $-1349,62$ \\
\hline D4S12L & SS12SUM & 1732,64 & 2019,20 & 2366,66 & 2721,37 & 2852,05 & 2454,09 & 30,91 & 30,91 \\
\hline -FISIM & Képzett sz. (+!!!) & 0,00 & 0,00 & 0,00 & 0,00 & 0,00 & 0,00 & $-4132,78$ & $-4132,78$ \\
\hline B5FIRM=B2ANDB3FIRM + D4FIRM & B5FIRM & 4223,07 & 6221,84 & 6792,23 & 7887,96 & 8213,32 & 8265,92 & 1184,82 & 1184,82 \\
\hline -D5FIRM & D5FIRM & 457,93 & 554,95 & 700,47 & 694,91 & 577,55 & 328,52 & 507,78 & 507,78 \\
\hline D5S11A & SS11SUM & 337,63 & 426,20 & 582,39 & 601,93 & 500,02 & 266,74 & 323,37 & 323,37 \\
\hline D5S12A & SS12SUM & 120,30 & 128,75 & 118,08 & 92,98 & 77,54 & 61,78 & 184,41 & 184,41 \\
\hline D61FIRM & D61FIRM & 485,95 & 590,65 & 618,83 & 760,64 & 713,21 & 675,14 & 215,07 & 215,07 \\
\hline D61S11L & SS11SUM & 29,19 & 27,64 & 28,56 & 48,90 & 34,82 & 44,03 & 29,99 & 29,99 \\
\hline D61S12L & SS12SUM & 456,76 & 563,01 & 590,28 & 711,74 & 678,39 & 631,11 & 185,07 & 185,07 \\
\hline -D62FIRM & D62FIRM & 119,02 & 127,54 & 148,13 & 192,45 & 186,31 & 179,07 & 179,07 & 179,07 \\
\hline D62S11A & SS11SUM & 29,93 & 28,48 & 30,08 & 51,14 & 37,70 & 46,20 & 48,91 & 48,91 \\
\hline D62S12A & SS12SUM & 89,08 & 99,05 & 118,05 & 141,31 & 148,61 & 132,87 & 130,16 & 130,16 \\
\hline D7FIRM & D7FIRM & 480,61 & 622,95 & 545,49 & 653,13 & 695,93 & 705,07 & $-71,73$ & $-71,73$ \\
\hline D7S11A & SS11SUM & 253,94 & 392,14 & 287,06 & 405,18 & 473,38 & 461,76 & $-68,48$ & $-68,48$ \\
\hline D7S12A & SS12SUM & 226,67 & 230,82 & 258,44 & 247,95 & 222,54 & 243,32 & $-3,25$ & $-3,25$ \\
\hline B6FIRM & B6FIRM & 4612,69 & 6752,96 & 7107,96 & 8414,38 & 8858,59 & 9138,55 & 641,31 & 641,31 \\
\hline B7FIRM & B7FIRM & 4612,69 & 6752,96 & 7107,96 & 8414,38 & 8858,59 & 9138,55 & 641,31 & 641,31 \\
\hline -D8SUM & D8SUM & 367,68 & 463,95 & 472,23 & 570,43 & 529,78 & 498,24 & 498,24 & 498,24 \\
\hline B8FIRM = B7FIRM - D8sum & B8FIRM & 4245,01 & 6289,00 & 6635,73 & 7843,95 & 8328,81 & 8640,31 & 143,07 & 143,07 \\
\hline D9FIRM & D9FIRM & 206,91 & 250,10 & 334,53 & 326,71 & 303,14 & 100,46 & 222,82 & 222,82 \\
\hline D9S11L & & 205,74 & 249,41 & 331,11 & 322,52 & 322,60 & 294,41 & 201,29 & 201,29 \\
\hline D9S12L & & 1,17 & 0,69 & 3,41 & 4,20 & $-19,46$ & $-193,95$ & 21,53 & 21,53 \\
\hline B10FIRM & B10FIRM & 4451,92 & 6539,10 & 6970,25 & 8170,66 & 8631,95 & 8740,77 & 365,89 & 365,89 \\
\hline -XINVBU & XINVBU & 2954,92 & 3012,56 & 3215,19 & 3570,86 & 3119,64 & 2802,57 & 2801,50 & 2750,18 \\
\hline -XDSTCKFIRM & XDSTCKFIRM & 383,72 & 552,74 & 152,86 & 492,03 & $-702,95$ & 108,87 & 564,20 & 612,40 \\
\hline B9FIRM & B9FIRM & 1113,29 & 2973,81 & 3602,21 & 4107,77 & 6215,26 & 5829,34 & $-2999,82$ & $-2996,69$ \\
\hline
\end{tabular}




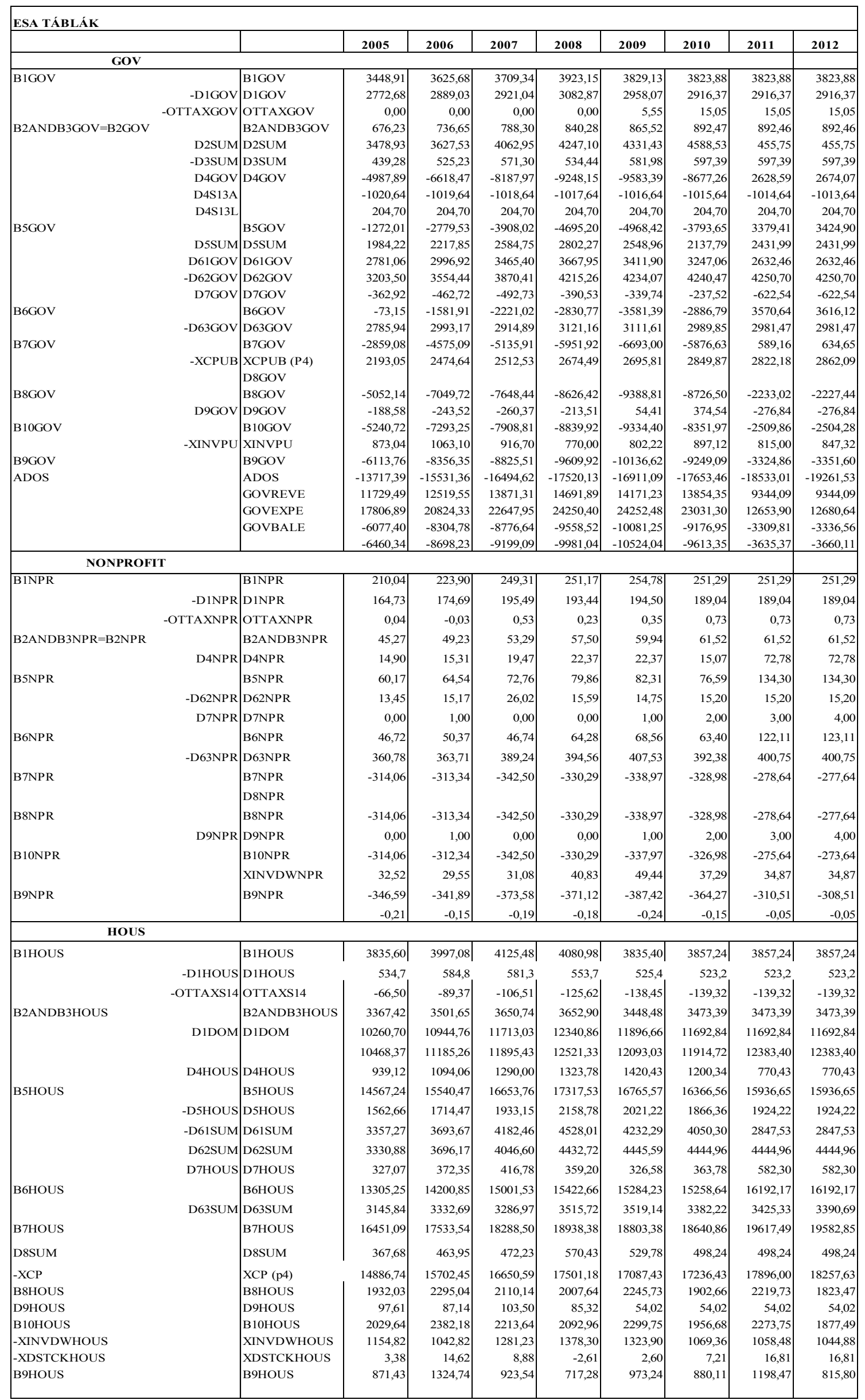




\begin{tabular}{|c|c|c|c|c|c|c|c|c|c|c|}
\hline & & 2005 & 2006 & 2007 & 2008 & 2009 & 2010 & 2011 & 2012 & 2013 \\
\hline \multicolumn{2}{|l|}{ Népgazdaság összesen } & & & & & & & & & \\
\hline $\mathrm{B} 1 \mathrm{DOM}=\mathrm{XGDP}$ & B1DOM & 22018,28 & 23675,85 & 24991,85 & 26545,65 & 25622,87 & 26747,66 & 28080,32 & 29184,14 & 29405,07 \\
\hline -D1SUM & D1SUM & 10260,70 & 10944,76 & 11713,03 & 12340,86 & 11896,66 & 11692,84 & 11692,84 & 11692,84 & 0,00 \\
\hline -D2SUM & D2SUM & 3478,93 & 3627,53 & 4062,95 & 4247,10 & 4331,43 & 4588,53 & 455,75 & 455,75 & 0,00 \\
\hline +D3SUM & D3SUM & 439,28 & 525,23 & 571,30 & 534,44 & 581,98 & 597,39 & 597,39 & 597,39 & 0,00 \\
\hline B2ANDB3DOM = B1DOM - D1SUM - D & B2ANDB3DOM & 8717,93 & 9628,80 & 9787,17 & 10492,13 & 9976,76 & 11063,69 & 16529,12 & 17632,93 & 29405,07 \\
\hline FIRM + GOV $+\mathrm{NPR}+$ HOUS & & 5731,10 & 6641,46 & 6440,18 & 6592,59 & 6011,15 & 6930,91 & 11063,69 & 11063,69 & 0,00 \\
\hline +D1SUM & D1SUM & 10260,70 & 10944,76 & 11713,03 & 12340,86 & 11896,66 & 11692,84 & 11692,84 & 11692,84 & 0,00 \\
\hline$+\mathrm{D} 2 \mathrm{SUM}$ & D2SUM & 3478,93 & 3627,53 & 4062,95 & 4247,10 & 4331,43 & 4588,53 & 455,75 & 455,75 & 0,00 \\
\hline -D3SUM & D3SUM & 439,28 & 525,23 & 571,30 & 534,44 & 581,98 & 597,39 & 597,39 & 597,39 & 0,00 \\
\hline D4DOM & D4DOM & $-1452,98$ & $-1641,19$ & $-2034,13$ & $-2055,96$ & $-1564,48$ & $-1699,46$ & $-1979,70$ & $-1934,21$ & $-1934,21$ \\
\hline \multicolumn{11}{|l|}{$-\mathrm{D} 4 \mathrm{~S} 1 \mathrm{~A}$} \\
\hline D4S1L & & & & & & & & & & \\
\hline $\mathrm{B} 5 \mathrm{DOM}=\mathrm{B} 2 \mathrm{ANDB} 3 \mathrm{DOM}+\mathrm{D} 4 \mathrm{DOM}$ & B5DOM & 20565,31 & 22034,66 & 22957,72 & 24489,69 & 24058,38 & 25048,20 & 26100,62 & 27249,92 & 27470,86 \\
\hline FIRM + GOV + HOUS & & 17518,30 & 18982,78 & 19537,96 & 20510,29 & 20010,47 & 20838,83 & 20500,88 & 20546,37 & 0,00 \\
\hline D7DOM & D7DOM & 444,75 & 532,58 & 469,54 & 621,80 & 682,76 & 831,33 & $-111,97$ & $-111,97$ & 0,00 \\
\hline $\mathrm{B} 6 \mathrm{DOM}=\mathrm{B} 5 \mathrm{DOM}+\mathrm{D} 7 \mathrm{DOM}$ & B6DOM & 21010,06 & 22567,24 & 23427,26 & 25111,49 & 24741,14 & 25879,53 & 25988,65 & 27137,95 & 27470,86 \\
\hline FIRM + GOV + HOUS & & 17891,51 & 19422,25 & 19935,20 & 21070,55 & 20629,99 & 21573,80 & 20526,22 & 20572,71 & 0,00 \\
\hline $\mathrm{B} 7 \mathrm{DOM}=\mathrm{B} 6 \mathrm{DOM}$ & B7DOM & 21010,06 & 22567,24 & 23427,26 & 25111,49 & 24741,14 & 25879,53 & 25988,65 & 27137,95 & 27470,86 \\
\hline FIRM + GOV + HOUS & & 17890,63 & 19398,07 & 19918,04 & 21070,55 & 20629,99 & 21573,80 & 20569,32 & 20581,17 & 0,00 \\
\hline$-\mathrm{XC}$ & $\mathrm{XC}(\mathrm{P} 4)$ & 17079,79 & 18177,09 & 19163,12 & 20175,67 & 19783,24 & 20086,31 & 20718,18 & 21119,71 & 0,00 \\
\hline $\mathrm{B} 8 \mathrm{DOM}=\mathrm{B} 7 \mathrm{DOM}-\mathrm{XC}$ & B8DOM & 3930,27 & 4390,15 & 4264,14 & 4935,83 & 4957,90 & 5793,23 & 5270,47 & 6018,24 & 27470,86 \\
\hline FIRM + GOV + HOUS & & 810,84 & 1220,98 & 754,92 & 894,88 & 846,75 & 1487,49 & $-148,86$ & $-538,54$ & 0,00 \\
\hline D9DOM & D9DOM & 115,94 & 93,71 & 177,66 & 198,53 & 411,57 & 529,01 & 0,00 & 0,00 & 0,00 \\
\hline B10DOM = B8DOM + D9DOM & B10DOM & 4046,20 & 4483,86 & 4441,80 & 5134,35 & 5369,47 & 6322,24 & 5270,47 & 6018,24 & 27470,86 \\
\hline FIRM + GOV + HOUS & & 926,77 & 1315,69 & 932,58 & 1093,41 & 1259,32 & 2018,50 & $-145,86$ & $-534,54$ & 0,00 \\
\hline$-\mathrm{XINV}$ & XINV & 5015,30 & 5148,03 & 5444,19 & 5759,99 & 5295,20 & 4806,33 & 4709,85 & 4677,26 & 4715,63 \\
\hline -XDSTCK & XDSTCK & 387,10 & 567,35 & 161,74 & 489,42 & $-700,35$ & 116,08 & 581,01 & 629,21 & 654,50 \\
\hline \multirow[t]{2}{*}{ B9DOM = B10DOM -XINV-XDSTCK } & B9DOM & $-1356,19$ & $-1231,52$ & $-1164,13$ & $-1115,05$ & 774,62 & 1399,83 & $-20,38$ & 711,77 & 22100,73 \\
\hline & & $-4475,63$ & $-4399,69$ & $-4673,34$ & $-5156,00$ & $-3335,53$ & $-2903,91$ & $-5436,71$ & $-5841,01$ & 0,00 \\
\hline \multicolumn{11}{|l|}{ ROW } \\
\hline $\mathrm{XM}-\mathrm{XX}$ & B1ROW & 463,91 & 216,62 & $-222,80$ & $-120,57$ & $-1244,78$ & $-1738,95$ & $-2071,29$ & $-2166,50$ & $-2071,29$ \\
\hline Külföldi munkajövedelem & D1ROW & $-207,67$ & $-240,50$ & $-182,40$ & $-180,47$ & $-196,37$ & $-221,88$ & $-212,71$ & $-227,01$ & $-227,01$ \\
\hline D4ROW & D4ROW & 1452,98 & 1641,19 & 2034,13 & 2055,96 & 1564,48 & 1699,46 & 1979,70 & 1934,21 & 1934,21 \\
\hline FM. 3. Jövedelmek, egyenleg & \multicolumn{2}{|c|}{ D4row+D4DOM=0 !!! } & & & & & & & & \\
\hline D43S2A & & 0,00 & 0,00 & 0,00 & 0,00 & 0,00 & 0,00 & 0,00 & 0,00 & 0,00 \\
\hline DOLDS2A & & 0,00 & 0,00 & 0,00 & 0,00 & 0,00 & 0,00 & 0,00 & 0,00 & 0,00 \\
\hline B5ROW & B5ROW & 2124,56 & 2098,31 & 1993,73 & 2115,86 & 516,07 & 182,39 & 121,13 & $-5,27$ & 89,94 \\
\hline D7ROW & D7ROW_fm & 69,41 & 79,20 & 126,78 & 149,85 & $-113,48$ & $-111,97$ & $-139,79$ & $-135,81$ & $-135,81$ \\
\hline d7row $=(-1) \mathrm{d} 7 \mathrm{dom}$ & D7ROW & $-444,75$ & $-532,58$ & $-469,54$ & $-621,80$ & $-682,76$ & $-831,33$ & 111,97 & 111,97 & 0,00 \\
\hline \multicolumn{11}{|l|}{ FM. 4. Viszonzatlan átutalások, egyenleg } \\
\hline B6ROW & B6ROW_fm & 1986,29 & 1937,01 & 1938,11 & 2085,23 & 206,22 & $-151,45$ & $-231,38$ & $-368,09$ & $-272,88$ \\
\hline B6ROW_UJ & B6ROW & 1472,13 & 1325,23 & 1341,79 & 1313,58 & $-363,05$ & $-870,82$ & 20,38 & $-120,32$ & $-137,07$ \\
\hline folyó fizetési mérleg egyenlege & & $-434,56$ & $-433,56$ & $-432,56$ & $-431,56$ & $-430,56$ & $-429,56$ & $-428,56$ & $-427,56$ & $-426,56$ \\
\hline D9ROW & D9ROW_fm & $-149,13$ & $-180,98$ & $-177,42$ & $-261,97$ & $-307,34$ & $-482,53$ & $-607,36$ & $-605,44$ & $-605,44$ \\
\hline D9ROW=(-1)D9DOM & D9ROW & $-115,94$ & $-93,71$ & $-177,66$ & $-198,53$ & $-411,57$ & $-529,01$ & 0,00 & 0,00 & 0,00 \\
\hline tökemérleg egyenlege & & 30,56 & 31,56 & 32,56 & 33,56 & 34,56 & 35,56 & 36,56 & 37,56 & 38,56 \\
\hline B10ROW & B10ROW & 1837,16 & 1756,03 & 1760,69 & 1823,26 & $-101,12$ & $-633,99$ & $-838,74$ & $-973,53$ & $-878,32$ \\
\hline \multirow[t]{2}{*}{ B9ROW } & B9ROW_fm & 1837,16 & 1756,03 & 1760,69 & 1823,26 & $-101,12$ & $-633,99$ & $-838,74$ & $-973,53$ & $-878,32$ \\
\hline & B9ROW & 1356,20 & 1231,52 & 1164,13 & 1115,05 & $-774,62$ & $-1399,83$ & 20,38 & $-120,32$ & $-137,07$ \\
\hline B9ROWEU & B9ROWEU & 9067,91 & 8667,47 & 8690,47 & 8999,31 & $-499,10$ & $-3129,25$ & $-4139,87$ & $-4805,19$ & $-4335,24$ \\
\hline \multirow[t]{2}{*}{ B9ROWDOL } & B9ROWDOL & 32924,00 & 31470,07 & 31553,58 & 32674,92 & $-1812,15$ & $-11361,76$ & $-15031,15$ & $-17446,79$ & $-15740,48$ \\
\hline & B9_KUL & 480,96 & 524,51 & 596,56 & 708,21 & 673,50 & 765,84 & $-859,12$ & $-853,22$ & $-741,25$ \\
\hline B5ROW & B5ROW & 1916,89 & 1857,82 & 1811,33 & 1935,38 & 319,71 & $-39,49$ & $-91,58$ & $-232,28$ & $-137,07$ \\
\hline B6ROW & B6ROW & 1986,29 & 1937,01 & 1938,11 & 2085,23 & 206,22 & $-151,45$ & $-231,38$ & $-368,09$ & $-272,88$ \\
\hline B7ROW & B7ROW & 1986,29 & 1937,01 & 1938,11 & 2085,23 & 206,22 & $-151,45$ & $-231,38$ & $-368,09$ & $-272,88$ \\
\hline B8ROW & B8ROW & 1986,29 & 1937,01 & 1938,11 & 2085,23 & 206,22 & $-151,45$ & $-231,38$ & $-368,09$ & $-272,88$ \\
\hline Fogyasztói árváltozás & cpil & 1,00 & 1,04 & 1,12 & 1,19 & 1,24 & 1,30 & 1,35 & 1,39 & 1,35 \\
\hline Termelöi árindex(Ft) & ppiFt1 & 1,15 & 1,22 & 1,22 & 1,28 & 1,34 & 1,40 & 1,40 & 1,40 & 1,40 \\
\hline B1GOVQGDP & & 2326,4815 & 2326,4815 & 3709,338 & 3923,152 & 3829,13 & 3823,879 & 3759,42 & 3653,997 & 3656,085 \\
\hline B1HOUSQGDP & & 2828,9698 & 2828,9698 & NA & NA & NA & NA & 3328,958 & 3296,561 & 3322,338 \\
\hline
\end{tabular}

